\title{
Flow Modification in the Nation's Streams and Rivers
}
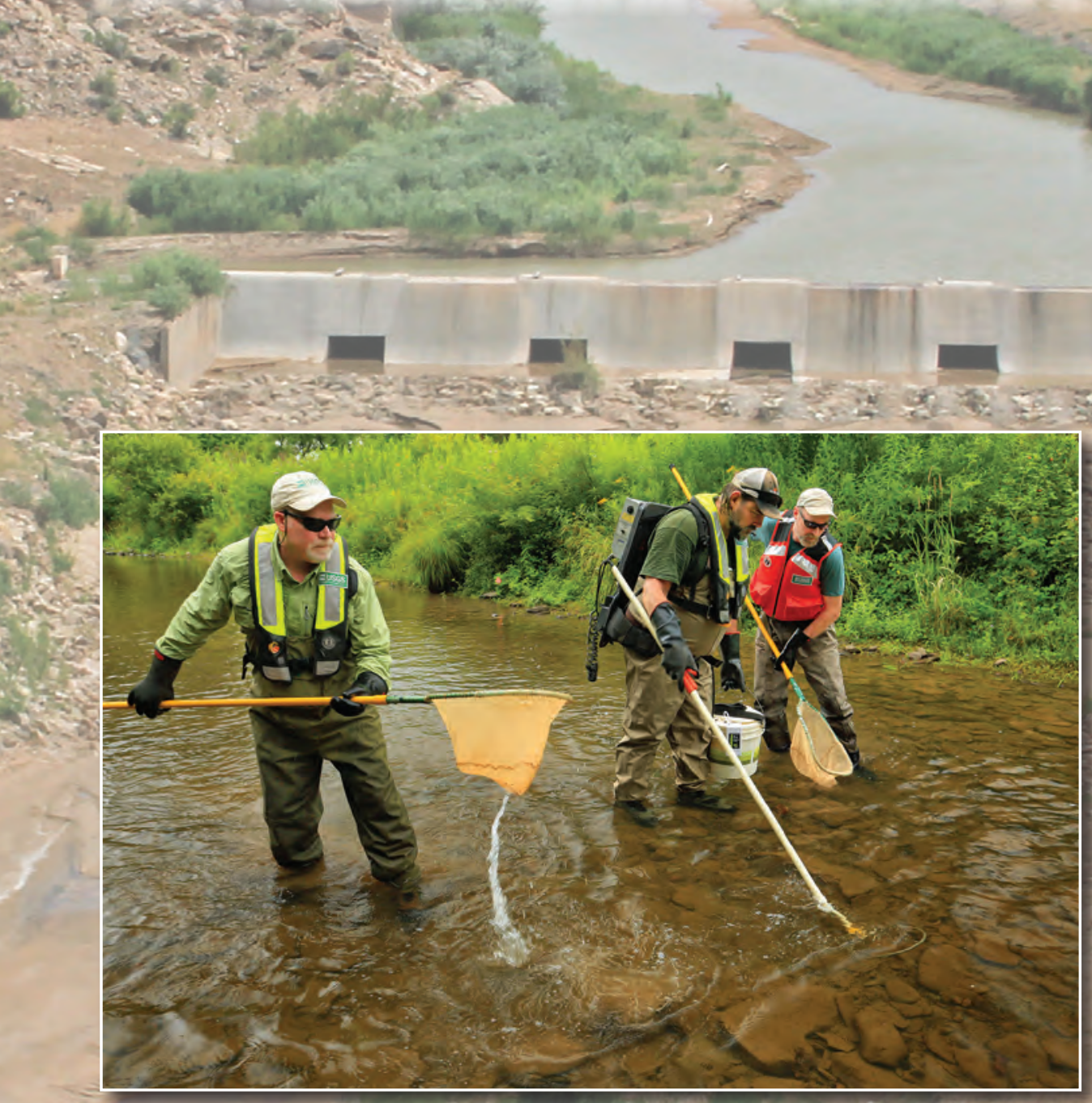

National Water-Quality Program

National Water-Quality Assessment Project

\section{Circular 1461}

U.S. Department of the Interior

U.S. Geological Survey 
Cover. Upper left photograph: U.S. Geological Survey crew electrofishing in Nanticoke Creek, New York. Upper right photograph: Etheostoma caeruleum (rainbow darter) from Hester Creek, Alabama. Lower left photograph: Calopteryx maculata (ebony jewelwing) near Gola Creek, Georgia. Background photograph: Diversion dam on a southern Utah stream. All photographs by Alan Cressler, U.S. Geological Survey.

Facing page. View of the Trinity River, California. Photograph by Sam Camp, used with permission. 


\section{The Quality of Our Nation's Waters}

\section{Flow Modification in the Nation's Streams and Rivers}

By Daren M. Carlisle, David M. Wolock, Christopher P. Konrad, Gregory J. McCabe, Ken Eng, Theodore E. Grantham, and Barbara Mahler

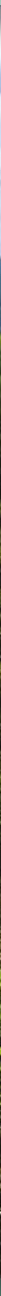

National Water-Quality Program

National Water-Quality Assessment Project

Circular 1461

U.S. Department of the Interior

U.S. Geological Survey 


\title{
U.S. Department of the Interior DAVID BERNHARDT, Secretary
}

\author{
U.S. Geological Survey \\ James F. Reilly II, Director
}

U.S. Geological Survey, Reston, Virginia: 2019

For more information on the USGS - the Federal source for science about the Earth, its natural and living resources, natural hazards, and the environment-visit https://www.usgs.gov or call 1-888-ASK-USGS.

For an overview of USGS information products, including maps, imagery, and publications, visit https://store.usgs.gov.

Any use of trade, firm, or product names is for descriptive purposes only and does not imply endorsement by the U.S. Government.

Although this information product, for the most part, is in the public domain, it also may contain copyrighted materials as noted in the text. Permission to reproduce copyrighted items must be secured from the copyright owner.

Suggested citation:

Carlisle, D.M., Wolock, D.M., Konrad, C.P., McCabe, G.J., Eng, K., Grantham, T.E., and Mahler, B., 2019, Flow modification in the Nation's streams and rivers: U.S. Geological Survey Circular 1461, 75 p., https://doi.org/10.3133/cir1461.

ISSN 1067-084X (print)

ISSN 2330-5703 (online)

ISBN 978-1-4113-4340-5 


\section{Foreword}

Sustaining the quality of the Nation's water resources and the health of our diverse ecosystems depends on the availability of sound water-resources data and information to develop effective, science-based policies. Effective management of water resources also brings more certainty and efficiency to important economic sectors. Taken together, these actions lead to immediate and long-term economic, social, and environmental benefits that make a difference to the lives of the almost 400 million people projected to live in the United States by 2050.

In 1991, Congress established the National Water-Quality Assessment (NAWQA) to address where, when, why, and how the Nation's water quality has changed, or is likely to change in the future, in response to human activities and natural factors. Since then, NAWQA has been a leading source of scientific data and knowledge used by national, regional, State, and local agencies to develop science-based policies and management strategies to improve and protect water resources used for drinking water, recreation, irrigation, energy development, and ecosystem needs. Plans for the third decade of NAWQA address priority water-quality issues and science needs identified by NAWQA stakeholders, such as the Advisory Committee on Water Information and the National Research Council, and are designed to meet increasing challenges related to population growth, increasing needs for clean water, and changing land-use and weather patterns.

Natural patterns of streamflow are critical in supporting the diversity of life and ecological benefits that streams and rivers provide to society. Despite the importance of natural streamflows, there has been no comprehensive national assessment of how natural streamflows have been modified by human activities such as land and water management. In addition, because streamflows are so tightly coupled with precipitation, trends in precipitation and air temperature over the last half century have likely had major impacts on streamflow in some parts of the Nation. This report addresses how human-caused modifications to streamflow affect aquatic life using data compiled from the U.S. Geological Survey and U.S. Environmental Protection Agency collected at more than 7,000 U.S. Geological Survey streamgaging sites. All NAWQA reports are available online at https://usgs.gov/nawqa/.

We hope this publication will provide you with insights and information to meet your waterresource needs and will foster increased citizen awareness and involvement in the protection and restoration of our Nation's waters. The information in this report is intended primarily for those interested or involved in resource management and protection, conservation, regulation, and policymaking at the regional and national levels.

Dr. Donald W. Cline

Associate Director for Water

U.S. Geological Survey 



\section{Acknowledgments}

The assistance of Richard Mitchell (U.S. Environmental Protection Agency) and other personnel associated with the National Rivers and Streams Assessment is gratefully acknowledged. The reviews of Belize Lane (Utah State University), Michael Miller (Wisconsin Department of Natural Resources), Jeannette Howard (The Nature Conservancy), Julie Zimmerman (The Nature Conservancy), Lisa Perras Gordon (U.S. Environmental Protection Agency), Robert Holmes (California Department of Fish and Wildlife), and David Weedman (Arizona Game and Fish Department) were instrumental towards improving this report.

The authors wish to thank the U.S. Geological Survey hydrologic technicians and data managers, whose dedication and vigilance over many decades made this national synthesis possible. 


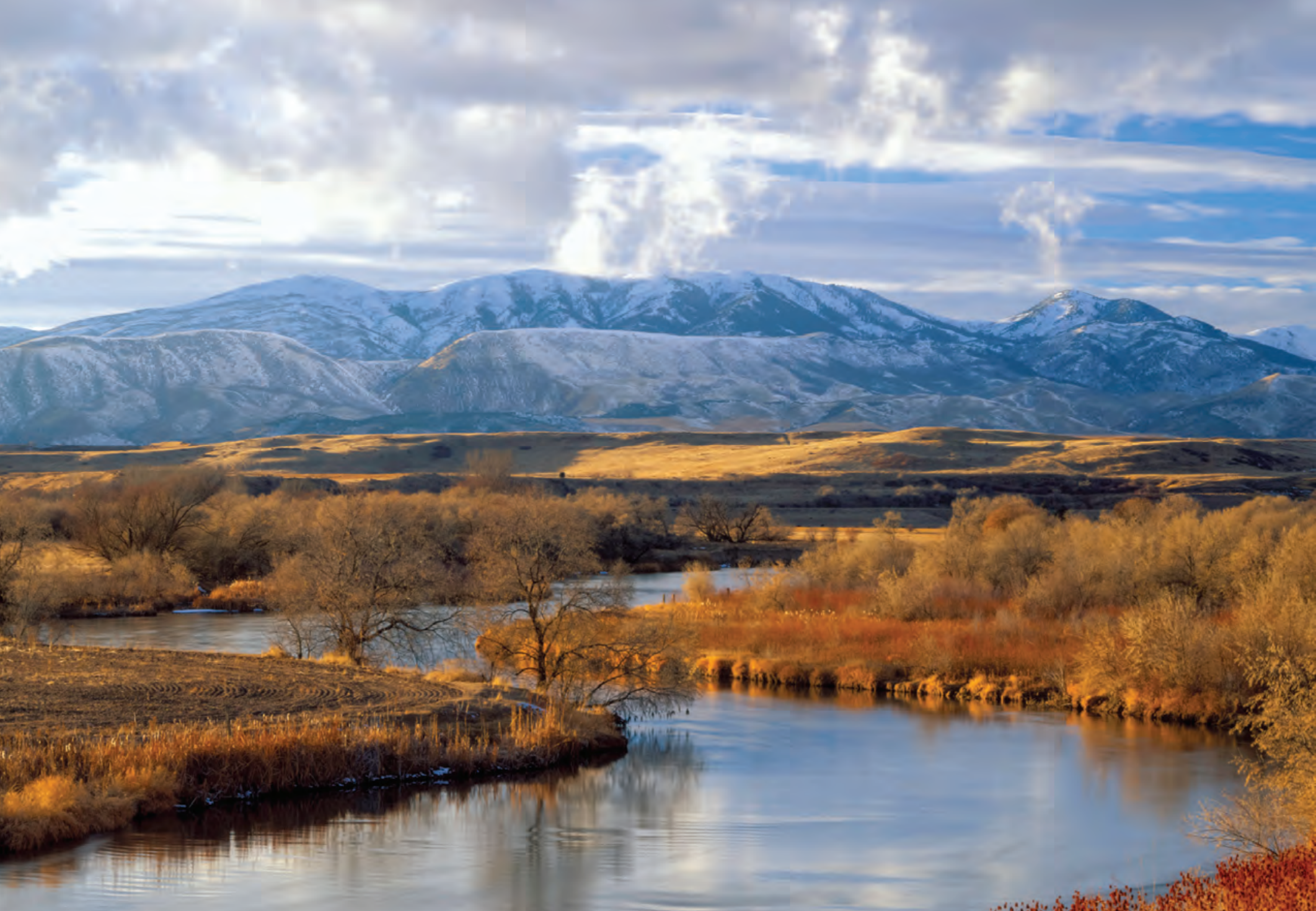




\section{Contents}

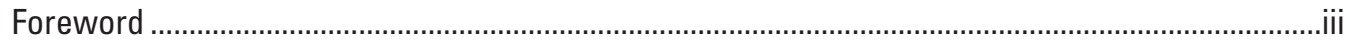

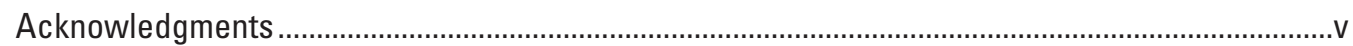

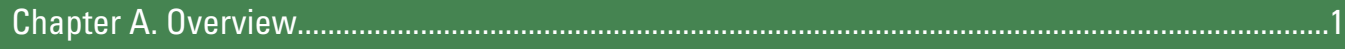

The Natural Patterns of Flowing Water Are Essential to the Health of Streams and

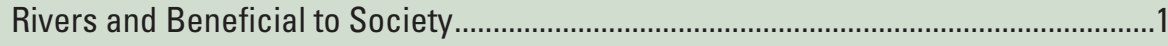

Human-Caused Modification of Natural Flows - A National Assessment................................2

Land and Water Management Have Modified Flow in the Nation's Streams and Rivers ........2

Streamflows Are Highly Sensitive to Climatic Variation and Change .......................................2

Modified Streamflows Are Associated with Ecosystem Deterioration ....................................2

Case Studies Indicate There Are Viable Management Options for Balancing Water

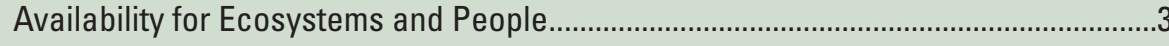

Where Does Streamflow Modification Influence Biological Diversity? .....................................5

Chapter B. National Assessment of Streamflow Modification ...........................................................

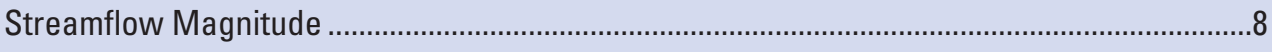

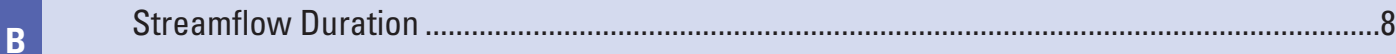

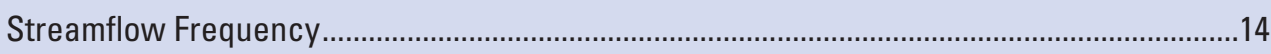

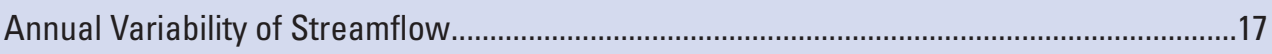

Daily Flow Fluctuation ...........................................................................................................20

Chapter C. Streamflow Modification Associated with Land and Water Management....................23

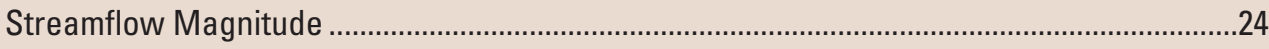

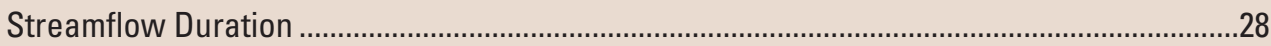

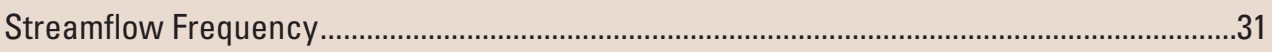

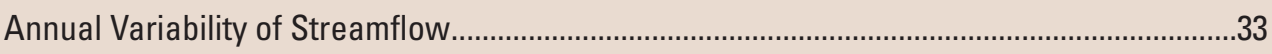

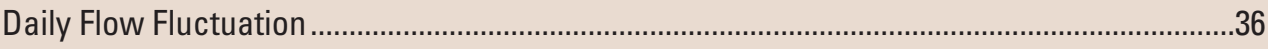

Chapter D. Streamflow Modification and Climate ...........................................................................39

Climate-Related Trends at Reference Sites, 1955-2014 .....................................................42

D Climate Compared to Land and Water Management, 1980-2014 ….........................................46

Magnitude, Frequency, and Duration of Low Flows ...................................................48

Magnitude, Frequency, and Duration of High Flows..................................................48

Chapter E. Ecological Consequences of Streamflow Modification ................................................49

Ecological Responses to Modification of Low-Flow Magnitude ...............................................51

Ecological Responses to Modification of High-Flow Magnitude ............................................52

Ecological Responses to Modification of High-Flow Duration ...............................................54

Ecological Responses to Modification of Low-Flow Frequency................................................57

Ecological Responses to Modified High-Flow Frequency ..........................................................58

Ecological Responses to Modified Annual Variability of Flows................................................59

Ecological Responses to Modified Daily Flow Fluctuation .........................................................62

Chapter F. Managing Modified Streamflows ..............................................................................64

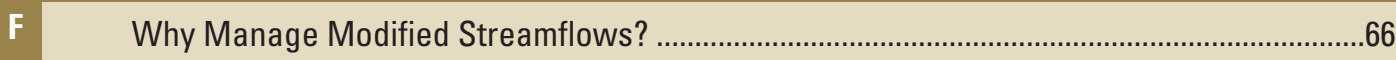

Approaches for Managing Streamflow Modific ation............................................................67

References Cited................................................................................................................. 


\section{Sidebars}

How Big Data Can Help Improve the Nation's Waterways_An Example from California ...............6

How Data4Rivers Works

The Big Data Difference

How Was Streamflow Characterized and Assessed? ...................................................................

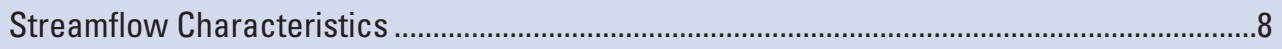

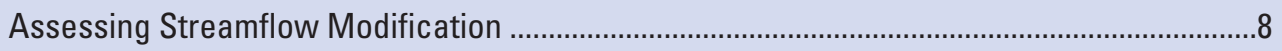

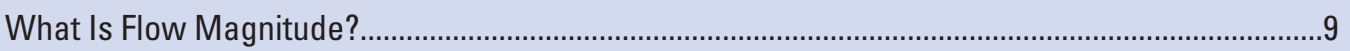

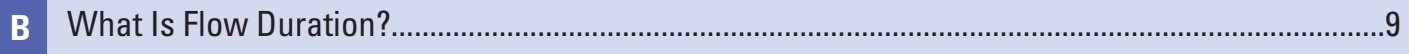

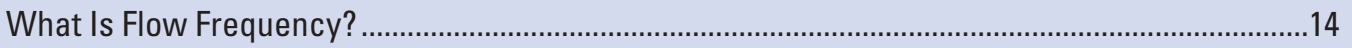

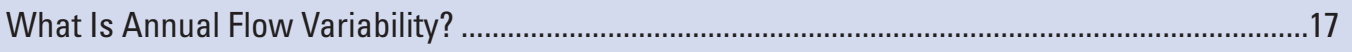

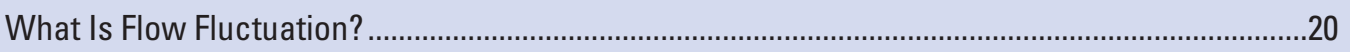

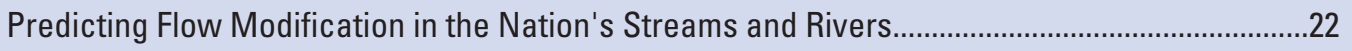

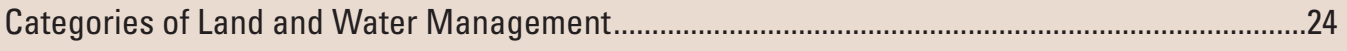

Urbanization Transformed a Naturally Intermittent Stream into a Perennial One...........................26

Many Dams Are Constructed Primarily for Flood Control and Therefore Have Dramatic

Effects on the Magnitude, Frequency, and Duration of High Flows

Groundwater Pumping and Drought Have Caused Low Flows to Become More Frequent and Last Longer in a Western Plains Stream ..................................................................29

C Reservoir Operations Commonly Reduce the Duration of Low Flows in Downstream Rivers........30

Local Differences in the Way Watersheds Urbanize Can Lead to Divergent Effects on

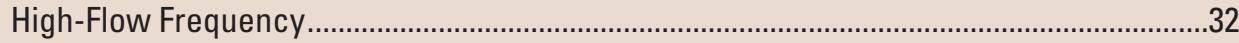

Reservoirs Commonly Reduce the Annual Variation of High Flows ............................................34

Reservoir Management Increases the Annual Variation of Low Flows .........................................35

Land- and Water-Management Practices Increase Daily Flow Fluctuation of Streamflow............37

Land and Water Management Modify the Timing of Low and High Flows ......................................38

Recent Changes in Streamflow in a Historical Context ..............................................................41

The Timing of High Flows is Changing Due to Climate ..............................................................

D Year-to-Year Fluctuations in Streamflow Make it Difficult to Discern Underlying

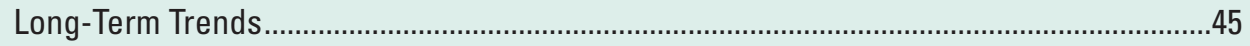

High Flows in Spring are Becoming More Rare in Towanda Creek, Pennsylvania ...........................46

Predicting the Ecological Consequences of Modified Streamflow ................................................50

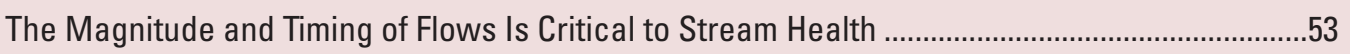

High Flows During Spring May be Universally Important to Stream Health.....................................55

When Streamflow Magnitude and Duration are Modified, Water Quality and Other

Physical Conditions Change Too.

Health of Stream Invertebrates in the Sierra Nevada Mountains Related to Annual

Variability of High Flows

Dam Operations Adjusted to Mitigate the Ecological Consequences of

Streamflow Fluctuation 


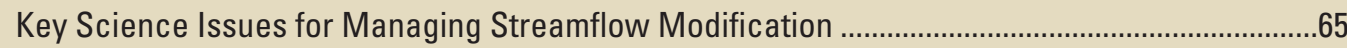

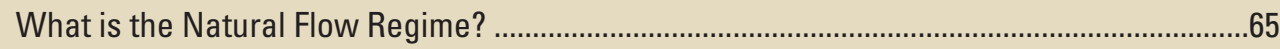

Can a Natural Flow Regime be Adequately Characterized by a Limited Set of

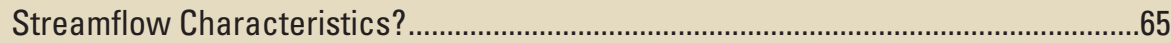

Will the Ecosystem Respond to Streamflow Management? ....................................................65

Reservoir Operations on the Trinity River were Modified to Restore More Natural

Streamflows to Benefit Salmon Populations .......................................................................68

Managing High Flows in the Chesapeake Bay Watershed is a Tool to Improve

Water Quality

Managing Low Flows in the Delaware River Protects Endangered Species and

Improves Water Quality.

Dam Modification and Barging Used to Maintain Salmon Populations in the

Columbia River

\section{Figures}

A1. Map showing efforts to manage land and water have modified the natural patterns of streamflow of an estimated 1.2 million miles - more than one-third - of the

Nation's streams and rivers.

A2. Map showing 599 long-term streamgaging sites where land- and water-use changes have been minimal since 1955

A3. Map showing in every region assessed by the U.S. Geological Survey, reduced diversity of invertebrate or fish communities was associated with modification of natural attributes of streamflow.

B1. Map showing regional summaries of the modification of low-flow magnitude, categorized as being higher, lower, or unmodified relative to natural conditions

B2. Map showing regional summaries of the modification of high-flow magnitude, categorized as being higher, lower, or unmodified relative to natural conditions ..........11

B3. Map showing regional summaries of the modification of low-flow duration, categorized as being longer, shorter, or unmodified relative to natural conditions.

B4. Map showing regional summaries of the modification of high-flow duration, categorized as being longer, shorter, or unmodified relative to natural conditions........13

B5. Map showing regional summaries of the modification of low-flow frequency, categorized as being increased, decreased, or unmodified relative to natural conditions.

B6. Map showing regional summaries of the modification of high-flow frequency, categorized as being increased, decreased, or unmodified relative to natural conditions.

B7. Map showing regional summaries of the modification of low-flow variability, categorized as being increased, decreased, or unmodified relative to natural conditions. 
B8. Map showing regional summaries of the modification of high-flow variability, categorized as being increased, decreased, or unmodified relative to natural conditions

B9. Map showing regional summaries of the modification of daily flow fluctuation, categorized as being increased, decreased, or unmodified relative to natural conditions.

C1. Graphs showing how streamflow magnitude was modified in relation to land and water management.

C2. Graphs showing how streamflow duration was modified in relation to land and water management

C3. Graphs showing how streamflow frequency was modified in relation to land and water management

C4. Graphs showing how annual variability of streamflow was modified in relation to land and water management

C5. Graph showing how daily flow fluctuation was modified in relation to land and water management

D1. Map showing where climate-induced changes in streamflow characteristics were evaluated

D2. Maps showing regional patterns in the climate-induced trends in streamflow characteristics from 1955 to 2014

D3. Figure showing the relative effects of climate versus land and water management on streamflow modification from 1980 to 2014

E1. Graphs showing modification of low-flow magnitude is predicted to impair invertebrate and fish communities in several regions

E2. Graphs showing modification of high-flow magnitude is predicted to impair invertebrate and fish communities in several regions

E3. Graphs showing modification of high-flow duration is predicted to impair invertebrate and fish communities in several regions

E4. Graphs showing modification of low-flow frequency is predicted to impair invertebrate and fish communities in two regions

E5. Graphs showing modification of high-flow frequency is predicted to impair invertebrate and fish communities in several regions

E6. Graphs showing modification of low-flow variability is predicted to impair invertebrate and fish communities in two regions

E7. Graphs showing modification of high-flow variability is predicted to impair invertebrate and fish communities in several regions

E8. Graphs showing modification of daily flow fluctuations is predicted to impair invertebrate and fish communities in several regions 


\section{Conversion Factors}

U.S. customary units to International System of Units

\begin{tabular}{lcl}
\hline \multicolumn{1}{c}{ Multiply } & By & \multicolumn{1}{c}{ To obtain } \\
\hline mile $(\mathrm{mi})$ & Length & kilometer $(\mathrm{km})$ \\
\hline & 1.609 & \\
\hline square ${\mathrm{mile}\left(\mathrm{mi}^{2}\right)}^{\prime}$ & Area & hectare $(\mathrm{ha})$ \\
square $\mathrm{mile}\left(\mathrm{mi}^{2}\right)$ & 259.0 & square kilometer $\left(\mathrm{km}^{2}\right)$ \\
\hline & 2.590 & \\
\hline cubic foot per second $(\mathrm{ft} / \mathrm{s})$ & Flow rate & cubic meter per second $\left(\mathrm{m}^{3} / \mathrm{s}\right)$ \\
gallon per minute $(\mathrm{gal} / \mathrm{min})$ & 0.02832 & liter per second $(\mathrm{L} / \mathrm{s})$ \\
\hline
\end{tabular}

Temperature in degrees Celsius $\left({ }^{\circ} \mathrm{C}\right)$ may be converted to degrees Fahrenheit $\left({ }^{\circ} \mathrm{F}\right)$ as

$$
{ }^{\circ} \mathrm{F}=\left(1.8 \times{ }^{\circ} \mathrm{C}\right)+32 \text {. }
$$

\section{Abbreviations}

NAWQA National Water-Quality Assessment

USGS U.S. Geological Survey 


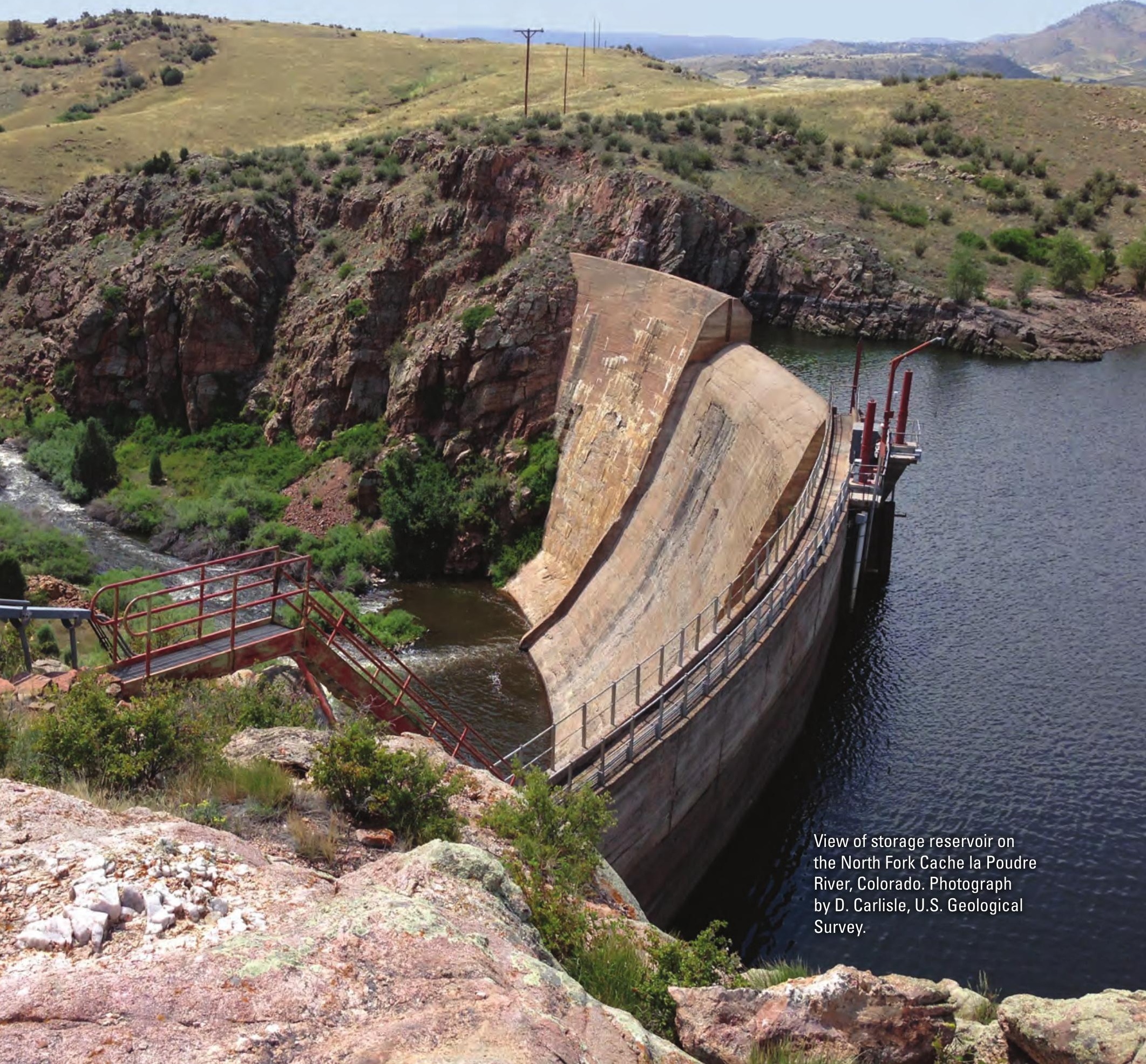




\section{Flow Modification in the Nation's Streams and Rivers}

By Daren M. Carlisle,' David M. Wolock,' Christopher P. Konrad,' Gregory J. McCabe, ${ }^{1}$ Ken Eng, ${ }^{1}$ Theodore E. Grantham, ${ }^{2}$ and Barbara Mahler ${ }^{1}$

\section{Chapter A. Overview}

\section{The Natural Patterns of Flowing Water Are Essential to the Health of Streams and Rivers and Beneficial to Society}

Streams and rivers are dynamic features of the landscape, constantly moving and ever changing. Their flowing waters support diverse ecosystems and provide precious water for many of society's needs. The ability of streams and rivers to provide these important services depends upon the many characteristics of flow, such as the magnitude (flow rate in volume per time, such as gallons per minute), the duration (length of time a specific flow magnitude persists), and the frequency (how often a specific flow magnitude occurs). For example, the availability of water for wildlife and irrigation use requires sufficient flow magnitude during specific seasons. Other characteristics of flow are important as well, including the time of year when high flows or low flows occur and how much flows change from year to year and from day to day.

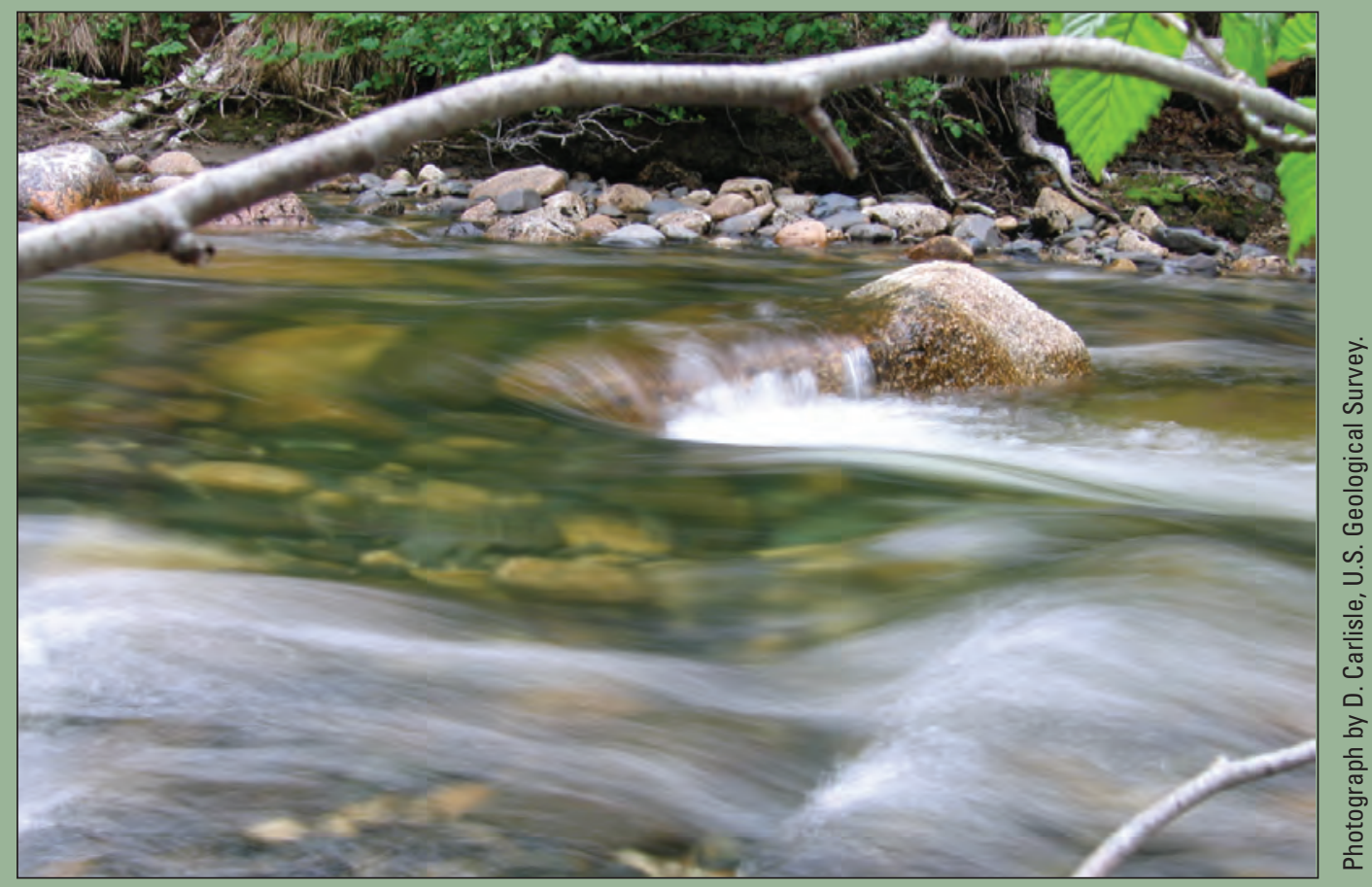

The flowing waters of streams and rivers support diverse ecosystems and provide precious water for many of society's needs.

${ }^{1}$ U.S. Geological Survey.

${ }^{2}$ University of California, Berkeley. 


\section{Human-Caused Modification of Natural Flows-A National Assessment}

This report summarizes a national assessment of flowing waters conducted by the U.S. Geological Survey's (USGS) National Water-Quality Assessment (NAWQA) Project and addresses several pressing questions about the modification of natural flows in streams and rivers. In this report, we first summarize how and where natural flows have been modified by land and water management. Second, we describe how natural flows have been affected by climate changes since 1955, and how those effects compare to those from land and water management. Third, we provide estimates of the flows required to maintain ecological health of stream and river ecosystems. Finally, we present case studies that illustrate management options for balancing the water needs of people and ecosystems. This assessment is based on the integration, modeling, and synthesis of monitoring data collected by the USGS and the U.S. Environmental Protection Agency at more than 7,000 streams and rivers across the conterminous United States.

\section{Land and Water Management Have Modified Flow in the Nation's Streams and Rivers}

Flow in many of the Nation's streams and rivers is often different from what it would be under natural conditions. At more than 3,000 streamgages assessed by the U.S. Geological Survey (USGS), low flows are more frequent, are of shorter duration, and vary less from one year to the next than they would naturally. In addition, high flows have been reduced in magnitude, are of shorter duration, are less frequent, and vary less from one year to the next than they would naturally. Other characteristics of natural flows also have been modified.

The primary causes of modified flows are land- and water-management practices. Land management such as urbanization can modify streamflows in indirect ways because it changes the delivery of precipitation across the landscape to the stream. For example, impermeable surfaces, such as roads and parking lots, prevent rainfall from infiltrating into the ground and being stored as groundwater and instead, rapidly deliver the water to streams and rivers, which can cause excessively high — and sometimes damaging — flows. Water management aimed at flood control, water storage, water transfers, and groundwater pumping is designed to protect life and property and make water available for human needs such as drinking and irrigation. These practices modify natural streamflows in predictable ways, but often these effects vary from region to region.

Estimates from data collected at thousands of streamgaging sites suggest that, collectively, our management of land and water has led to modified flows in 1.2 million miles (mi) - more than one-third — of the Nation's streams and rivers. This information provides a national perspective on the extent to which natural patterns of streamflows may be unavailable for ecosystems because of land- and water-management practices (fig. A1).

\section{Streamflows Are Highly Sensitive to Climatic Variation and Change}

The enormous dependence of streamflow on precipitation and air temperature raises two important questions regarding the effects of climate variation and change on aquatic ecosystems: How has streamflow been affected by recent changes in climate? And how do the changes in streamflow caused by changes in climate compare to those caused by land and water management?

How has streamflow been affected by recent changes in climate? - Over the last 60 years (1955-2014), climatic trends have caused a change of 50 percent or more in one or more streamflow attributes at two-thirds of streamgaging sites (fig. A2). These findings indicate that long-term land and water management will benefit from understanding the trajectories of climate-induced changes to streamflows.

How do the effects of climate-related changes compare to changes in streamflow caused by land and water management?-Land- and water-management practices have exerted a stronger effect on streamflow than climate has in recent decades. When compared to changes in streamflow caused by land and water management over the last 30 years (1980-2014), climate-induced changes are minor. However, this comparison is limited to the recent (1980-2014) period for which information on land and water management is most complete - the relative importance of climate would likely be greater if comparisons were made over longer periods.

\section{Modified Streamflows Are Associated with Ecosystem Deterioration}

Many aquatic species have life histories that are harmonized with natural seasonal patterns of streamflow. In addition, natural patterns of streamflow maintain habitats that are critical to species survival. Consequently, many species are unable to persist, and the health of the ecosystem may decline when streamflow characteristics become increasingly different from natural conditions.

In every region assessed by the USGS, streamflow modification was associated with reduced ecological health, as indicated by two biological communities - invertebrates and fish (fig. A3). Biological communities were increasingly likely to be impaired (defined as having lost a statistically significant number of species) in streams with flows most different from natural conditions. Many characteristics of streamflow, when modified, were related to impaired biological communities, including the magnitude, duration, frequency, annual variability (year-to-year fluctuation of flows), and daily flow fluctuations. Importantly, these findings represent only a subset of the 


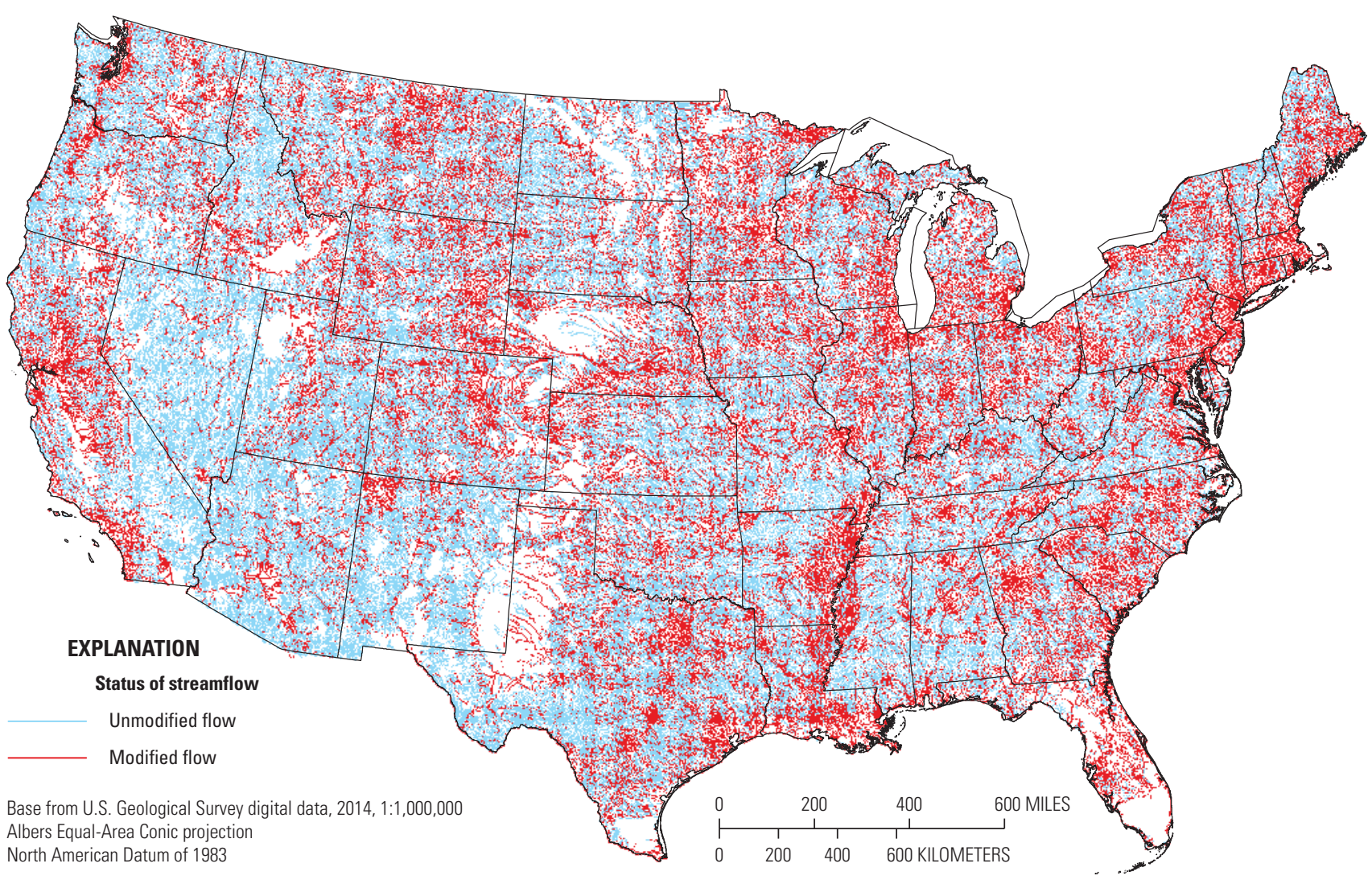

Figure A1. Our efforts to manage land and water have modified the natural patterns of streamflow of an estimated 1.2 million miles-more than one-third — of the Nation's streams and rivers. In this map of the entire network of streams and rivers in the conterminous United States, streams with modified flow are shown in red and streams with natural flows are shown in blue.

streamflow attributes that are important to maintaining stream health because other aspects of stream ecosystems - such as plant communities and ecological processes-were not assessed.

\section{Case Studies Indicate There Are Viable Management Options for Balancing Water Availability for Ecosystems and People}

Streamflow modification can impair more than ecosystem health - it can interfere with human needs for water and can limit land use along river corridors. For example, stream diversions may limit the water available downstream for other water users and public resources (California Supreme Court, 1983). Unnaturally high magnitudes caused by impervious cover in urban areas increase the frequency and extent of flooding, which can damage roads, bridges, and other infrastructure (Konrad, 2003; National Research Council, 2008). Managing streamflow modification therefore protects people and the ways we use water, in addition to protecting ecosystems.
There are a range of approaches used to manage streamflow modification to fit stakeholder goals. The scope of management can be limited to key streamflow characteristics such as low-flow magnitude or can be more comprehensive by addressing the overall flow regime of a river-the combination of streamflow magnitude, variability, and timing. Importantly, all approaches require the scientific understanding gained from monitoring and study.

Approach 1. Protect or restore multiple characteristics of natural streamflows. - This approach involves the protection of multiple characteristics, such as low-flow and high-flow magnitudes, duration, and frequency. In its most comprehensive implementation, this approach strives to protect all characteristics of the natural flow regime. The premise of this approach is that natural characteristics of streamflow will sustain the widest array of species and ecological health.

Approach 2. Protect or restore specific characteristics of natural streamflows.-This approach involves the protection or restoration of a specific streamflow attribute (for example, high-flow duration) and is based on the theory that the key attribute is necessary for ecosystem health or critical life stages of key species. A streamflow characteristic may serve as 


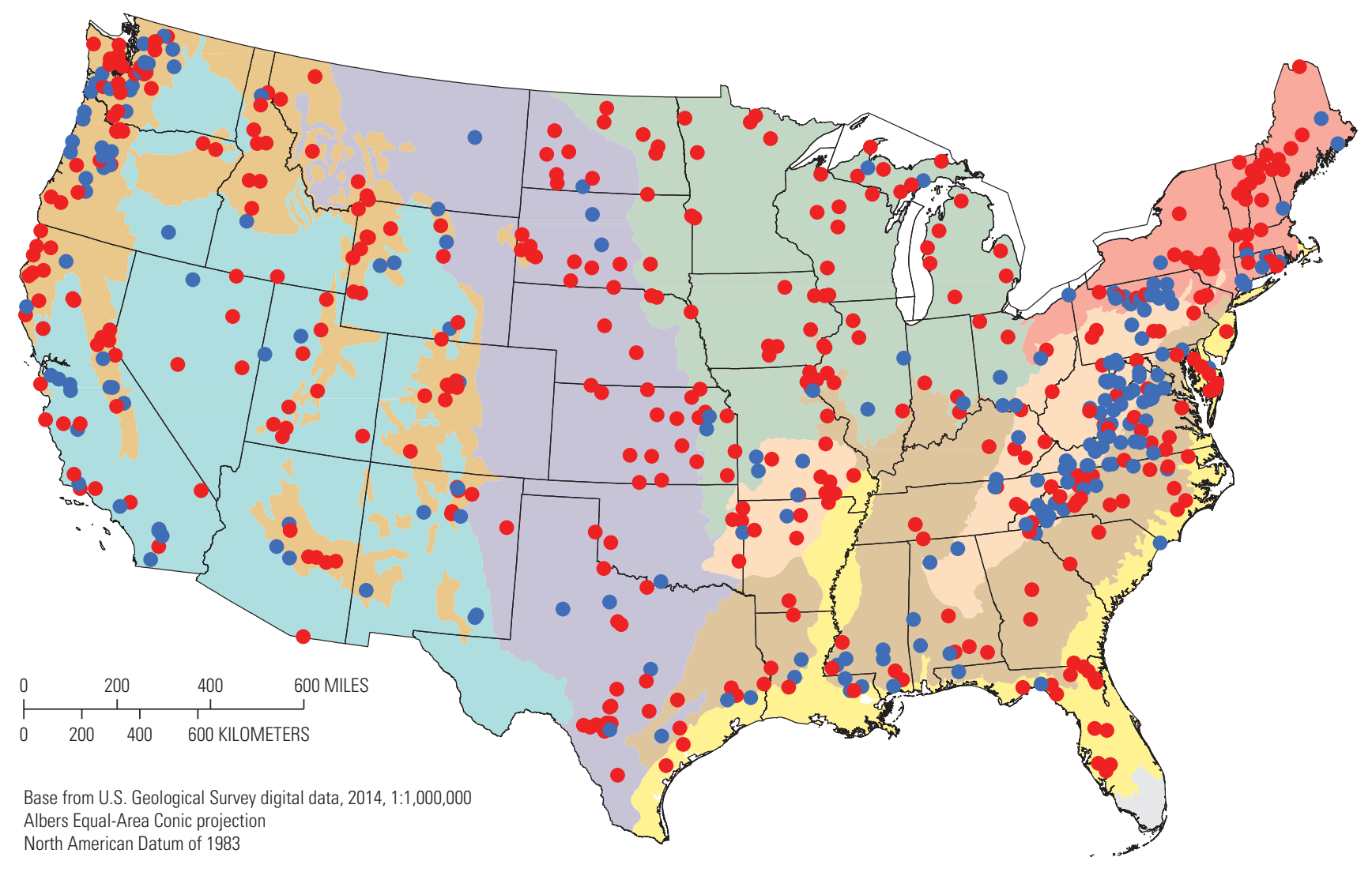
Albers Equal-Area Conic projection
North American Datum of 1983

EXPLANATION
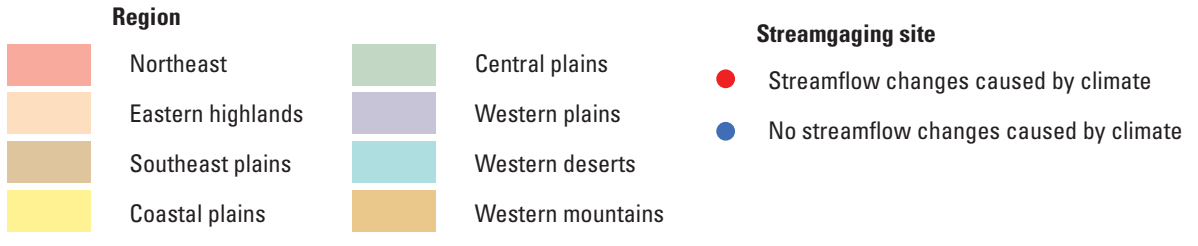

Figure A2. At 599 long-term streamgaging sites where land- and water-use changes have been minimal since 1955, climate has caused changes to streamflow at two-thirds of the sites (red dots) and has not caused changes at one-third of the sites (blue dots).

the standard to assess the performance of management actions or even be used in an adaptive management cycle such as the following: manage flow characteristic - monitor outcomerevise flow management.

Approach 3. Manage streamflow for specific outcomes.This approach represents active ecosystem management typically required when other goals such as water supply or energy production are less flexible. Often the specific management outcome is driven by specific needs, such as the life stage of an endangered species.

Approach 4. Manage other elements of the ecosystem to mitigate/compensate for effects of modified flows.-Like approach 3, this approach represents active ecosystem management typically required when other goals such as water supply or energy production are less flexible. Conversely, this approach is based on the premise that other ecosystem elements can compensate for the undesirable effects of modified streamflow.

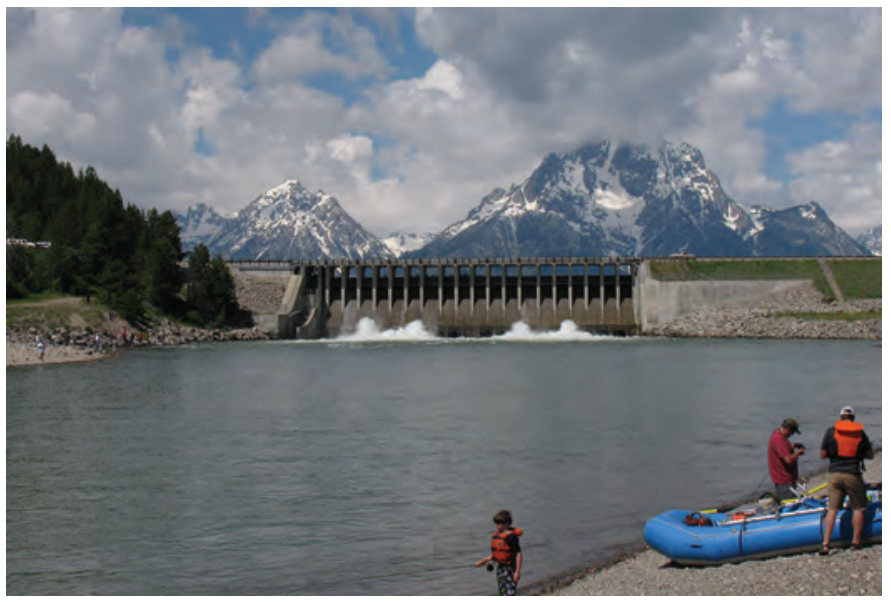

Recreational use on the Snake River, Wyoming, downstream from Jackson Lake Dam. Photograph by D. Carlisle, U.S. Geological Survey. 


\section{Where Does Streamflow Modification Influence Biological Diversity?}

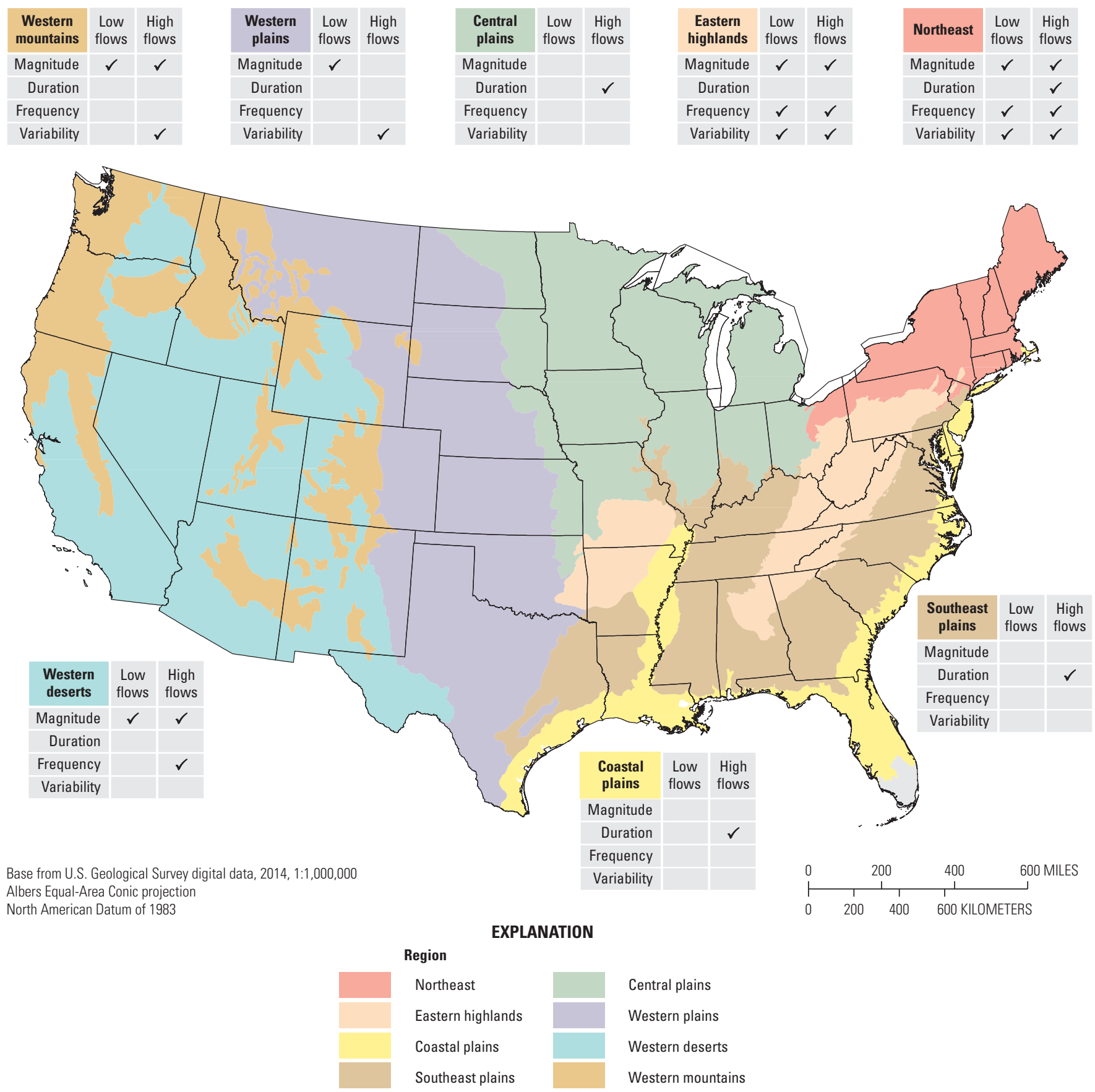

Figure A3. In every region assessed by the U.S. Geological Survey, reduced diversity of invertebrate or fish communities was associated with modification of natural attributes of streamflow (indicated by checkmarks). 


\section{How Big Data Can Help Improve the Nation's Waterways-An Example from California}

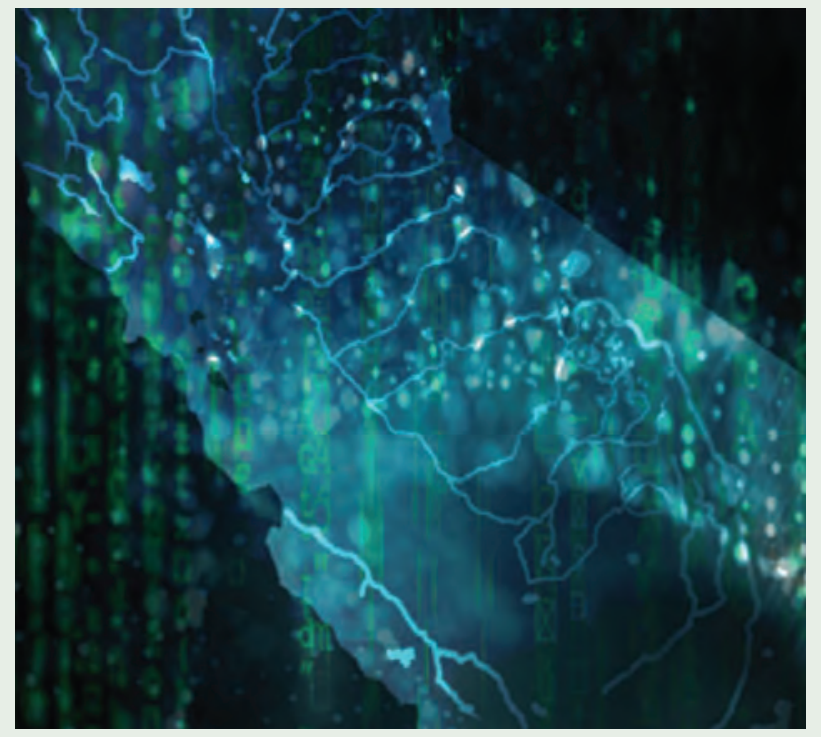

What happens when tech partners with scientists, conservationists, and environmentalists? We can better understand and analyze the Nation's rivers, streams, and waterways. An example from California offers a vision of how such synergy can take shape. Started in 2017, Data4Rivers is a project partnership between AT\&T, The Nature Conservancy, and U.S. Geological Survey (USGS). The project partners recently finished the Data4Rivers Accelerator Phase. Data4Rivers uses Big Data analytics tools to fill a critical gap in scientific data about California's waterways, allowing the environmental community to more accurately measure and track water quality and water conservation strategies.

\section{How Data4Rivers Works}

"Data4Rivers delivers critical data that otherwise would not exist - near real-time predictions of unimpaired flow in ALL our rivers using USGS models," says Jeanette Howard, Ph.D. and director of science at The Nature Conservancy. "This project will ultimately help us understand how to better manage water flows for the environment."

According to Howard, the challenge is largely institutional in that the data are often housed in different places at different agencies and in different, often outdated, code languages.

"This is a problem governments and nonprofits encounter over and over again," said Howard. "The data and code may exist but digital archeology is often needed to bring the past work into the present."
AT\&T data scientists volunteered their time to help complete the Accelerator Phase of the Data4Rivers project to provide the push needed to overcome the institutional barriers. To update USGS models to predict near real-time natural water flows, AT\&T's team worked closely with the USGS researchers to better understand the various models and datasets needed to update the natural flow data and translated five layers of existing code into more modern languages.

"The environmental community had a problem it needed solving, so we brought in our team with expertise in Big Data insights," said Neeru Sharma, AT\&T Business Management, Insights Development. "We use our resources and technical capabilities to make positive contributions to society; that is why we got involved with Data4Rivers."

\section{The Big Data Difference}

The first step to understanding impacts to rivers and streams is knowing how much water would be in a river under "natural" conditions, with no dams, diversions, land use change, or other human-caused changes. Once the natural (or "expected") conditions are known, it is possible to measure available water levels to determine the difference between observed and expected.

Once complete, the software code developed through the Data4Rivers project will automatically calculate how much water would be in a given river or stream on average for any month without dams or diversions (unimpaired flows). This information can be used to investigate possible causes for changes in wildlife populations or other ecological responses. Having this modeling data will be useful for many types of analyses, such as the following:

1. Water quality.-As water flow goes down, so does water quality in many cases. It is useful to be able to compare actual flow to estimated flow to indicate places where water quality might be declining.

2. Tracking progress on conservation strategies.-As California implements water conservation strategies and adds more water to the environment, there is a need for a real-time tracking method to see if these strategies are working.

3. Tracking unsanctioned diversions.-It is imperative to use data to inform whether more water is being diverted from California's waterways than it should, potentially leading to more water for the environment.

The data generated from the Data4Rivers project will be made available to the public from The Nature Conservancy, https://rivers.codefornature.org/, so scientists, researchers, and academic institutions can utilize the findings with the aim of improving California's waterways. 


\section{Chapter B. National Assessment of Streamflow Modification}

Streams and rivers are dynamic features of the landscape, constantly moving and ever changing. Their flowing waters support rich and diverse ecosystems, delight users with recreational opportunities, and provide precious water for communities, agriculture, and industry. The ability of streams and rivers to provide these important services depends upon the many characteristics of flow, such as the magnitude, the duration, and the frequency. A healthy ecosystem is best maintained when flows fluctuate in a natural manner (Palmer and others, 2009).

Until now, these critical characteristics of streamflow had not been assessed at a national scale. The USGS National Water-Quality Assessment (NAWQA) Project set out to evaluate the degree to which streamflow differs from natural patterns at 3,355 streamgaging sites across regions and across the contiguous United States (see "How Was Streamflow Characterized and Assessed?" box) and to assess how streamflow is affected by different types of land and water management (Eng and others, 2019).

Land- and water-management practices have modified natural streamflows across the Nation. Low flows are more frequent, are of shorter duration, and vary less from one year to the next than they would naturally. High flows have been reduced, are less frequent, are of shorter duration, and vary less from one year to the next than they would naturally. In addition, daily flow fluctuations are higher than natural across the Nation.

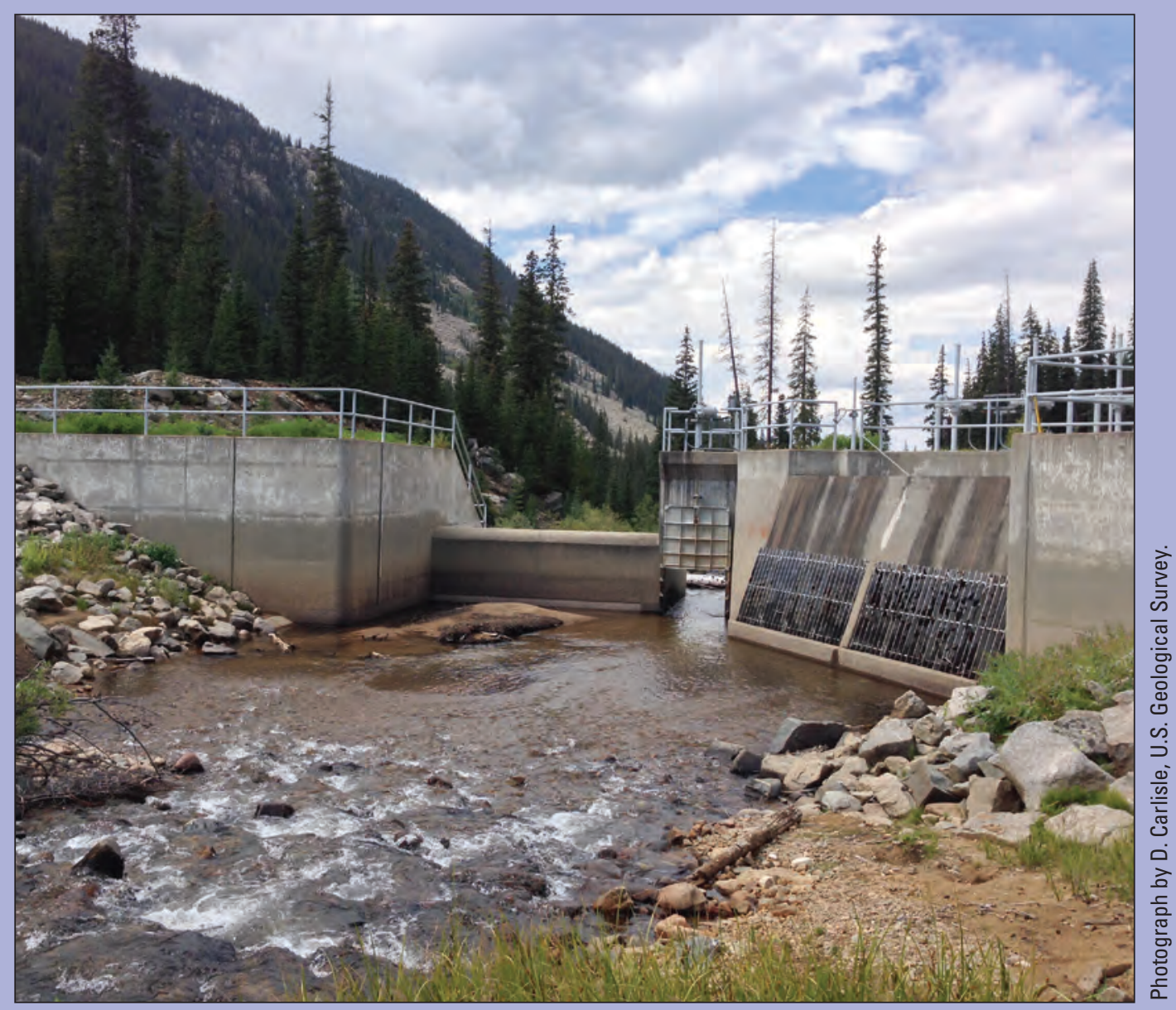

Land- and water-management practices have modified natural streamflows across the Nation. The diversion in this photograph removes water from the stream and transfers it to a stream in a different river basin. 


\section{How Was Streamflow Characterized and Assessed?}

\section{Streamflow Characteristics}

The natural patterns of streamflow include many different dimensions and cannot be summarized into a single measure. Six measures of streamflow are discussed in this report. All are derived from measurements of daily mean streamflow from U.S. Geological Survey streamgages.

Flow magnitude indicates how much water is present in a stream at a given time (as volume per unit time). The duration indicates how long (in days) a specific flow magnitude persists, whereas the frequency indicates how often a specific flow magnitude occurs (in counts per unit time).

In addition, annual variability indicates how flow magnitude fluctuates from year to year, whereas daily flow fluctuation indicates how streamflows vary from day to day.

Finally, the timing of flow magnitude also is an important measure of the natural patterns of streamflow. Although timing itself was not assessed in this report, examples are provided to demonstrate the importance of this dimension of streamflow.

\section{Assessing Streamflow Modification}

For each streamflow indicator described above, machine-learning models were used to estimate the natural baseline at each streamgage. The natural baseline is the best approximation of streamflow conditions in the absence of human influences. Of particular importance, climatic variability was accounted for when estimating natural baselines, which ensures that differences between estimated baselines and actual observed conditions are not affected by climate. At each streamgage, data from daily streamflow measurements were used to compute each streamflow indicator for the period 1980-2014. Streamflow modification is defined as the difference between the measured streamflow indicator and the expected natural baseline at the same streamgage (Eng and others, 2019).

\section{Streamflow Magnitude}

Magnitude describes the flow rate (in volume per unit time) of water in a stream and is used to describe low- and high-flow conditions (see the "What Is Flow Magnitude?" box). All streams have relatively low flow sometimes, typically during periods with little rainfall. Similarly, all streams have relatively high flow at times, typically after rainfall or snowmelt. The health of stream ecosystems and the availability of water for human uses-recreation, irrigation, and drinking — depend on the volume of flow in a stream.

Low-flow magnitude was either lower or higher than natural at 84 percent of assessed streams (fig. B1). Lowflow magnitude was commonly lower than natural in the western deserts, western mountains, western plains, and coastal plains; higher than natural low flows were most common in all other regions. These regional differences in the modification of low-flow magnitudes have been attributed to regional differences in land and water management (Carlisle and others, 2011); for example, flood-control reservoirs, common in areas with wetter climates, such as the northeast, release stored water into streams during periods of naturally low flows. As a result, low flows in these regions are higher than they would be naturally.

High-flow magnitude, unlike low-flow magnitude, was lower than natural in most streams assessed in every region (fig. B2). Nationally, high-flow magnitude was lower than natural at more than two-thirds of assessed streams. The prevalence of lower than natural high flows has been attributed to the pervasive effect of flood management efforts (Carlisle and others, 2011).

In most assessed streams, the

magnitude of low flows was higher

than natural and the magnitude of high flows was lower than natural.

\section{Streamflow Duration}

Duration refers to the length of time that streamflow magnitude is above or below a specific threshold - typically the threshold that defines either low or high flows (see the "What Is Flow Duration?" box). The duration of high and low flows has profound effects on stream ecosystems; for example, the high flows above a specific magnitude and for a sufficient duration are critical for maintaining the physical structure of the stream channel and habitats for many species.

The low-flow duration was shorter than natural at nearly two-thirds of assessed sites across the Nation (fig. B3). There were few regional differences - most of the sites assessed had a low-flow duration that was shorter than 


\section{What Is Flow Magnitude?}

Magnitude indicates the flow rate, measured as volume per unit time, such as gallons per minute. High and low flows were defined as the highest 1 percent of all daily streamflow values; that is, the daily value greater than 99 percent of all other daily values. Low-flow magnitude was defined as the lowest 1 percent of all daily streamflow values; that is, the daily value less than 99 percent of all other daily values (Eng and others, 2019). In the example below, 20 years of daily flow values are shown for Holiday Creek, Virginia. The horizontal lines show the values for high-flow magnitude (highest 1 percent) and low-flow magnitude (lowest 1 percent).

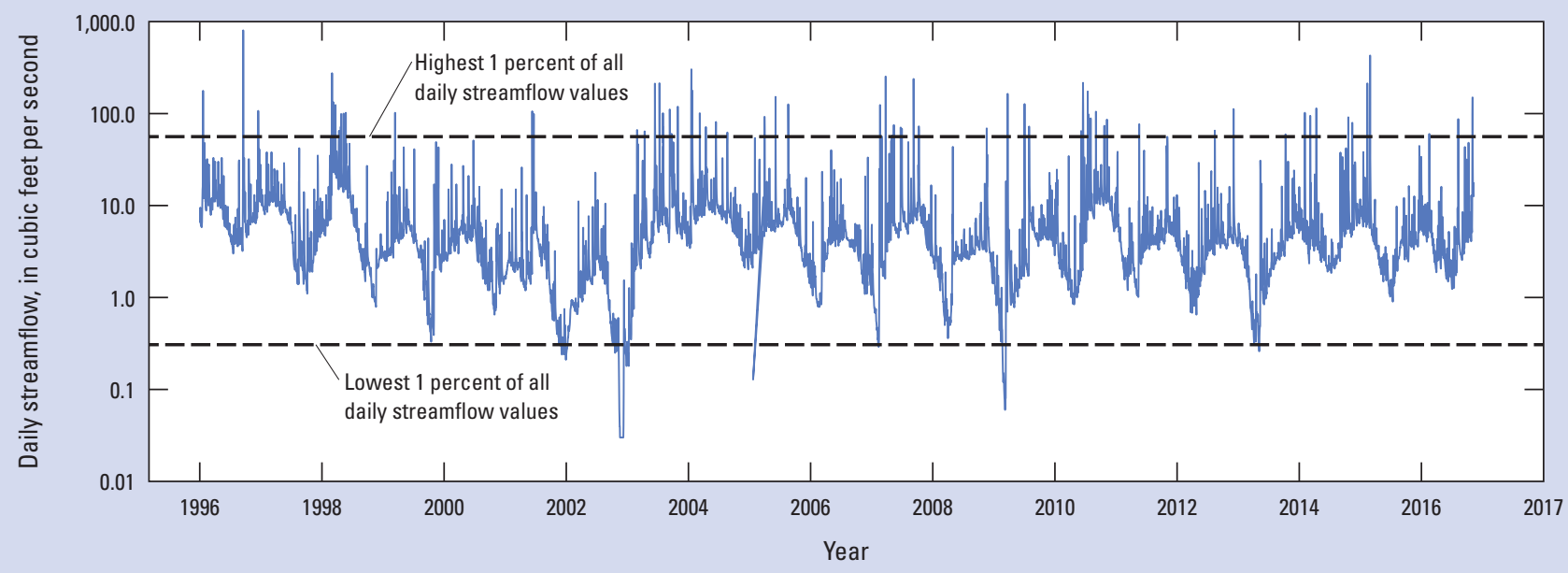

natural. The lack of regional variability indicates that land and water management affect low-flow duration in similar ways regardless of the wide variety of climates across the Nation.

High-flow duration was either shorter or longer than natural at 85 percent of assessed sites across the Nation (fig. B4). In contrast to low-flow duration, modifications to high-flow duration varied among regions. Most sites in the central and eastern United States - the central plains, southeast plains, northeast, and eastern highlands - had longer than natural high-flow durations. In contrast, most sites in the arid west and coastal plains had shorter than natural high-flow durations. This regional pattern is similar to that seen for streamflow magnitude and suggests that water-management practices in the arid west and coastal plains reduce the magnitude and duration of high flows.

\section{Duration of low flows was}

shorter than natural at most

assessed streams nationally, but

there were regional differences

to the modification of high flow.

\section{What Is Flow Duration?}

Duration is the length of time, usually days during a year, that streamflow is above or below a high-flow or low-flow threshold (as described in the "What Is Flow Magnitude?" box). Each stream has its own thresholds that are determined from long-term streamflow data. In the example below, the annual high-flow duration for 2016 for the stream shown was 9 days (total length of horizontal green bars), and the low-flow duration was 107 days (red bars). For each stream site, the 20-year average of yearly high- and low-flow duration was assessed (Eng and others, 2019).

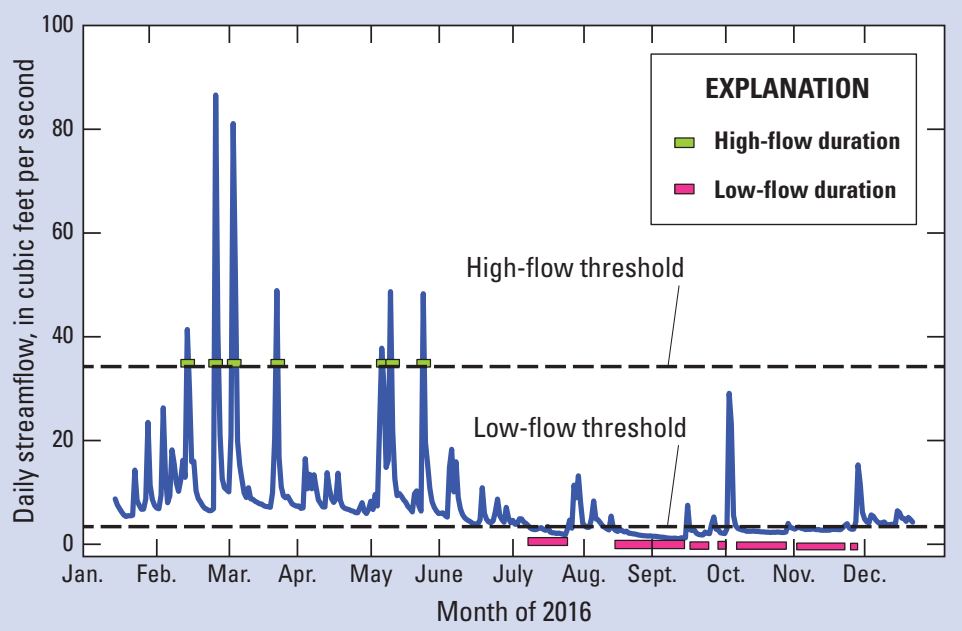




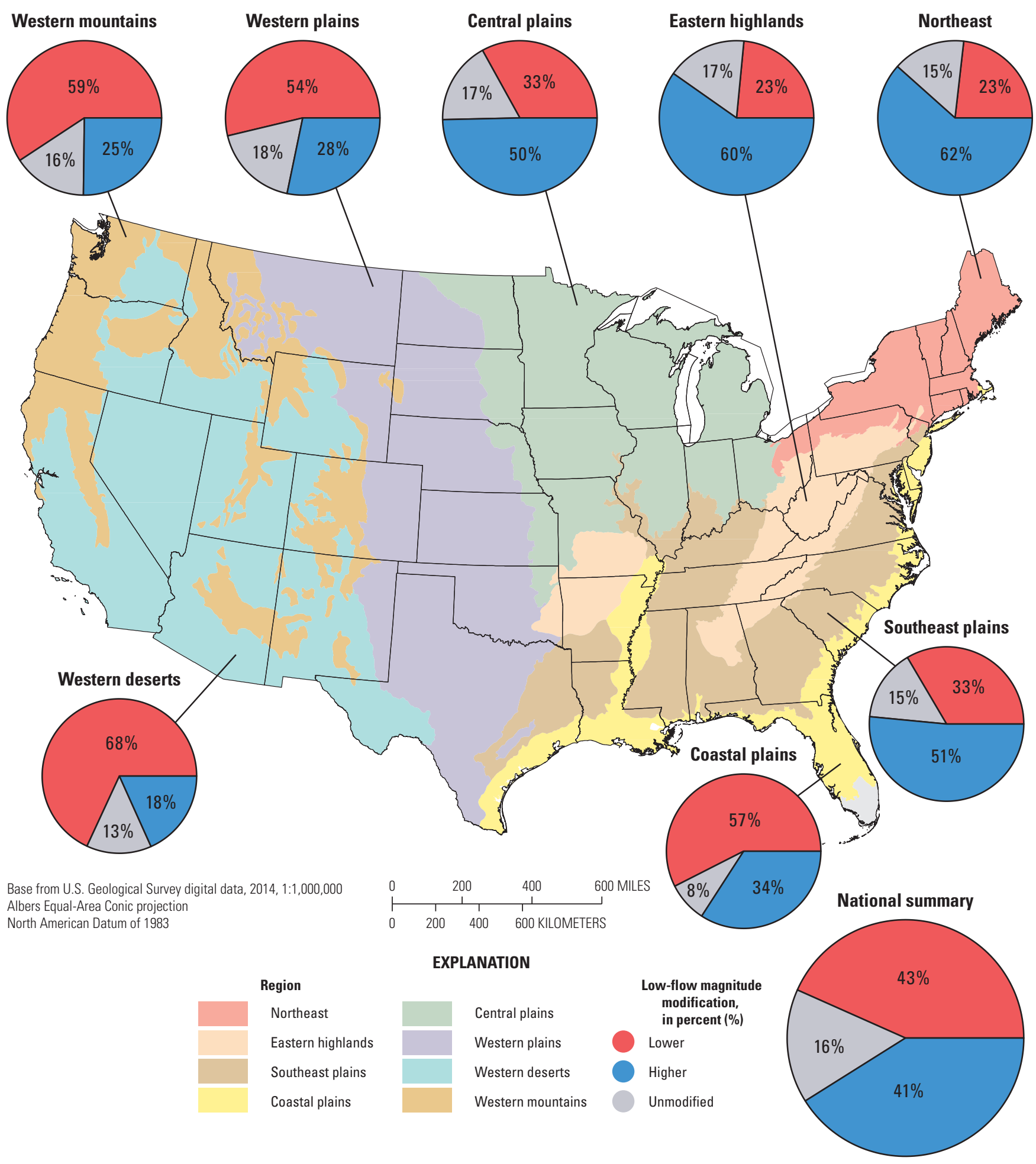

Figure B1. Regional summaries of the modification of low-flow magnitude, categorized as being higher, lower, or unmodified relative to natural conditions. Pie graphs show percentage of assessed U.S. Geological Survey streamgages in each region within each category of modification. 


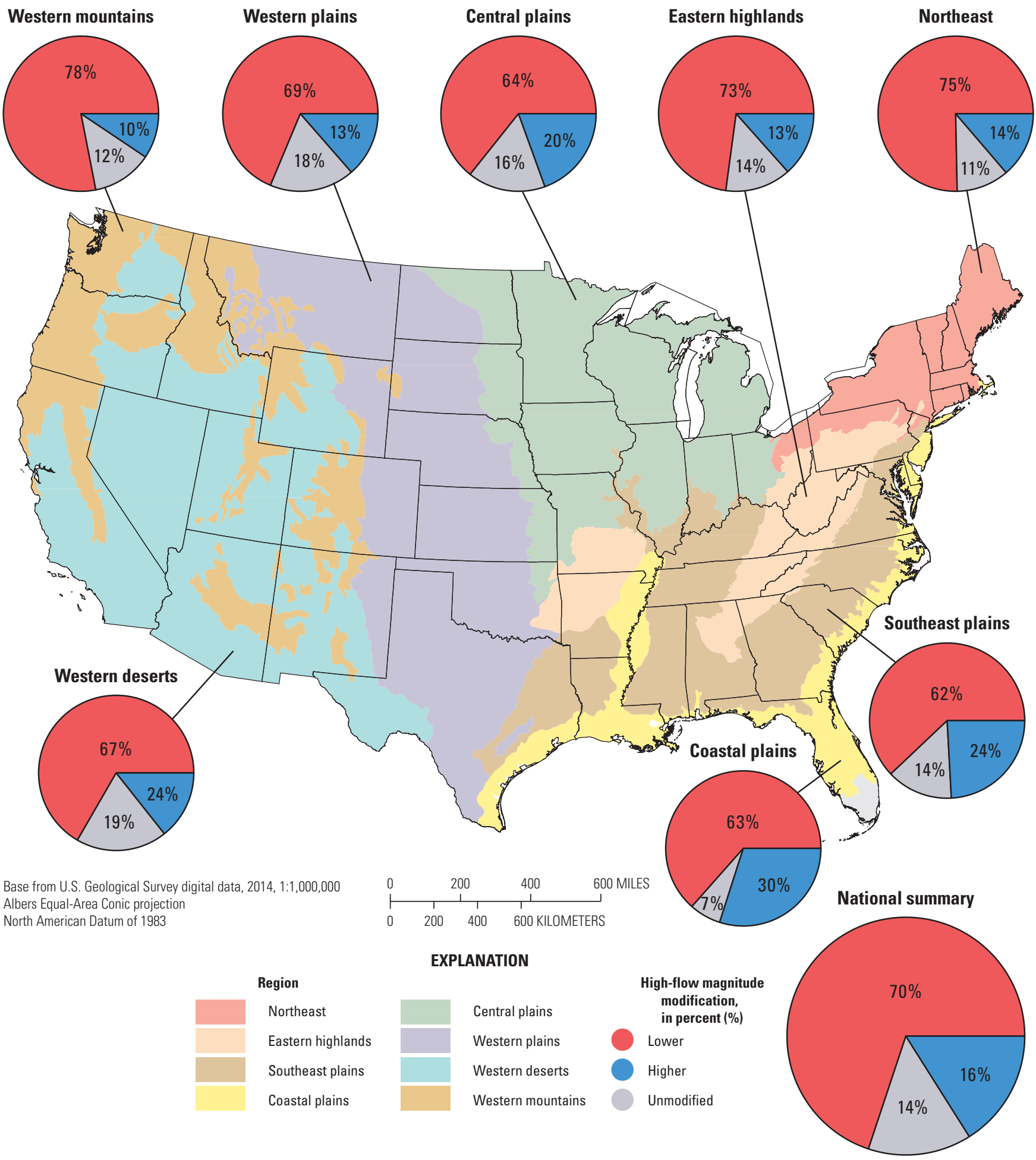

Figure B2. Regional summaries of the modification of high-flow magnitude, categorized as being higher, lower, or unmodified relative to natural conditions. Pie graphs show percentage of assessed U.S. Geological Survey streamgages in each region within each category of modification. 


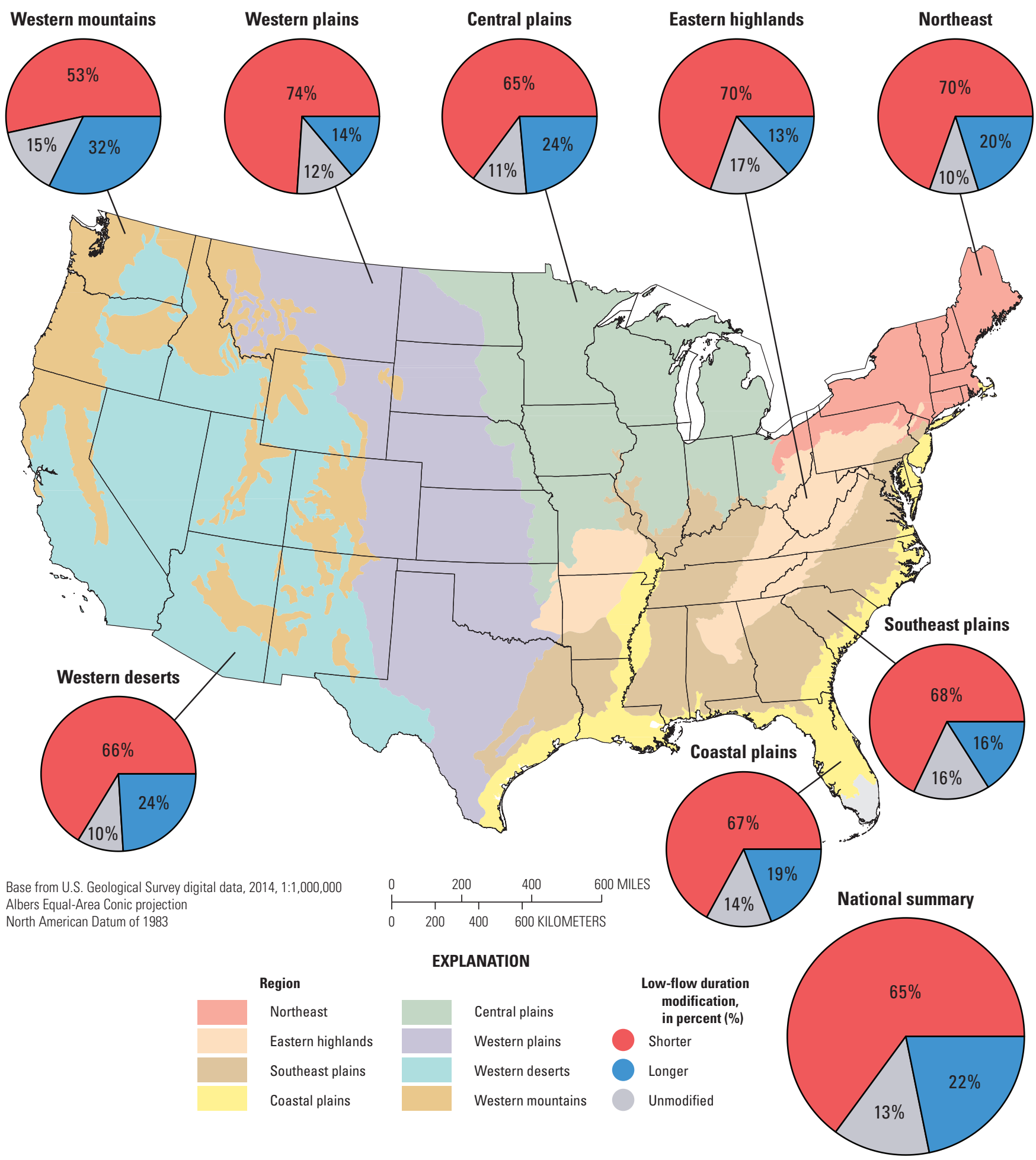

Figure B3. Regional summaries of the modification of low-flow duration, categorized as being longer, shorter, or unmodified relative to natural conditions. Pie graphs show percentage of assessed U.S. Geological Survey streamgages in each region within each category of modification. 


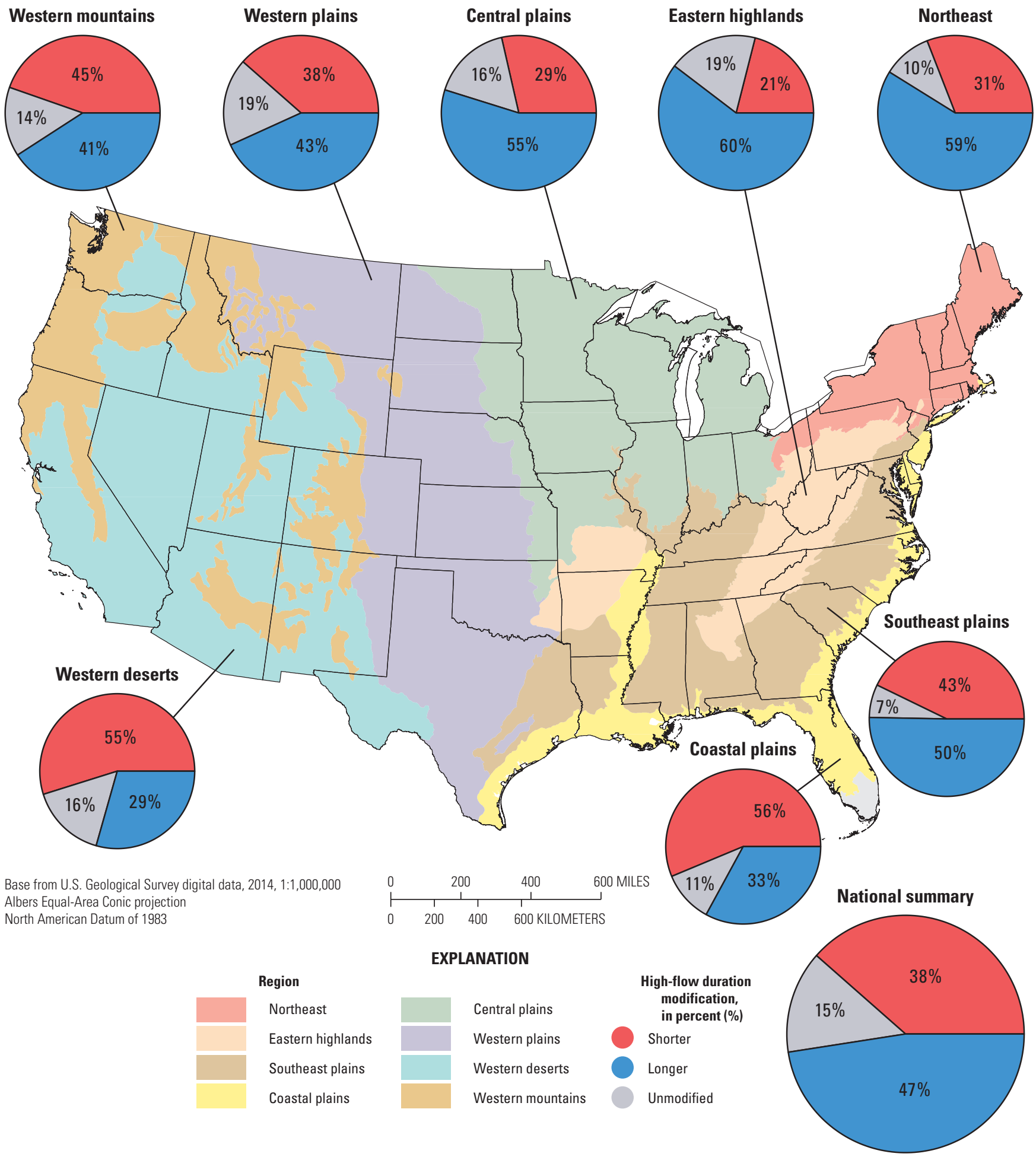

Figure B4. Regional summaries of the modification of high-flow duration, categorized as being longer, shorter, or unmodified relative to natural conditions. Pie graphs show percentage of assessed U.S. Geological Survey streamgages in each region within each category of modification. 


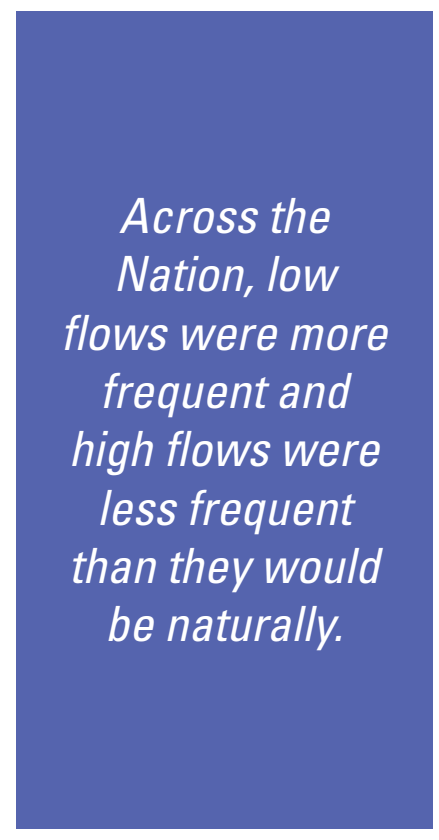

\section{Streamflow Frequency}

Frequency refers to the number of times (typically per year) that streamflow magnitude crosses the thresholds that define low and high flow for that stream (see the "What Is Flow Frequency?" box). Frequency, like other aspects of streamflow, must remain within certain bounds to maintain healthy stream ecosystems; for example, high flows that are too frequent can harm species that rely on periods of low flow. On the other hand, if high flows are not frequent enough, their ecological benefits are rarely realized.

In general, low flows across the Nation were more frequent than natural. Nationally, lowflow frequency has increased, relative to natural conditions, at 60 percent of the stream sites assessed (fig. B5). Further, most assessed sites in all regions also had increased frequency of low flows, which suggests that most types of land and water management in all types of climates tend to increase the frequency of low flows.

The frequency of high flows, in contrast, was generally lower than it would be naturally across the Nation. High-flow frequency across the Nation has decreased relative to natural conditions at about one-half of the sites assessed (52 percent) and has increased at about onethird of the sites ( 32 percent; fig. B6). In most regions, streams with less frequent high flows were more common than streams with more frequent or unaltered high flows; however, in two regions - western deserts and coastal plains - streams with more frequent high flows were as common as those with less frequent high flows.

\section{What Is Flow} Frequency?

Frequency measures how many times each year streamflow crosses either the high- or low-flow threshold (as described in the "What Is Flow Magnitude?" box). Thresholds are unique to each stream and estimated from longterm streamflow data. In the example below, high-flow frequency for 2016 was seven, and low-flow frequency was also seven. The 20 -year average of high- and lowflow frequencies at each streamgage were assessed (Eng and others, 2019).

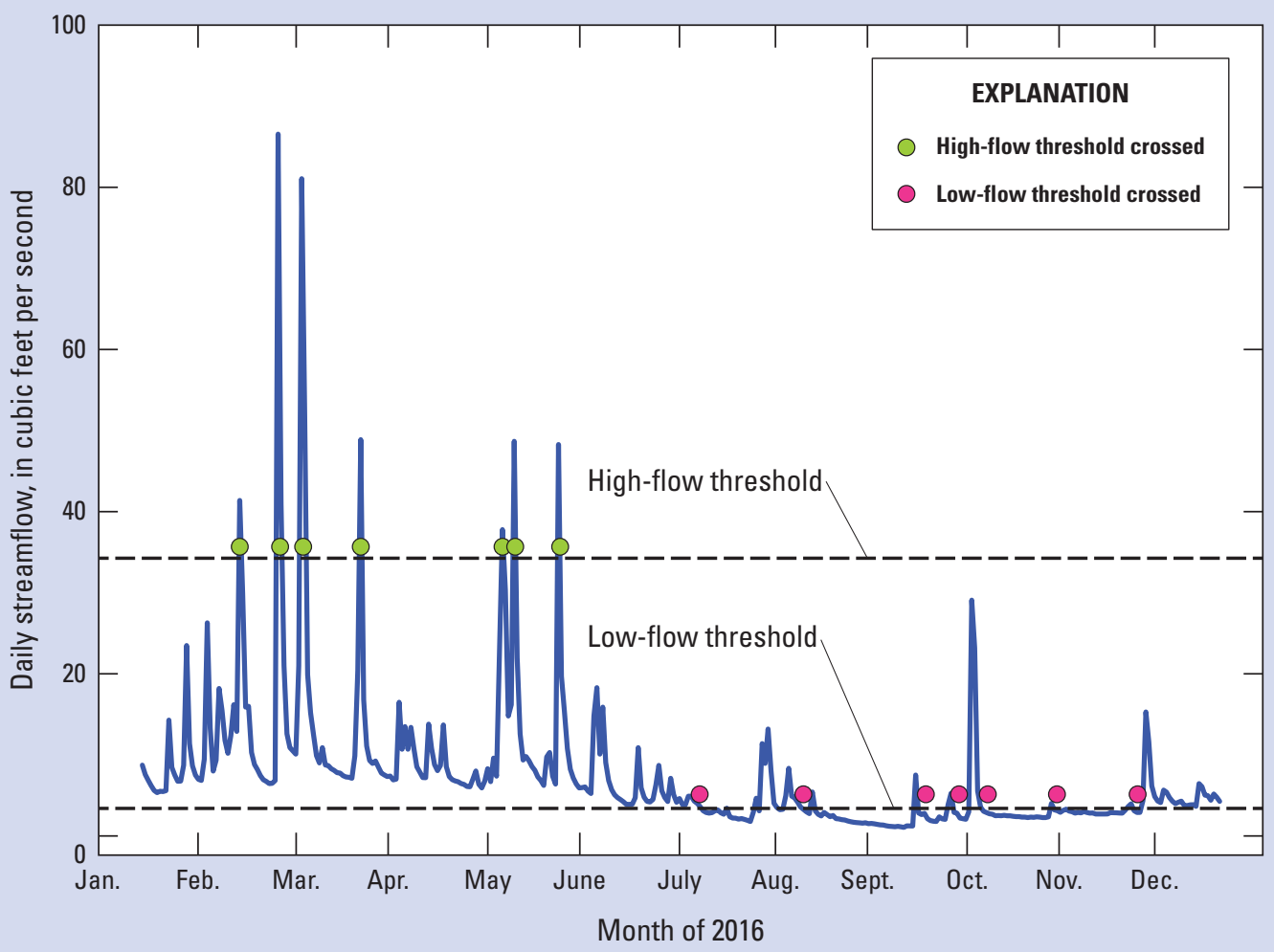




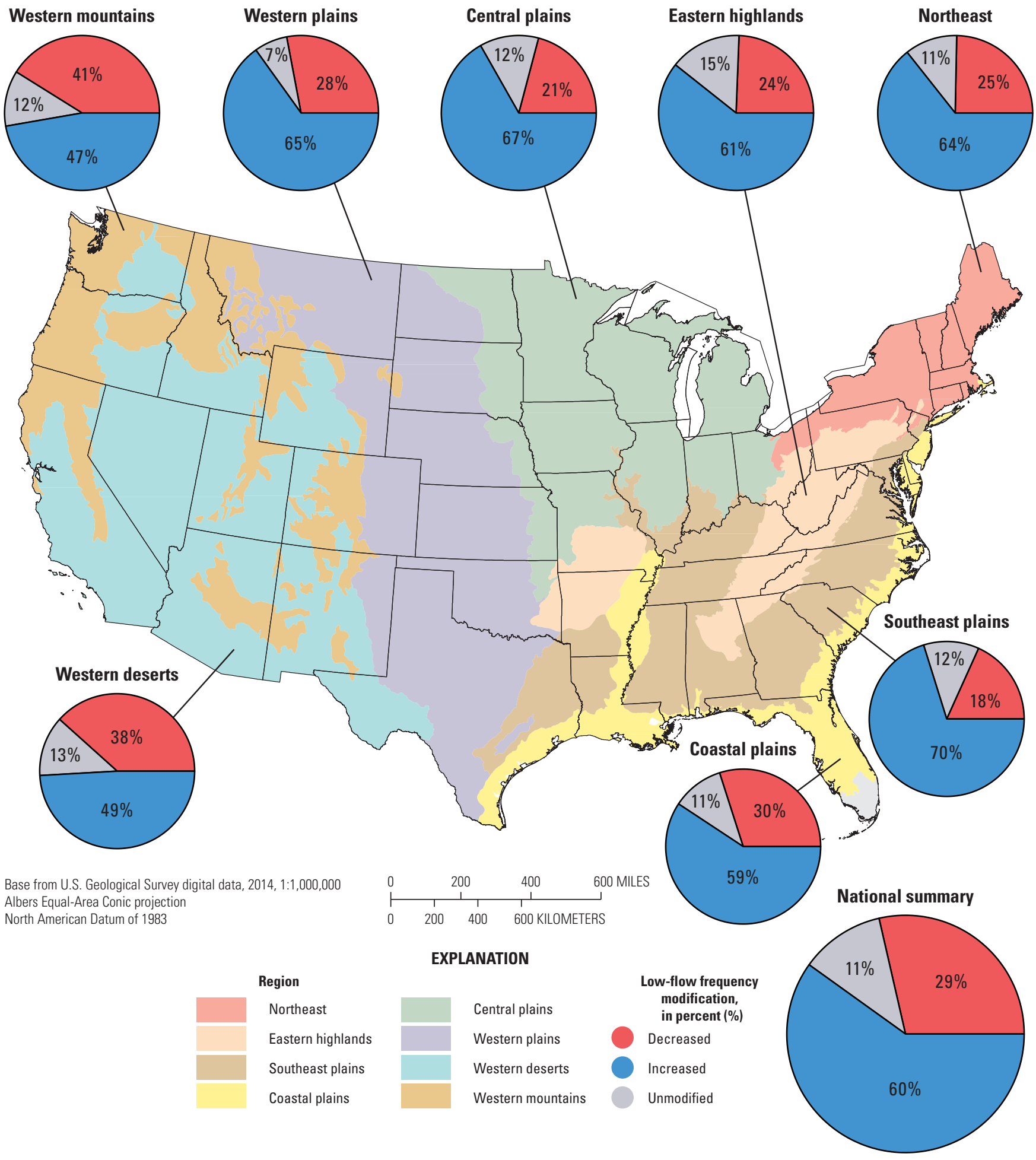

Figure B5. Regional summaries of the modification of low-flow frequency, categorized as being increased, decreased, or unmodified relative to natural conditions. Pie graphs show percentage of assessed U.S. Geological Survey streamgages in each region within each category of modification. 


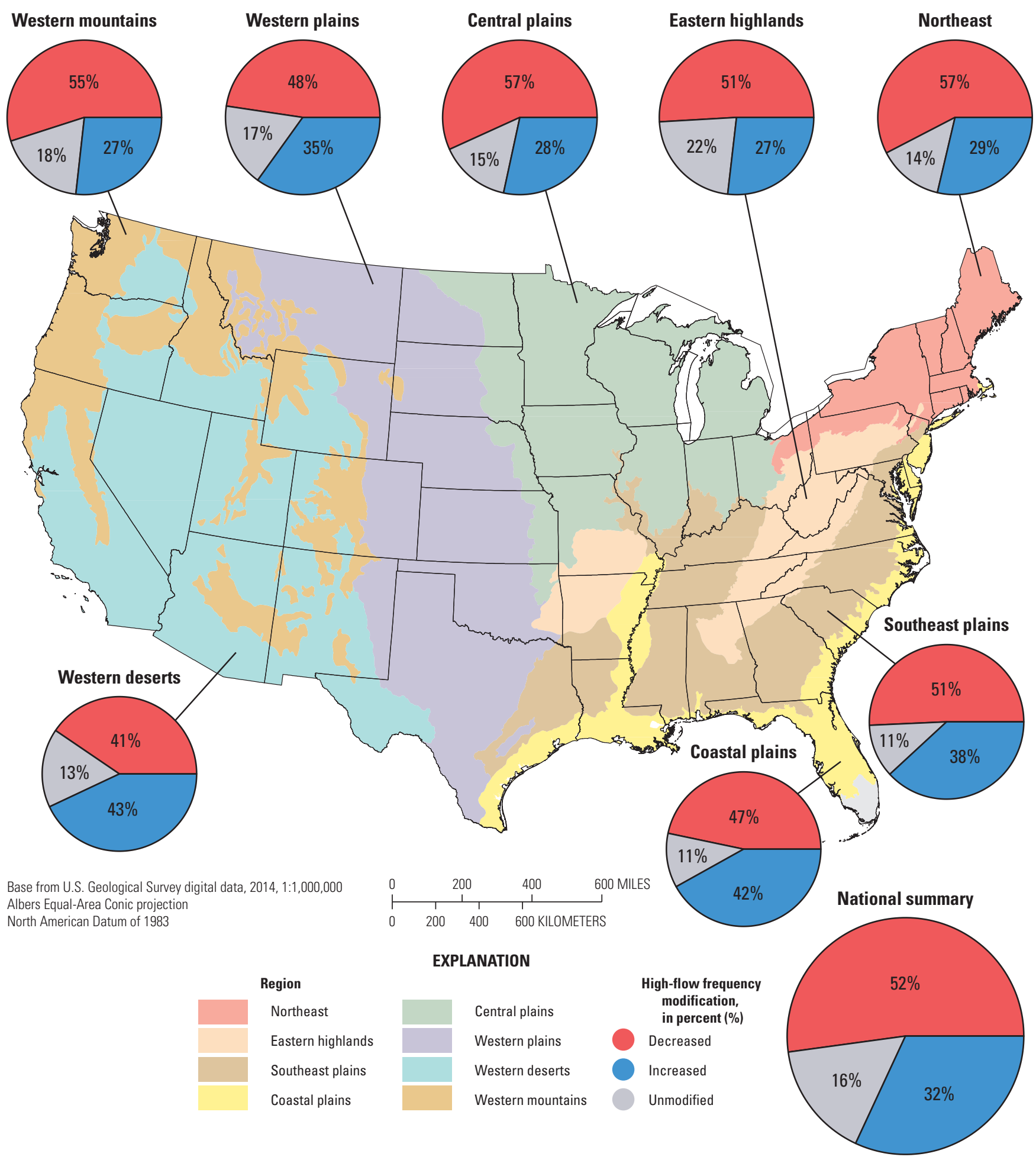

Figure B6. Regional summaries of the modification of high-flow frequency, categorized as being increased, decreased, or unmodified relative to natural conditions. Pie graphs show percentage of assessed U.S. Geological Survey streamgages in each region within each category of modification. 


\section{Annual Variability of Streamflow}

The magnitude, duration, and frequency of high and low flows for a stream vary from one year to the next, depending on precipitation each year (see the "What Is Annual Flow Variability?" box). Too much or too little annual variability can affect water availability for our many needs and can have harmful ecological consequences; for example, extreme year-to-year variability in streams of the southern plains is helpful for maintaining high diversity of native fish species. It is believed that annual variability in streamflows creates a variety of favorable conditions from year to year for the successful reproduction of many species.

The annual variability of low and high flows in streams across the Nation has decreased relative to natural conditions. Low-flow variability has decreased at 65 percent of the sites assessed, and high-flow variability has decreased at 59 percent of sites assessed (figs. B7 and $\mathrm{B} 8$, respectively). Streams with decreased high- or low-flow variability were predominant in all regions, indicating that most types of land- and water-management practices have a tendency to make streamflows more similar from year to year, regardless of the climate.

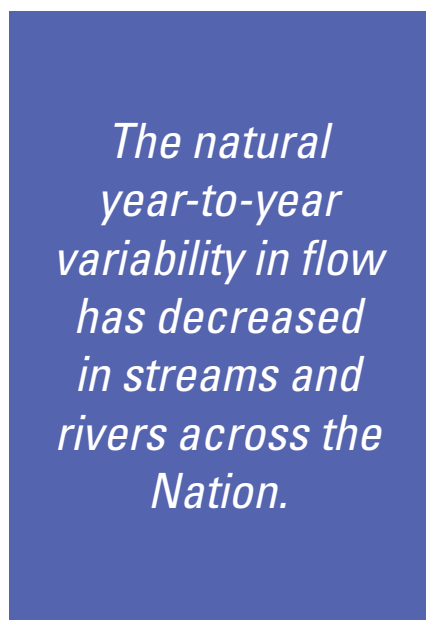

\section{What Is Annual Flow Variability?}

In this report, variability is a measure of year-to-year differences in high- and low-flow magnitudes, as measured over 20 or more years (Eng and others, 2019). This annual variability is an indicator of how predictable streamflows are from one year to the next. In this example for Vallecito Creek, Colorado, low flows ranged from 3 cubic feet per second $\left(\mathrm{ft}^{3} / \mathrm{s}\right)$ in 1975 to $29 \mathrm{ft}^{3} / \mathrm{s}$ in 1985 but are typically between 10 and $20 \mathrm{ft}^{3} / \mathrm{s}$. High flows ranged from $400 \mathrm{ft}^{3} / \mathrm{s}$ in 1976 to $1,800 \mathrm{ft}^{3} / \mathrm{s}$ in 2006 but are typically between 600 and $1,200 \mathrm{ft}^{3} / \mathrm{s}$.

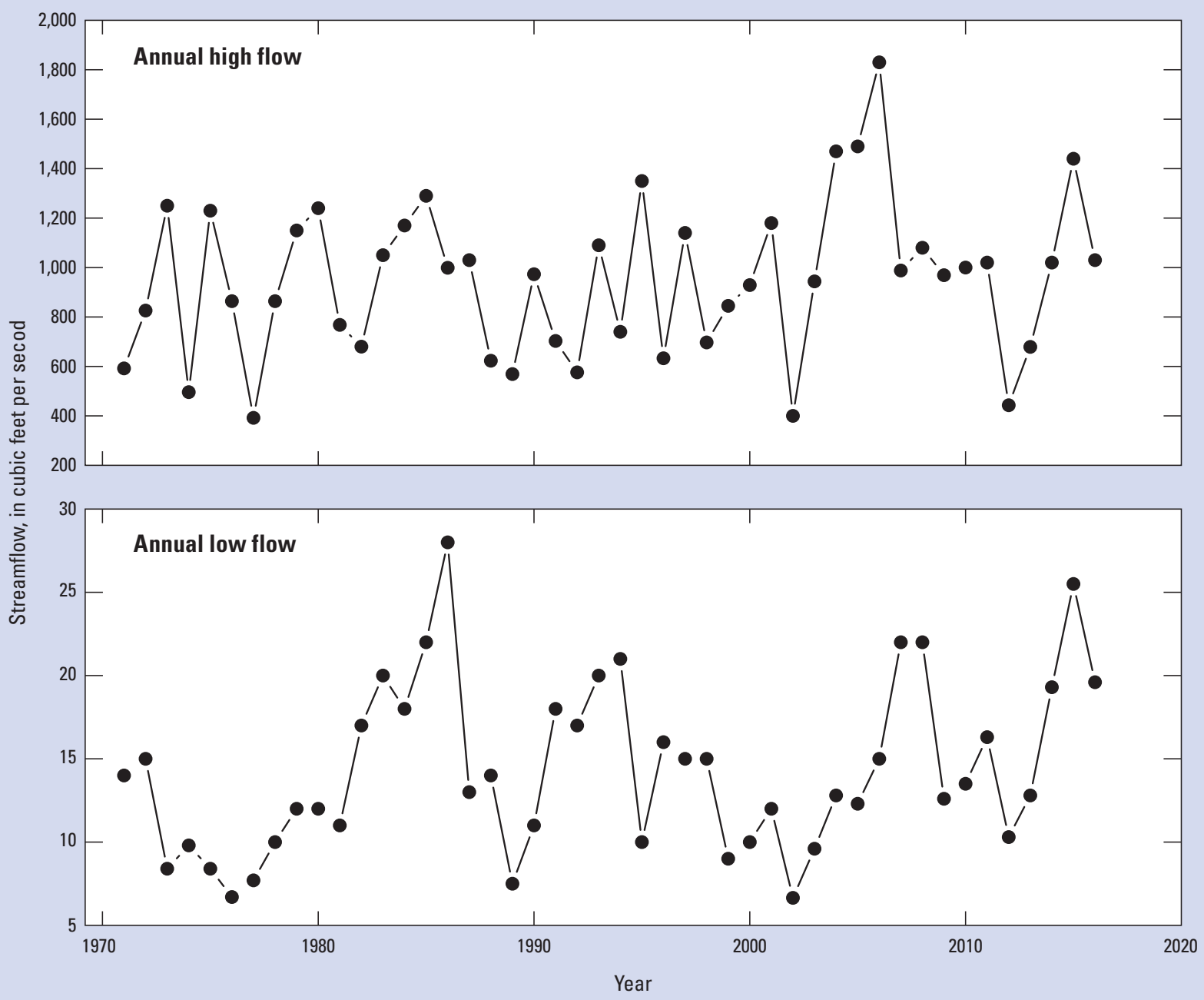




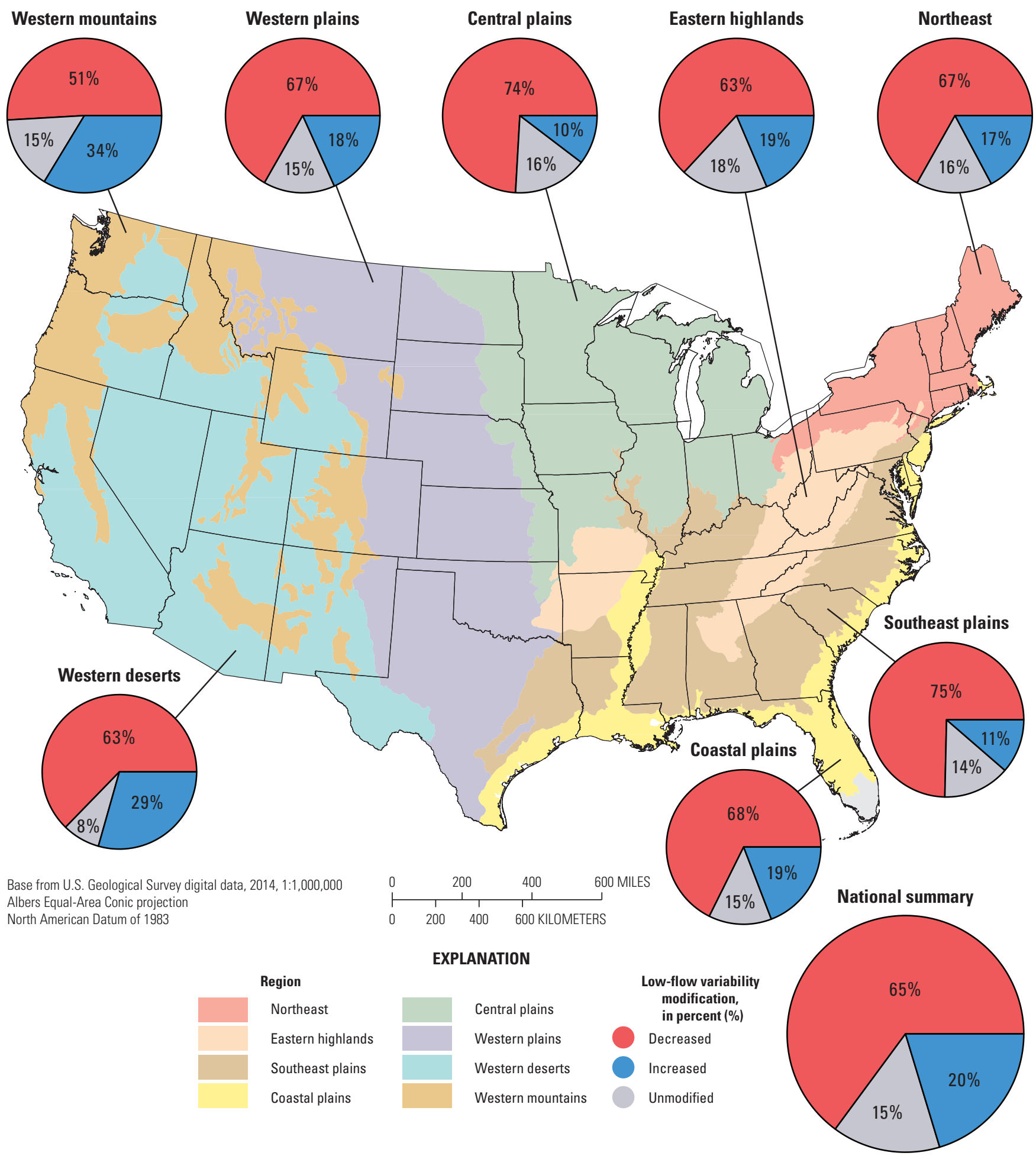

Figure B7. Regional summaries of the modification of low-flow variability, categorized as being increased, decreased, or unmodified relative to natural conditions. Pie graphs show percentage of assessed U.S. Geological Survey streamgages in each region within each category of modification. 


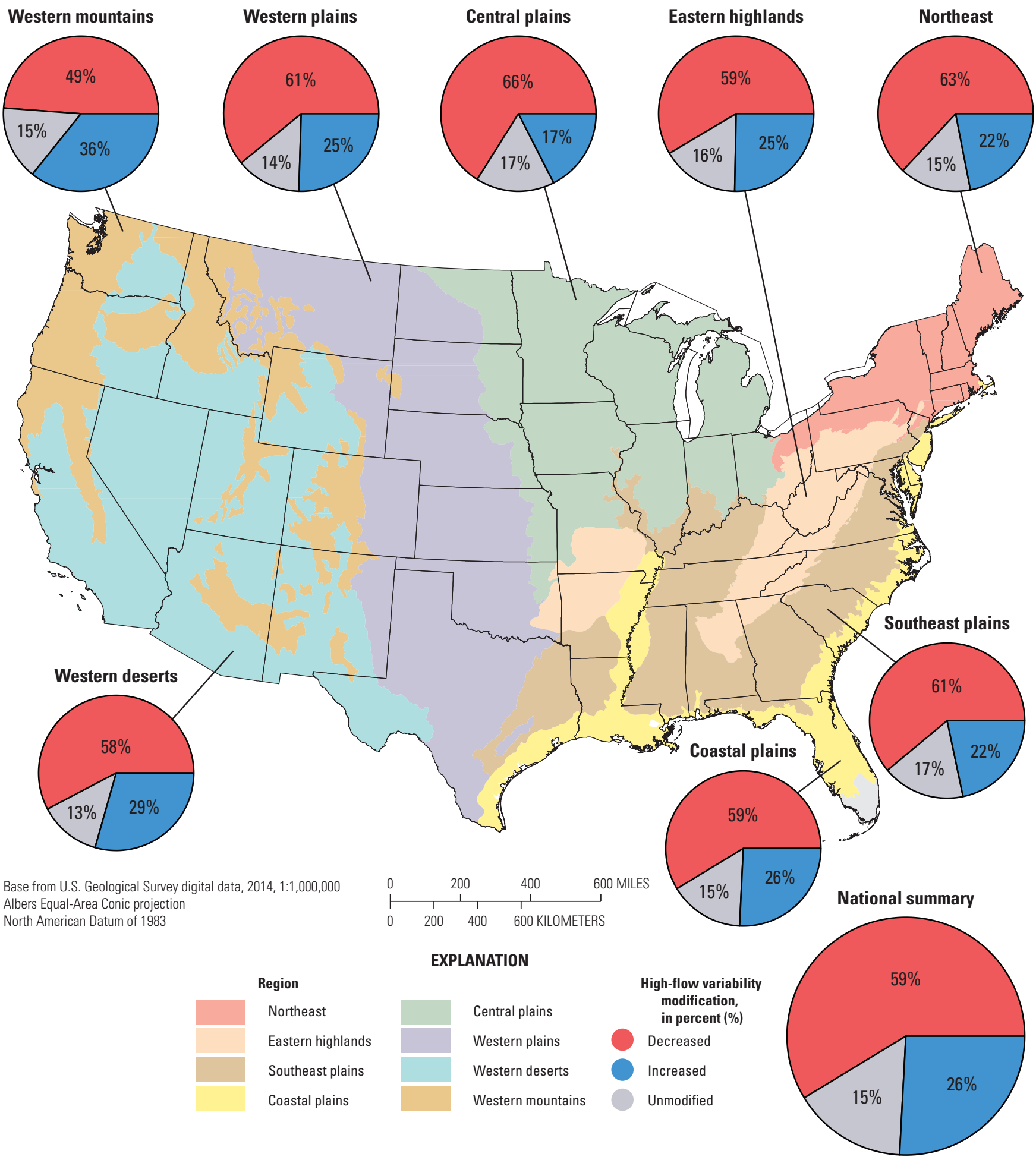

Figure B8. Regional summaries of the modification of high-flow variability, categorized as being increased, decreased, or unmodified relative to natural conditions. Pie graphs show percentage of assessed U.S. Geological Survey streamgages in each region within each category of modification. 


\section{Across the}

Nation, most

assessed

streams

had greater

than natural

fluctuations in

daily flow.

\section{Daily Flow Fluctuation}

Flows in most streams fluctuate seasonally with the natural cycles of precipitation and dryness. Under natural conditions, day-to-day fluctuations are minimal in the absence of storms (see the "What Is Flow Fluctuation?" box). Higher than natural daily flow fluctuations are harmful to stream health because they create a harsh environment of changing wet and dry conditions along the edges of the stream.

Across the Nation, most assessed streams in all regions and types of land- and water-management settings had higher than natural daily flow fluctuation (fig. B9). This finding indicates that most land- and water-management practices cause an increase in streamflow fluctuations, albeit for different reasons (see next chapter).

\section{What Is Flow Fluctuation?}

Natural processes like rainfall and snowmelt cause streamflow to fluctuate from one day to the next. One way to measure daily flow fluctuation is to count the number of days over a specified time period that flow is higher than it was the day before (Eng and others, 2019). The graph below shows an example of a stream with unnaturally high fluctuations. The blue line shows daily flow in the San
Joaquin River in June of 2003. Each highlighted sequence shows a series of days in which flow on one day was higher than the previous day, for a total of 11 days. This high amount of flow fluctuation, which occurs on a regular basis, is caused by water-management activities such irrigation diversions and return flows.

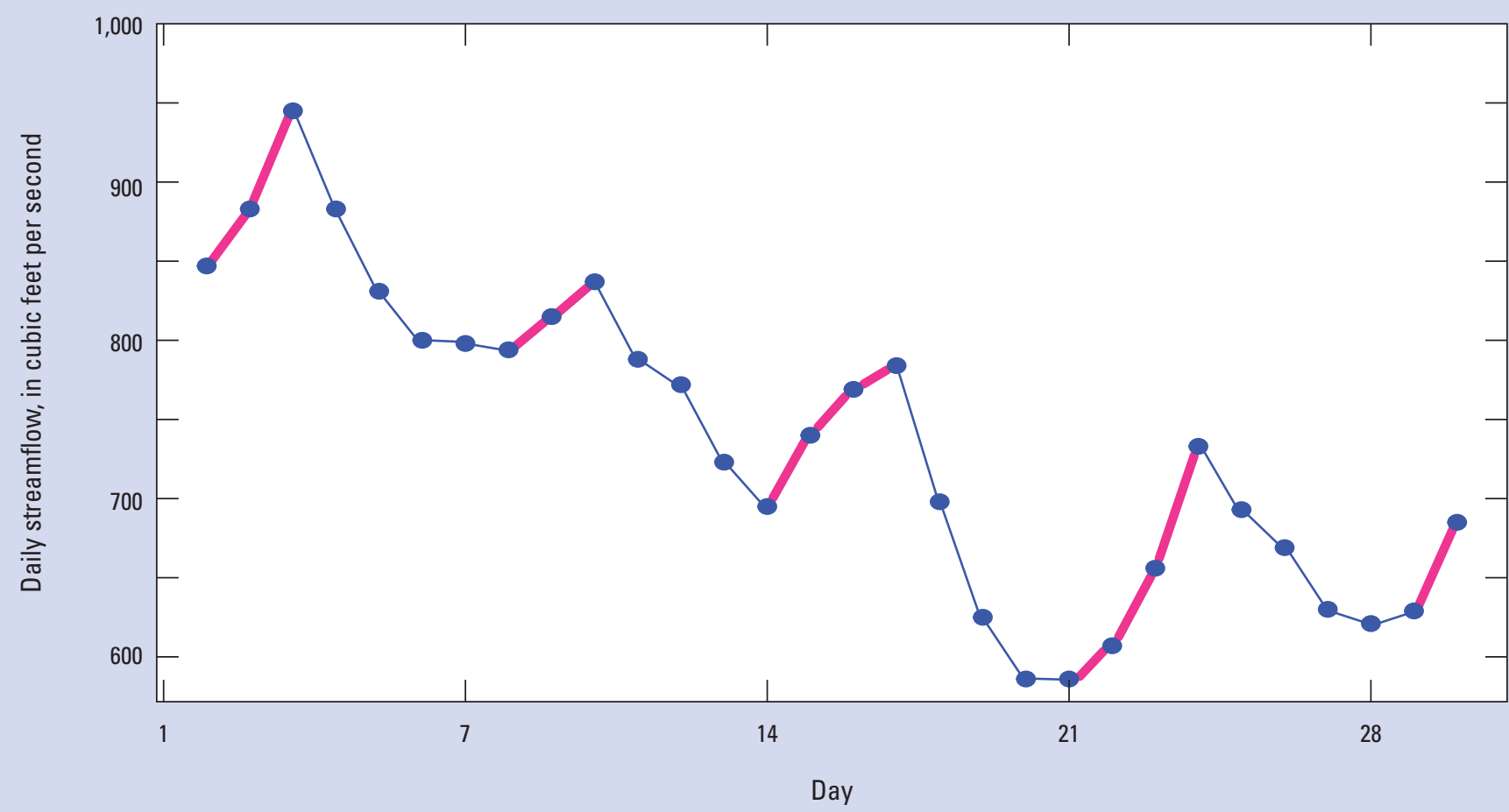




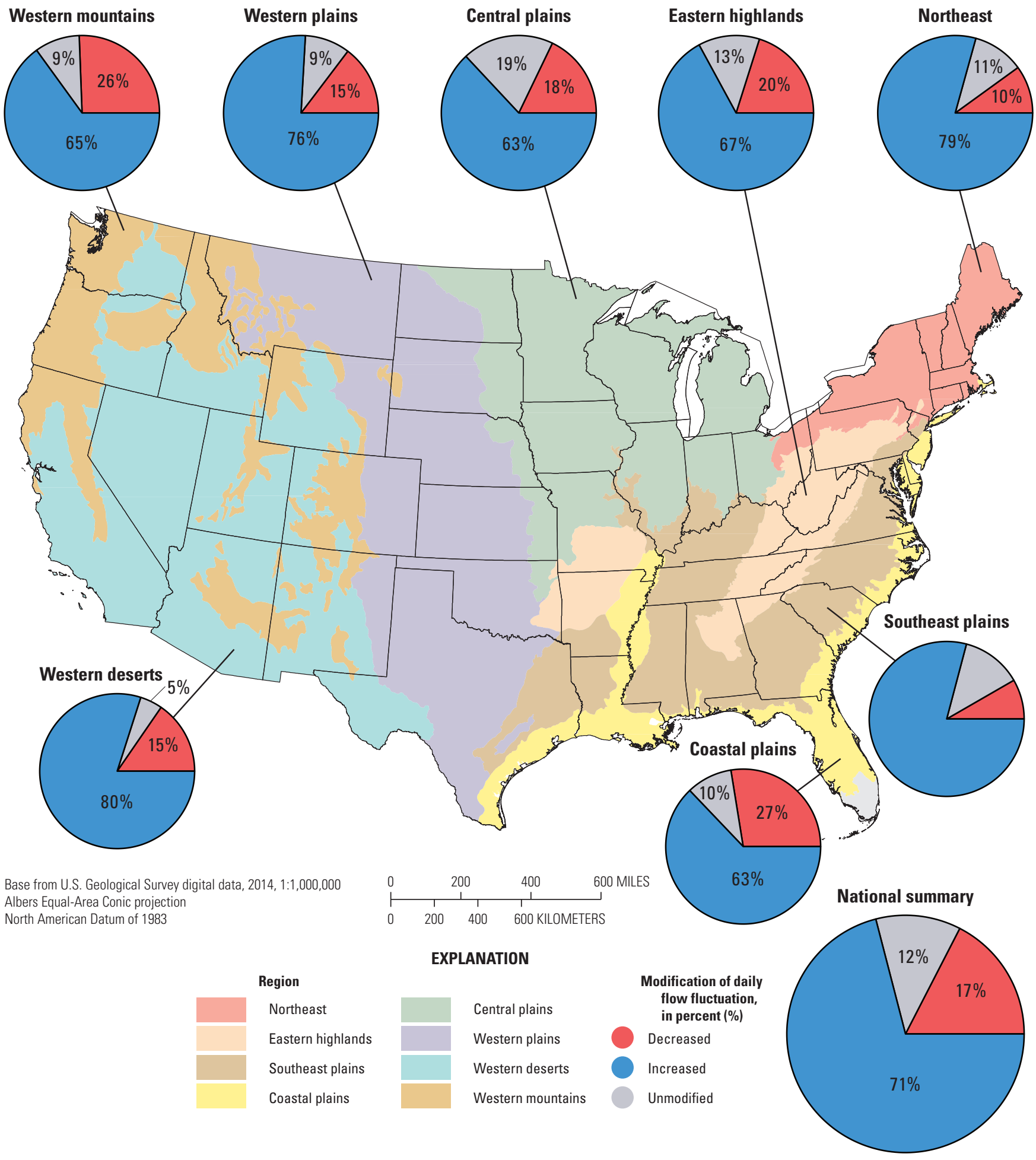

Figure B9. Regional summaries of the modification of daily flow fluctuation, categorized as being increased, decreased, or unmodified relative to natural conditions. Pie graphs show percentage of assessed U.S. Geological Survey streamgages in each region within each category of modification. 


\section{Predicting Flow Modification in the Nation's Streams and Rivers}

Monitoring flow at every stream and river in the Nation is not practicable, so there is a need to make predictions about flow modification for places that are not monitored. These predictions highlight where flow modification is likely and can therefore be used to prioritize additional monitoring activities in local areas but can also provide a national-scale illustration that reveals how widespread the issue of flow modification may be.

Information from monitored sites can be used to make predictions about the entire stream network, but with important caveats. First, measures of streamflow modification at monitored sites are combined with ancillary data about the stream network, including features that indicate human effects on streamflow. Next, these data are supplied to a statistical, machine-learning model that makes predictions to the entire network of streams and rivers (Eng and others, 2013). Because the network of monitoring sites is not representative of all the environmental conditions throughout the Nation's stream network, model predictions are extrapolations and must therefore be viewed with caution. In addition, data about human effects on streamflow, such as water use, are scarce and therefore reduce the accuracy with which the model identifies segments

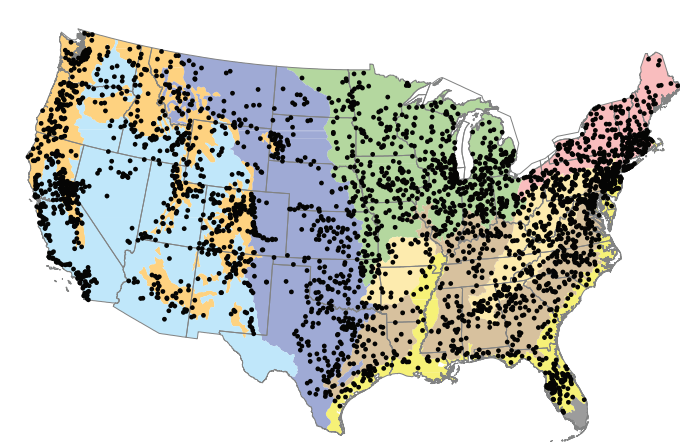

1. Monitored sites $+$

\section{Ancillary data}

- Stream network features

- Land use

- Water use

- Wastewater discharge

- Reservoir storage

with modified flows.

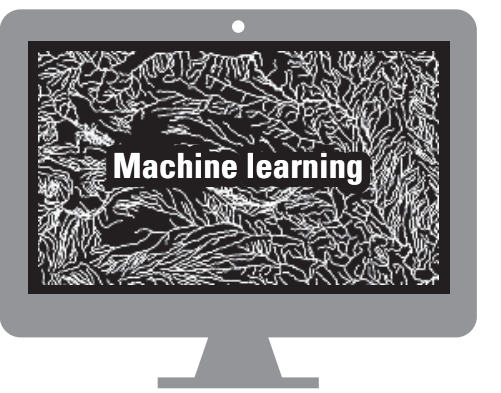

3. Statistical model

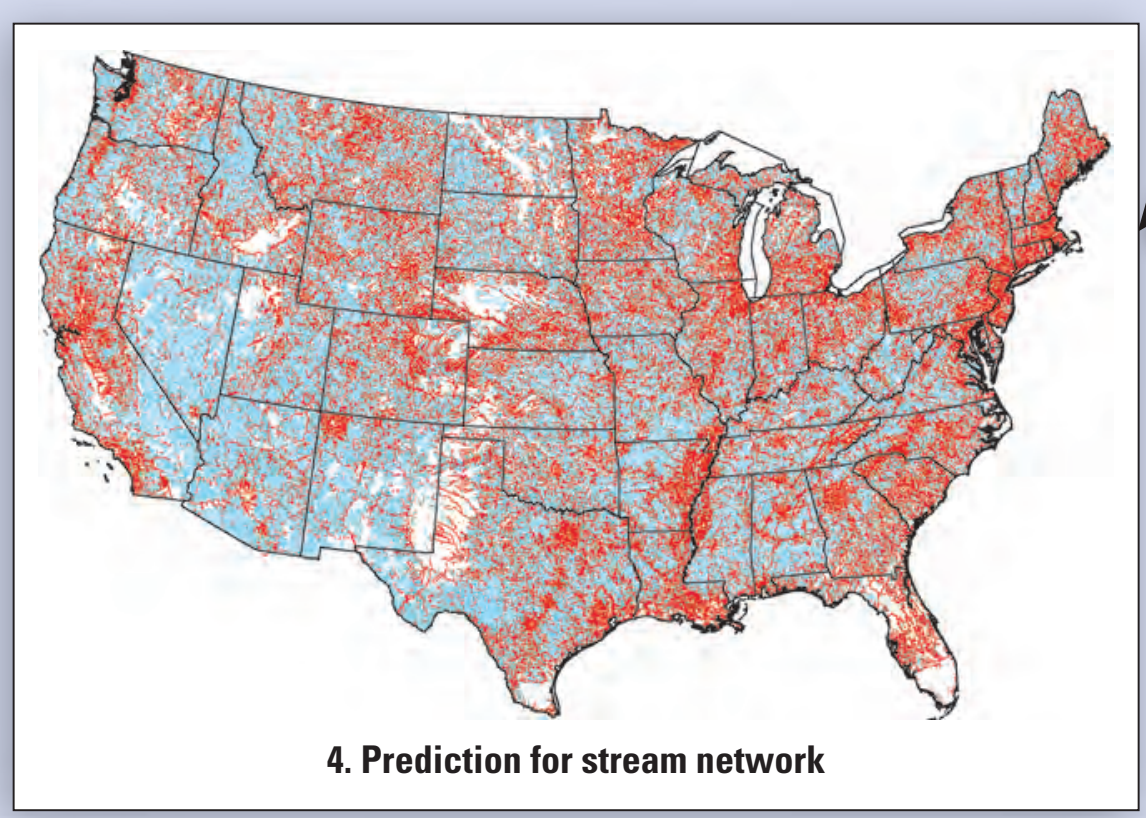

4. Prediction for stream network

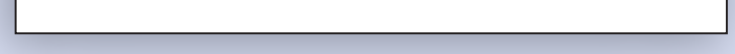

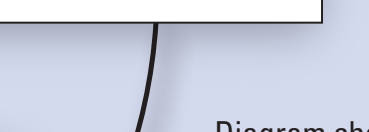

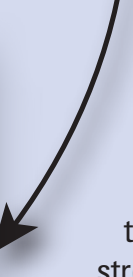

Diagram showing information from monitored sites (1) is combined with ancillary data (2) about the stream network and factors that indicate human effects on streamflow; then, it is supplied to a machine-learning model (3) to produce predictions about flow modification for the entire stream network (4). Predictions indicate that the natural patterns of streamflow of an estimated 1.2 million miles - more than one-third of the Nation's streams and rivershave been modified by land and water management. In this map of the entire network of streams and rivers in the contiguous United States, streams with modified flow are shown in red, and streams with natural flows are shown in blue. 


\section{Chapter C. Streamflow Modification Associated with Land and Water Management}

Humans, just like aquatic organisms, need water. Indeed, civilizations emerged where water was available (Macklin and Lewin, 2015). In modern times, humans have harnessed freshwater around the world for drinking, agriculture, industry, hydropower, and many other benefits. How do the ways we manage land and water affect the natural characteristics of streamflow that are required to maintain the health of ecosystems?

Understanding how human activities affect streamflows requires long-term (many decades) monitoring data in watersheds where human effects are minimal and in watersheds where those effects are substantial. Data that describe how that water is used also are essential. This information is compiled by several USGS programs and cooperators who maintain thousands of streamgages across the Nation.

The NAWQA Project assessed streamflow at more than 3,355 USGS streamgages and investigated how streamflow modification differed among watersheds with various types of land and water management, including reservoir, irrigation, row-crop, and urban settings. These broad categories were created to provide national-scale generalizations. Within each of these categories, however, a wide array of management practices and environmental settings likely have differing effects on streamflow (for example, Hopkins and others, 2015). These complexities are illustrated with specific case studies that are provided in addition to national-scale generalizations.

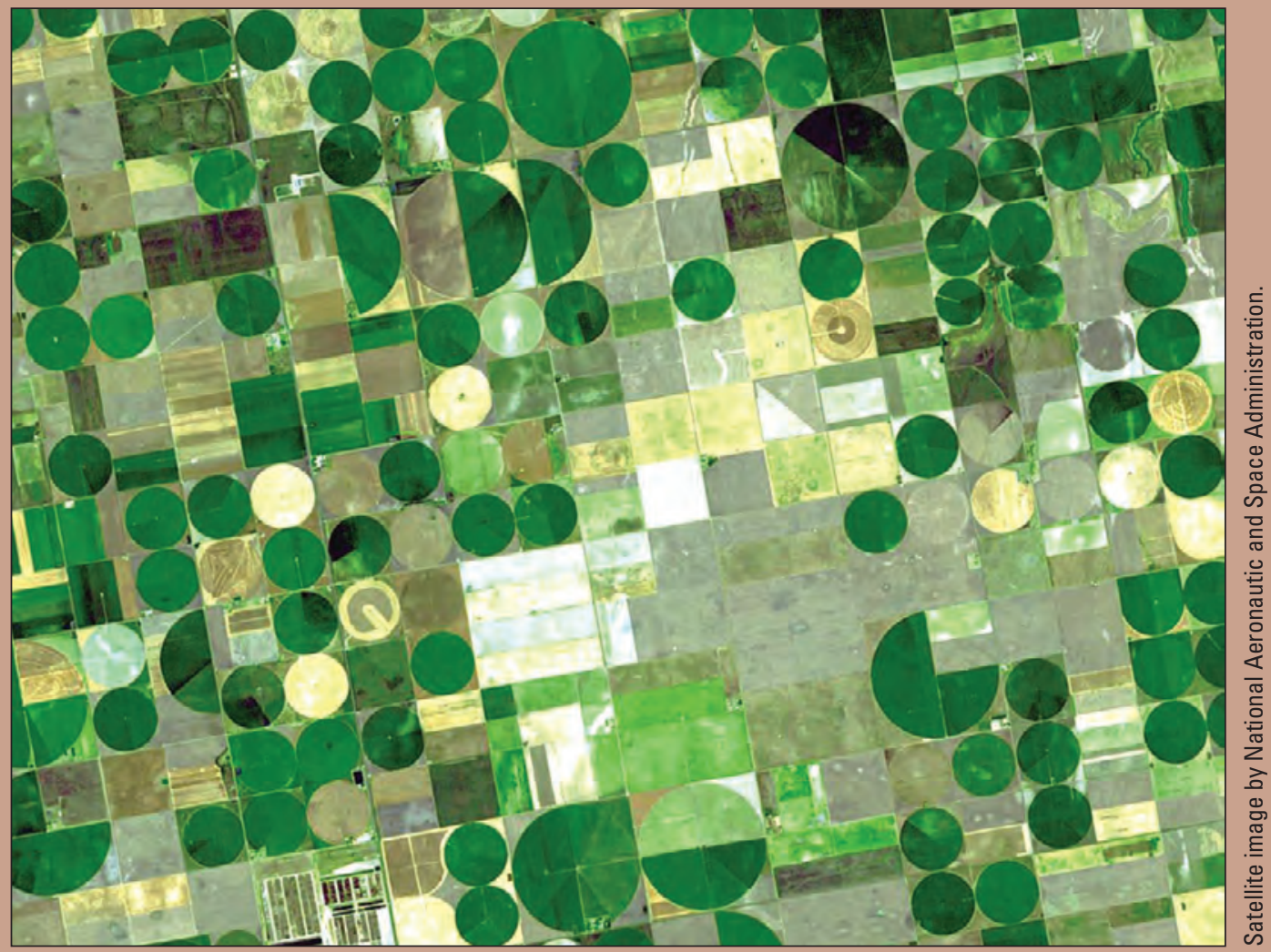

Water for irrigation is commonly pumped from the ground, which can deplete groundwater that is an important source of water to streams during dry weather. This National Aeronautics and Space Administration satellite image shows crop circles in Finney County, Kansas. These irrigated plots are 0.5 and 1 mile in diameter ( 800 and 1,600 meters). This area utilizes irrigation water from the 0 gallala aquifer, which underlies an area from Wyoming to Texas. 


\section{Categories of Land and Water Management}

Land- and water-management practices are difficult to measure and vary from region to region. To uncover broadscale patterns of streamflow modification among major types of land use practices, general categories were described based on information from land-use data, maps, and local expert knowledge. Assessed sites that fit into each of the four simplified categories were summarized to examine general patterns (Eng and others, 2019).

\begin{tabular}{|c|c|c|c|}
\hline Category & Upstream reservoir influence & Impervious land cover & Crops land cover \\
\hline Reservoir & Flow regulated by upstream dams & Variable & Variable. \\
\hline Irrigation & Minimal & $0-10$ percent of watershed & $\begin{array}{l}\text { Variable. Local knowledge reports irrigated } \\
\text { crop lands. }\end{array}$ \\
\hline Row crops & Minimal & $0-10$ percent of watershed & $\begin{array}{l}50-100 \text { percent of watershed. No reports of } \\
\text { irrigated crop lands. }\end{array}$ \\
\hline Urban & Minimal & $11-100$ percent of watershed & $0-50$ percent of watershed. \\
\hline
\end{tabular}

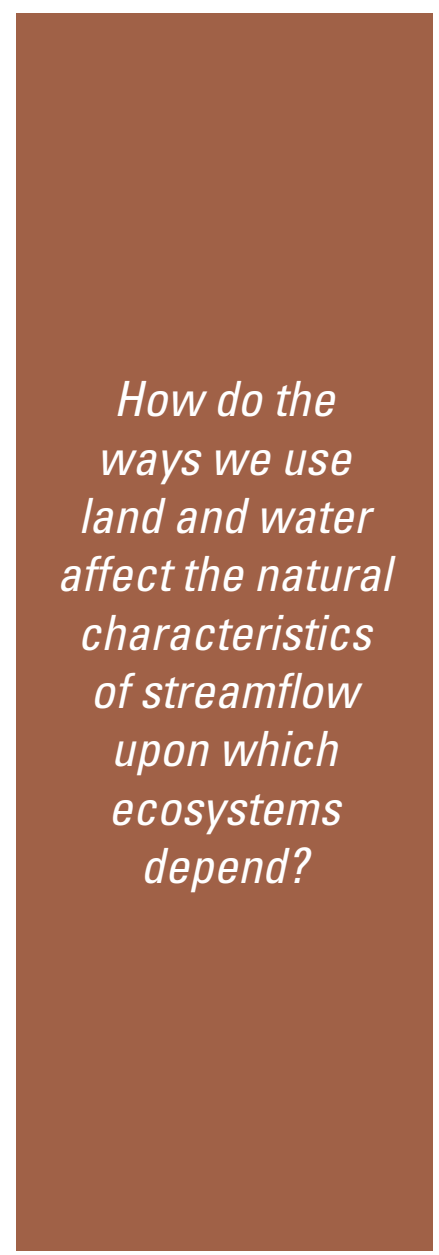

\section{Streamflow Magnitude}

Shallow groundwater is the most important water source for streams during periods of low flow. Human actions that change groundwater levels or the rate of groundwater recharge are therefore likely to affect low-flow magnitude in streams.

Across the Nation, the incidence of modified low flows was related to the type of land and water management (fig. C1). In urban settings, low-flow magnitude in most streams was higher than natural. This likely is because shallow groundwater in some urban areas receives additional recharge from leaky water infrastructure and residential irrigation, although the relative effect of these factors is probably related to the age of the urban infrastructure and the climate (Walsh and others, 2005). In contrast, in irrigated agricultural settings, low flows in most streams were lower than natural. This is likely because water needed for irrigation during dry weather-when flow is usually low - is typically diverted directly from streams or pumped from shallow groundwater, further lowering flows (Bunn and Arthington, 2002). In reservoir and row-crop settings, streams with lower or higher than natural low flows were common, which suggests that different management practices in these settings can lead to a variety of streamflow modifications.

The incidence of modified high flows was also related to the type of land and water management (fig. C1). High flows in streams are fed by rain and snowmelt, which can cause destructive floods in some situations. Structures that are built to reduce flooding by diverting or storing high flows reduce high-flow magnitudes. Reservoirs designed for other purposes, such as drinking-water supply, also can reduce high-flow magnitude (Graf, 2006). Other structures are designed to divert some part of streamflow to use for irrigation, reducing the magnitude of high flow. In row-crop agricultural settings, thousands of ponds have been constructed in headwater areas to capture eroded sediment and runoff; these ponds can retain substantial amounts of water during high-flow events, reducing high-flow magnitude. In contrast, high-flow magnitudes in urban streams are often higher than natural because of impervious (hard) surfaces, such as pavement and rooftops. Rainfall that falls on impervious surfaces runs off to streams rather than infiltrating into the ground, causing high flow that is greater than would occur under natural conditions. 


\section{Low-flow magnitude was higher than} natural in streams in urban settings and lower than natural in streams in irrigated areas.

\section{High-flow magnitude was lower than} natural in most streams except for those

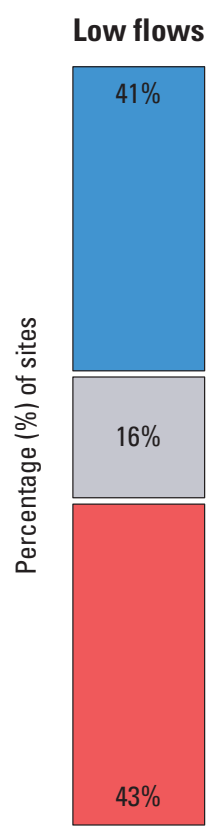

All sites

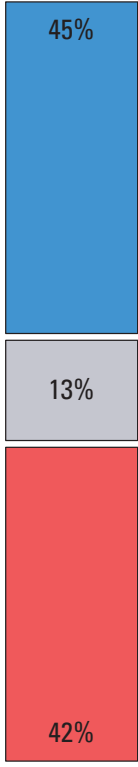

Reservoir

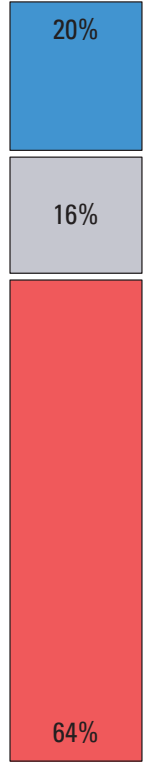

Irrigation

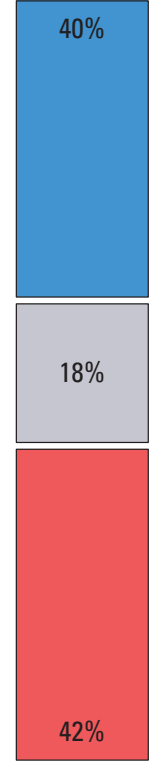

Row crops

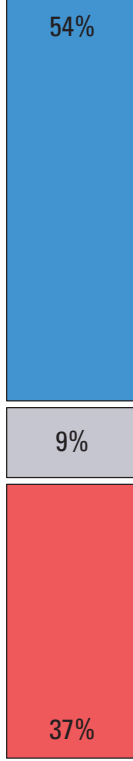

Urban
High flows

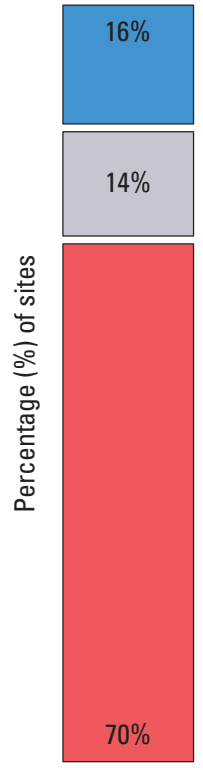

All sites

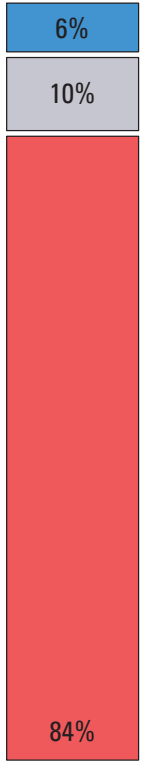

Reservoir

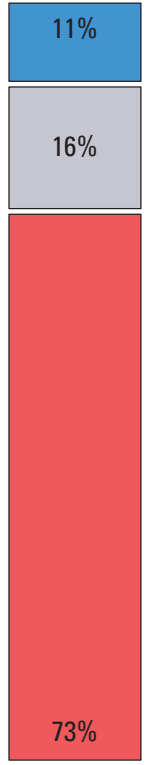

Irrigation

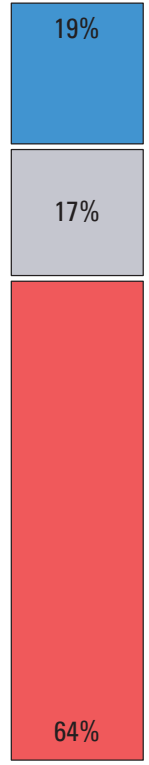

Row crops

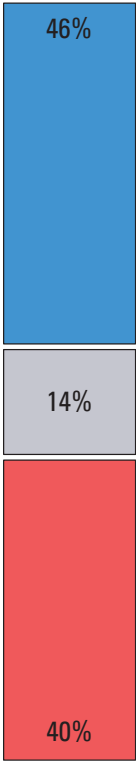

Urban

\section{EXPLANATION}

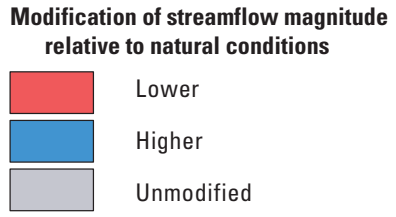

Figure C1. How streamflow magnitude was modified in relation to land and water management. Each assessed streamgaging site is categorized based on the type of land and water management predominant in its watershed. Modification of streamflow magnitude is categorized as lower, higher, or unmodified relative to natural conditions. Percentages of assessed streamgaging sites in each category are given. For comparison, streamflow modification at all assessed streamgaging sites, nationwide, also is shown. 


\section{Urbanization Transformed a Naturally Intermittent Stream into a Perennial One}

Under natural conditions, lowflow magnitude in Cucamonga Creek, California, typically ranged from 1 to 10 cubic feet per second, and sometimes there was no flow at all- the stream was intermittent. In the late 1970s, the watershed began to urbanize and the creek started to be channelized, and in the mid-1980s, treated wastewater began to be discharged regularly into the creek. As a result, low-flow magnitudes now are more than 10 times what they were, and the stream flows continuouslyreferred to as perennial flow. Transformation of a stream with intermittent flow to one with perennial flow dominated by wastewater radically changes aquatic habitat conditions and the types of organisms that live there.
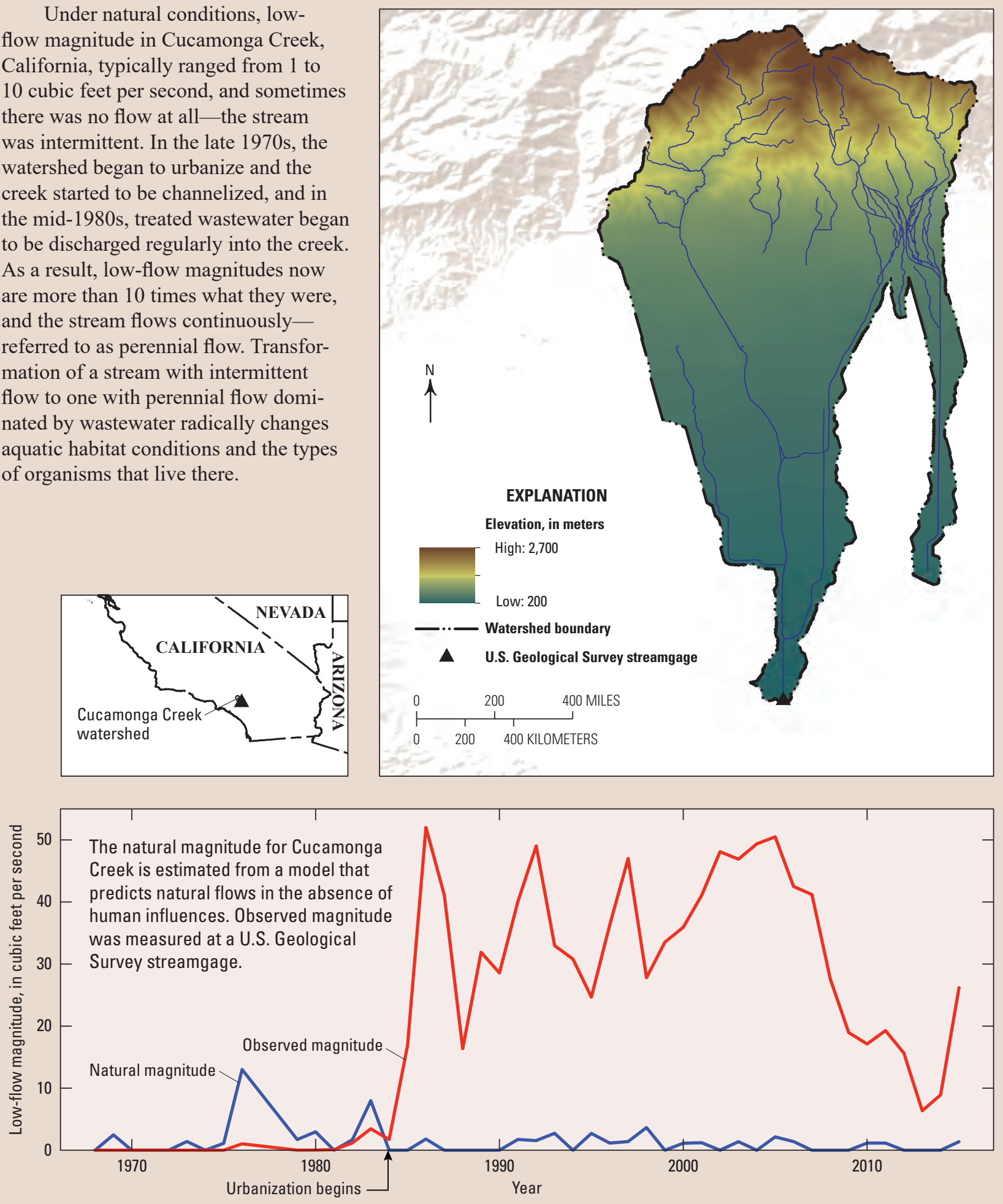


\section{Many Dams Are Constructed Primarily for Flood Control and Therefore Have Dramatic Effects on the Magnitude, Frequency, and Duration of High Flows}

In the early 20th century, the Sacandaga River, in the Adirondacks Mountains of New York, contributed to flooding in several downstream communities including Albany, the State capitol. To control the floods, a dam was built upstream at Conklingville. The dam, which began operations in 1930, dramatically decreased the magnitude of annual high flows. Before dam construction, the annual high-flow magnitude averaged 16,000 cubic feet per second, but since dam construction, it has averaged only 6,000 cubic feet per second. In most years, the entirety of high flows is held within the reservoir; that is, no surplus water passes over the dam spillway. The magnitude of high flows each year is almost always under complete human control.
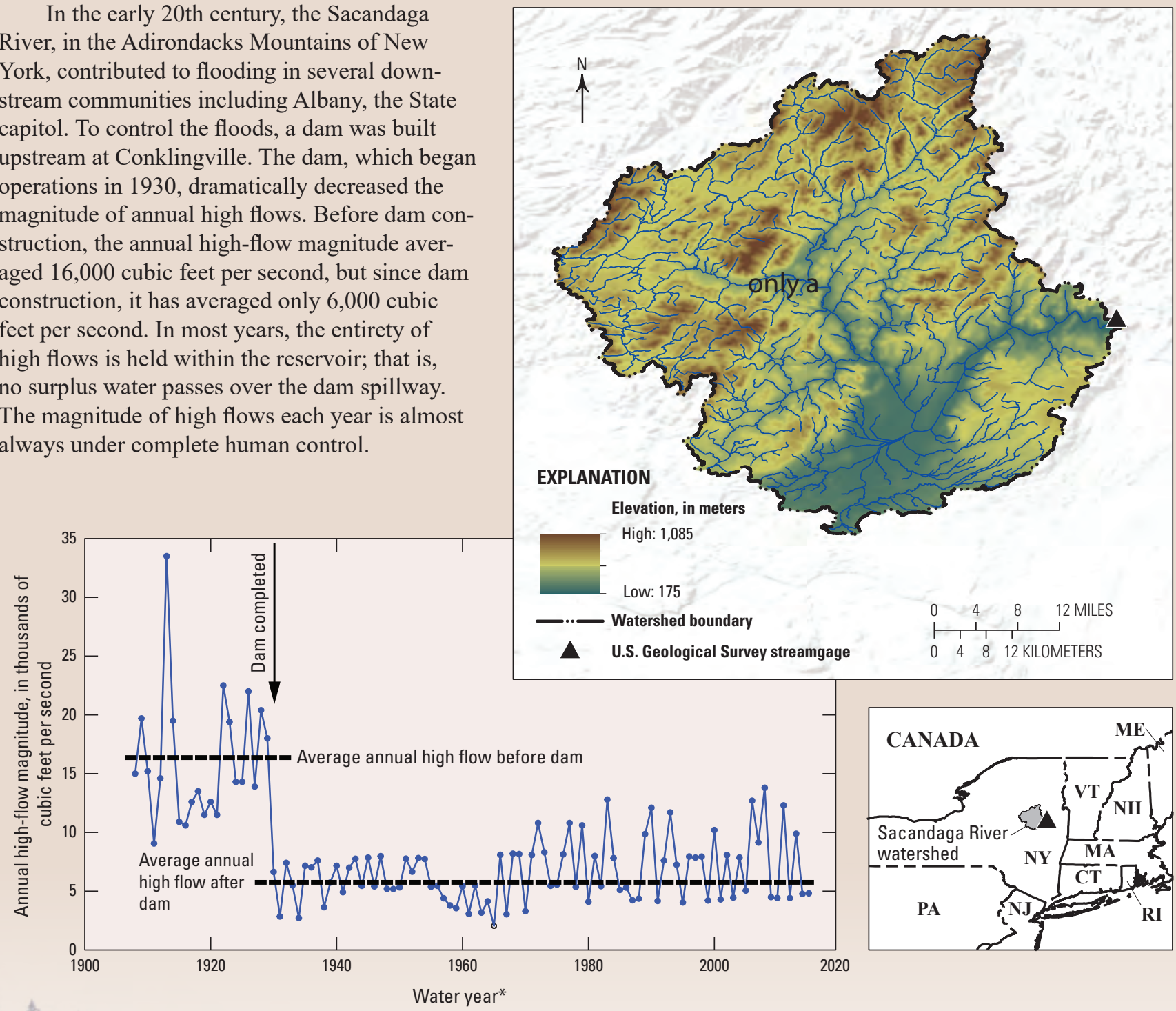

${ }^{*}$ A water year is the period from October 1 to September 30

and is designated by the year in which it ends.

Conklingville Dam on the Sacandaga River in New York. Photograph by National Weather Service.

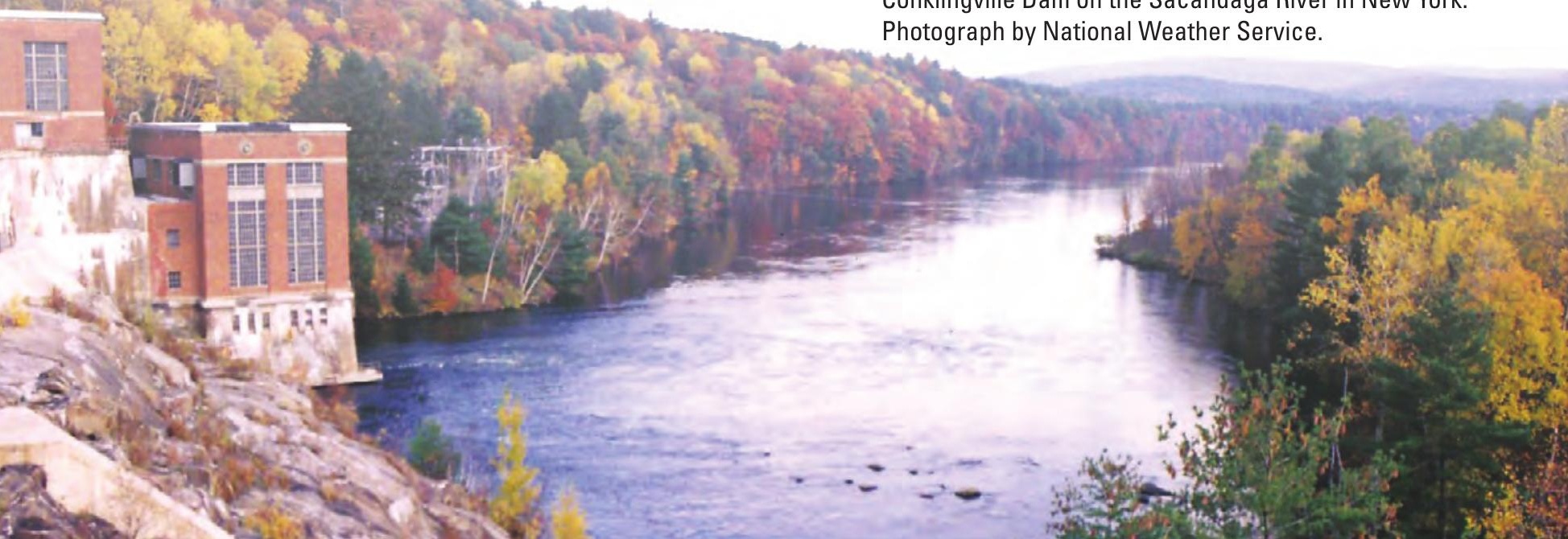




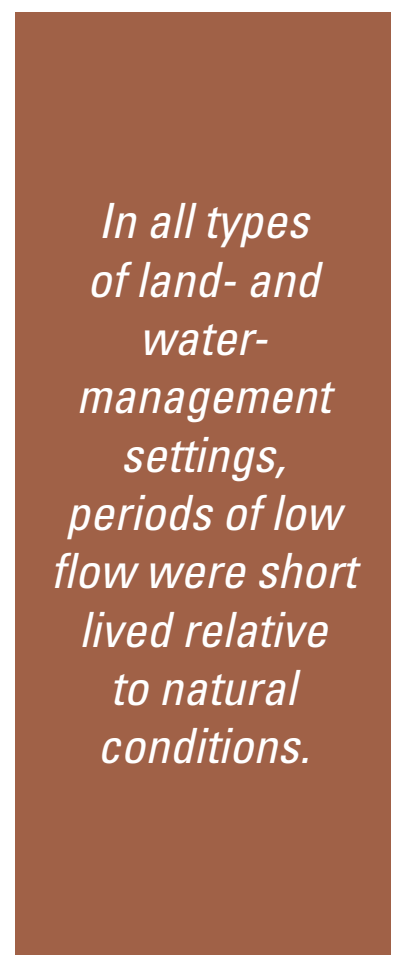

\section{Streamflow Duration}

Across the Nation, modification of streamflow duration was related to land and water management (fig. C2). Under natural conditions, the duration of low flows is sustained by groundwater inputs to the stream. These periods of low flow can be interrupted, however, by water-management practices such as reservoirs and diversions that release excess water into streams. Low flows in urban and agricultural settings can be interrupted by precipitation events that, under natural conditions, would not have caused streamflow to rise; for example, in urban settings, natural vegetation is replaced by impervious surfaces such as roads and parking lots that prevent precipitation from infiltrating into the ground. Instead, the precipitation is rapidly delivered to streams, which causes abrupt increases in streamflow, even when a rainfall event is relatively minor.

Under natural conditions, high streamflows are associated with snowmelt or precipitation events and typically recede gradually because natural vegetation and groundwater absorb excess precipitation to be released slowly later. In reservoir and row-crop settings, most streams experienced high flows for a longer duration than what is natural. Reservoirs typically store excess flow from high-flow events and subsequently release excess water over a prolonged period, which causes a period of high flows that is longer in duration than natural. Croplands in many areas are poorly drained, which causes rainfall to accumulate in soils and slowly seep into nearby streams, which tends to prolong high-flow events. In contrast, the duration of high flows was shorter than natural in most streams affected by urban and irrigation settings. In urban areas, impervious surfaces decrease infiltration and increase runoff rates, which causes more frequent but shorter duration high-flow events (Bonneau and others, 2017). In arid irrigation settings, the duration of high flows is commonly reduced by diversions during spring and summer.

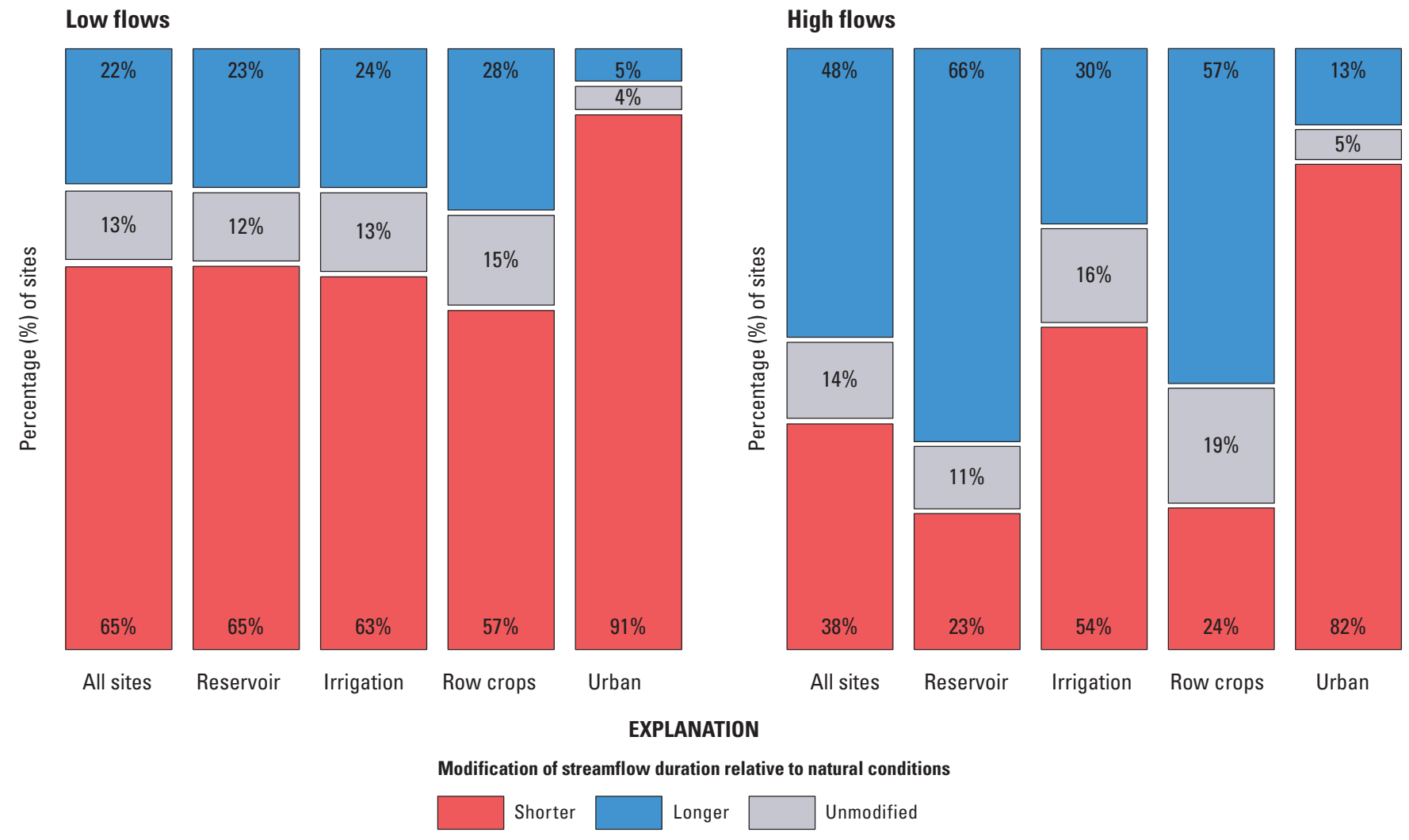

Figure C2. How streamflow duration was modified in relation to land and water management. Each assessed streamgaging site is categorized based on the type of land and water management predominant in its watershed. Modification of streamflow duration is categorized as shorter, longer, or unmodified relative to natural conditions. Percentages of assessed streamgaging sites in each category are given. For comparison, streamflow modification at all assessed streamgaging sites, nationwide, also is shown. 


\section{Groundwater Pumping and Drought Have Caused Low Flows to Become More Frequent and Last Longer in a Western Plains Stream}

Drought is a natural and regular phenomenon in the Great Plains. Remarkably, however, streams like the Arikaree River in Colorado continue to flow during droughts because they are fed by groundwater from deep aquifers. The Arikaree River is highly valued as a natural area because it supports rich ecological diversity (Colorado Parks and Wildlife, 2012).

Since the 1950s, groundwater pumping for irrigation in the Arikaree River Basin has increased more than 400 percent. Because groundwater is a major source of water for streamflow - particularly during droughts - the increase in groundwater withdrawal has been accompanied by a steady drop in streamflows in the Arikaree River (Falke and others, 2010). The decline in streamflows because of groundwater depletion was most pronounced during a drought that began in 2000. Prolonged periods of low flow often cause long stretches of the river to become dry, which interrupts the continuity of usable habitat for fish. As of 2017, nearly half of the Arikaree River's 16 native fish species have been entirely eliminated primarily because of streamflow modification (Perkin and others, 2017).
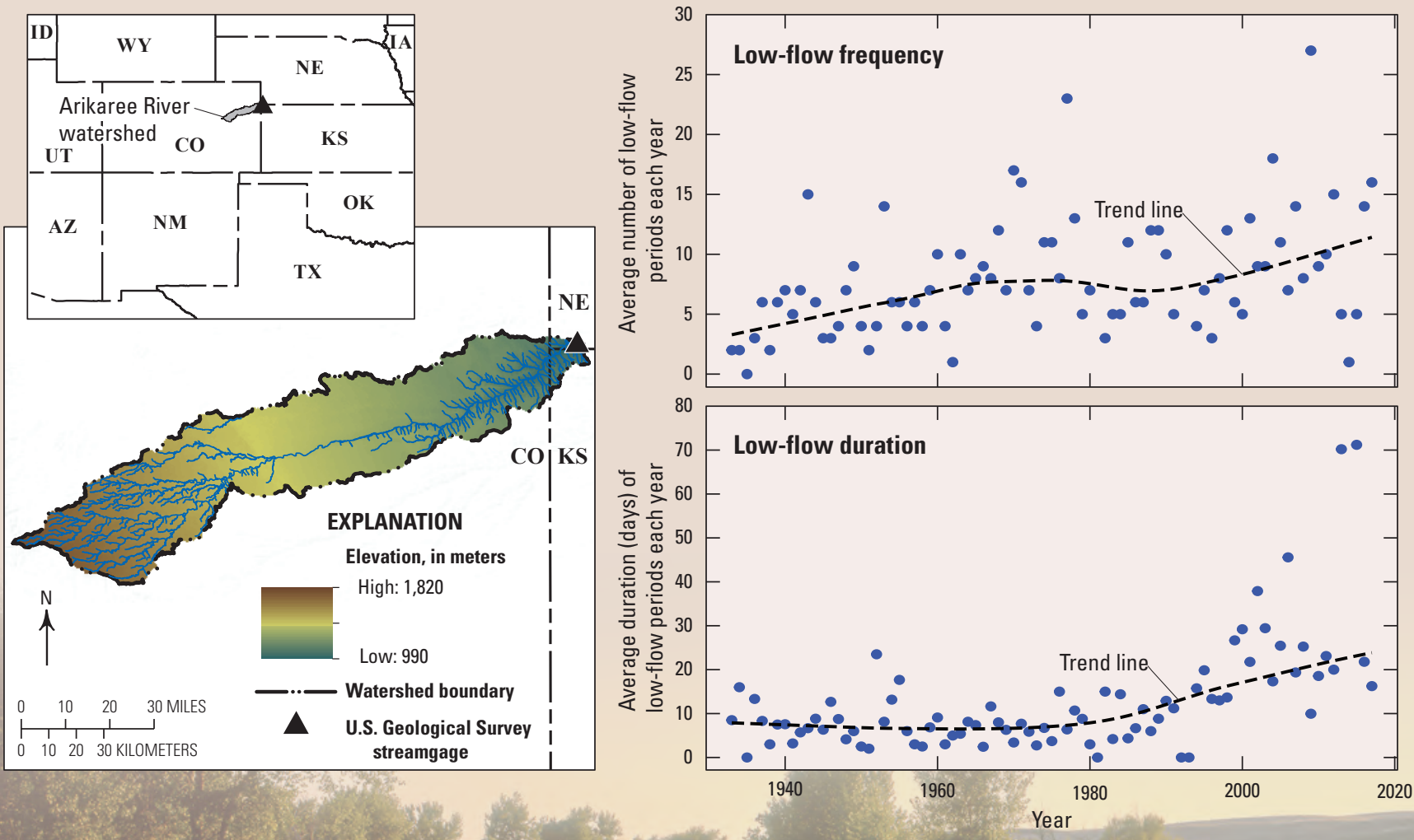


\section{Reservoir Operations Commonly Reduce the Duration of Low Flows in Downstream Rivers}

The Flathead River originates in the Canadian Rockies; flows into Flathead Lake, Montana; and eventually flows into the Columbia River. The Flathead River is designated as a National Park Service Wild and Scenic River and is well known for its recreation and scenic beauty.

The Kerr Dam, now known as the Seli's Ksanka Qlispe' Dam, was built for power generation and recreation and was completed in 1930. The dam impounded the river where it flows out of Flathead Lake. Flathead Lake was a natural lake, but the dam substantially increased its size.

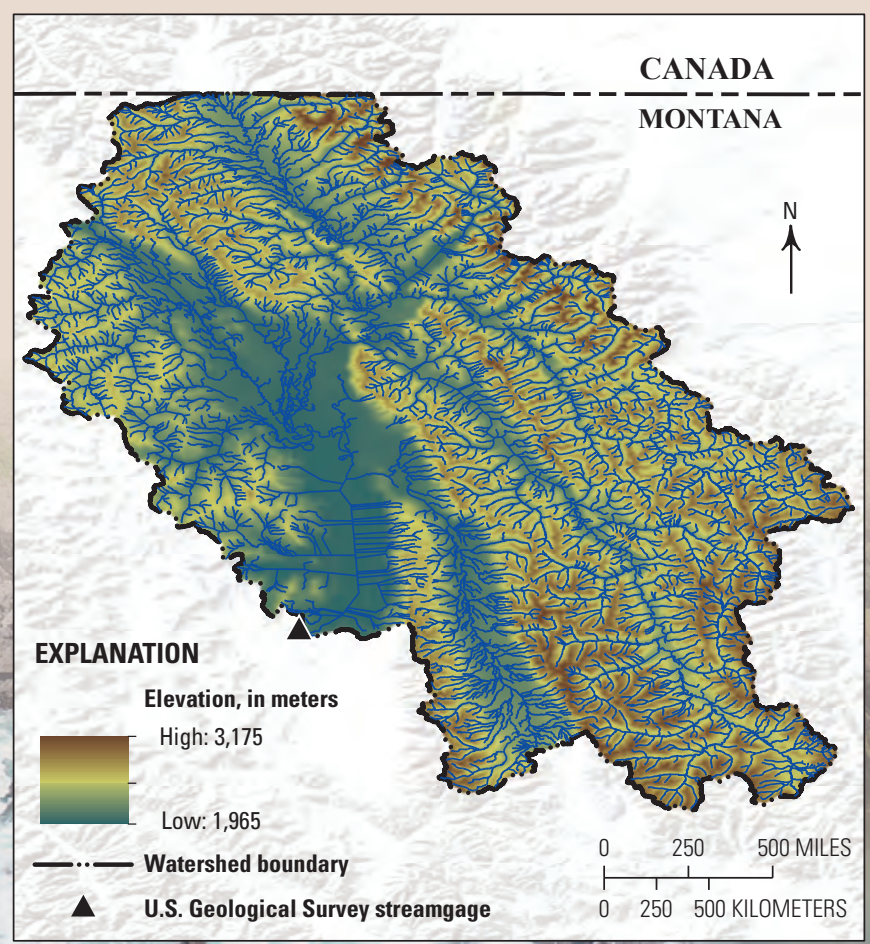

gurvey streamgage
Before the dam was built, periods of low flow each year averaged 23 days in length, and on at least one occasion exceeded 100 days. After completion of the dam, the average length of low-flow periods decreased to 7 days. Since 1985, flows in the Flathead River have been consistently above levels that are considered low, based on longterm estimates of natural conditions. In essence, natural low flows no longer occur in the Flathead River. Because low flows are critical to the life cycles of aquatic species, elimination of low flows likely poses a risk to species unable to adapt. Despite this drastic change in low-flow duration, little is known about how this modification may have affected the myriad species, such as native Oncorhynchus clarki (cutthroat trout), that call the Flathead River home.
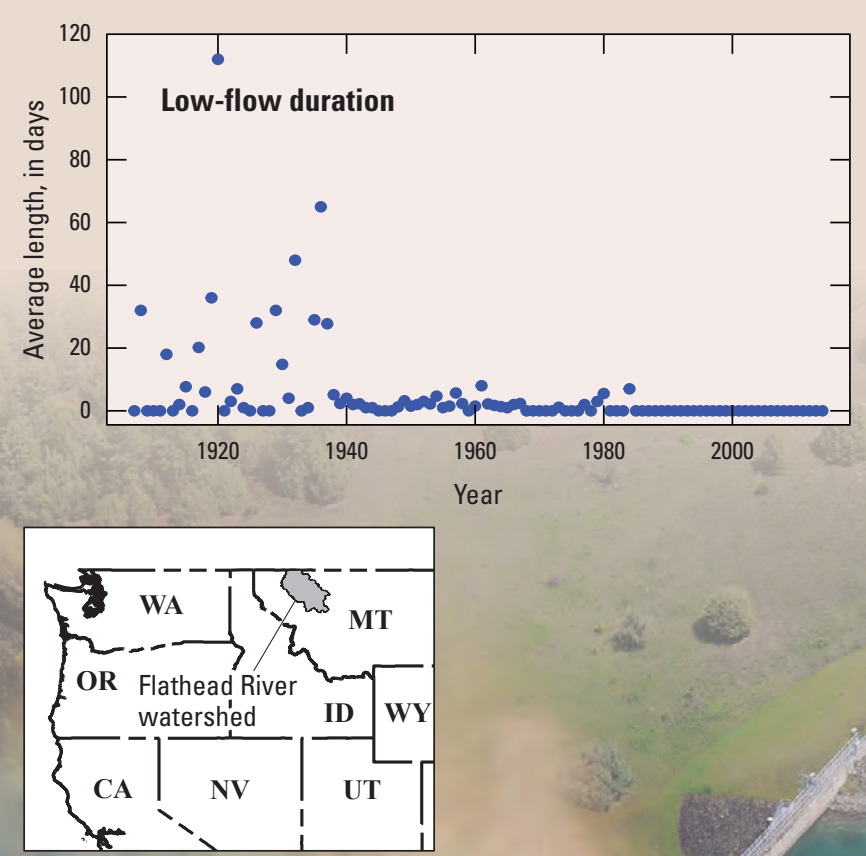
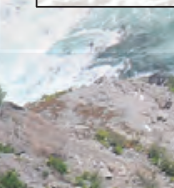

2. Kerr Dam on the Flathead River, Montana. Photograph by

4. Larry Mayer, staff photographer/Billings Gazette. Used with permission. 


\section{Streamflow Frequency}

The ways in which streamflow frequency was modified depended on the type of land and water management (fig. C3). Under natural conditions, streams experience low flows when groundwater becomes the dominant source of water, which is common during dry weather but also can occur during winter if precipitation falls primarily as snow-until it melts, snow does not provide water for streamflow. The frequency of low flows is therefore highly affected by climatic conditions in addition to other natural factors such as vegetation and geology. Most land- and water-management actions can cause low flows to be more frequent relative to natural conditions. Direct manipulation of streamflow with dams and diversions typically results in flow reductions that are unrelated to the natural climatic setting. In most developed land-use settings, streamflows often fall to low levels more quickly than they would naturally because of the removal of vegetative land cover that dampens flow fluctuations.

Under natural conditions, high streamflows follow large storms or melting of accumulated snowpack. In urban areas, high flows are more frequent than they would be naturally because soil and vegetation, which allow rainfall to soak into the ground, have been replaced by impervious surfaces, such as roads and rooftops. In contrast, streams downstream from reservoirs tend to have less frequent high flows because much of the water is held back by the reservoir. Local conditions or specific management practices, however, also can affect how frequent high flows occur; for example, sediment- or stormwater-retention ponds can hold back water, which decreases the frequency of high flows.
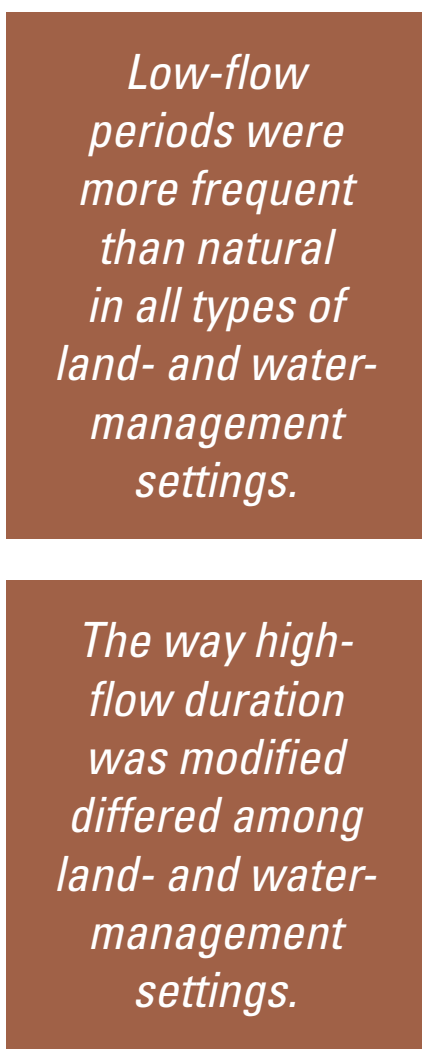

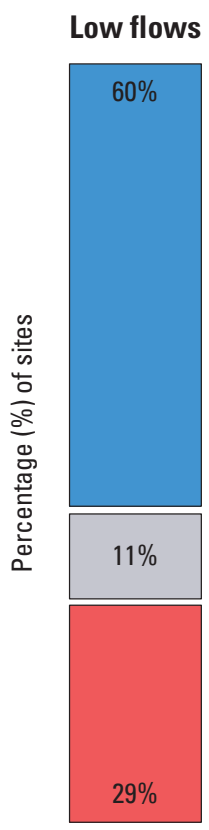

All sites

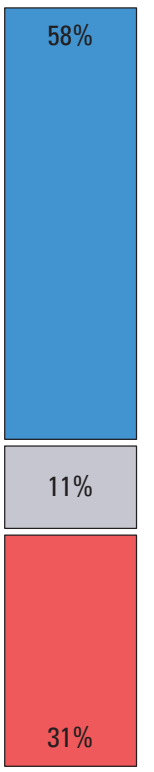

Reservoir

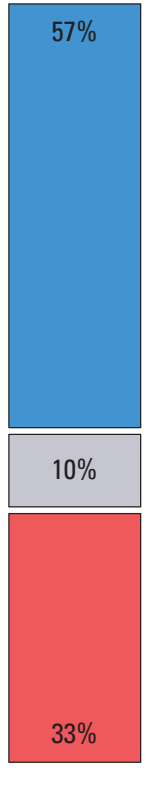

Irrigation

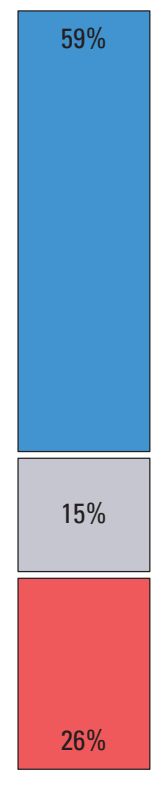

Row crops

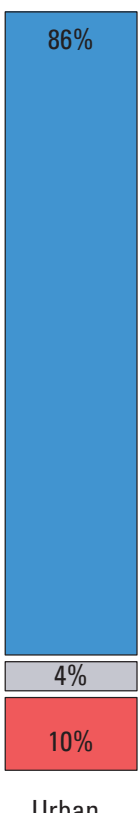

EXPLANATION
High flows
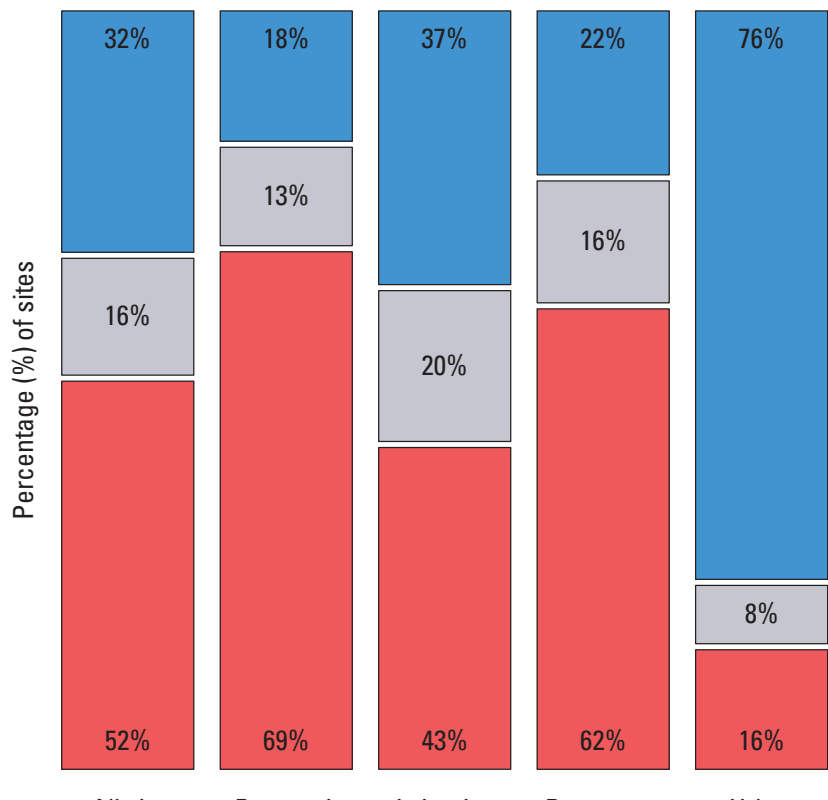

All sites

Reservoir
The way high-

differed among land- and water-

management

settings.

Modification of streamflow frequency relative to natural conditions

Decreased

Increased

Unmodified

Figure C3. How streamflow frequency was modified in relation to land and water management. Each assessed streamgaging site is categorized based on the type of land and water management predominant in its watershed. Modification of streamflow frequency is categorized as decreased, increased, or unmodified relative to natural conditions. Percentages of assessed streamgaging sites in each category are given. For comparison, streamflow modification at all assessed streamgaging sites, nationwide, also is shown. 


\section{Local Differences in the Way Watersheds Urbanize Can Lead to Divergent Effects on High-Flow Frequency}

Roads, parking lots, and other impervious surfaces that accompany urbanization reduce the amount of precipitation (rain and snowmelt) that infiltrates into soils and groundwater. Precipitation therefore quickly runs off the impervious surfaces and into nearby streams, causing an unnaturally high frequency (and magnitude) of high flows. There are, however, intervening factors that can affect this pattern.

For example, two adjacent watersheds in northern Virginia-Accotink Creek and Difficult Run - began to urbanize in 1950. Although high-flow frequency (measured with an index of streamflow variability) was similar for the two streams in 1950 , this similarity soon began to change. Over the next six decades, high-flow frequency in Accotink

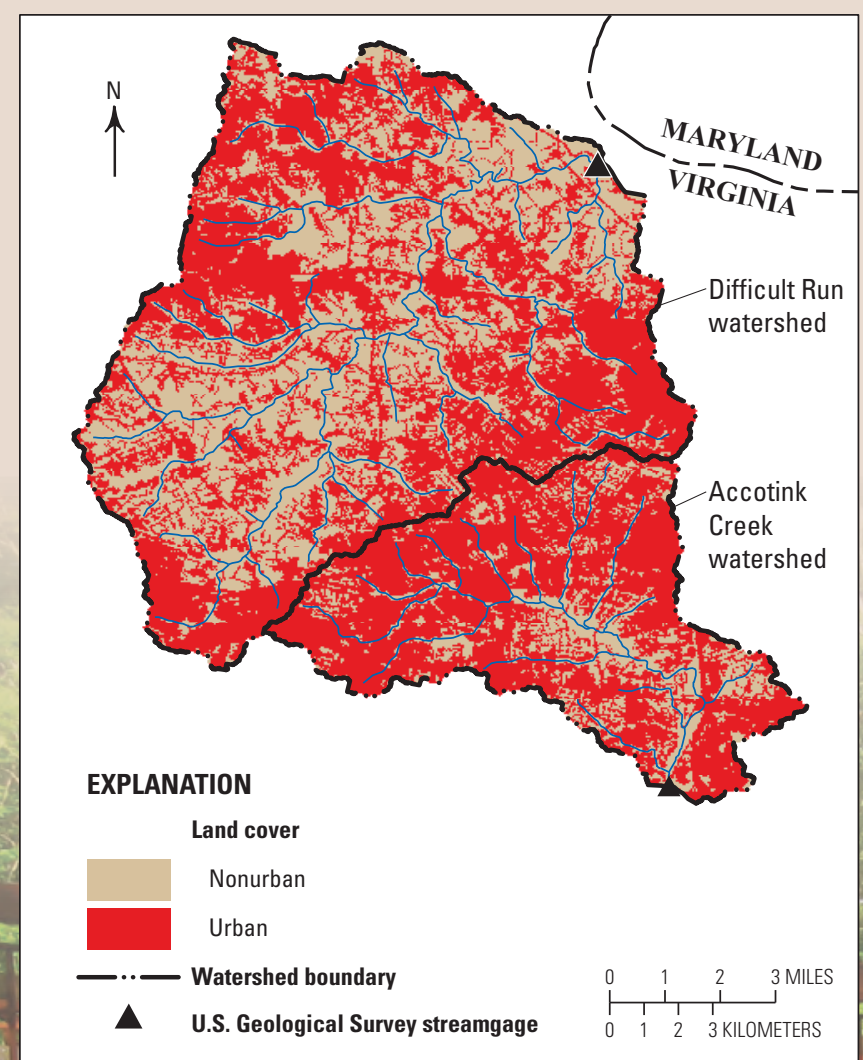

Creek increased 400 percent, but high-flow frequency in Difficult Run remained largely unchanged. The major differences between these watersheds is that the density of urban development is two times higher in Accotink Creek than in Difficult Run, which also has several small reservoirs in the headwaters that mitigate urban runoff. The major differences between these watersheds are that the density of urban development is two times higher in Accotink Creek than in Difficult Run, Difficult Run has several small reservoirs in the headwaters that mitigate urban runoff, and the watershed of Accotink Creek is half the size of the Difficult Run watershed. These three factors all affect high-flow frequency.
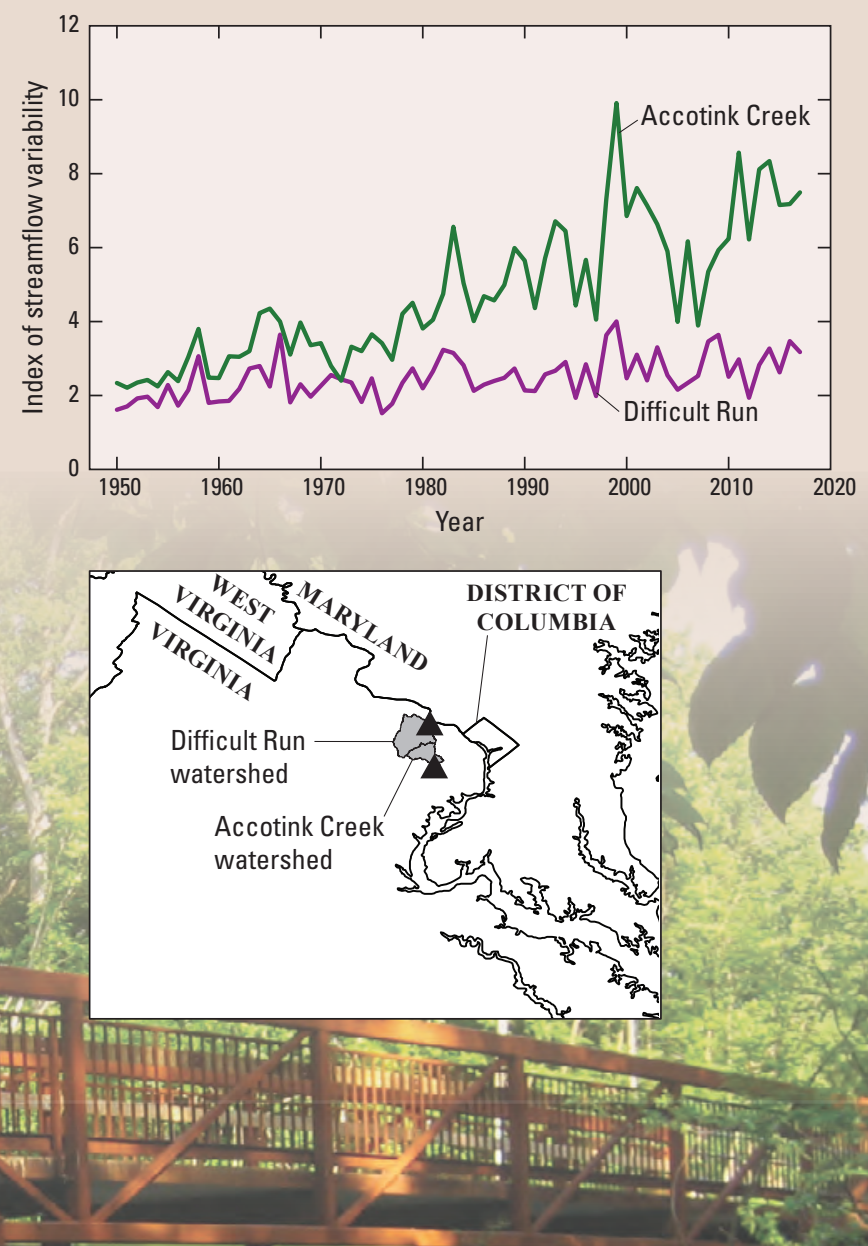

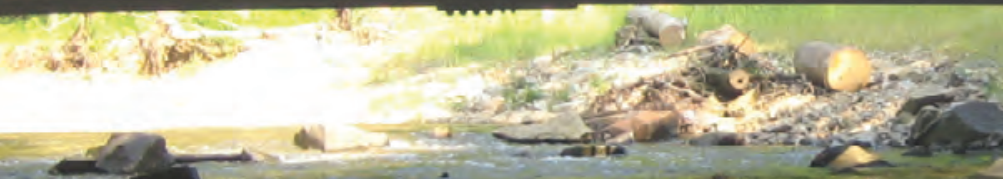

Trail bridge over Accotink Creek. Photograph from Wikimedia Commons, Creative Commons Attribution-Share Alike 2.0 Generic license. 


\section{Annual Variability of Streamflow}

Under natural conditions, year-to-year variation of flow magnitude is controlled primarily by differences in precipitation, but humans tend to manage water in ways that reduce this variability (fig. C4). For example, reservoirs typically reduce high flows each year by retaining water that is released later, usually during periods of naturally low flows. This practice has the effect of dampening year-to-year variation in high- and low-flow magnitudes. Similarly, low flows in urban settings are often generated by wastewater releases or groundwater augmented by domestic irrigation and leaking infrastructure such as sewer and water systems. As a result, year-to-year variability in low-flow magnitude in urban streams is much less related to precipitation than in natural systems and is therefore less variable. In contrast, some land- and watermanagement practices can increase the annual variability of low- or high-flow magnitude. Lowflows can become increasingly variable from year to year if a constant volume is withdrawn for irrigation regardless of the natural year-to-year variation in flows. Particularly during dry years, water withdrawals can exacerbate periods of extremely low flow, which would lead to greater year-to-year fluctuations than under natural conditions.

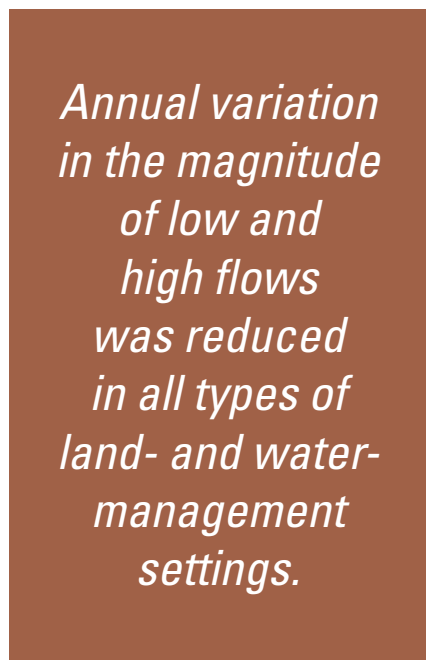

\section{Low flows}

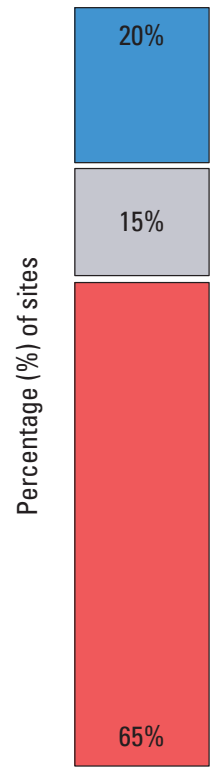

All sites

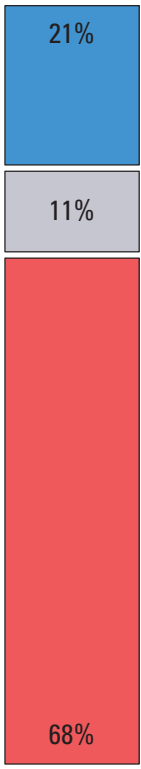

Reservoir

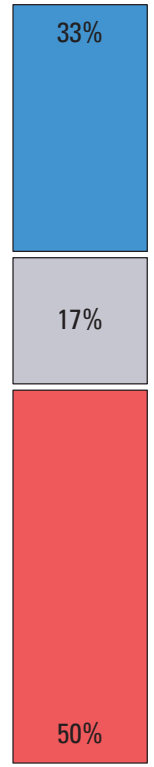

Irrigation

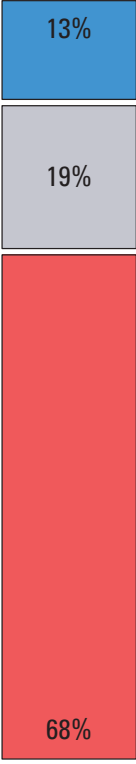

Row crops

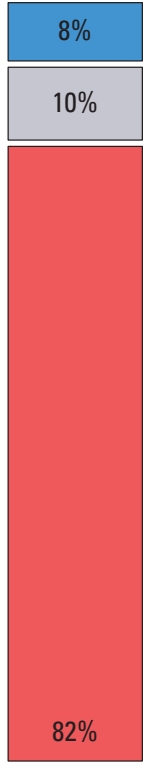

Urban
High flows

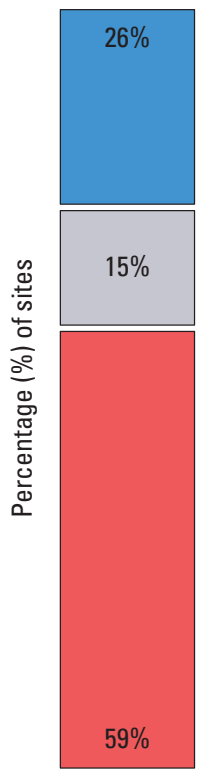

All sites

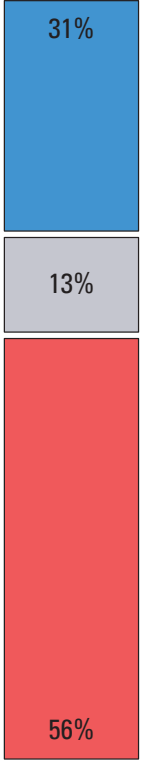

Reservoir

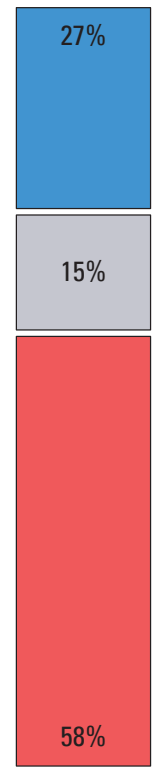

Irrigation

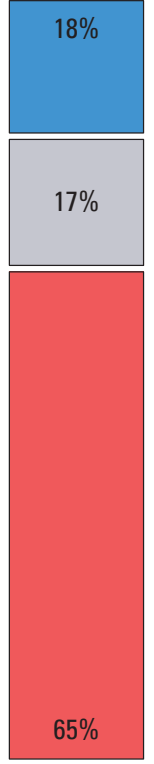

Row crops

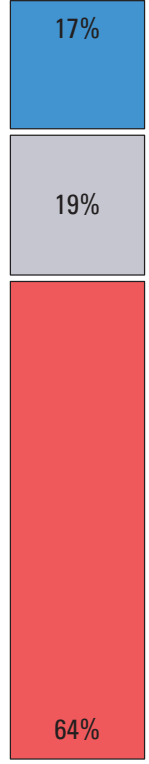

Urban

EXPLANATION

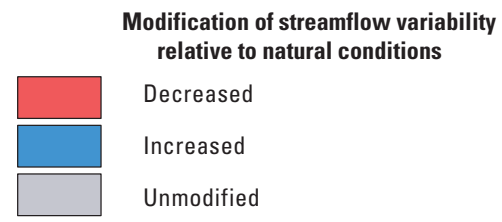

Figure C4. How annual variability of streamflow was modified in relation to land and water management. Each assessed streamgaging site is categorized based on the type of land and water management predominant in its watershed. Modification of streamflow variability is categorized as decreased, increased, or unmodified relative to natural conditions. Percentages of assessed streamgaging sites in each category are given. For comparison, streamflow modification at all assessed streamgaging sites, nationwide, also is shown. 


\section{Reservoirs Commonly Reduce the Annual Variation of High Flows}

The Delaware Dam was constructed on the Olentangy River, Ohio, by the U.S. Army Corps of Engineers in 1951 for the primary purpose of flood control. For the years before dam construction, the magnitude of high flows (measured as the maximum daily flow each year) varied from about 3,000 to 12,000 cubic feet per second. Over the last 40 years, however, high-flow magnitude varied from about 3,000 to 5,000 cubic feet per second. The dam has effectively reduced flood risk and provided water supply and recreational opportunities, but the benefits of natural annual variability to the downstream ecosystem have been lost.
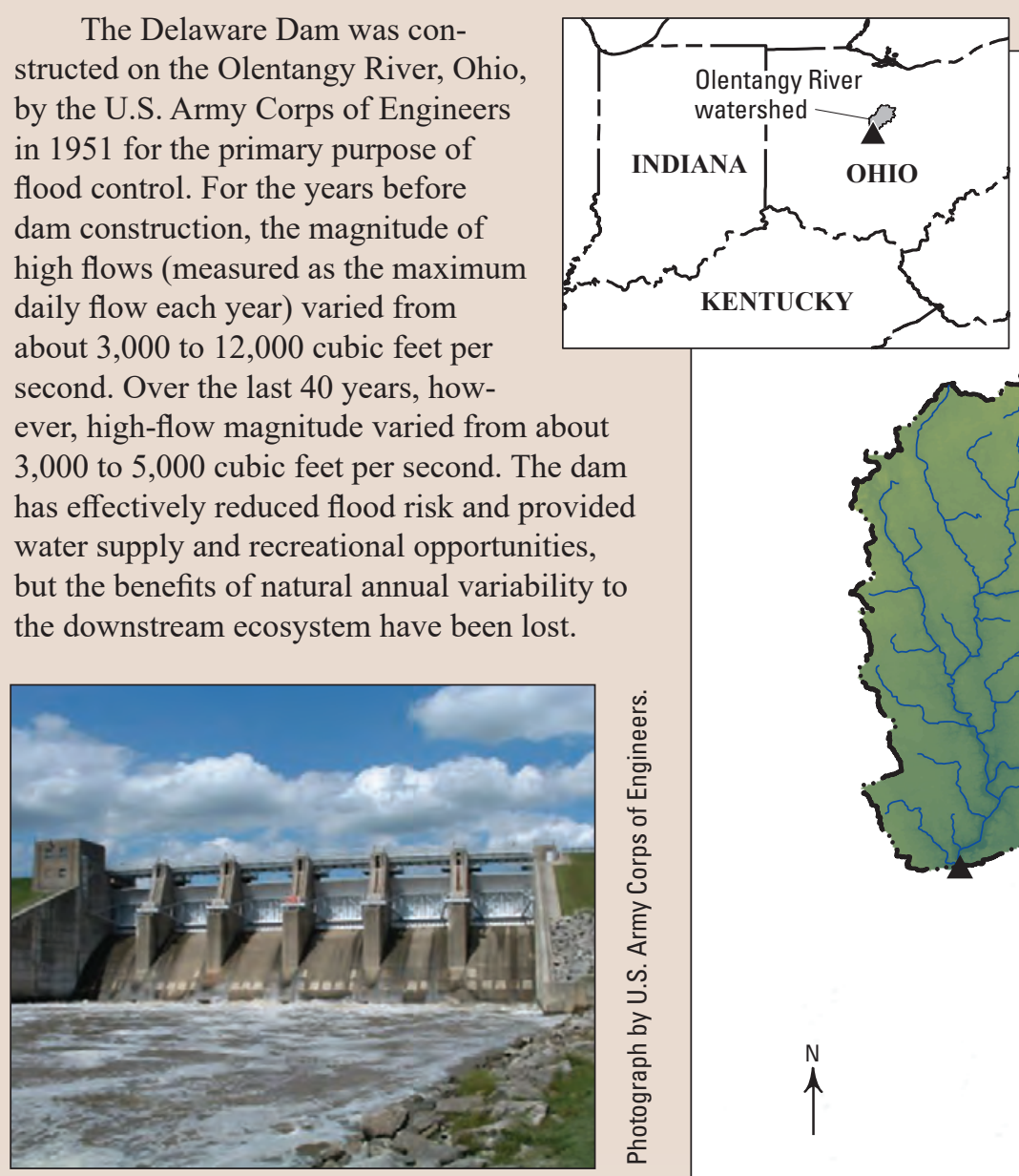

Delaware Dam on the Olentangy River in Ohio.

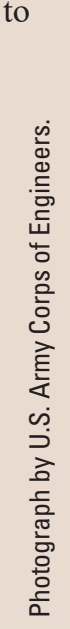

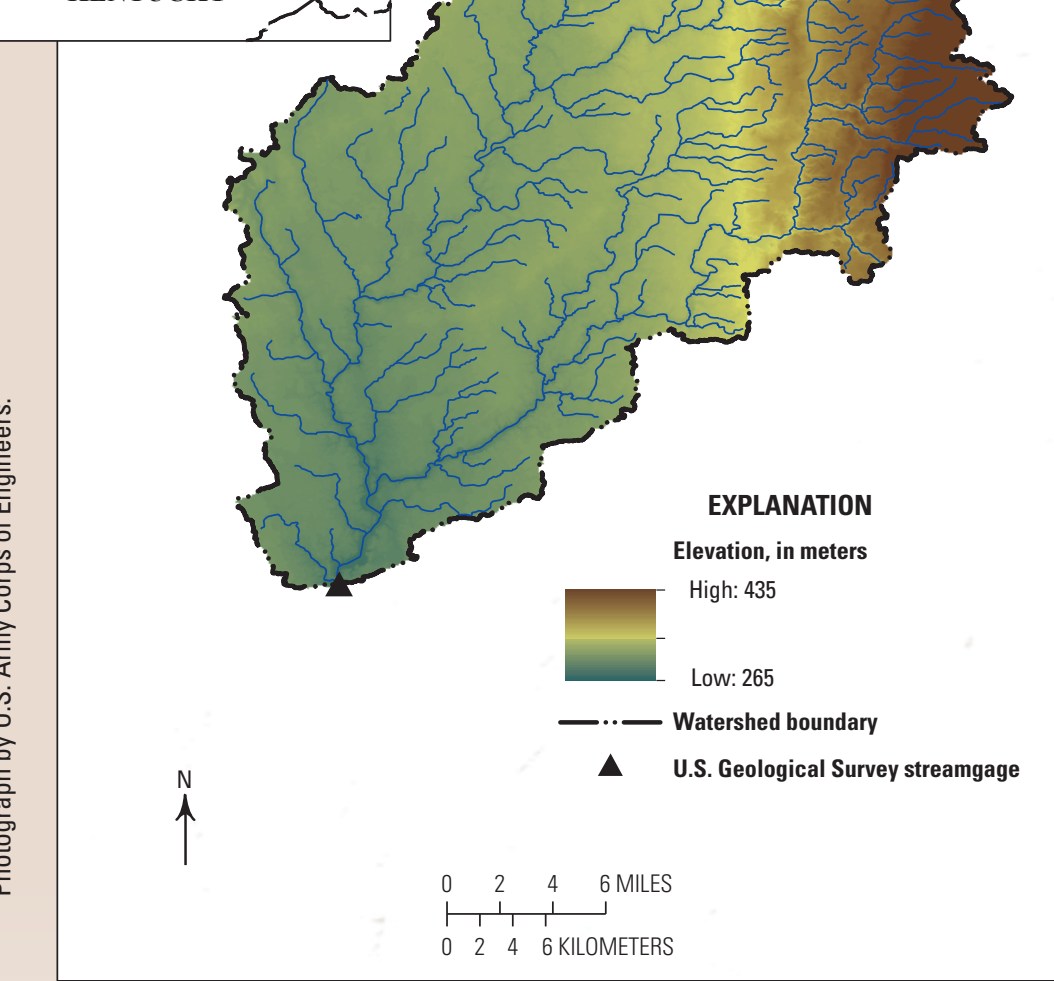

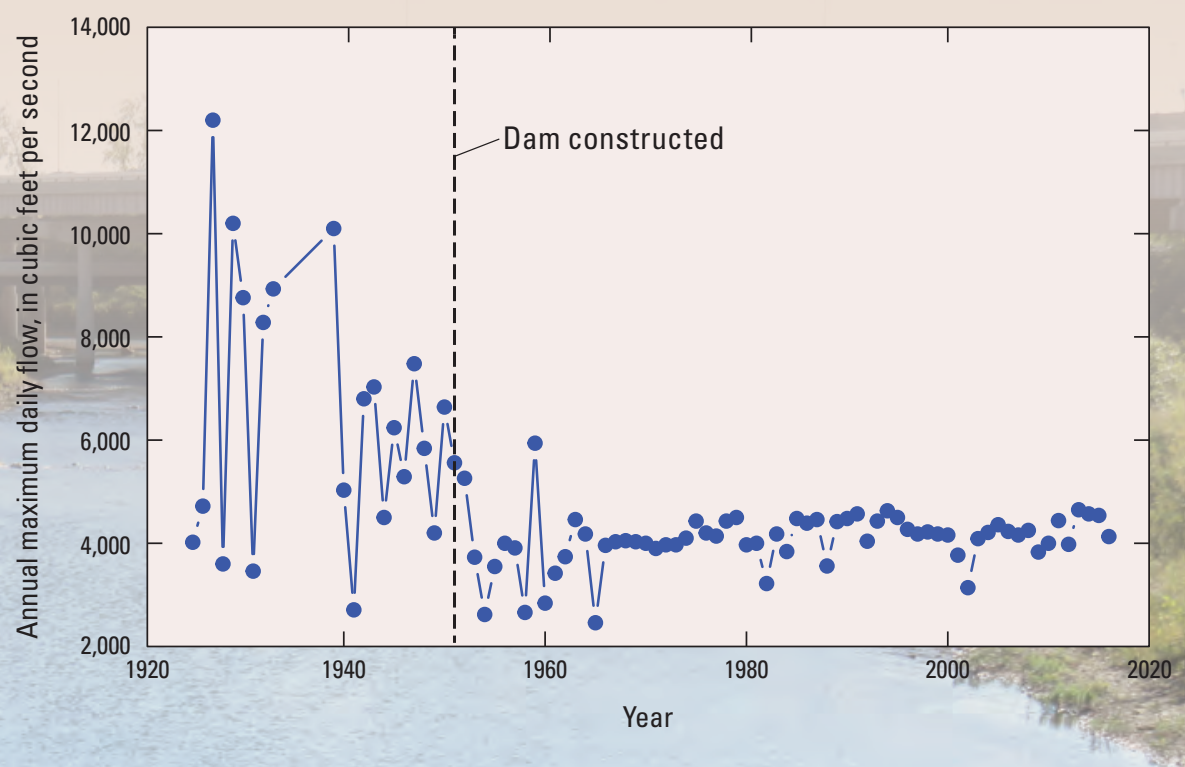

View of the Olentangy River near Columbus, Ohio. Photograph from Wikimedia Commons, Creative Commons Attribution-Share Alike 4.0 International license. 


\section{Reservoir Management Increases the Annual Variation of Low Flows}

Henrys Lake, Idaho, is a natural lake enlarged by the placement of a dam on the outlet stream, the Henrys Fork River, in 1923. The dam greatly enlarged the volume of Henrys Lake and was used to regulate flow for downstream irrigation. Reservoir management has focused on maintaining full storage capacity, which has caused significant streamflow modification downstream in the Henrys Fork River. Among other forms of flow modification, there is a large annual fluctuation in low flow - which typically occurs during winter. This happens because in drier years, flows during winter are used to fill the reservoir - which severely depletes low-flow magnitude in the river downstream. In wetter years, winter low flows are augmented with stored water from the reservoir, which results in unnaturally high flow. The net result is an extreme annual variation in low-flow magnitude -including many years when low flows are near zero. Growing concern about the population of native Oncorhynchus clarkii (cutthroat trout) in the river-which is a highly valued recreational fishery - and anticipated drought have fostered a highly collaborative approach to managing flows in the river basin, with the goal of restoring more natural streamflows beneficial to native trout (Henry's Fork Foundation, 2014).
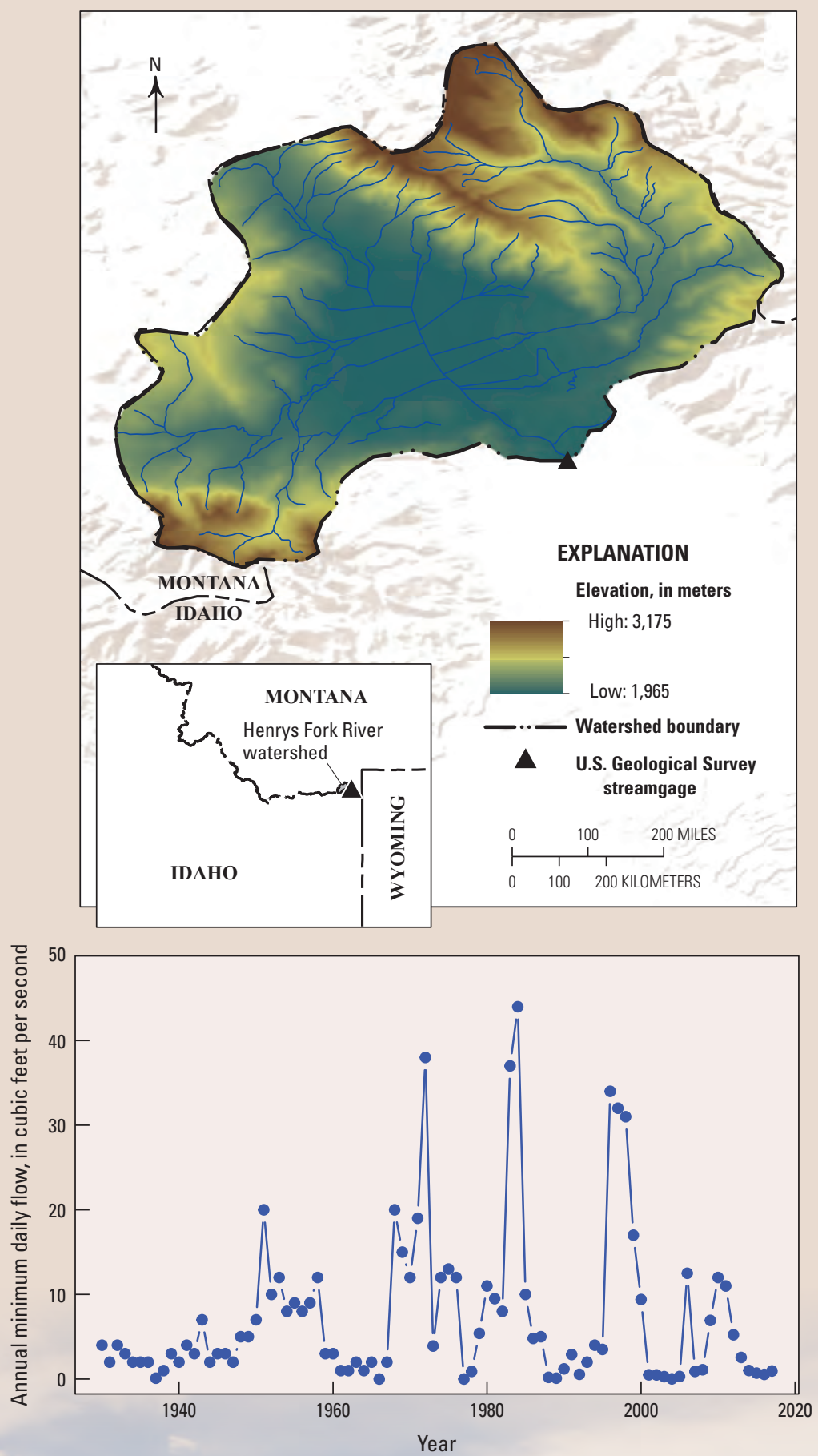

View of Henrys Lake, Idaho. Photograph by James Perdue. Used with permission. 


\section{Increased daily}

flow fluctuation

was common

in all types of

land- and water-

management

settings.

\section{Daily Flow Fluctuation}

Under natural conditions, daily fluctuations in streamflow are caused by precipitation events or the melting of accumulated snow, but a variety of human activities can also increase daily fluctuation (fig. C5). For example, reservoirs that release water downstream to generate hydropower often do so on daily and hourly schedules that correspond to peak power demands. Streams affected by irrigation diversions and return flows often experience wide daily fluctuations depending on local demands for water. Daily flow fluctuation tends to increase in urban streams because flows in these systems tend to be "flashy," meaning daily flows experience frequent rapid rises and declines because of runoff over impervious surfaces and the lack of natural wetlands and vegetation to slow runoff into the stream.

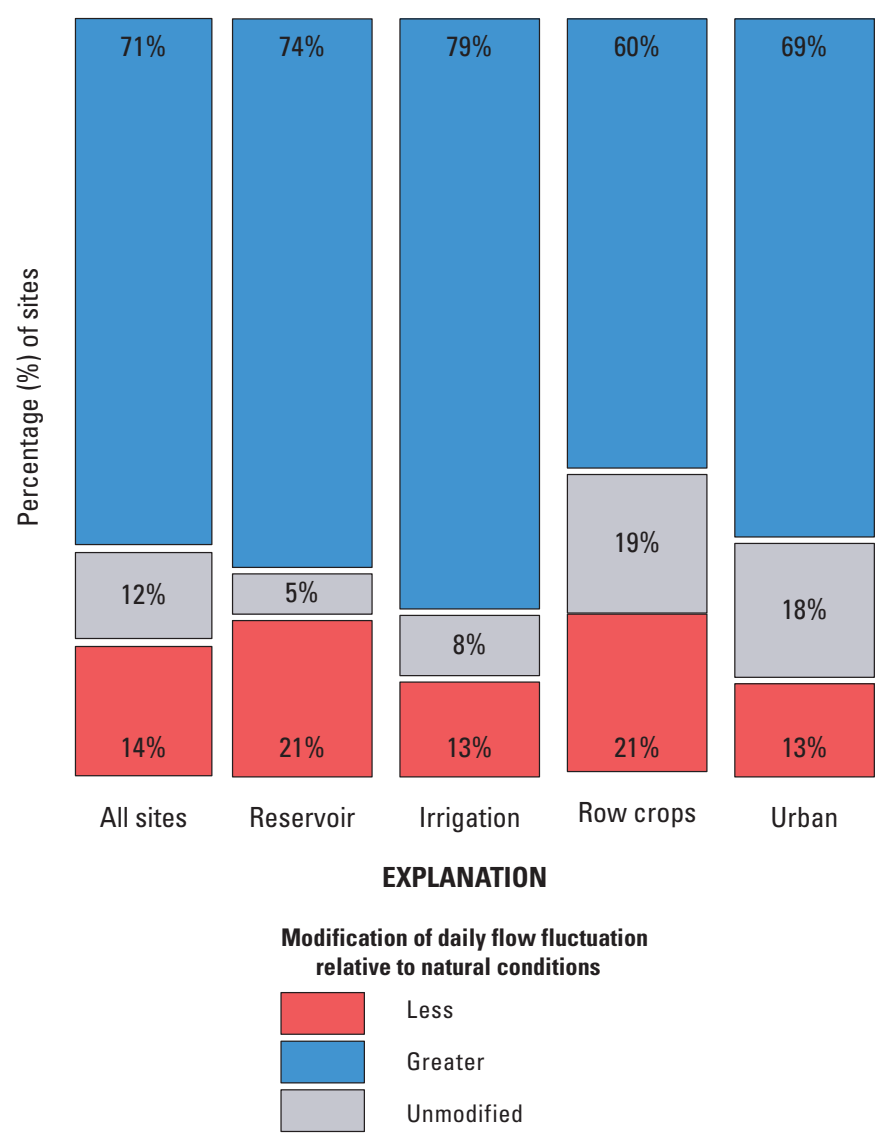

Figure C5. How daily flow fluctuation was modified in relation to land and water management. Each assessed streamgaging site is categorized based on the type of land and water management predominant in its watershed. Modification of daily flow fluctuation is categorized as less, greater, or unmodified relative to natural conditions. Percentages of assessed streamgaging sites in each category are given. For comparison, streamflow modification at all assessed streamgaging sites, nationwide, also is shown. 


\section{Land- and Water-Management Practices Increase Daily Flow Fluctuation of Streamflow}

The Bear River originates in the Uinta Mountains of northeastern Utah, flows north into Wyoming and Idaho, then returns to Utah where it empties into the Great Salt Lake. It is the largest river in the western hemisphere that does not empty into an ocean (Bear River Water Quality Committee of the Bear River Commission, 2017). Along its route, the Bear River provides water for municipalities, agriculture, industry, hydropower, recreation, and wildlife
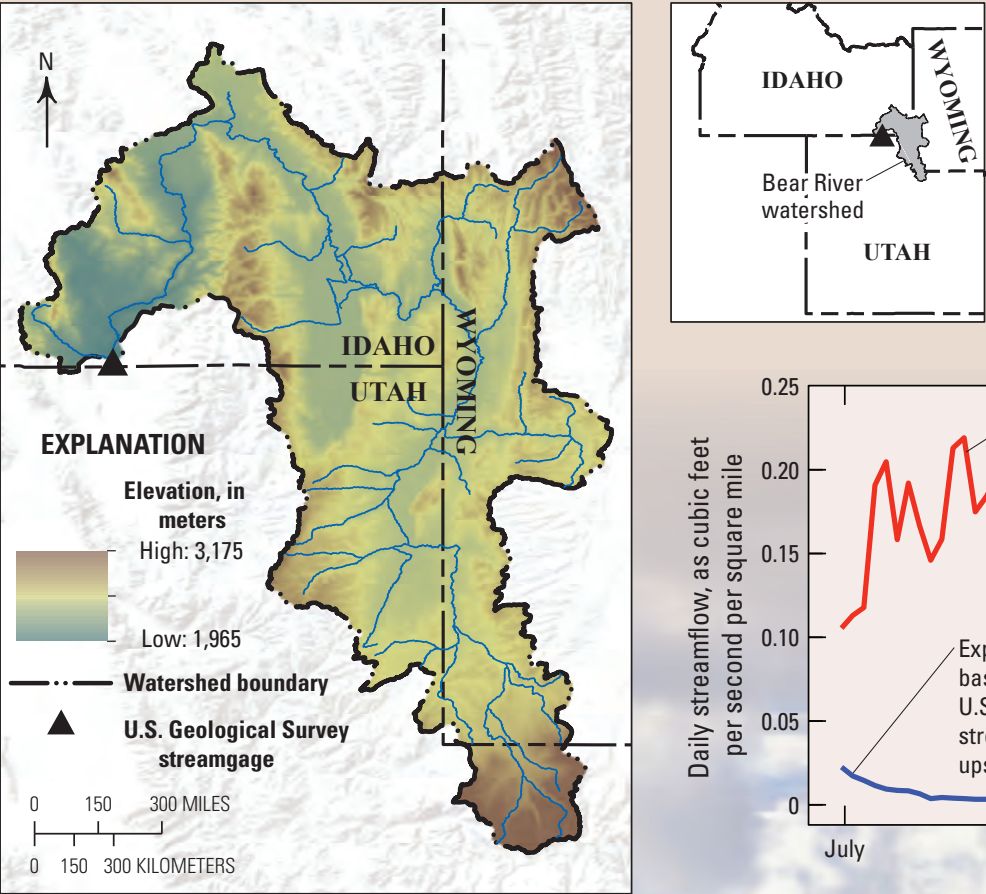

Streamflow in the lower sections of the river is heavily influenced by storage reservoirs, hydropower generation, diversions, and irrigation return flows. As a consequence, daily streamflow fluctuates more than would naturally be expected (see graph). Many parts of the watershed also suffer from poor water quality (Bear River Water Quality Committee of the Bear River Commission, 2017).

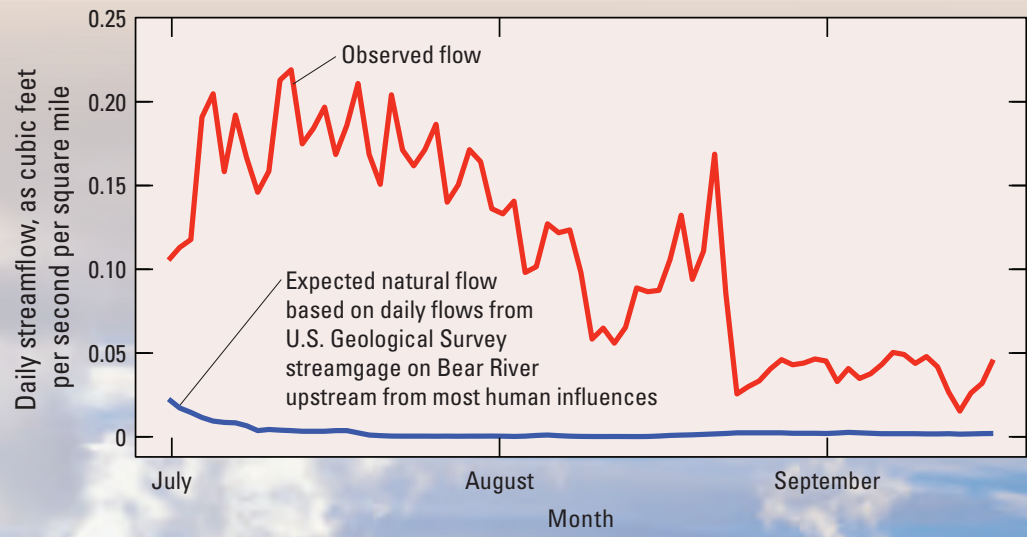

View of the Bear River, Utah. Photograph by Scott T. Smith. Used with permission. 


\section{Land and Water Management Modify the Timing of Low and High Flows}

The timing of low flows (left map) has been modified at 20 percent of assessed sites nationally (colored dots on map). The most common modification is for low flows to shift from fall into other seasons, which was most common in the central plains and parts of the western mountains. A shift from winter into other seasons was the second most common modification and was most common in the western mountains.
The timing of high flows (right map) has been modified at 21 percent of assessed sites nationally. The most common modification is for high flows to shift from spring into other seasons, and this shift occurred throughout the United States. A shift from winter into other seasons was the second most common modification and was most common in the southeast plains and parts of the western mountains.
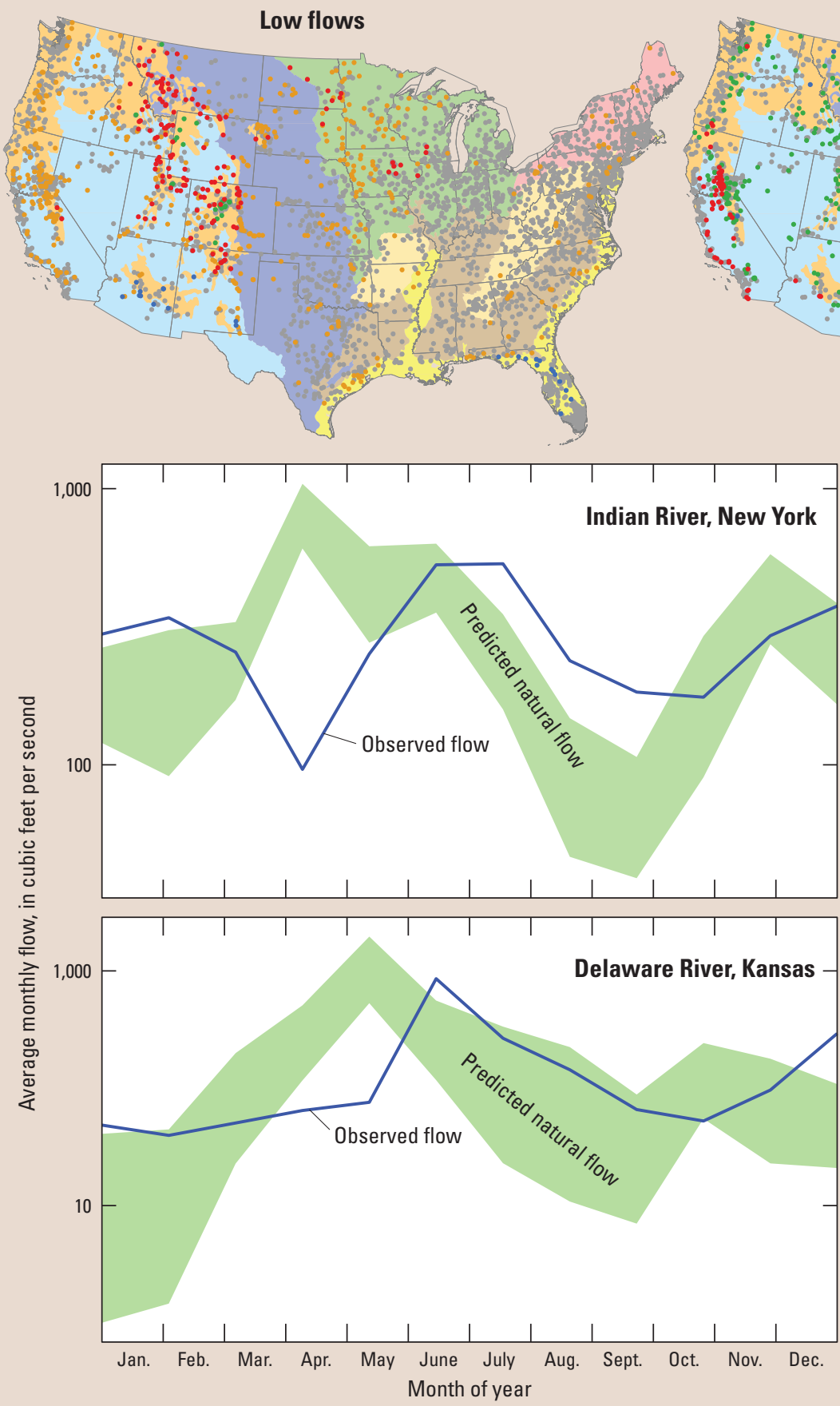

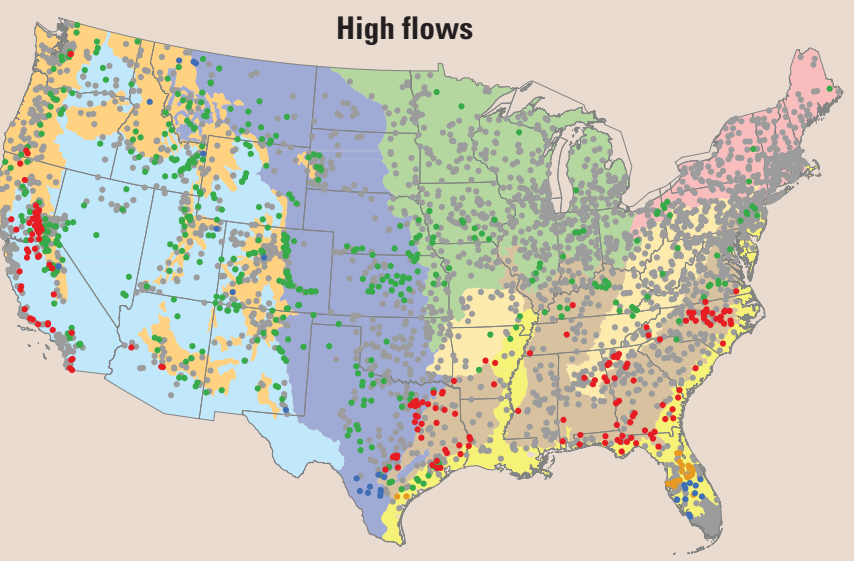

EXPLANATION

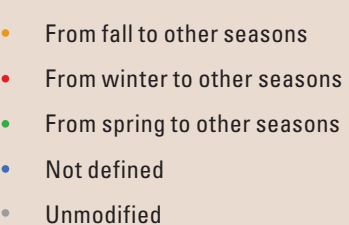

Two examples of modified flow timing are shown to the left. Under natural conditions (depicted with a green shaded band of uncertainty on graph), low flows in the Indian River should occur in autumn. However, in reality (depicted with a blue solid line on graph), low flows often occur in other seasons. The Indian River is influenced by a dam and storage reservoir immediately upstream.

The Delaware River, Kansas, also is located downstream from a storage reservoir. Under natural conditions, high flows occur during the spring, which is typically the season with the most rainfall. Because of dam operations, however, high flows in the Delaware River are common during other seasons, such as summer. 


\section{Chapter D. Streamflow Modification and Climate}

Climate variability and change are the topics of much scientific research and public discussion. The strong dependence of streamflow on climate raises two important questions regarding the effects of climate on aquatic ecosystems: How have streamflow characteristics critical to ecological health been affected by recent (since 1955) changes in climate? And how do the effects of climate-related changes compare with changes in streamflow caused by land and water management?

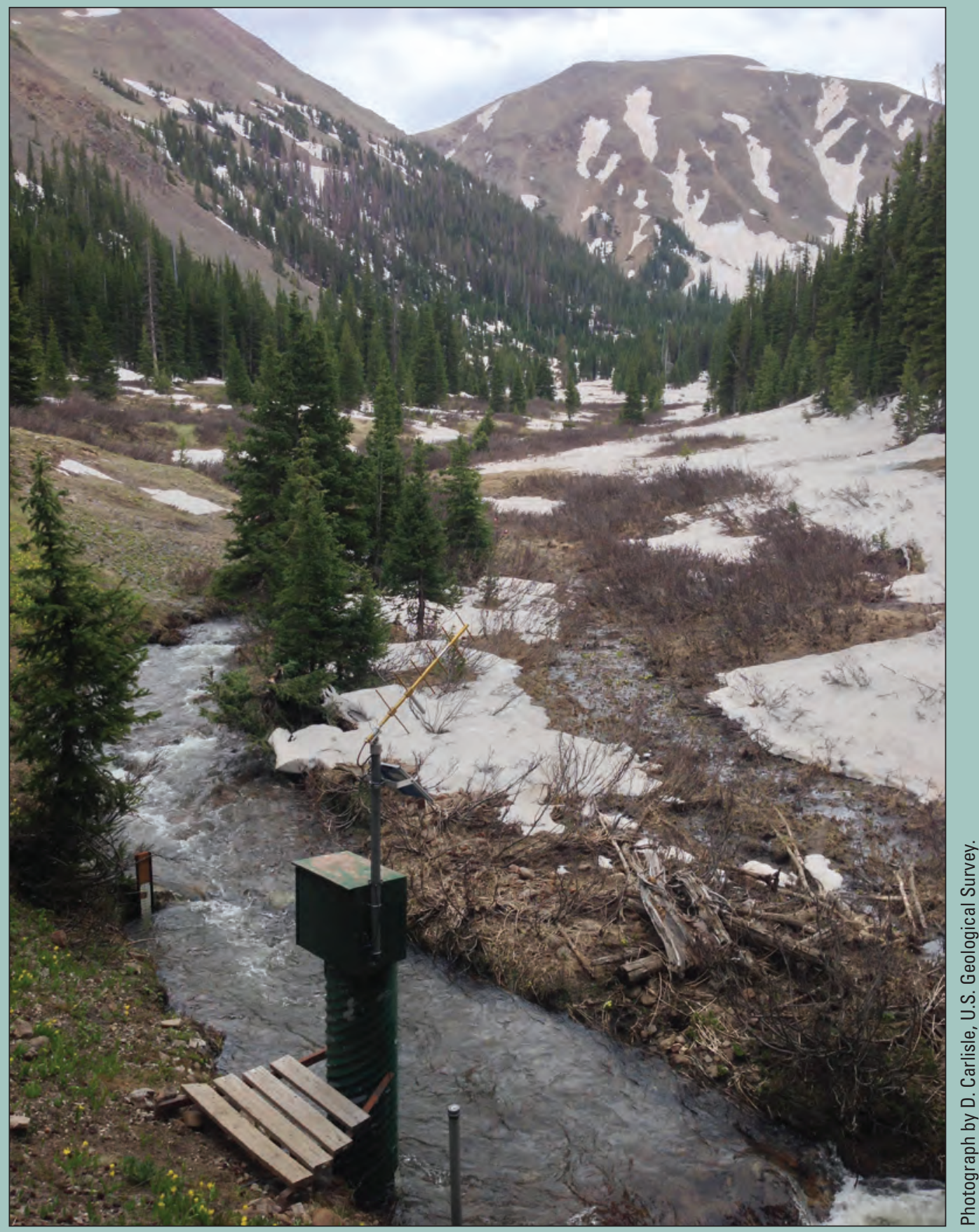

Natural patterns of streamflow in the Michigan River, Colorado, are highly dependent on the amount of snow accumulation during winter and the timing and rate of snowmelt, which in turn are affected by seasonal patterns of precipitation and air temperature. 
In this chapter, climate-induced changes to streamflow since 1955 are described (fig. D1). In addition, the relative effect of climatic variation versus land and water management on streamflow characteristics is compared. The natural seasonal patterns in streamflow respond to the seasonal and annual cycles of precipitation and air temperature. The timing of precipitation and whether it falls as rain or snow have profound effects on the natural patterns in flow that ecosystems depend on. Most stream-dwelling organisms evolved survival strategies that depend on patterns in streamflow and water temperature that existed for millennia. Recent and rapid climate-induced changes to natural patterns of streamflow and water temperature, however, could threaten the survival of many species and the health of freshwater ecosystems (Grimm and others, 2013). In addition to the effect of recent climatic changes, natural streamflow patterns have been profoundly modified by land use and water management (Poff and others, 2007; Eng and others, 2019), which has led to declines in ecological health in many streams and rivers (Webb and others, 2013).

Two questions about climate-related changes to streamflow are examined here. First, how have climatic factors - in the absence of land and water management - affected streamflows in recent decades? To answer this question, long-term trends in streamflow since 1955 were examined for 599 river basins where the effects of land use and water management are minimal (considered hydrologic "reference sites") and have not changed in the last 60 years. Any measured changes in streamflow in these basins are therefore most likely a result of changes in precipitation, air temperature, and other climatic factors. Second, how does streamflow modification caused by climatic factors compare to streamflow modification caused by land and water management? To answer this question, climatic variation and land and water management were examined over the same period — 1980 to 2014 — at the 3,355 streamgaging sites assessed in this report (see chapter B). For each basin, two estimates of streamflow modification were
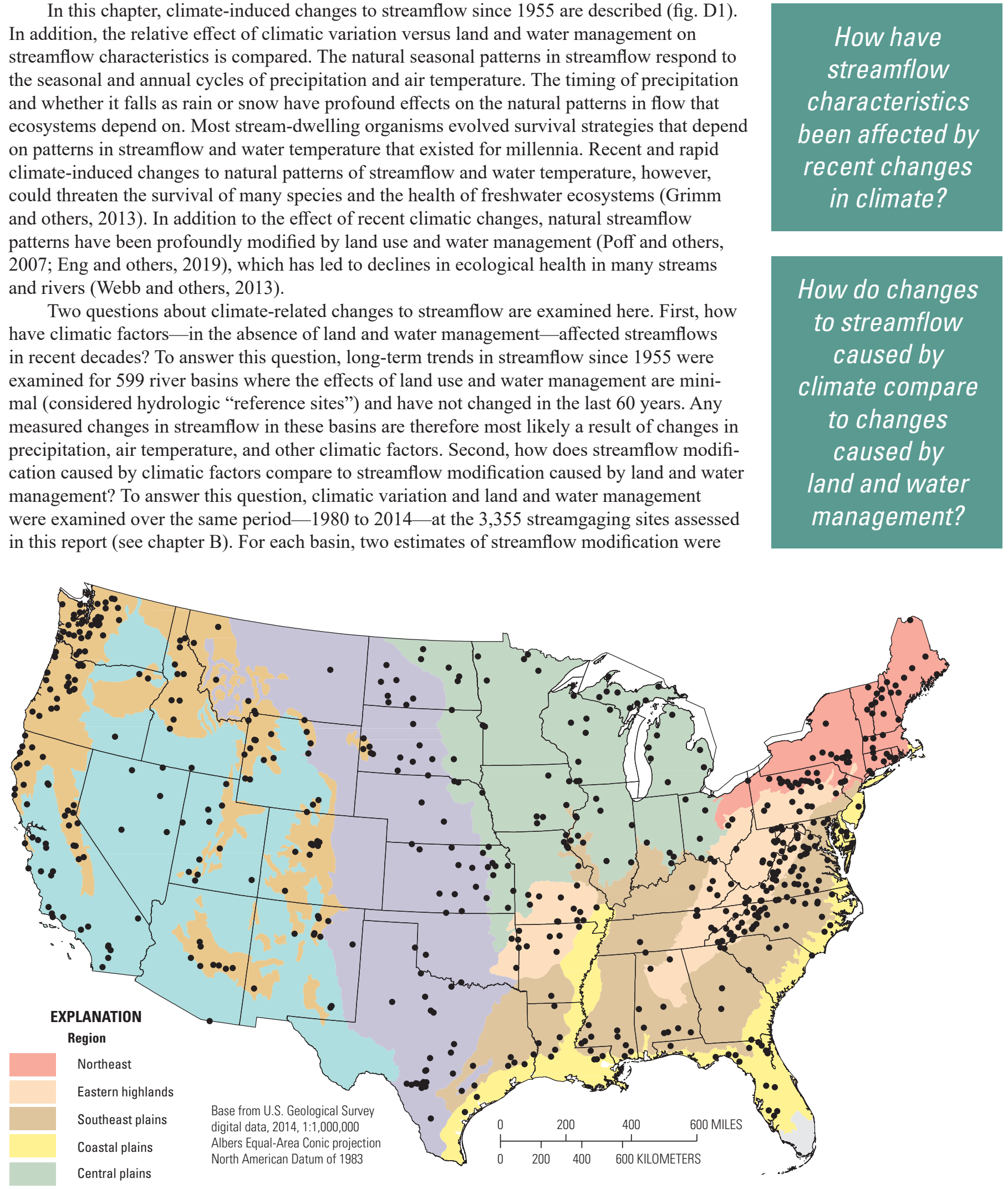

Western plains

Western deserts

Western mountains

Figure D1. Map showing where climate-induced changes in streamflow characteristics were evaluated. The 599 streamgaging sites are considered hydroclimatic reference sites because changes in land and water management since 1955 have been minimal. Any changes in streamflow characteristics in these basins are therefore most likely caused by changes in climate. 


\section{Recent Changes in Streamflow in a Historical Context}

Under natural conditions, year-to-year fluctuations in streamflow are strongly related to year-to-year fluctuations in precipitation, as shown in this graph of annual streamflow and precipitation at Bunnel Brook, Connecticut, from 1950 to 2011. Because of this strong relationship, long-term patterns in precipitation are good indicators of long-term patterns in streamflow. This is especially useful where long-term streamflow data from monitoring sites are limited.

Over the last 100 years, precipitation — and likely streamflow-has fluctuated greatly from one year to the next and from one region to another. Two patterns are evident in all regions, however. First, precipitation increased in all regions beginning in the 1970s, which suggests that streamflows too have increased in recent decades. Second, each region has experienced cycles of wet and dry periods, usually lasting several years. Several periods of time when

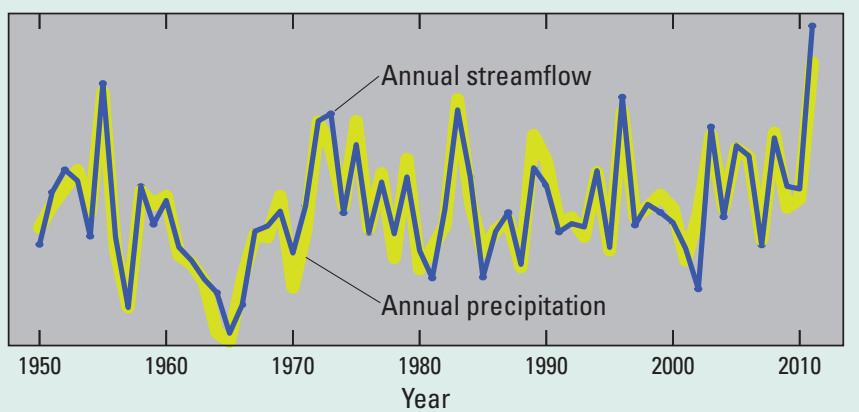

climatic conditions had historic implications are apparent: the 1930s Dust Bowl in the plains regions, the severe drought in the northeast during the 1960s, and the recent prolonged wet period in the northeast. These long-term patterns in precipitation and streamflow are critical to understand the context of trends in streamflow caused by recent trends in climate.

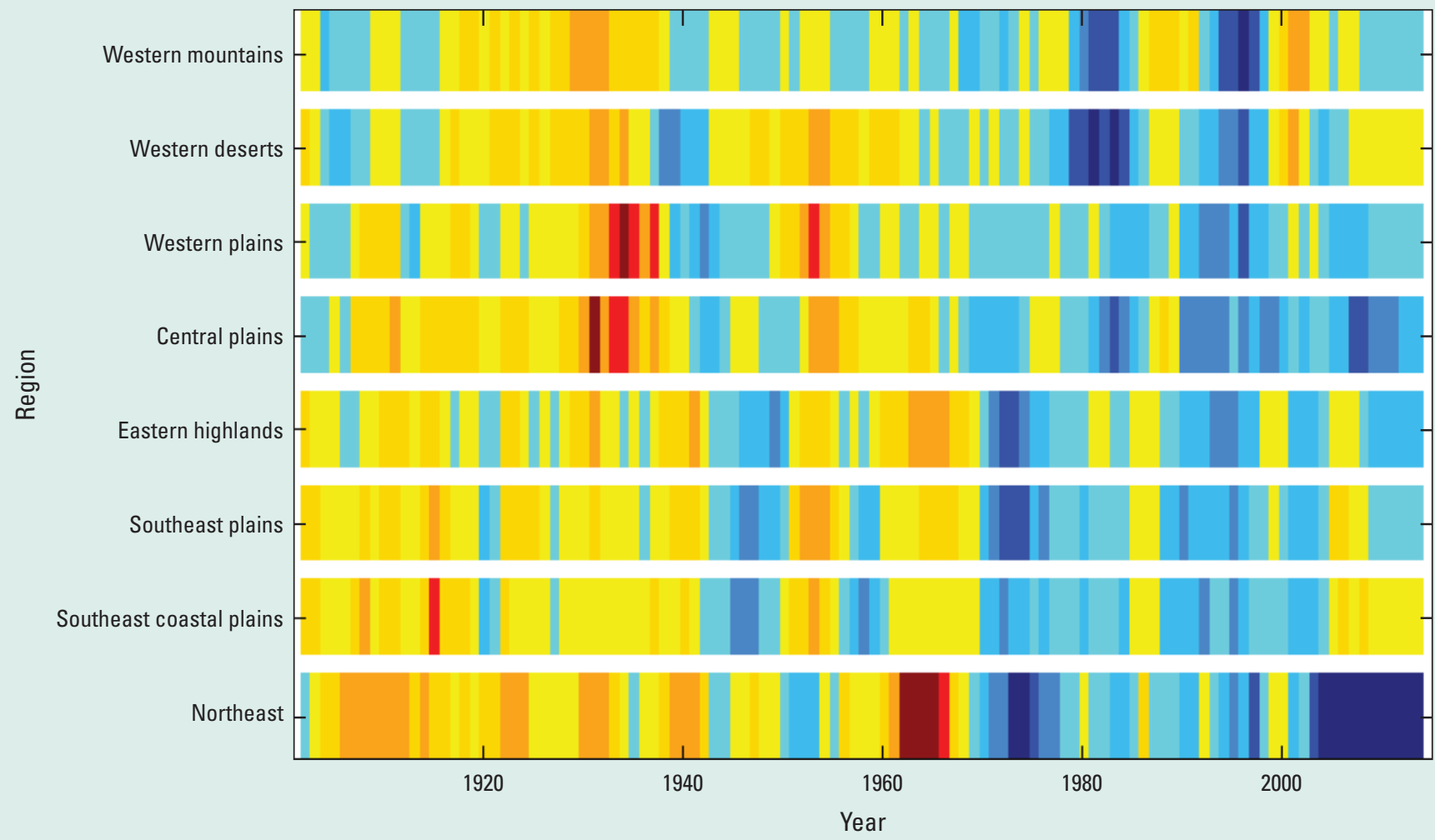

EXPLANATION

Wetter than average

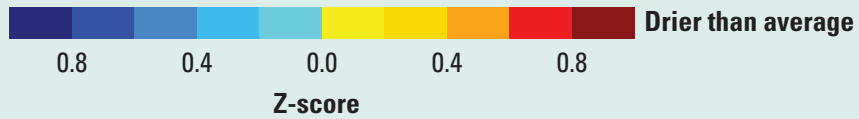

This graph shows year-to-year fluctuations in precipitation over the 20th century for the major regions of the conterminous United States. Each horizontal band shows the year-to-year fluctuations in precipitation, with blue shades indicating above-average and $\mathrm{red} / \mathrm{yellow}$ shades indicating below-average precipitation each year. The general pattern of wetter years since 1970 is evident in most regions. 
computed. One estimate was made while mathematically holding climatic factors constant (as explained in the "How Was Streamflow Characterized and Assessed" box in chapter B), which reveals the effect of land and water management on streamflow modification. The second estimate was made while mathematically holding land and water management constant, which reveals the effect of climate on streamflow modification. In this chapter, comparisons of these two estimates of streamflow modification are summarized across regions and nationally, which provides a broad perspective on the relative effect of climate versus land and water management on streamflow modification. Importantly, streamflow changes because of climatic factors or land and water management are more fully understood when considered in the context of streamflow and climatic changes over the last century (see the "Recent Changes in Streamflow in a Historical Context" box on page 41).

\section{Climate-Related Trends at Reference Sites, 1955-2014}

The magnitude, frequency, and duration of streamflows have changed substantially over the last 60 years in relation to changes in climate. Streams in most regions had climate-related changes in flow that correspond to longterm patterns in precipitation (fig. D2). Precipitation in the northeast and central plains has been higher than average since the 1970s (see the "Recent Changes in Streamflow in a Historical Context" box), which has caused low flows to be higher in magnitude but lower in frequency and duration. Also, high flows in these two regions have generally become higher in magnitude, more frequent, and of shorter duration (in the northeast only). In contrast to the northeast and central plains, the southeast plains and coastal plains have become slightly drier since 1970 . In these two regions, low flows have become lower in magnitude and have a longer duration, whereas high flows have not changed appreciably.

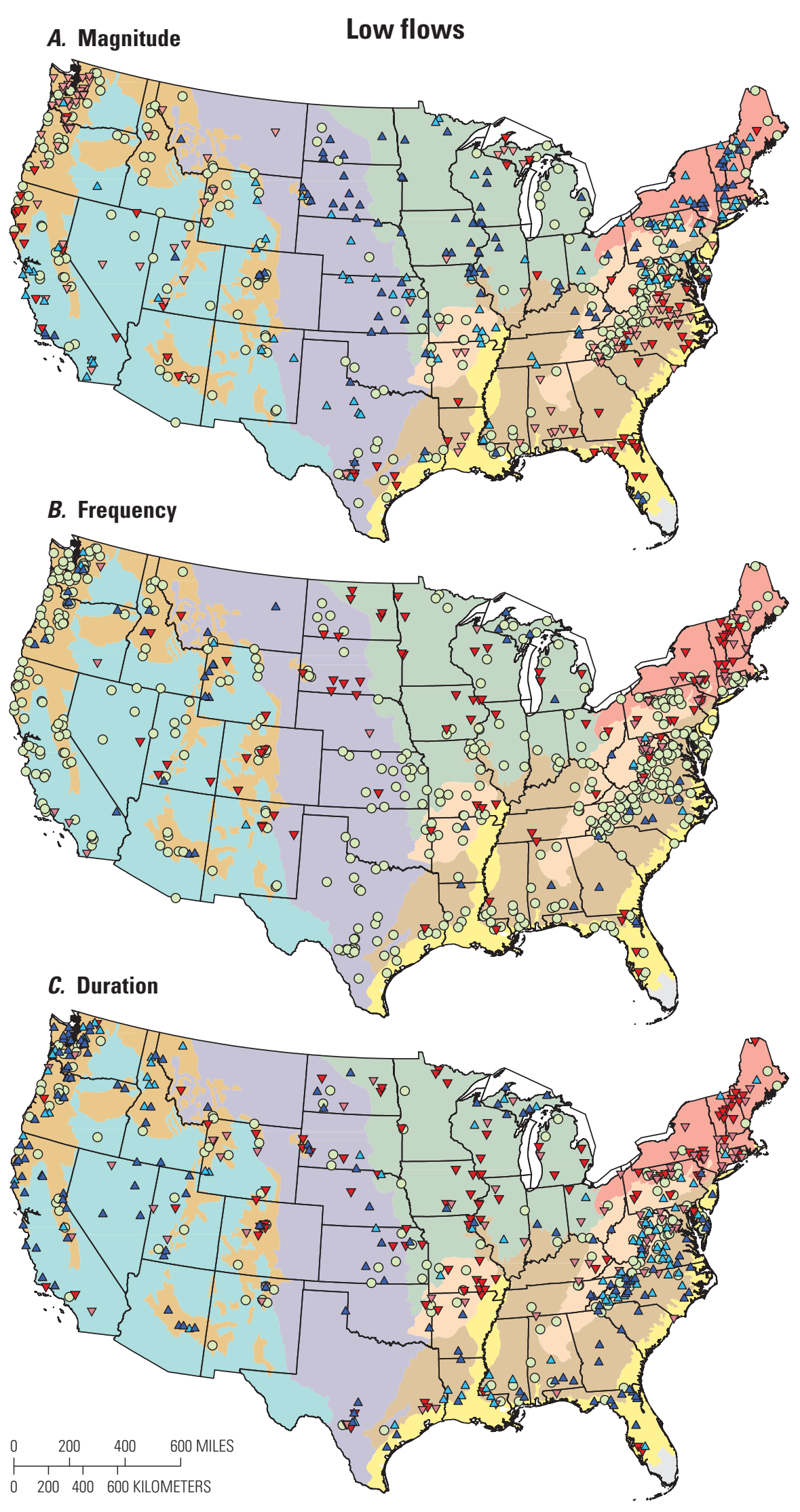

Figure D2. Regional patterns in the climate-induced trends in streamflow characteristics from 1955 to 2014. 


\section{Magnitude}
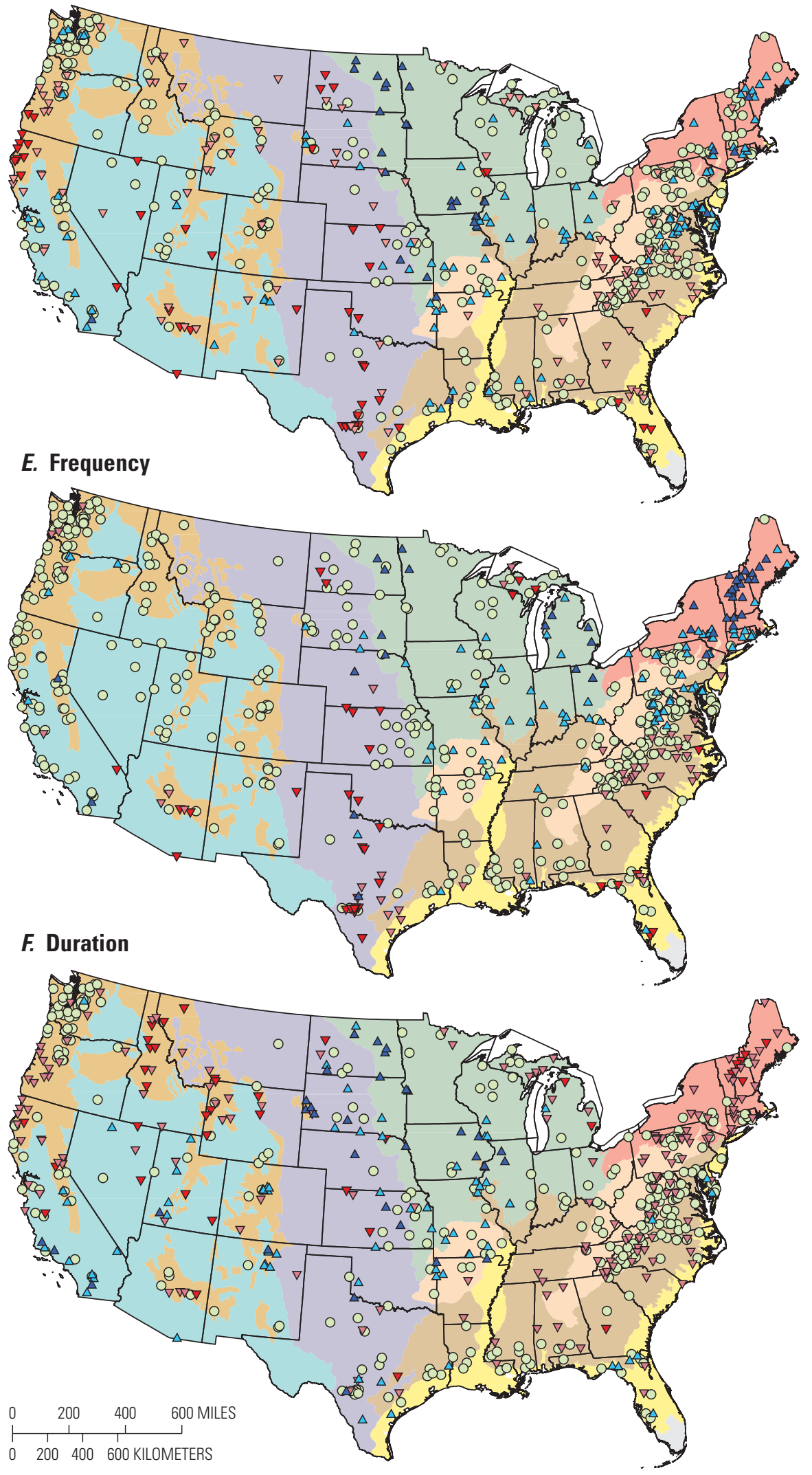

Figure D2. Regional patterns in the climate-induced trends in streamflow characteristics from 1955 to 2014.-Continued

\section{EXPLANATION}

\begin{tabular}{|c|c|}
\hline \multicolumn{2}{|c|}{ Region } \\
\hline & Northeast \\
\hline & Eastern highlands \\
\hline & Southeast plains \\
\hline & Coastal plains \\
\hline & Central plains \\
\hline & Western plains \\
\hline & Western deserts \\
\hline & Western mountains \\
\hline & Trend \\
\hline$\Delta$ & Greater than 50-percent increase \\
\hline$\Delta$ & 20 - to 50 -percent increase \\
\hline o & Less than 20-percent change \\
\hline$\nabla$ & 20- to 50-percent decrease \\
\hline$\nabla$ & Greater than 50-percent decrease \\
\hline o & Not estimated \\
\hline
\end{tabular}

Climate-related trends in streamflow throughout the west are more subtle than in other parts of the country and indicate that climate-related factors other than precipitation might be affecting streamflow. For example, several studies have documented that the timing of high flows in the western mountains has shifted to earlier in the year because increased air temperatures in the spring have initiated earlier snowmelt in recent decades (Stewart and others, 2004; McCabe and Clark, 2005; Rood and others, 2008). In the western plains, low flows have not appreciably changed but high flows have become lower in magnitude. In the western mountains and deserts, low flows have become longer in duration, but high flows have not changed substantially.

\section{Over the last 60 years, the magnitude, \\ frequency, and duration of streamflows in most regions have changed because of climate.}




\section{The Timing of High Flows is Changing Due to Climate}

The timing of high flows is of critical importance to stream ecosystems, especially to species whose reproductive periods evolved in synchrony with high-flow events. The timing of high flows is changing because of climate, based on observations from 1955 to 2014 at nearly 600 streamgages that are primarily affected by climate rather than by land or water use. In all eastern regions except the coastal plains, high flows are shifting from spring to other months. Changes in the west are more complex but indicate high flows are becoming more predominant in spring as opposed to summer and winter. Also of importance is that nationally, climate-caused changes in the timing of low flows were minimal (results not shown).

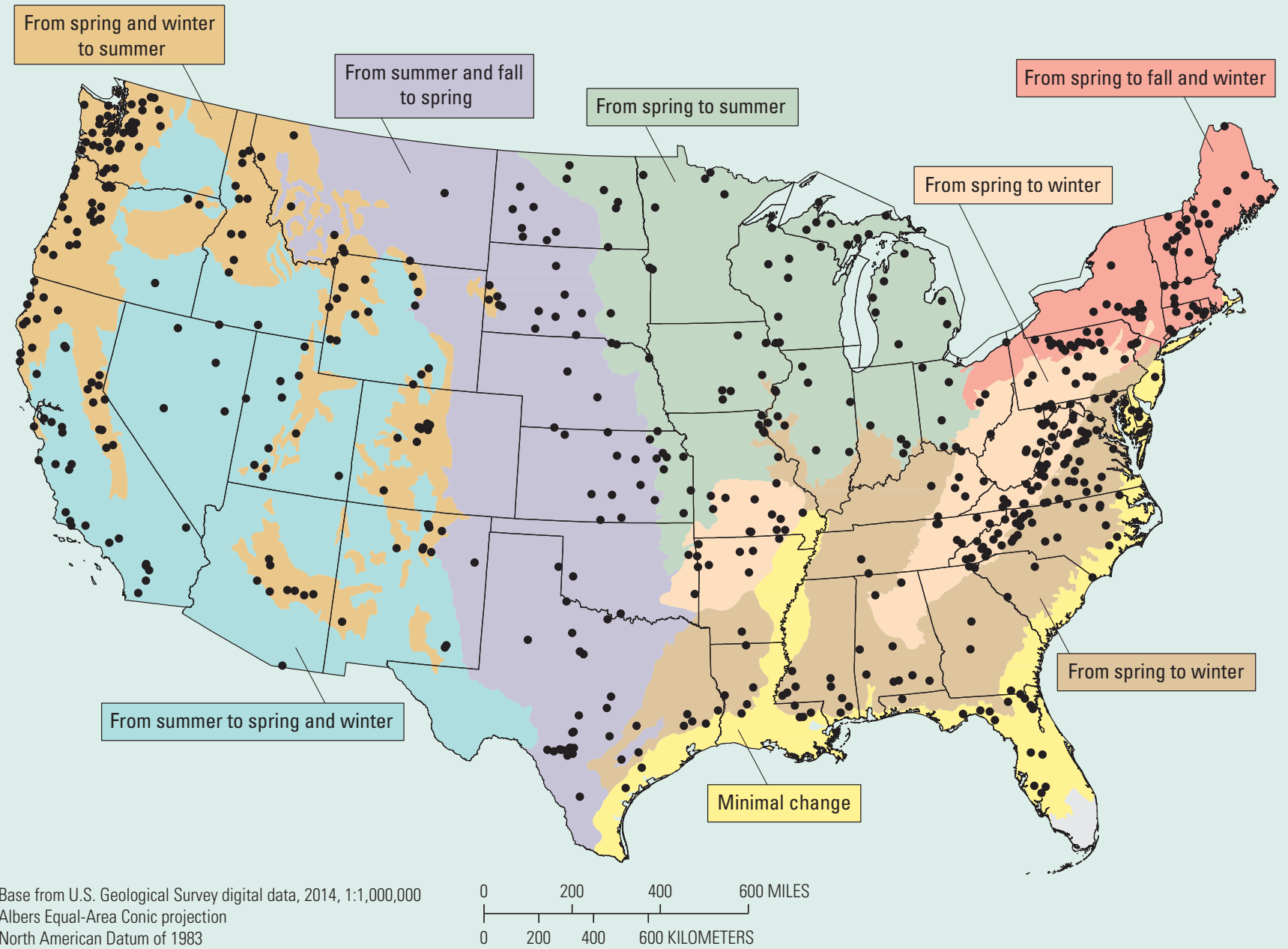

\section{EXPLANATION}

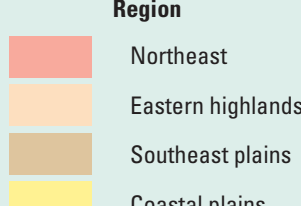

Central plains

Western plains

Western deserts

Coastal plains

Western mountains 


\section{Year-to-Year Fluctuations in Streamflow Make it Difficult to Discern Underlying Long-Term Trends}

The duration of low flows in Neversink River, New York, has fluctuated substantially since 1950 . This fluctuation is almost entirely caused by year-to-year variation in precipitation, which is partly related to global-scale climate processes such as El Niño and the North Atlantic Oscillation. Underlying the year-to-year fluctuation is a long-term
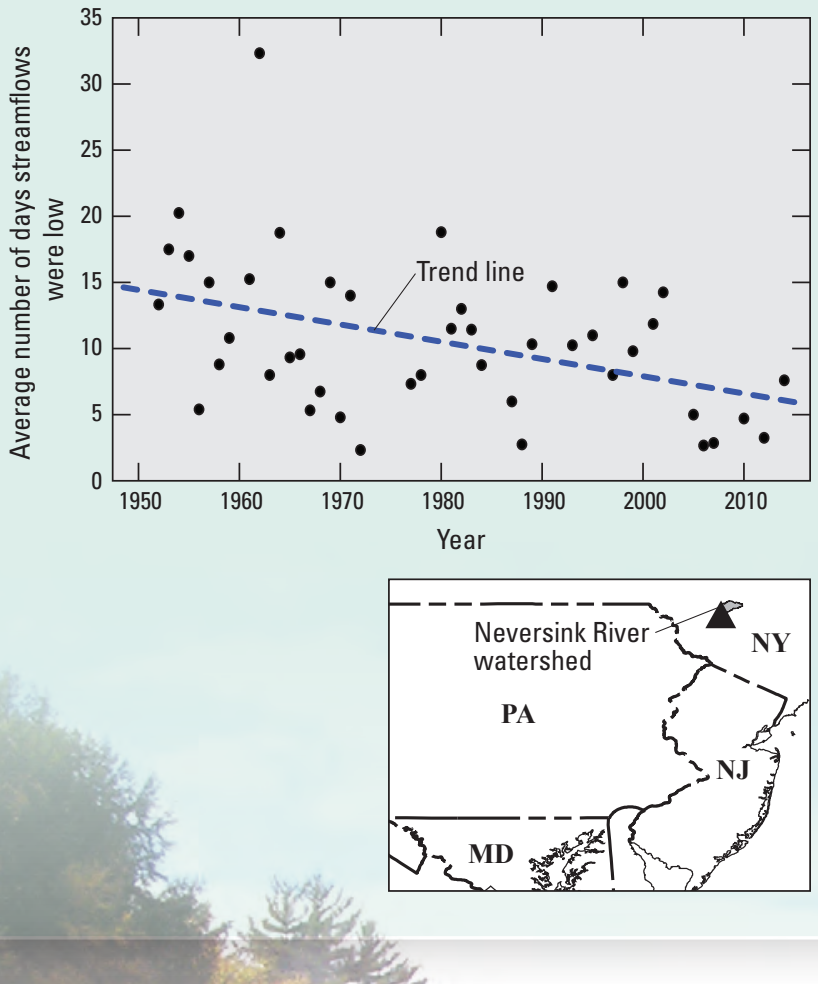

View of the Neversink River, New York

Photograph by Jason Neuswanger.

Used with permission.

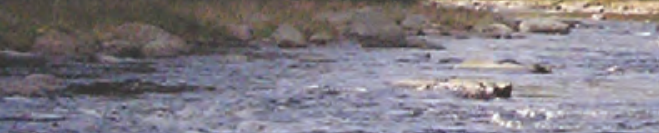

downward trend. The trend is likely caused by climatic changes because the watershed of Neversink River is largely undeveloped. Because this long-term trend is relatively small compared to the large year-to-year fluctuations, data that span many decades are required to reliably detect climate-caused trends in streamflow.

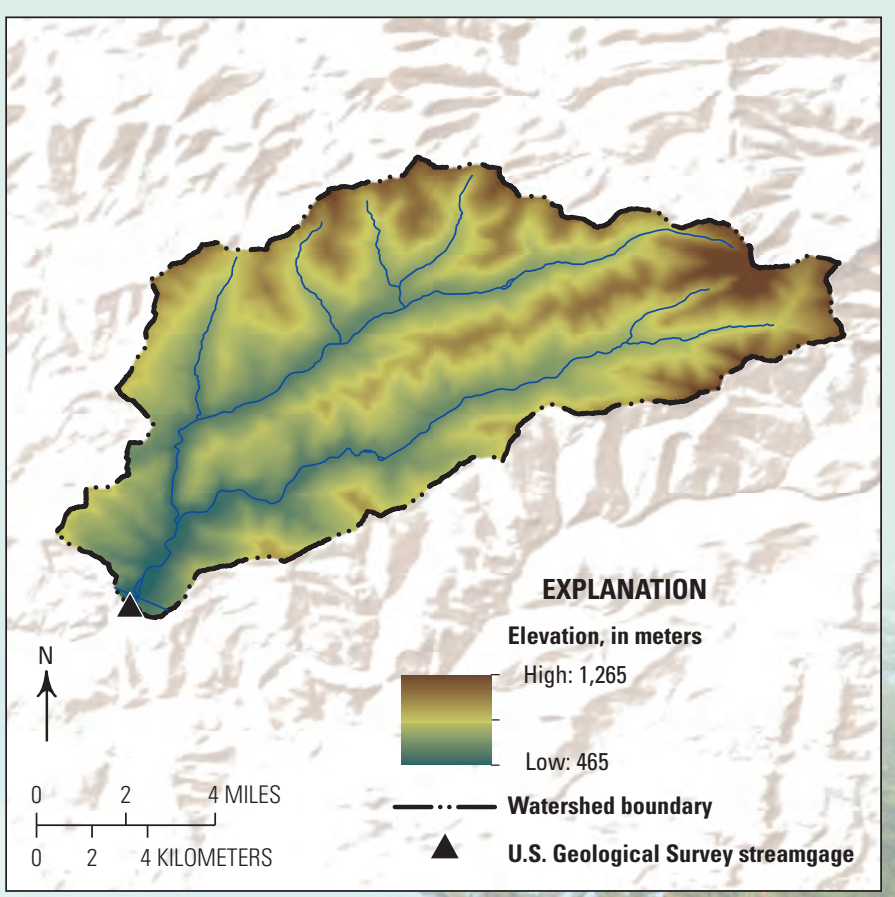

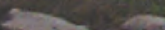




\section{High Flows in Spring are Becoming More Rare in Towanda Creek, Pennsylvania}

Like streams in many regions, most high flows in Towanda Creek, Pennsylvania, naturally occur in the spring. Many stream-dwelling organisms therefore have adapted to this pattern, and some likely require it to complete their life cycles. Around 1950, most of the high-flow events in Towanda Creek occurred in the spring, but by 2010 less than half did. This trend indicates that high-flow events in seasons other than spring are becoming more common, which may disrupt the life cycles of some species.
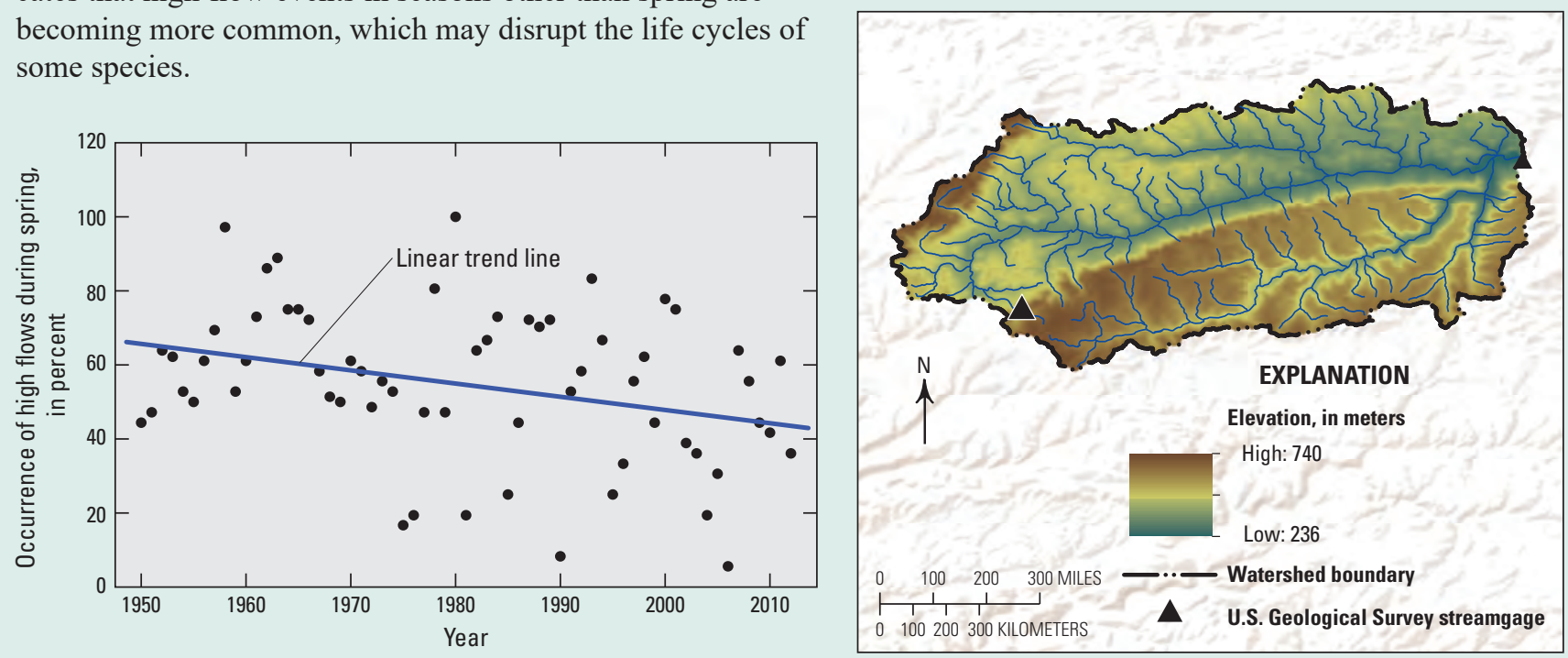

\section{Climate Compared to Land and Water Management, 1980-2014}

In general, recent variation in climate (1980-2014) has had a relatively minor effect on streamflow compared to the effects of land and water management (fig. D3), but the effects of the two are known to interact (Palmer and others, 2009). For example, if the storage of water in winter snowpack becomes less reliable in the future, reservoir operations will likely be modified to capture water during other seasons, which would then change the ways that a dam modifies streamflows. Such interactive effects between climate and management were not examined in this report. It also is important to note that the period for which climate variability was examined in this report was selected to match the period for which information on land- and water-management data were available; however, climate-mediated changes to flow would have been comparatively larger had a longer period been assessed (see findings in previous section).

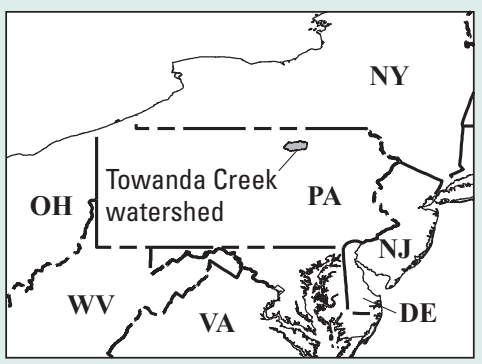




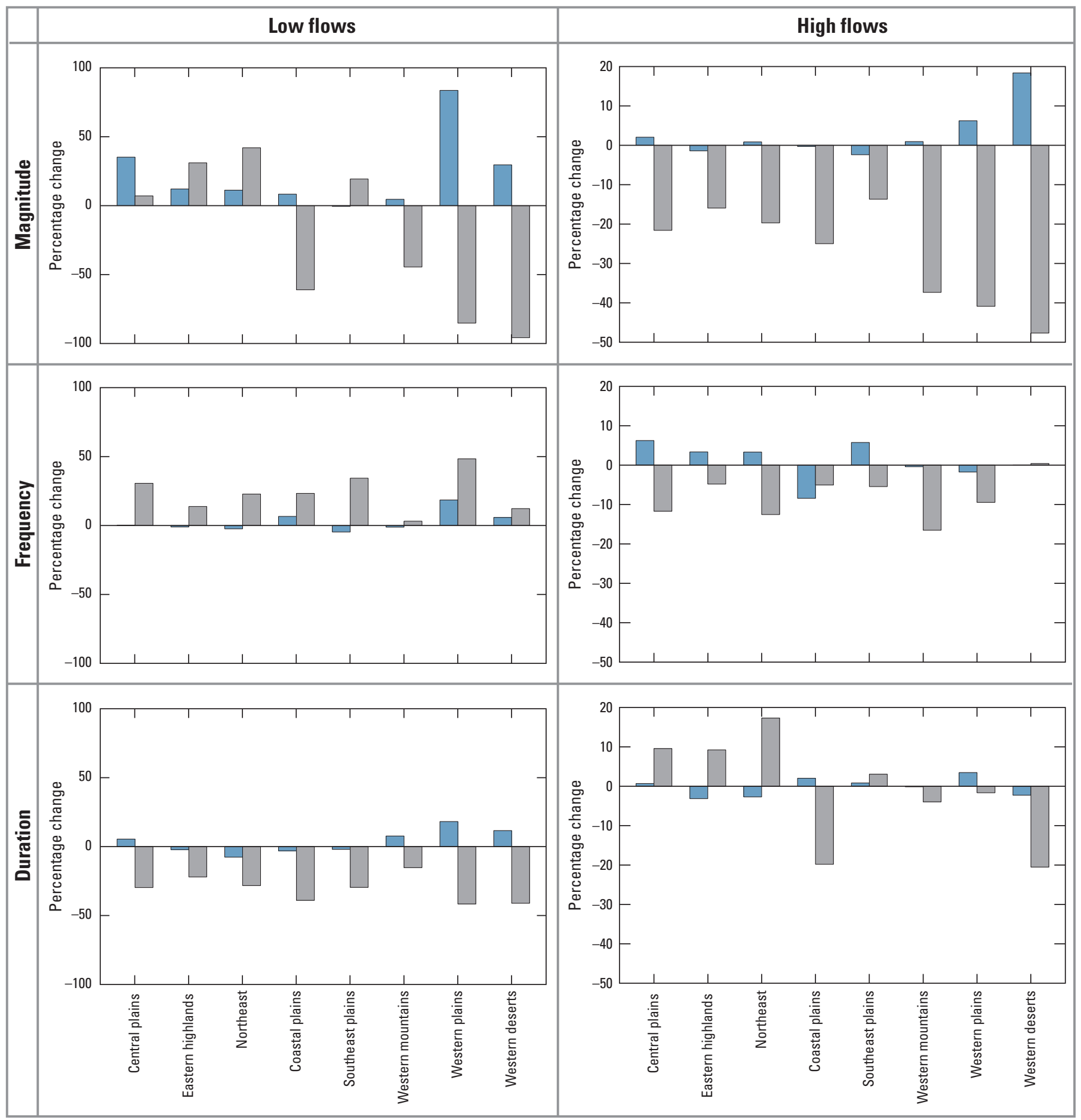

Figure D3. The relative effects of climate versus land and water management on streamflow modification from 1980 to 2014 . In most regions, changes to flow caused by climate (blue bars) were small compared to changes caused by land and water management (gray bars) over the same period. The length of each bar indicates the median change among all assessed streamgaging sites within each region. 


\section{Magnitude, Frequency, and Duration of Low Flows}

In most regions, recent changes in climate (1980-2014 average compared to the 19502014 average) have had a relatively minor effect on low flows compared to the effects of land and water management. There were, however, strong regional differences in the relative effect of climate compared to land and water management on some characteristics of low flow because of regional differences in land use and climatic variability.

In most regions, low-flow magnitude was changed more by land and water management than by climate. In irrigated regions (coastal plains, western plains, western deserts, and western mountains), land and water management tended to decrease low-flow magnitude, whereas climate tended to increase low-flow magnitude, a finding consistent with previous research (Poshtiri and Pal, 2016). This opposing pattern suggests that, in some river basins, a tendency toward a wetter climate (1980-2014 average compared to long-term average) may counteract the effects of low-flow depletion caused by land- and water-management practices. However, this pattern also suggests that drought conditions likely would intensify the depleting effects of land and water management on low streamflows. In contrast to all other regions, climate-related effects on low-flow magnitude were as large as or larger than the effects of land and water management in the central and western plains. The tendency for land and water management to increase low-flow frequency was much greater than the effects of climate across all regions. Similarly, the tendency for land and water management to decrease the duration of low flows was much greater than climate effects in all regions.

\section{Magnitude, Frequency, and Duration of High Flows}

In most regions, recent changes in climatic conditions (1980-2014 average compared to long-term average) have had a relatively minor effect on high flows compared to the effects of land and water management. There were, however, some regional differences in the relative effect of climate versus land and water management on some characteristics of high flow, most likely because of geographic differences in land use and climatic variability.

High-flow magnitude was affected more by land and water management than by climate in all regions. Land and water management consistently caused a decrease in high-flow magnitudes. In contrast, climate-related changes were relatively small in all regions except the western deserts and western plains, where climate changes tended to cause high-flow magnitude to increase, a distinct difference from the decrease in high-flow magnitudes caused by land and water management.

High-flow frequency was affected more by land and water management than by climate in all but two regions. Land and water management generally caused high-flow frequency to decrease, whereas climate caused increases and decreases. Further, the effect of climate on high-flow frequency was more evident than it was on high-flow magnitude or duration. In the southeast plains and the coastal plains, climate seemed to have a larger effect than land and water management. Streams in these regions did not have strong climate-related trends over the longer term (1955-2014); nevertheless, these changes were greater than changes due to land and water management.

High-flow duration also was changed more by land and water management than by climate, but the direction of effects varied regionally. In the coastal plains and western deserts, and to a lesser extent in the western mountains and western plains, high-flow duration tended to decrease because of land and water management. In the central plains, eastern highlands, and northeast, land and water management tended to cause high-flow duration to increase. The effects of climate on high-flow duration were small (less than a 5-percent change) and indicated increases and decreases among regions.
Land and water

management

caused greater

changes to high

flows than did

climate during

the 1980-2014

period. 


\section{Chapter E. Ecological Consequences of Streamflow Modification}

Streams and rivers are dynamic and verdant parts of our Nation's landscape. We depend on streamflow for drinking, agricultural production, and recreation. And for the diverse ecosystems that are supported by them, the flow of streams and rivers is life itself.

For aquatic life in streams, both the surge of high flows during a flood and tranquil low flows provide conditions that are critical to survival. The growth and survival of many species depend on periods of sustained low flow, but when low flows are too low, the streambed can dry out, which eliminates habitat for aquatic life. High flows, on the other hand, are essential because they flush accumulated sediment and import woody debris and cobble needed for many species, although extreme high flows can scour the streambed and disrupt many species and their habitat. In essence, if the magnitude (flow rate per unit time), frequency (how often high or low flows occur), duration (how long low or high flows persist), annual variation (variation from year to year), or daily variation (daily fluctuations in flow) of flow is outside natural bounds, many species that depend on specific patterns in streamflow can be imperiled.

Scientists in the NAWQA Project compiled and summarized ecological data collected at more than 800 streamgages with various types and severities of flow modification. Statistical models were developed, region by region, that describe the relation between stream health and streamflow modification (Carlisle and others, 2017, 2019). In most regions, the health of streams and rivers is increasingly impaired where flows are more severely modified.
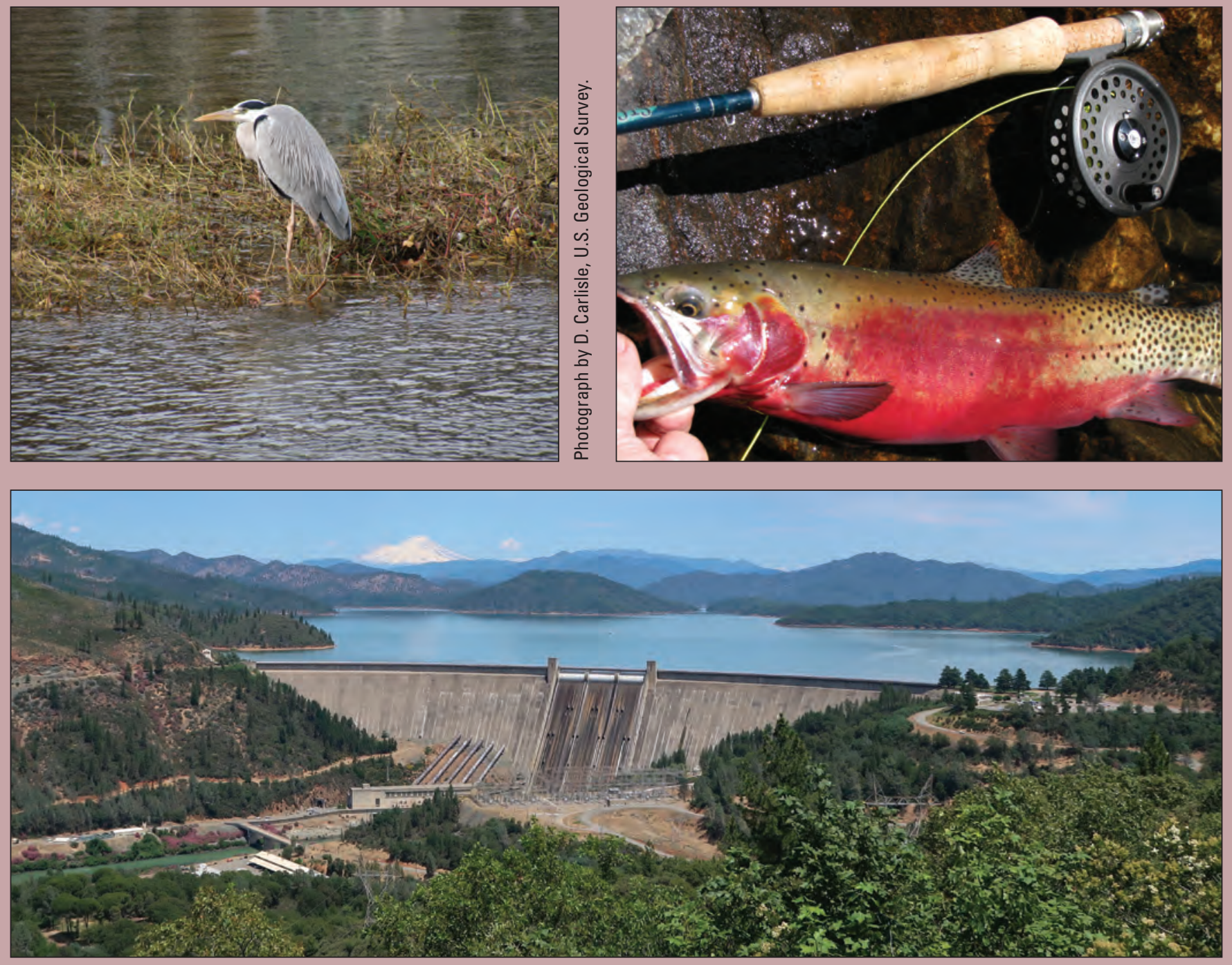

Streams and rivers provide habitat for wildlife (heron in upper left photograph) and recreational opportunities such as fishing (cutthroat trout in upper right photograph). It is therefore important to understand how changes in flow caused by water management (such as the Shasta Dam in lower photograph) can harm stream and river ecosystems. 


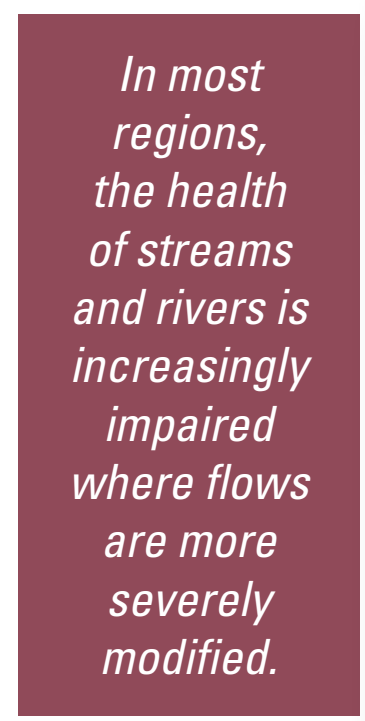

In most

the health

treams

and rivers is

creasingly

are more

severely

modified.

\section{Predicting the Ecological Consequences of Modified Streamflow}

Although it is generally well accepted that the health of streams and rivers depends on natural patterns in streamflow, management decisions benefit from an understanding of how specific changes to streamflow will affect stream health. This information allows decision makers and the public to better balance the needs of ecosystems and people. For example, imagine a dam has reduced low-flow magnitudes downstream, and changes to dam operations therefore are being considered. By understanding how increasing low-flow magnitudes will affect fish survival, the ecological benefits can be weighed against the potential economic costs of the operational changes.

Using hydrological and ecological monitoring data from the USGS and the U.S. Environmental Protection Agency, USGS scientists developed models that predict the ecological consequences of modified streamflow (Carlisle and others, 2019). Models were developed for each of the primary streamflow attributes covered in this report: magnitude, duration, frequency, annual variability of low and high flows, and daily flow fluctuation. The loss of native species (invertebrates and fish) was used as an indicator of stream health. Similar indicators are used by State and Federal agencies around the world.

Model predictions have an important caveat. Like all correlative analyses, these model predictions do not prove causality. Numerous factors, such as chemical pollution and invasive species, cause the loss of native species in the Nation's streams and rivers, and few of these factors were controlled for in the model-development process. In addition, modification of streamflow often harms stream ecosystems in indirect ways and over long periods. For example, reduced frequency of high flows leads to changes in the structure of the stream channel and available habitat, which may take decades to manifest. As consequence, it is important to realize that model predictions are purely based on associations between indicators of stream health and streamflow modification. Nonetheless, the models provide a prediction of how each streamflow attribute may be ecologically significant in different regions of the country and, overall, how natural streamflows are critical for maintaining the health of streams and rivers. Finally, these types of predictions, based on regional-scale observational data, are useful as a preliminary educated guess until more local, in-depth studies can be completed.

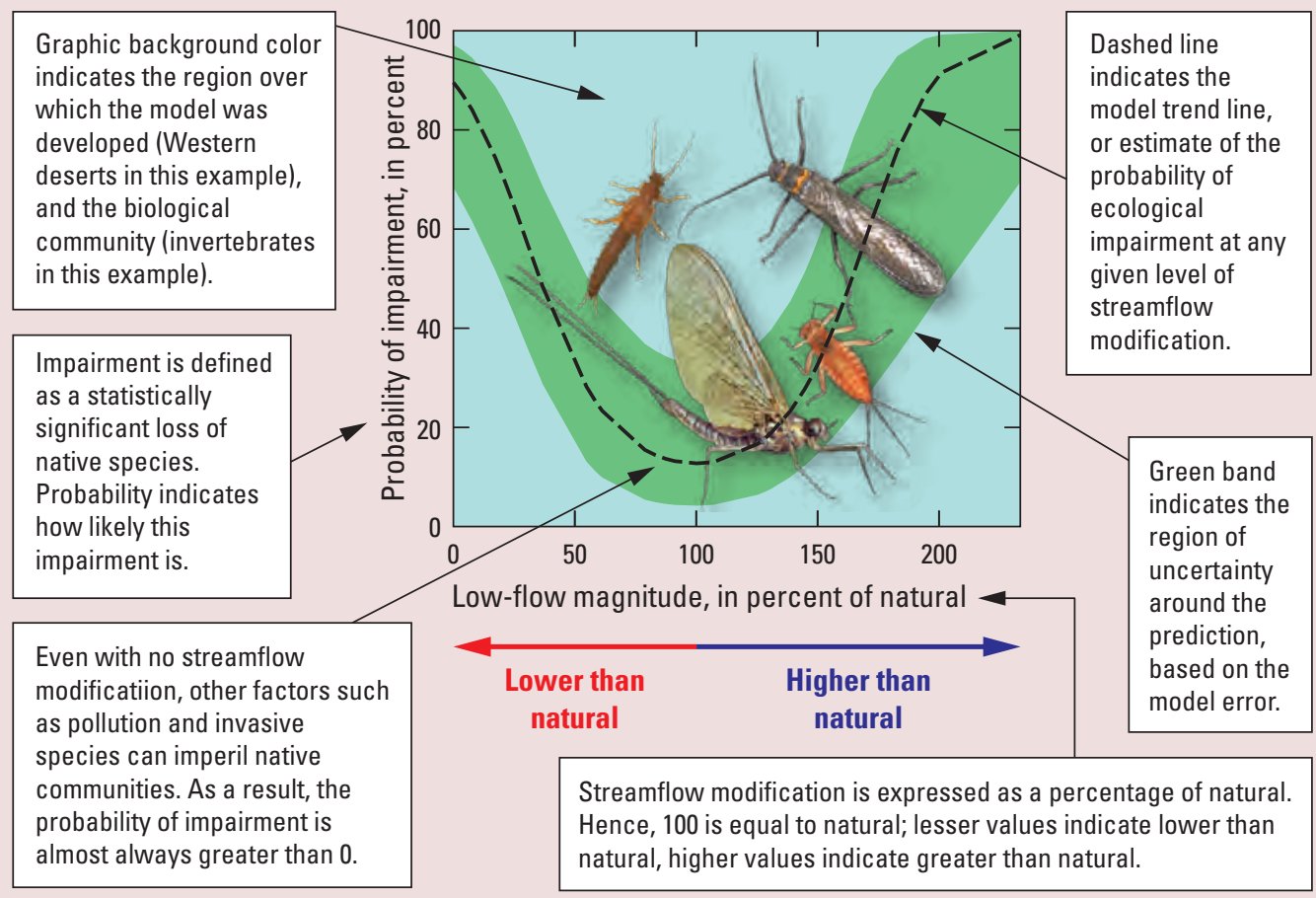




\section{Ecological Responses to Modification of Low-Flow Magnitude}

Stream health was related to how low-flow magnitude was modified and the severity of modification (Carlisle and others, 2019). In five regions, biological impairment was as much as five times more likely in streams where low-flow magnitudes were higher than natural (fig. E1). Stream biological communities in the western deserts, mountains, and plains were as much as nine times more likely to be impaired where low-flow magnitude was lower than natural.
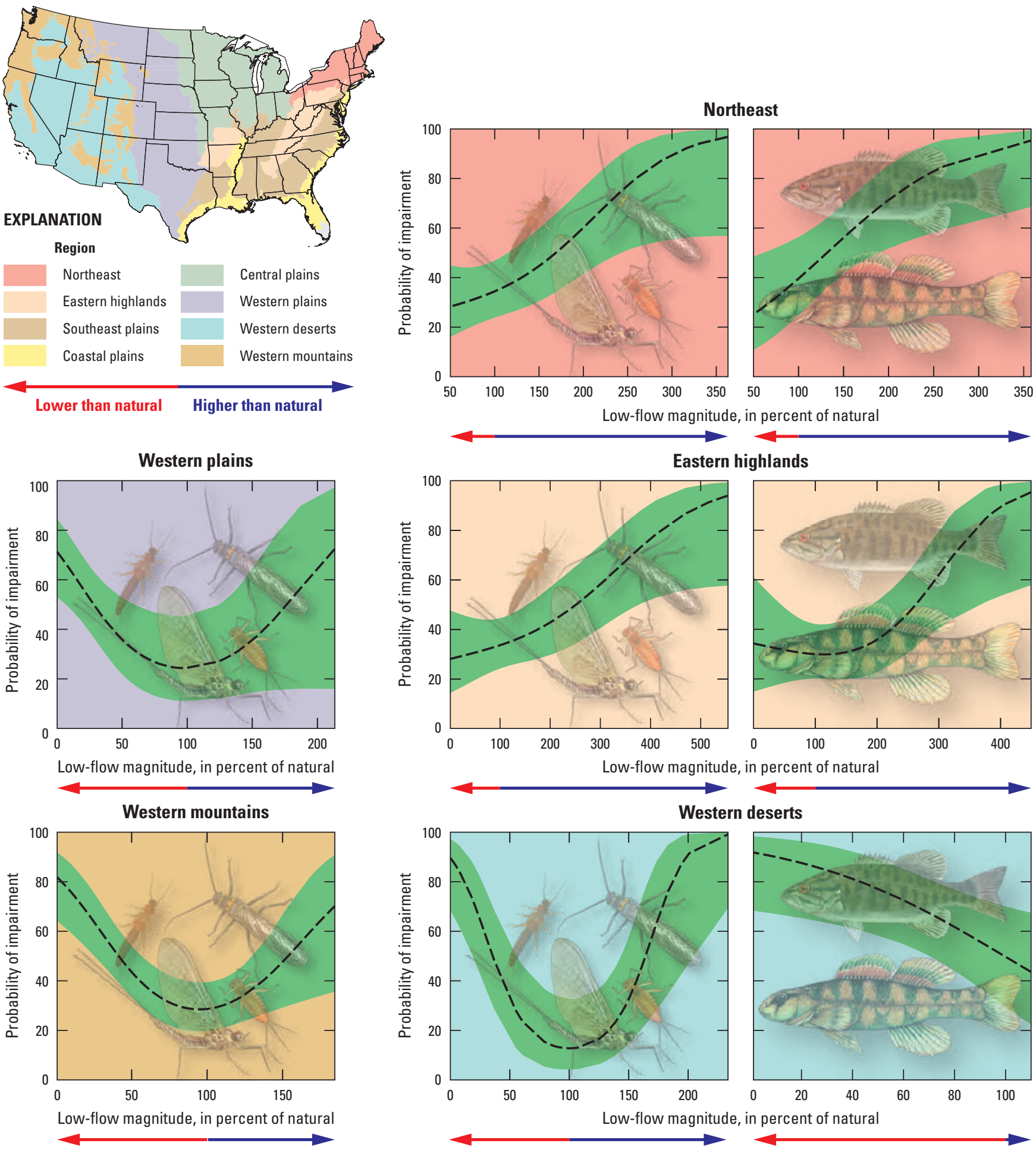

Figure E1. Modification of low-flow magnitude is predicted to impair invertebrate and fish communities in several regions. The dashed line shows the predicted likelihood that the community is impaired, which is defined as having lost a substantial number of native species. Green shading indicates the region of uncertainty in the predicted likelihood. 
Other research at local scales corroborates NAWQA's regional-scale findings and provides hints into the possible ways that stream health is harmed by the modification of low-flow magnitude. Modification of low flow by human activities harms aquatic species and stream health in several ways. Depleted low flows provide less dilution of pollutants that enter the stream from sources such as wastewater discharges (Rice and Westerhoff, 2017). Depleted low flows can cause habitat loss if parts of the streambed become dry, if flowing parts of the river become disconnected, or if water temperatures rise (Dewson and others, 2007; Grantham and others, 2012; Rolls and others, 2012). Finally, because the growth and survival of many species require periods of sustained low flows, higher than natural low flows can profoundly affect the survival and reproduction of native species and promote nonnative and invasive species (Freeman and others, 2001; Bunn and Arthington, 2002; Warren and others, 2015).

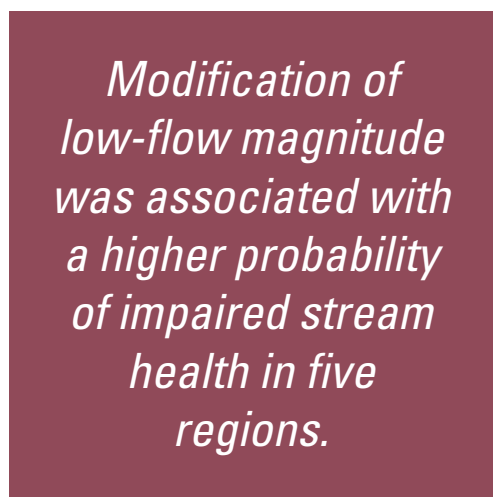

\section{Ecological Responses to Modification of High-Flow Magnitude}

Impaired ecological health was increasingly likely in streams with lower than natural magnitudes of high flows (Carlisle and others, 2017, 2019). In four regions, biological communities were as much as four times more likely to be impaired in streams with reduced (relative to natural) high-flow magnitude (fig. E2). The harmful ecological consequences of highflow modification are well known (Webb and others, 2013). Many studies have indicated how reduced high-flow magnitude harms ecological health in streams (Olden and others, 2014). Periodic high flows are essential for maintaining healthy stream
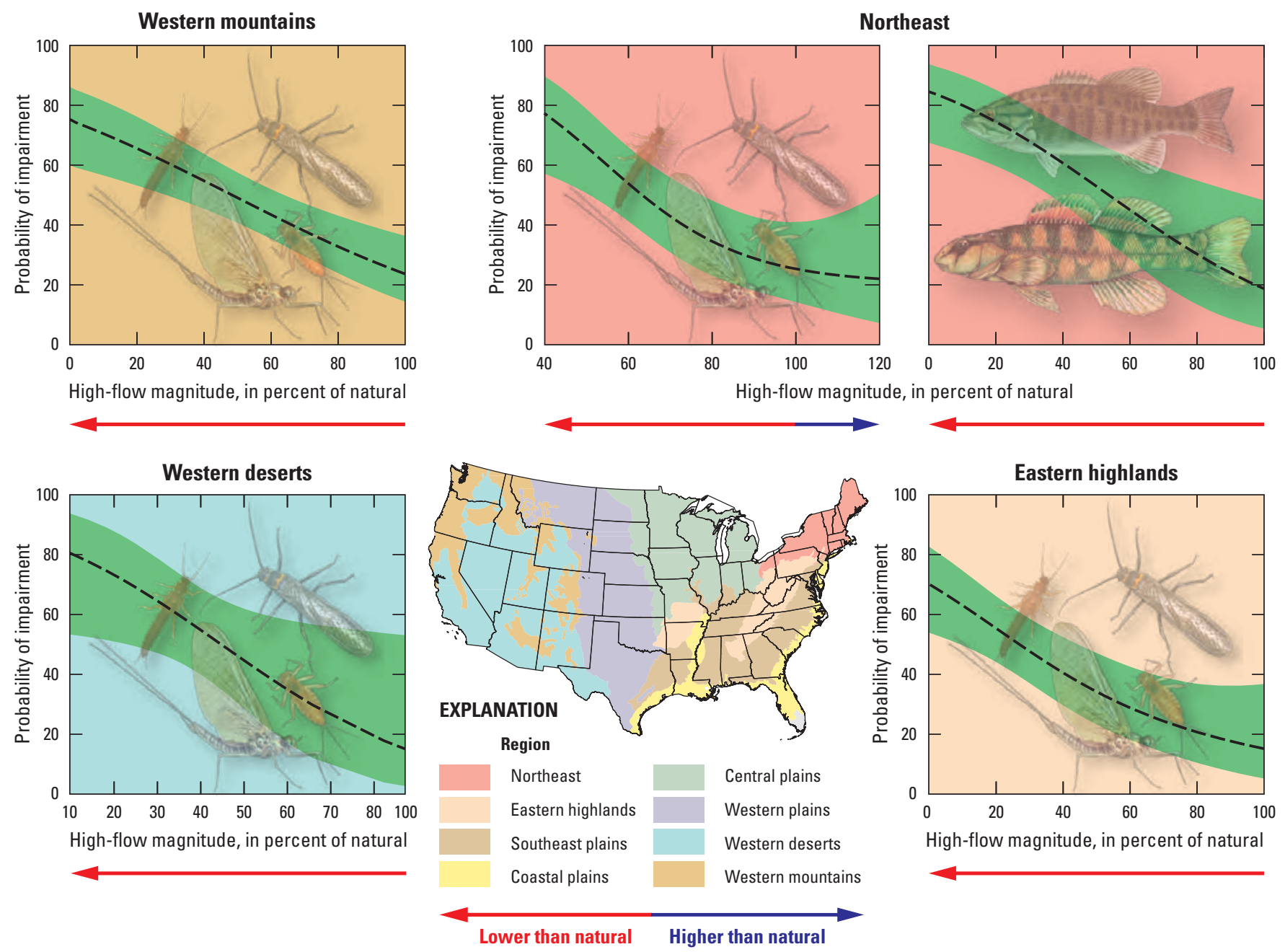

Figure E2. Modification of high-flow magnitude is predicted to impair invertebrate and fish communities in several regions. The dashed line shows the predicted likelihood that the community is impaired, which is defined as having lost a substantial number of native species. Green shading indicates the region of uncertainty in the predicted likelihood. 


\section{The Magnitude and Timing of Flows Is Critical to Stream Health}

In addition to the magnitude of high flows, the timing of high flows is important to stream ecosystems. NAWQA conducted a focused regional study in the southern Rocky Mountains to investigate how altered streamflow affects stream health. Results showed the diversity of sensitive insect species - such as mayflies, stoneflies, and caddisflies - was reduced in streams where the timing of high flows was modified relative to natural conditions. Under natural conditions, peak flows in Rocky Mountain streams occur in May and June as the snowpack melts. Flows decline through the remainder of the summer and autumn and are lowest during winter.

Streamflows in the Williams Fork and Rio Grande are controlled by upstream storage reservoirs. Stored water is released down the Williams Fork throughout the summer, which causes unnaturally high flows. In contrast, summer flows in the Rio Grande are typically depleted as water is stored in the reservoir. The diversity of aquatic insects was reduced in these and other streams where the magnitude of flows during summer was either higher or lower than natural. The reasons for this loss of biological diversity remain unknown, but there are several possible explanations. First, August is important to many aquatic species in Rocky Mountain streams because it is the period when streamflows are relatively stable and water temperature is the warmest under natural conditions. August is therefore a short but critical period for growth and development of offspring. Unnaturally high flows in August may disrupt feeding or reduce food availability, whereas unnatural low flows may limit habitat and cause overcrowding and competition for food. Second, altered flows are often associated with altered water temperature. Many insects require sufficient warming of the water to grow during the summer, as well as sufficiently cold water during the winter as they "hibernate" as eggs. Reservoirs often release water that is colder in the summer and warmer in the winter, relative to natural conditions.
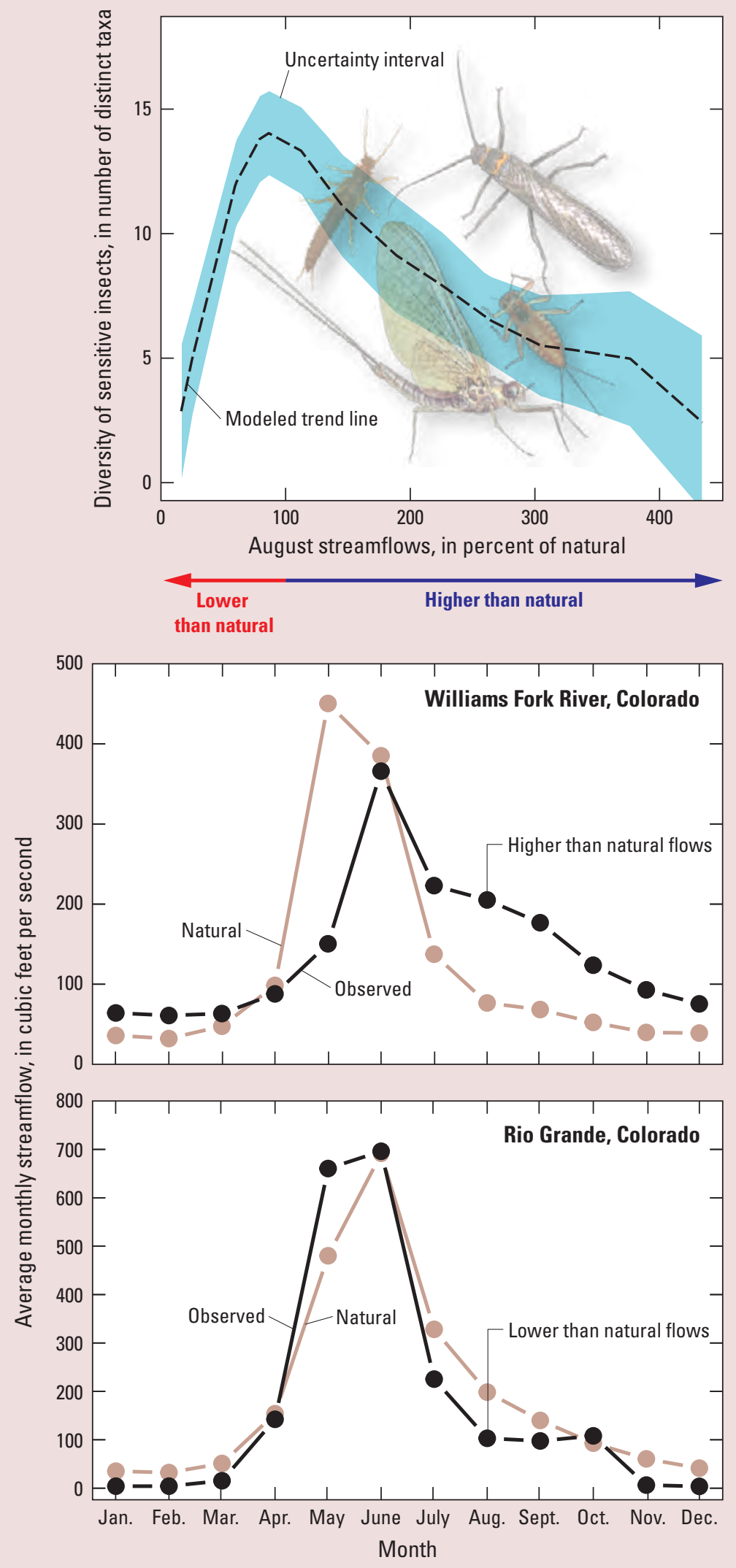
ecosystems, and for maintaining human health as well. Ancient Egyptians understood that the success of their food production depended on the annual floods of the Nile River to replenish soil nutrients. In modern times, however, periodic flooding and resulting property damage have compelled people around the world to build flood-control reservoirs. Yet periodic high flows serve many important roles in maintaining healthy streams and rivers; for example, high-flow events flush out accumulated sediment that would otherwise smother rocky stream bottoms. High flows also add cobble and woody debris that provide habitat for many species and reconnect the river with biological communities on the floodplain when flows overtop streambanks (Poff and others, 1997; Juracek, 2014).
Periodic high flows (floods) can damage property and imperil human lives but are essential to maintain healthy streams and rivers.

\section{Ecological Responses to Modification of High-Flow Duration}

Stream health was related to how high-flow duration was modified and the severity of the modification (Carlisle and others, 2017, 2019). In the northeast and plains (central, southeast, and coastal), biological communities were as much as nine times more likely to be impaired in streams where the duration of high flows was shorter than natural (fig. E3). In contrast, a longer than natural duration of high flows in the plains was associated with a four-fold increase in the probability of biological impairment. No associations between stream health and low-flow duration were determined for any regions, although other studies have determined low-flow duration to be ecologically important locally (Miller and others, 2007; James and Suren, 2009).

Just as high-flow magnitude is important to stream health, so is high-flow duration - the length of time high flows persist. In fact, the ecological benefits of high-flow events may depend on their duration. For example, high flows spread out into river floodplains, creating shallow water areas where some fish lay their eggs_-because the newly hatched fish need to spend some time in the relative safety of these shallows before returning to the river channel, any human-caused reduction in the duration
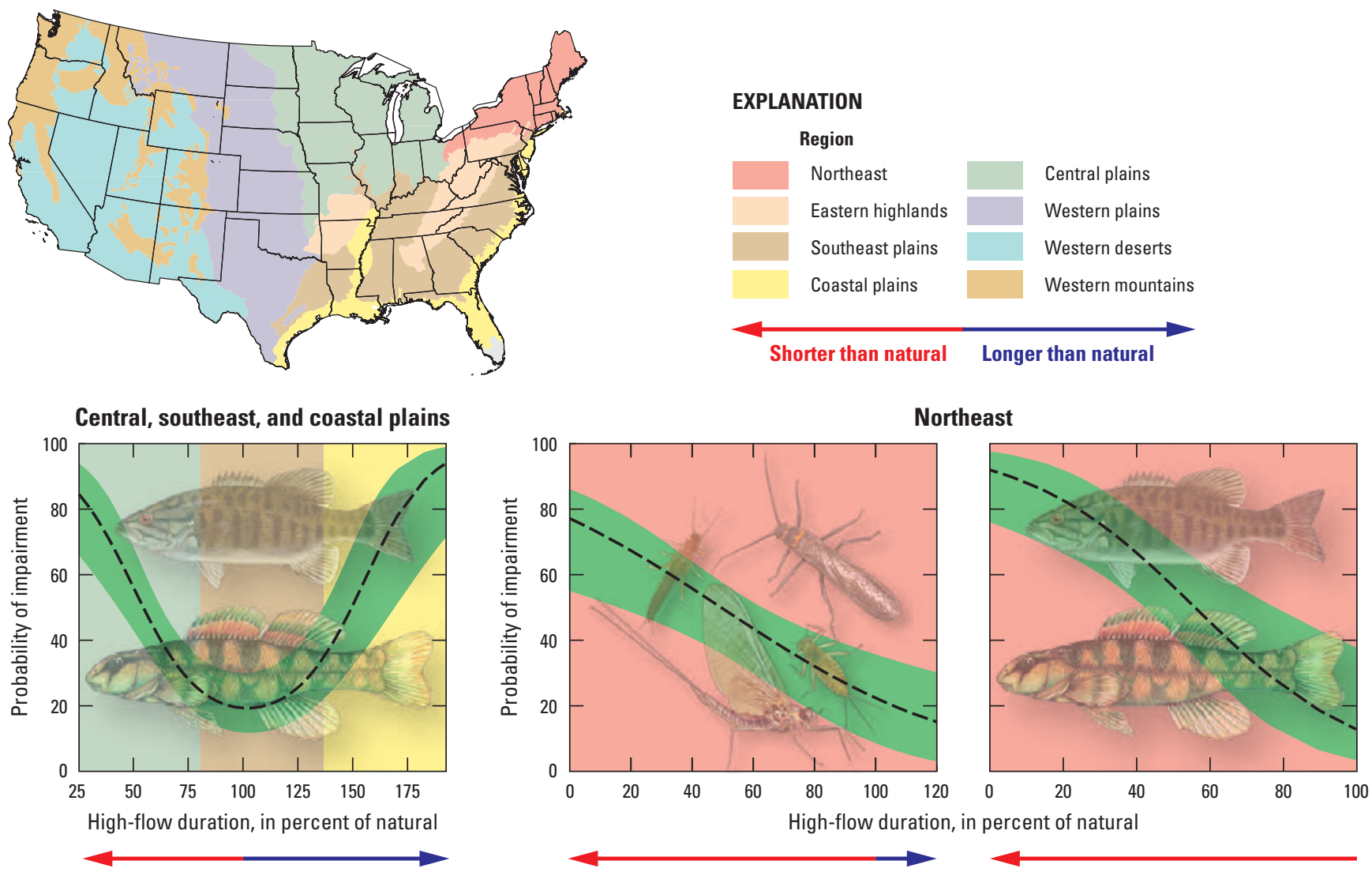

Figure E3. Modification of high-flow duration is predicted to impair invertebrate and fish communities in several regions. The dashed line shows the predicted likelihood that the community is impaired, which is defined as having lost a substantial number of native species. Green shading indicates the region of uncertainty in the predicted likelihood. 
of high flows would be harmful to their survival (Knight and others, 2014; Wootton and Smith, 2015). Longer than natural high-flow duration is often associated with dam management (Poff and others, 2006) and can harm ecosystems by changing the natural transitions from high to low flows, which are important to many species (for example, Kupferberg and others, 2012).

\section{In several regions, the modification} of high-flow duration was associated with a higher probability of impaired biological communities.

\section{High Flows During Spring May be Universally Important to Stream Health}

An assessment of more than 700 streams and rivers across the Nation supports the premise that naturally high flows during springtime are critical to ecological health (Carlisle and others, 2017). In streams where the magnitude of the highest springtime streamflows was less than 50 percent of natural, invertebrate communities were twice as likely to be impaired relative to streams with natural springtime flow magnitudes. Because this relationship was apparent across the many diverse types of streams and rivers in the Nation, it may indicate a universally important factor for the maintenance of stream health.

Rising streamflows accompanied by warming water temperature in the spring are important life-history cues for many stream-dwelling species (Tockner and others, 2000). For example, most North American aquatic insects reproduce in spring (Vieira and others, 2006), and successful egg laying and hatchling survival often requires synchrony with rising or falling water levels (Peckarsky and others, 2000). Evidence exists that high spring flows promote invertebrate
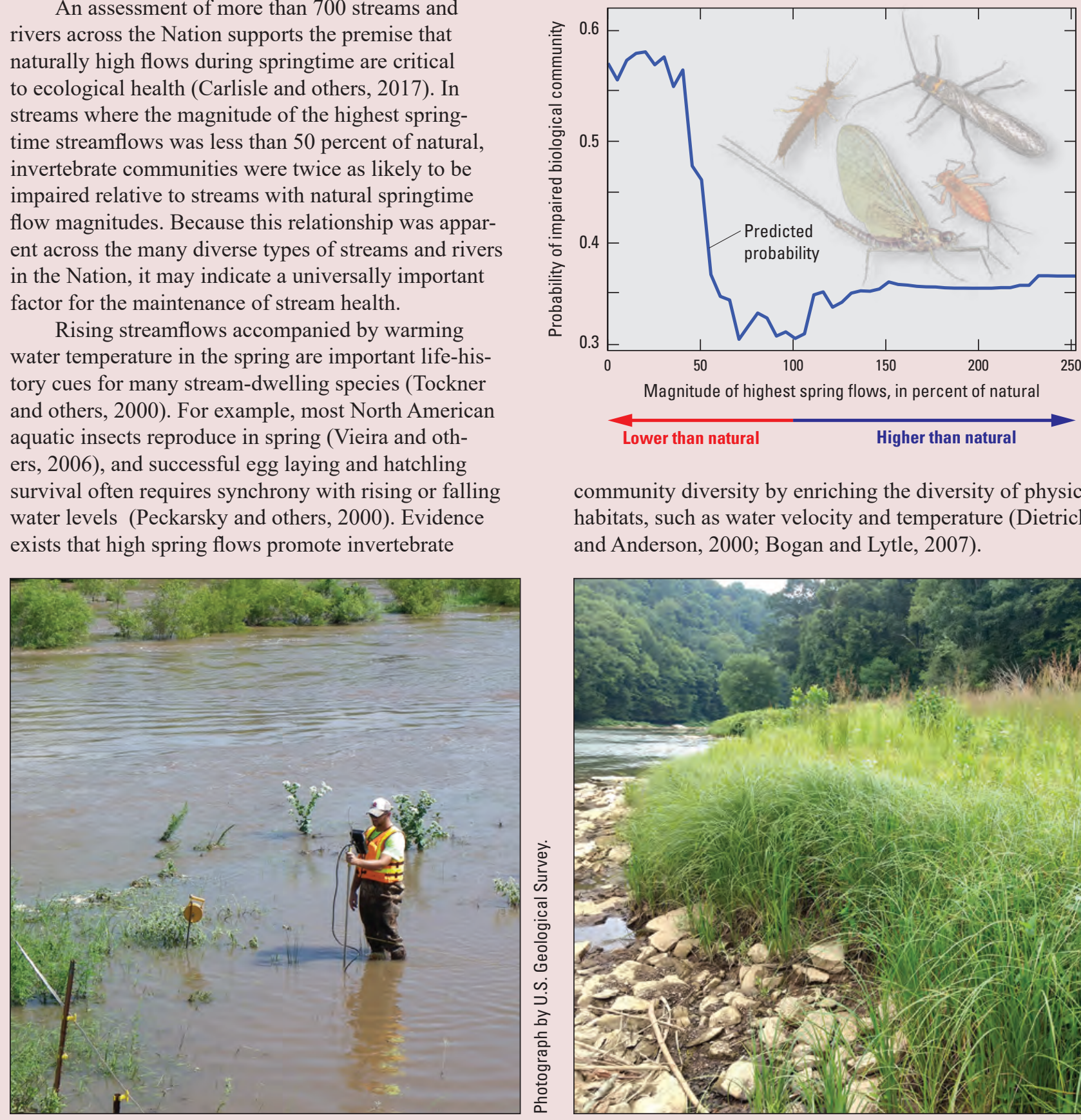

community diversity by enriching the diversity of physical habitats, such as water velocity and temperature (Dietrich and Anderson, 2000; Bogan and Lytle, 2007).

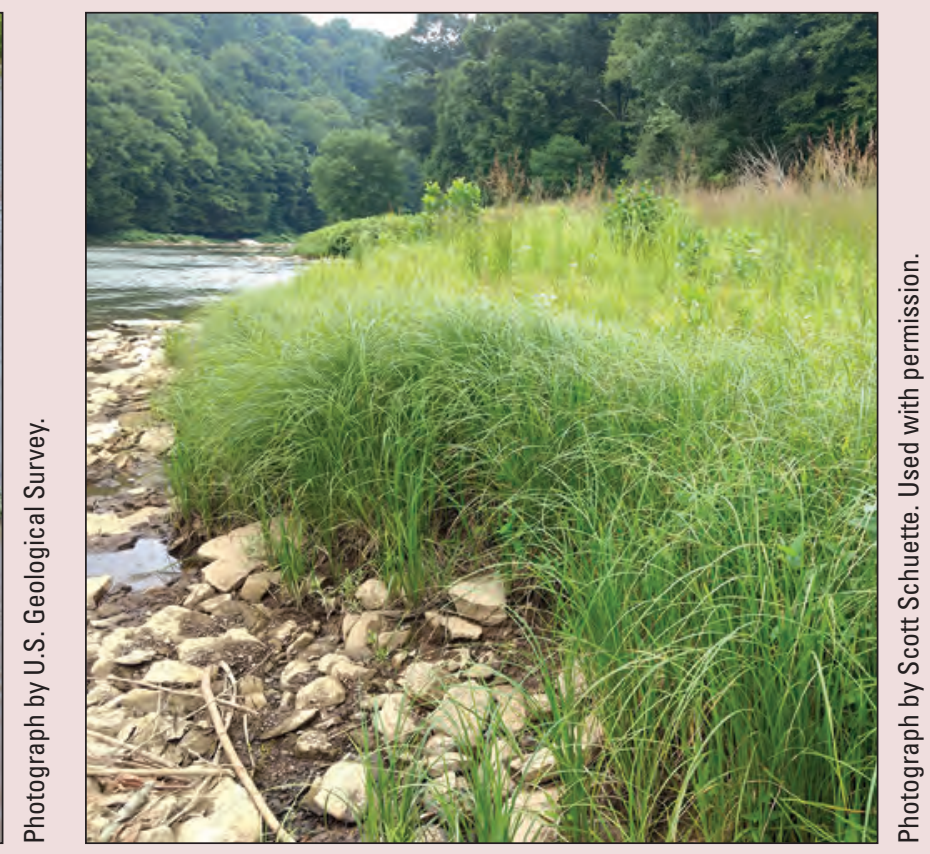

USGS hydrologist measuring high flows.

Vegetation colonizing a river bank after high flows subside. 


\section{When Streamflow Magnitude and Duration are Modified, Water Quality and Other Physical Conditions Change Too}

Streamflow modification is rarely the only human effect on stream health. Streamflows in the Neversink River, New York, and the Lehigh River, Pennsylvania, are modified by reservoirs. Water is removed from the reservoir on Neversink River to provide drinking water for major metropolitan areas, whereas the reservoir on Lehigh River was developed to control flooding. After the reservoirs were constructed, the magnitude of high flows was reduced significantly in both rivers, but that is where the similarities end. In the Neversink River, low-flow magnitude after reservoir construction has typically been 10 times higher, and the duration 3 times longer than would occur naturally. Furthermore, because water is released from the depths of the reservoir, summertime water temperature is 7 degrees Celsius cooler than natural. In contrast, low-flow magnitude in the Lehigh River is 4 times higher, and the duration is 2 times shorter than natural conditions, and stream water temperature is not modified. The contrast in invertebrate communities between these two rivers is profound. A total of 20 percent of invertebrate species have been eliminated from the Lehigh River, but nearly 70 percent have been eliminated from the Neversink River. Although the exact causes are unclear, the combined effects of modified flows and water temperature are likely contributors to the loss of diversity in the Neversink River.

Daily streamflows in Neversink River compared to natural conditions

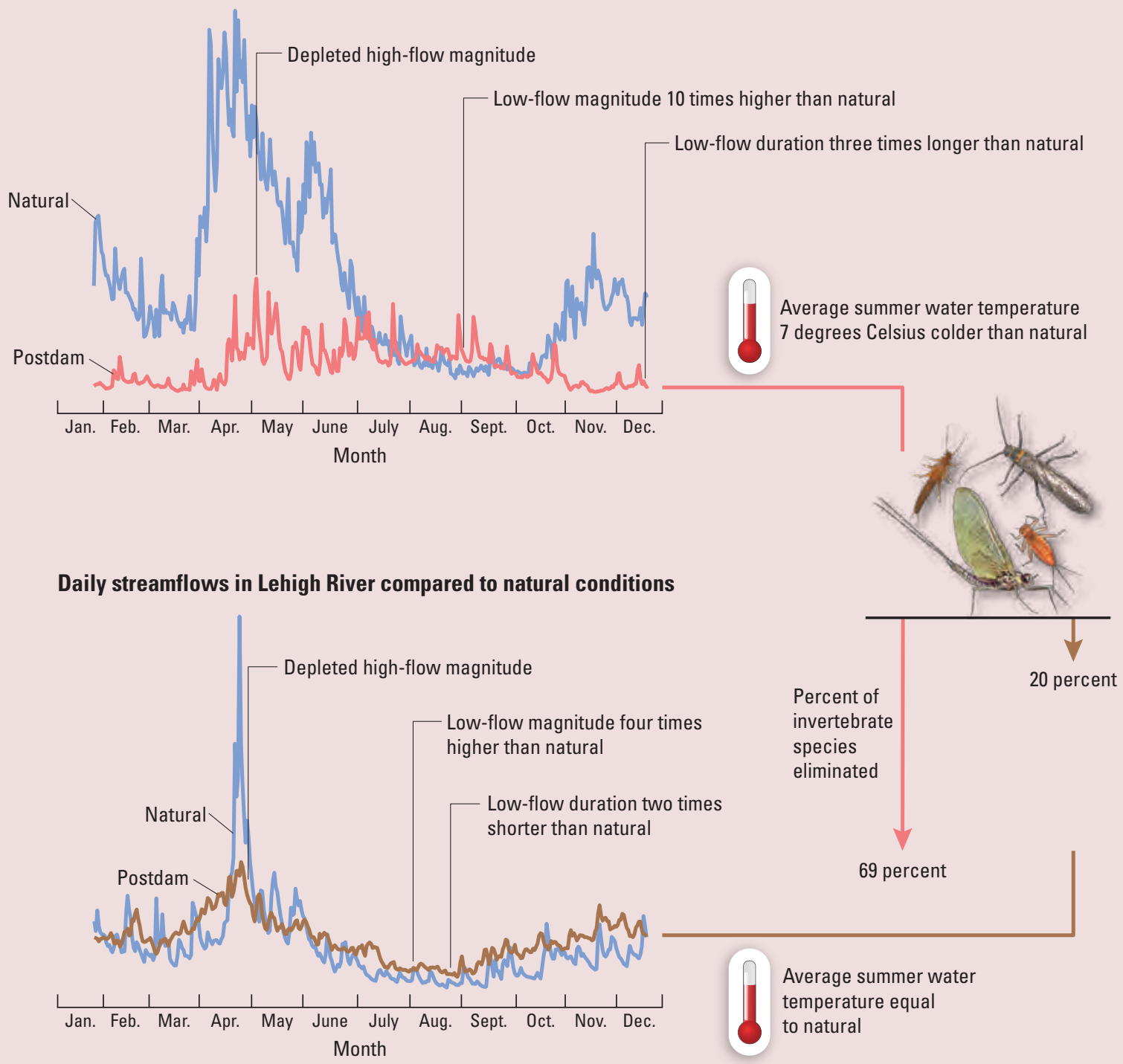


Modified

frequency of

low flows was

associated

with a higher

probability of

impaired stream

health in two

regions.

\section{Ecological Responses to Modification of Low-Flow Frequency}

Ecological health in two regions was reduced in streams with modified low-flow frequency. In the eastern highlands and northeast, biological communities were as much as twice as likely to be impaired in streams where low flows were more frequent than natural (fig. E4). There was no evidence that low flows that are less frequent than natural have a negative ecological effect in any region.

Some low flows during the year can be beneficial for many aquatic species, but if low flows are too frequent, they can be harmful, especially if those low flows are during seasons that normally would have higher streamflow. For example, low flows can cause juvenile fish to be crowded into less desirable habitats where the fish are more vulnerable to predators and have less food. If low-flow events like these occur repeatedly, they can substantially reduce fish populations. Species unable to cope with the harshness of low-flow conditions can be eliminated (Finn and others, 2009).
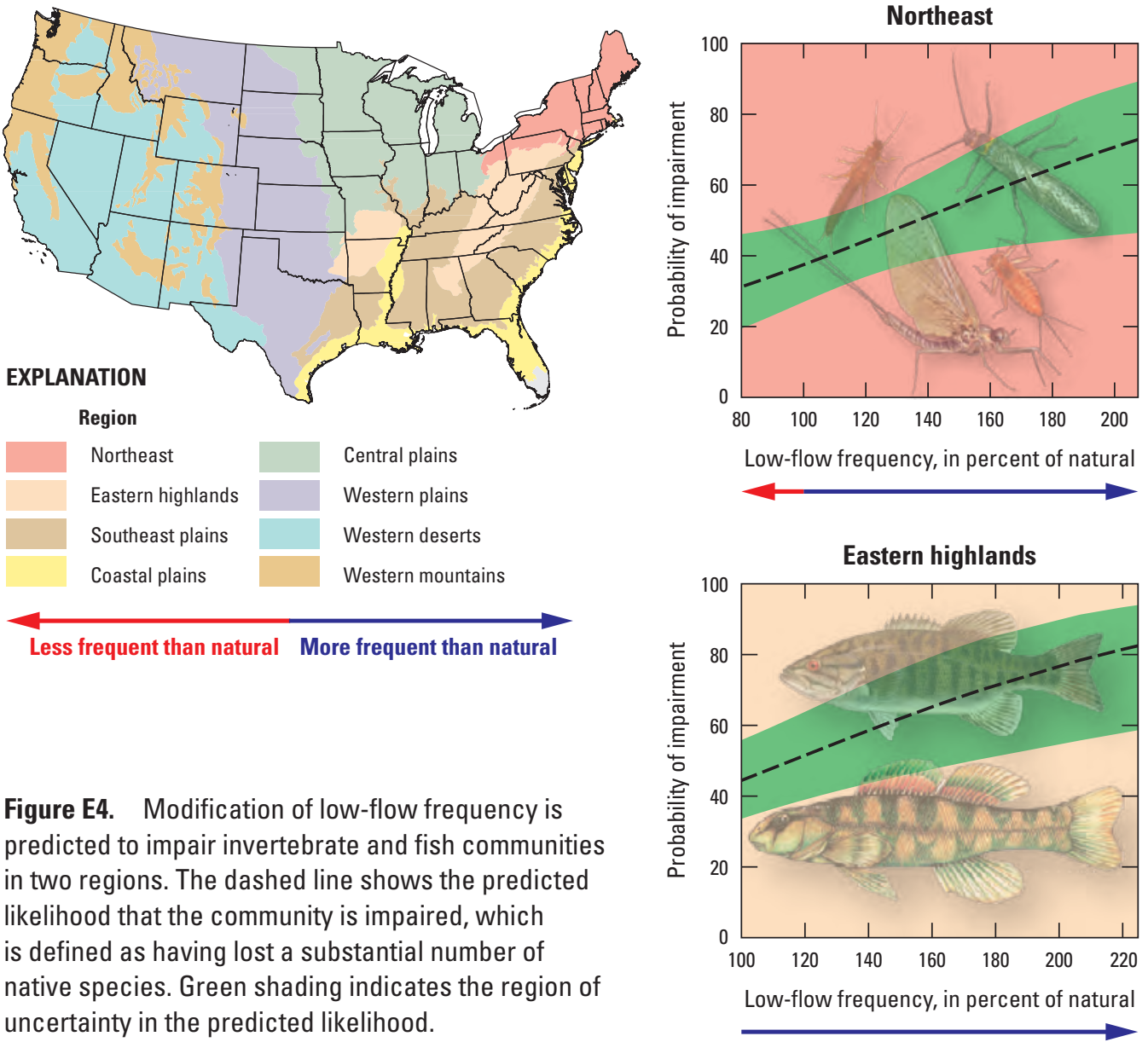

Figure E4. Modification of low-flow frequency is predicted to impair invertebrate and fish communities in two regions. The dashed line shows the predicted likelihood that the community is impaired, which is defined as having lost a substantial number of native species. Green shading indicates the region of uncertainty in the predicted likelihood. 


\section{Ecological Responses to Modified High-Flow Frequency}

Ecological health in three regions was reduced in streams with modified high-flow frequency. In the western deserts, northeast, and eastern highlands, biological communities were as much as four times more likely to be impaired in streams where high flows were either less or more frequent than natural (fig. E5).

High flows that are more frequent than natural can be detrimental to stream health by scouring the stream bottom and displacing organisms and by causing erosion in the stream channel that degrades habitat quality (Walsh and others, 2005). When high flows are less frequent than natural, the benefits of high flows are only rarely realized. Under natural conditions, flows that are high enough to reshape the stream channel, bring woody debris into the stream, and nourish plants and animals along the floodplain occur only every 2 to 3 years. These high flows contribute to the creation of habitats that then are used for several years by many invertebrate and fish species, building and maintaining healthy population levels. Over time, though, these habitats deteriorate unless they are restored by occasional high flows.

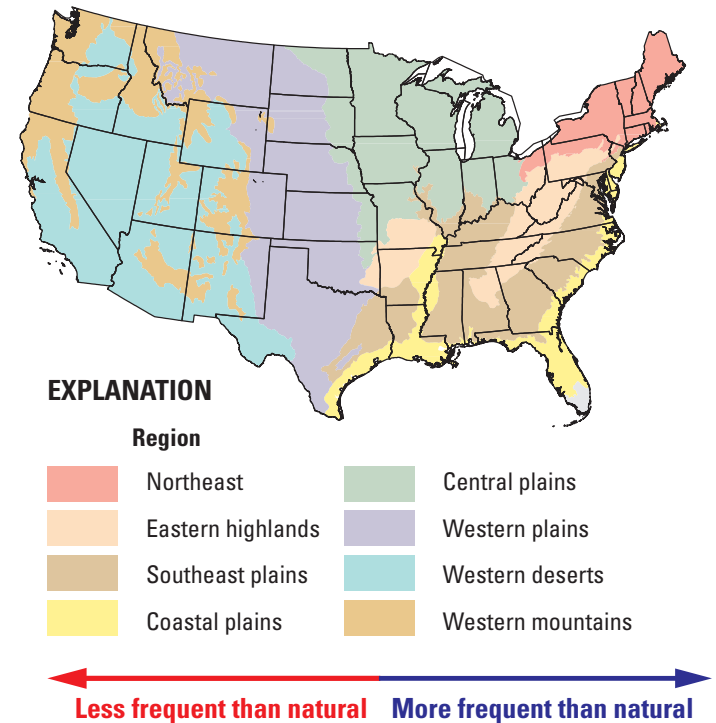

\section{Modified frequency of high flows was associated with a higher probability of impaired stream health in three regions.}
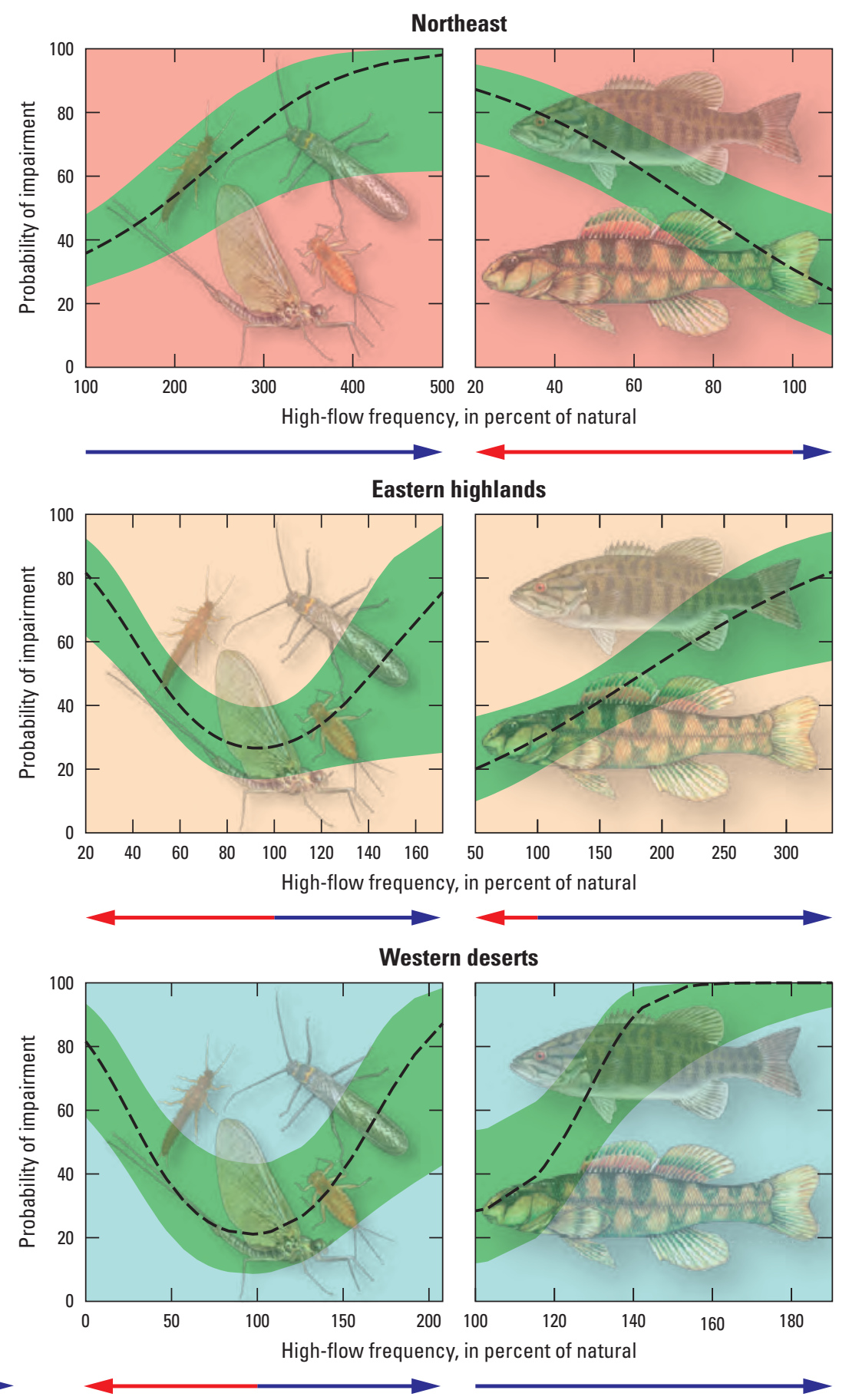

Figure E5. Modification of high-flow frequency is predicted to impair invertebrate and fish communities in several regions. The dashed line shows the predicted likelihood that the community is impaired, which is defined as having lost a substantial number of native species. Green shading indicates the region of uncertainty in the predicted likelihood. 


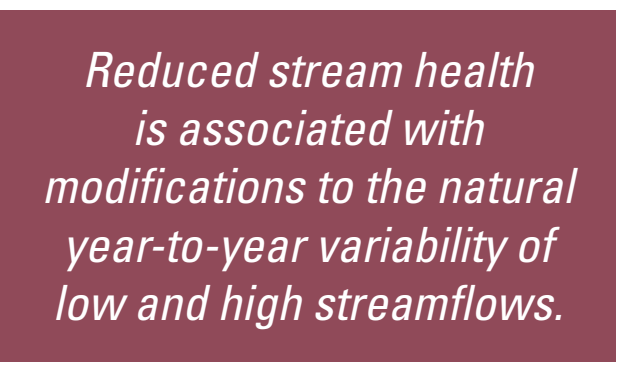

\section{Ecological Responses to Modified Annual Variability of Flows}

Ecological health in two regions was reduced in streams with modified lowflow variability. Biological communities in the northeast and eastern highlands were as much as three times more likely to be impaired in streams where low flows were more variable than natural (fig. E6). Similarly, biological communities in the northeast and eastern highlands regions were as much as three times more likely to be impaired in streams where low flows were less variable than natural.

Ecological health in four regions also was reduced in streams with modified highflow variability. Biological communities in the western mountains, western plains, northeast, and eastern highlands were as much as five times more likely to be impaired in streams where high flows were less variable than natural (fig. E7). Biological communities in the western mountains and western plains were twice as likely to be impaired in streams where high flows were more variable than natural.

Previous studies have documented the ecological importance of annual variability of streamflows (Yarnell and others, 2015). The ecological health of streams and rivers depends on annual variability of streamflow magnitude. Annual variability in streamflows is typically caused by variability in weather from year to year and creates occasional disturbances to river ecosystems. These periodic disturbances maintain diverse habitats that provide opportunities for a wider array of species (Naiman and others, 2008).
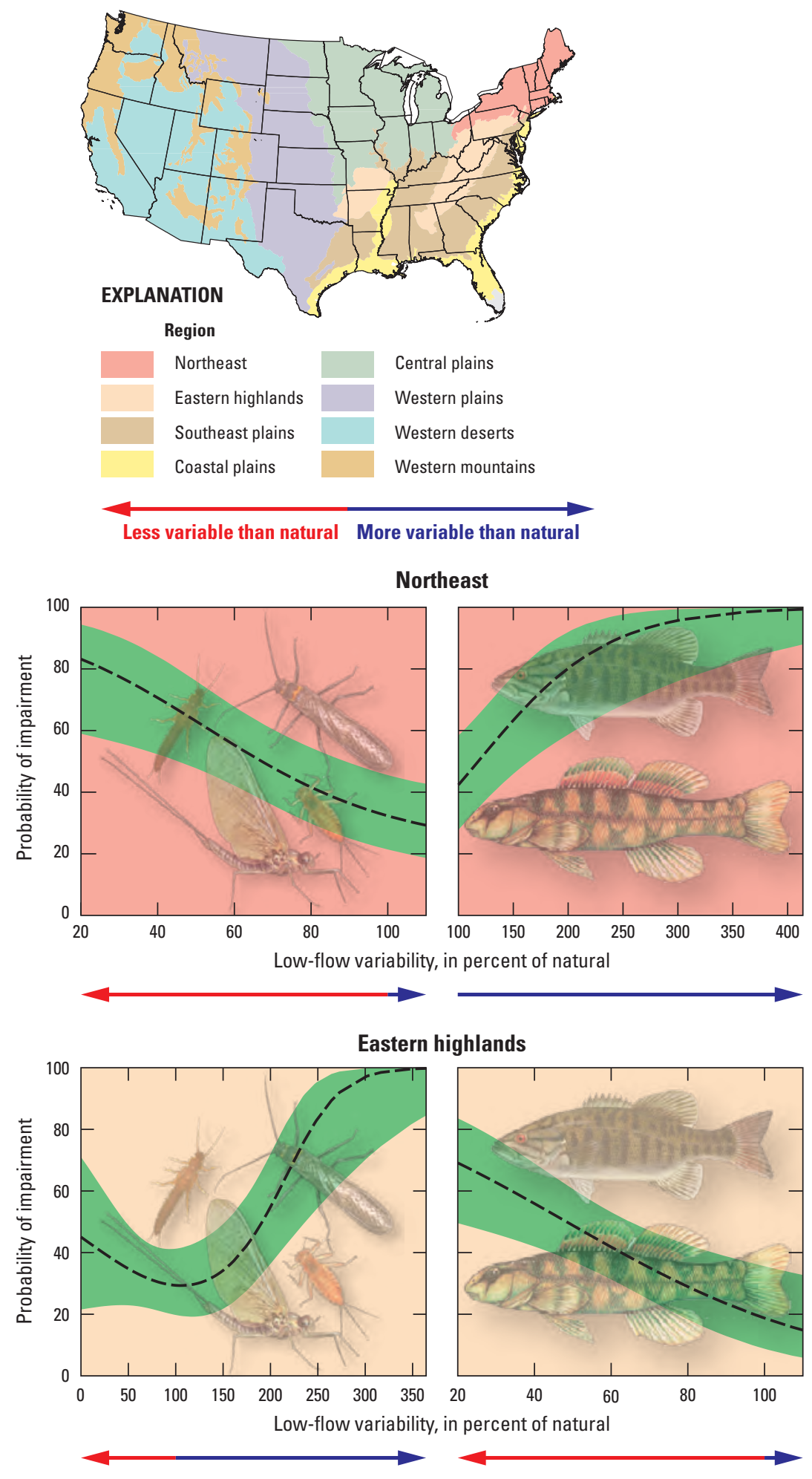

Figure E6. Modification of low-flow variability is predicted to impair invertebrate and fish communities in two regions. The dashed line shows the predicted likelihood that the community is impaired, which is defined as having lost a substantial number of native species. Green shading indicates the region of uncertainty in the predicted likelihood. 

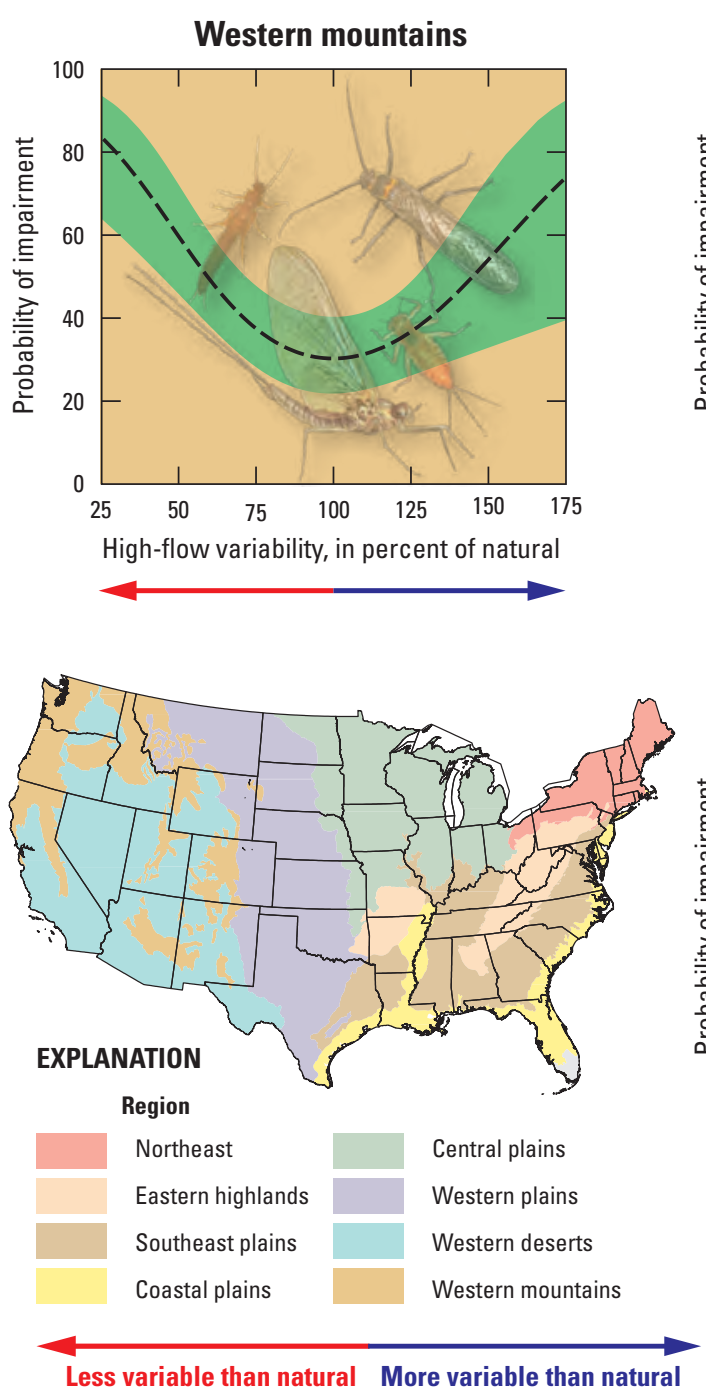

Figure E7. Modification of high-flow variability is predicted to impair invertebrate and fish communities in several regions. The dashed line shows the predicted likelihood that the community is impaired, which is defined as having lost a substantial number of native species. Green shading indicates the region of uncertainty in the predicted likelihood.
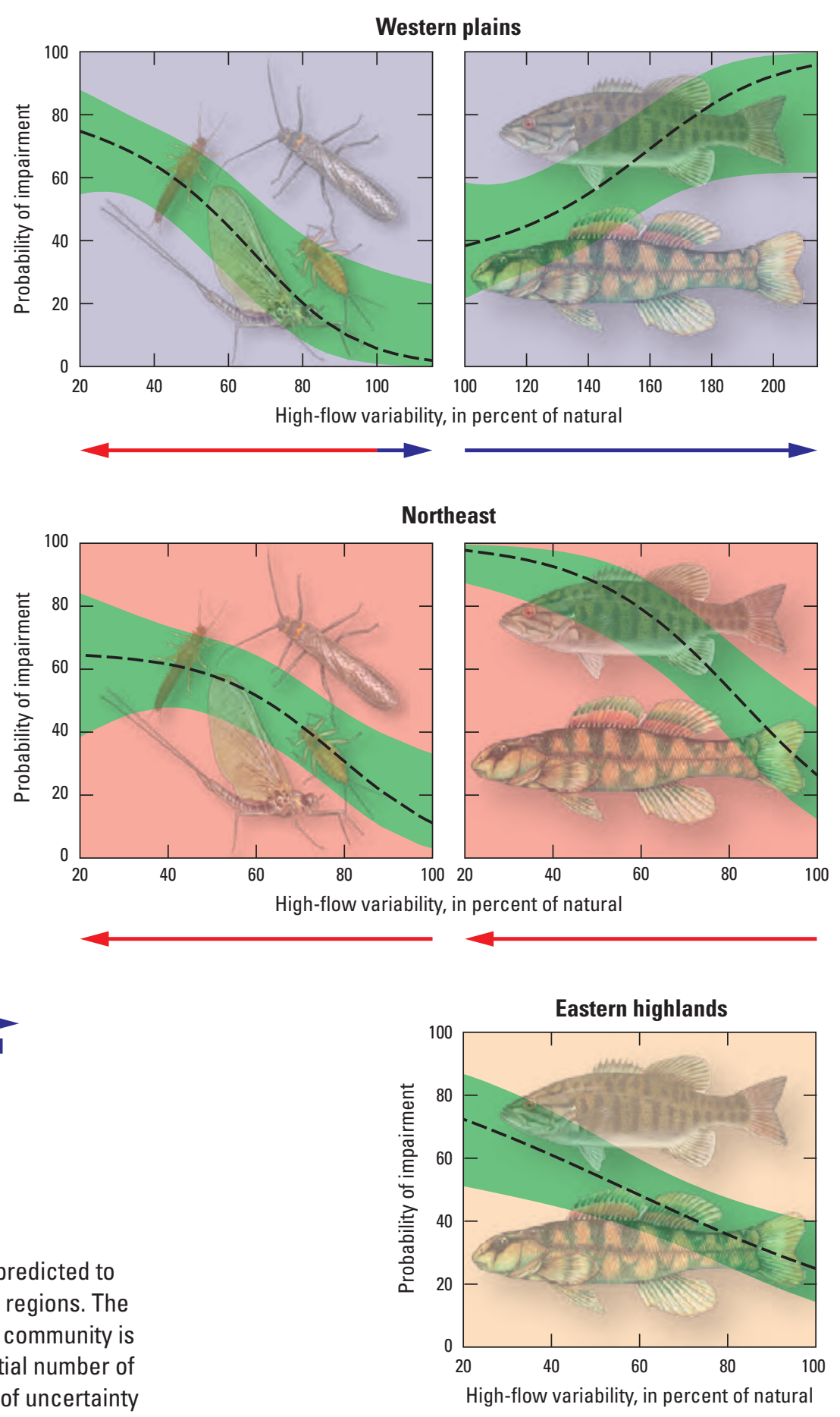


\section{Health of Stream Invertebrates in the Sierra Nevada Mountains Related to Annual Variability of High Flows}

By studying streams in the Sierra Nevada Mountains, U.S. Geological Survey scientists learned how flows modified by dams and diversions affect ecological health (Carlisle and others, 2015). Some streams had high flows that were less variable than natural, and others had high flows that were more variable than natural, but in either situation, the invertebrate communities in these streams were more likely to be impaired. It seems that the "Goldilocks Principle" applies to the relation between high-flow variability and invertebrate communities - just the right amount of annual variation is required to maintain healthy invertebrate communities. Unfortunately, little is known about the life histories of invertebrate species that inhabit streams - when they reproduce, what environmental conditions are needed for offspring to survive - so it is unclear why this "Goldilocks Principle" applies. According to ecological theory, though, an intermediate amount of disturbance should provide the optimal amount of habitat diversity, which in turn supports the greatest species diversity. Because high flows are considered a disturbance to stream ecosystems, the theory may apply here.

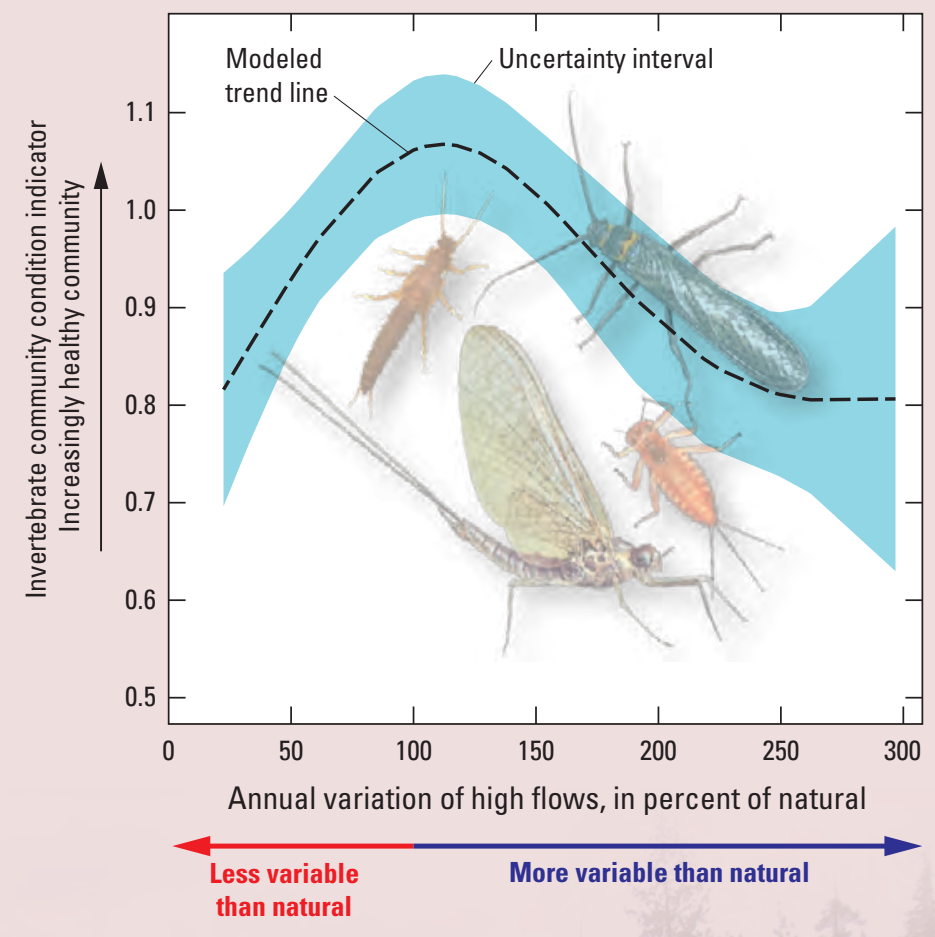

View of a diversion dam in the Sierra Nevada Mountains, California. Photograph by D. Carlisle, U.S. Geological Survey. 


\section{Ecological Responses to Modified Daily Flow Fluctuation}

Ecological health in three regions was reduced in streams with modifications to daily flow fluctuations. Biological communities in the western plains, western deserts, and eastern highlands were as much as four times more likely to be impaired in streams where daily flow fluctuations were higher than natural (fig. E8). Flows that fluctuate greatly on a daily basis can harm stream organisms in many ways. Juvenile fish and other organisms living in the streambed can be disturbed by sudden or frequent rises in flow. Rapid increases in flow are often followed by a rapid decline, which can leave bottom-dwelling organisms stranded above water, particularly those species unable to move rapidly enough to stay submerged as water levels drop (see sidebar on next page). Frequent flow fluctuations often cause gradual changes in physical habitat, such as erosion of stream banks, loss of streamside vegetation, and a decrease in range of sizes of rocks and sediment on the stream bottom. These changes, even when gradual, can make it much more difficult for aquatic species to survive (Melcher and others, 2017).
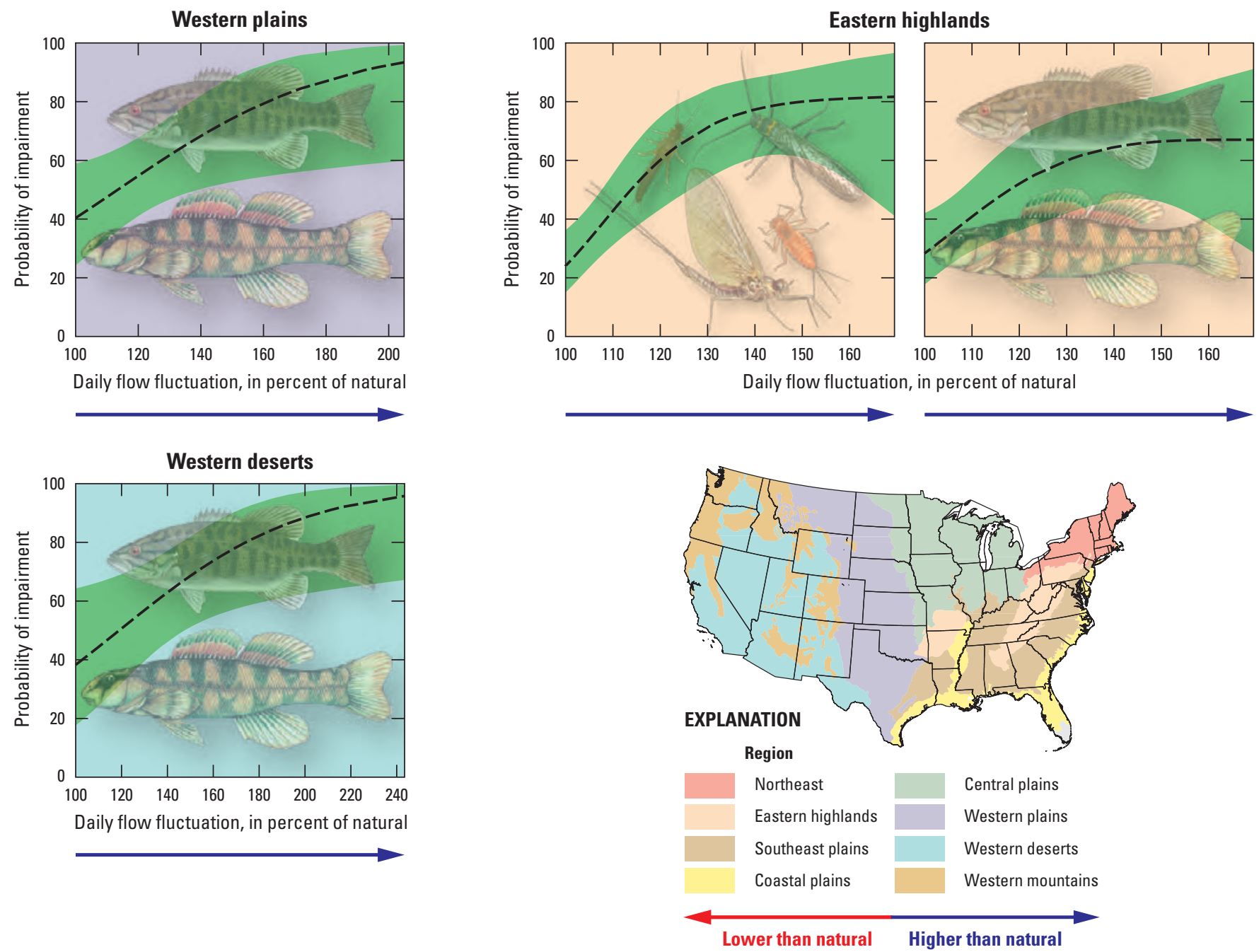

Figure E8. Modification of daily flow fluctuations is predicted to impair invertebrate and fish communities in several regions. The dashed line shows the predicted likelihood that the community is impaired, which is defined as having lost a substantial number of native species. Green shading indicates the region of uncertainty in the predicted likelihood. 


\section{Dam Operations Adjusted to Mitigate the Ecological Consequences of Streamflow Fluctuation}

In addition to streamflow fluctuation from one day to the next, flow also can fluctuate significantly from one hour to the next. This hourly fluctuation is typically minimal under natural conditions, but watermanagement practices such as hydroelectric power generation can cause extreme fluctuations from hour to hour because power is generated during the hours of peak electricity demand. The graph below shows streamflow releases from the Glen Canyon Dam on the Colorado River, which generates hydroelectricity. Each weekday, water is released from the dam to generate power beginning in the morning hours and continuing through the day. After midnight, water releases are reduced because electricity demand is less during the night.

Extreme hourly fluctuations in streamflow create an artificial "intertidal" zone along river margins, where the river bed is dewatered each day. Many species of aquatic insects lay their eggs along river margins, but those eggs cannot survive exposure to the air. As a result, these species are unable to persist in rivers with high-flow fluctuations (Kennedy and others, 2016).

Management of the Glen Canyon Dam is continually updated and adjusted as science provides new information about the needs of the Colorado River ecosystem, and those needs are balanced with the operating requirements of the reservoir with respect to water delivery and power generation. The U.S. Geological Survey Grand Canyon Monitoring and Research Center partners with agencies, academia, and citizen scientists to provide scientific information to dam manag-

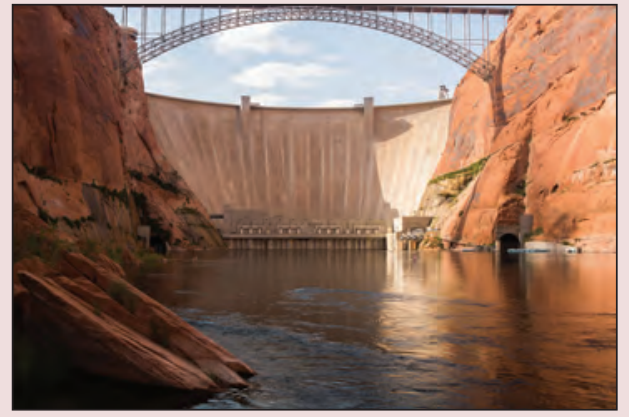
ers (https://www.gcmrc.gov). After a study that showed how hourly

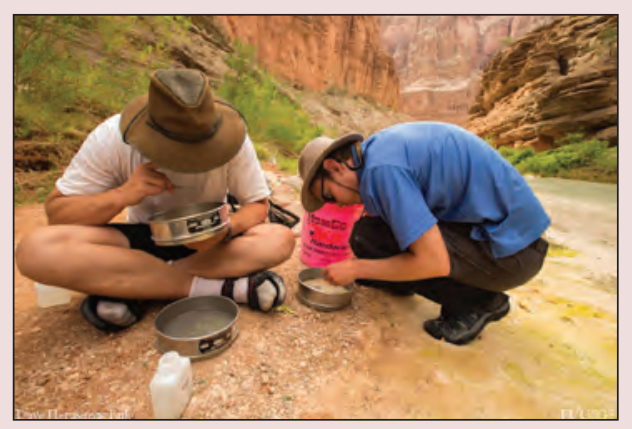

Top photograph: Glen Canyon Dam on the Colorado River. Lower photograph: Citizen science volunteers examining invertebrates collected in the Colorado River. streamflow fluctuation was detrimental to the aquatic insects upon which the river ecosystem depends (Kennedy and others, 2016), water releases from the dam were adjusted to provide more stable flows during periods when the demand for power generation was lowest. The U.S. Geological Survey and citizen science volunteers are monitoring the ecological outcomes of this new flow regime.

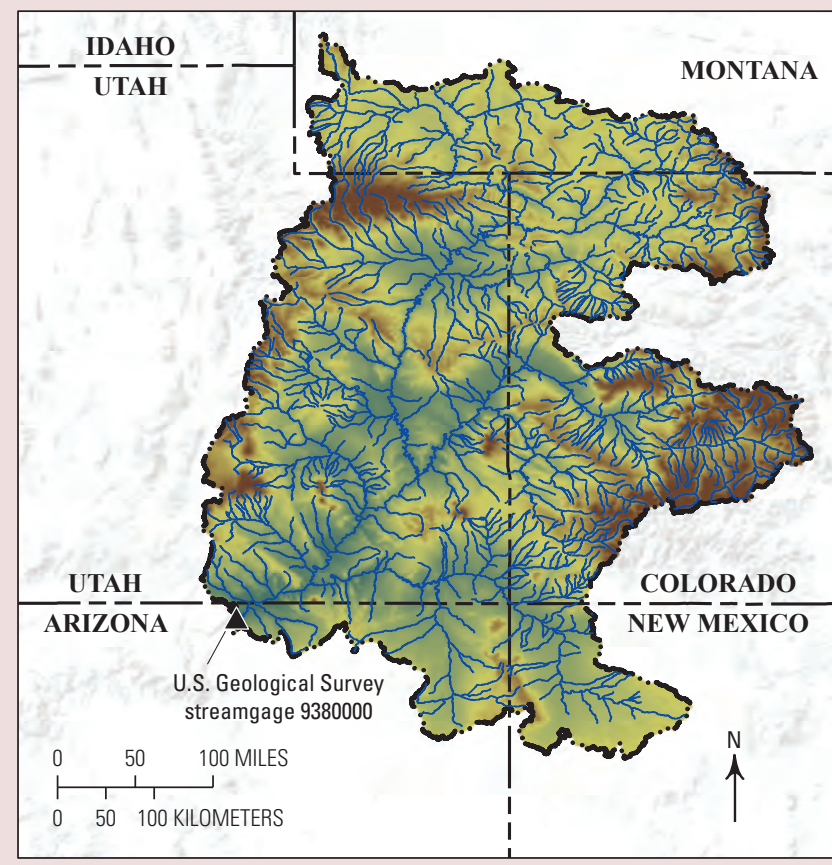

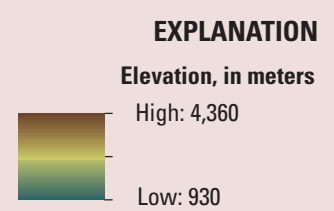

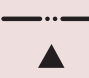

Hsed boundary

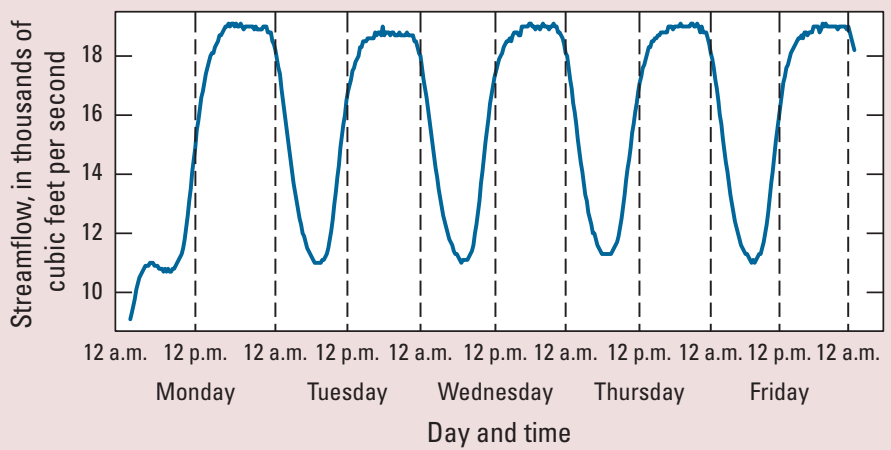




\section{Chapter F. Managing Modified Streamflows}

This chapter highlights strategies for managing modified streamflow. Changes in streamflow resulting from land use and water management affect social and ecological water uses (see chapters B-E). Actions to avoid or mitigate the effects of streamflow modification are important in many places to protect water uses. The goal of managing effects from streamflow modification depends on legal mandates and stakeholder concerns tempered by physical constraints of water availability, the natural setting such as the shape of the river valley, and infrastructure such as dams. Examples of goals include protecting or restoring ecosystem health; supporting a highly valued species; or simultaneously providing water for power generation, irrigation, and endangered species.

Key to effective management of streamflow modification is a scientific understanding of how ecosystems respond to changes in streamflow (see "Key Science Issues" sidebar). Management of modified low flows (magnitude, duration, frequency, and timing) is feasible in many places while maintaining other existing water uses and is likely to provide ecological benefits. In contrast, management of high flows is challenging because of the volume of water involved. For example, detaining urban runoff is not always feasible given limitations to infrastructure, and creating high flows through a dam results in lost reservoir storage, which could limit water availability for other uses. In addition, allowing rivers to experience high flows has implications for how people use land along floodplains. High-flow management depends on understanding ecological needs, the local river channel-floodplain context, and flood-related risks, but recent innovations suggest it is possible to manage high flows and balance these needs (DC Water, 2018).

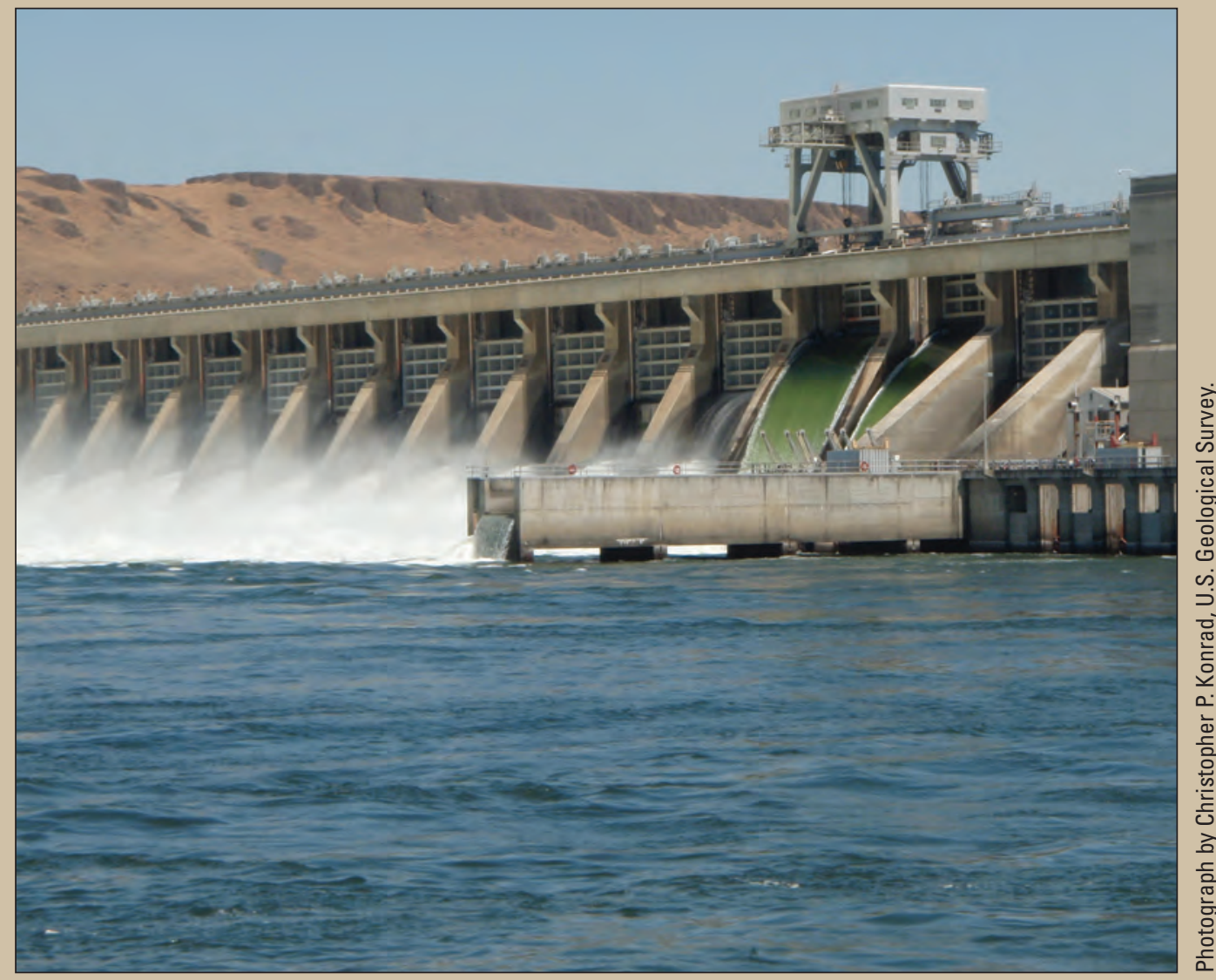

Changes in streamflow resulting from land use and water management affect water availability for social and ecological needs. Actions to avoid or mitigate the effects of streamflow modification are therefore important in many places to protect water uses. 


\section{Key Science Issues for Managing Streamflow Modification}

\section{What is the Natural Flow Regime?}

It is important to characterize the natural flow regime of a river before streamflow modification can be managed (Poff and others, 1997). Flow regimes are characterized by variation in discharge at multiple time scales related to sources of runoff, groundwater-surface water interactions, and climate variation. Many types of natural flow regimes exist across the United States because of differences in climate, topography, and basin size (Botter and others, 2013). Changes from natural variation can be difficult to identify especially because they may involve seasonal timing or frequency (Carlisle and others, 2011).

\section{Can a Natural Flow Regime be Adequately Characterized by a Limited Set of Streamflow Characteristics?}

Management is simplified when a limited set of streamflow attributes is used to represent the flow regime (for example, Archfield and others, 2014; Eng and others, 2017), but this practice may overlook some flow attributes that are critical for some uses. For example, species such as Populus fremontii S. Watson (cottonwood) have streamflow requirements throughout their life cycle, including the distribution and germination of seeds, establishment of saplings, and maintenance of mature forests (Merritt and others, 2010). Ecosystems include many components that have streamflow needs at a wide range of time scales (daily to centuries) (Konrad, 2012). In such cases, management objectives for streamflow may need to be dynamic - changing over time depending on uses and the flow history at a site (Nyatsanza and others, 2015). Management prescriptions that limit flow modification to a fixed percentage of streamflow at any time have been used as an alternative to prescribed flow metrics to maintain all components of a flow regime (Richter and others, 2011; McKay and others, 2016). Likewise, adaptive management can be used to evaluate if streamflow management based on a limited set of streamflow characteristics is effective and if additional characteristics should be considered (Melis and others, 2015).

\section{Will the Ecosystem Respond to Streamflow Management?}

The possibility of accommodating many different water uses in a river basin depends on narrowly defined streamflow requirements for each use that do not conflict with other users. A narrow definition of streamflow requirements that do not require protection or restoration of natural streamflow regimes for ecological uses may be necessary for solutions that serve multiple objectives, but the efficacy of streamflow management with such a limited scope has not been demonstrated in general (for example, Kiernan and others, 2012). Approaches that integrate the ecological effects of streamflow over time and account for effects of confounding factors such as temperature, sediment, or invasive species (for example, Gido and others, 2010; McKay and others, 2016) are important to identify the conditions when streamflow has the greatest ecological "utility" and, thus, how it can be managed efficiently for ecological benefit.

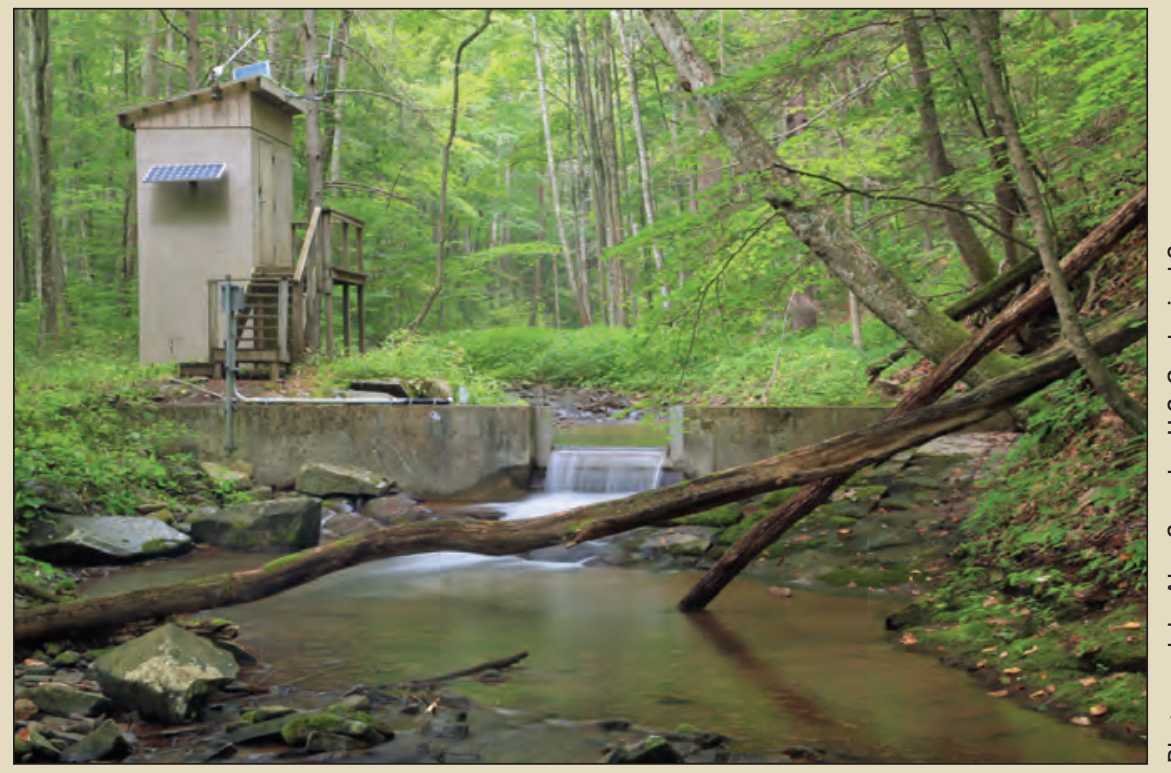

Understanding the natural characteristics of streamflow, and how they are influenced by climate and humans, requires long-term monitoring data such as that obtained from this U.S. Geological Survey streamgage in the Appalachian Mountains of Virginia. 


\section{Why Manage Modified Streamflows?}

Streamflow modification can harm other human uses of water, limit land use along river corridors, and impair ecosystem health. For example, diversions may limit the water available downstream for other water users and public resources (California Supreme Court, 1983). Stormwater runoff in urban areas can increase the frequency and extent of flooding (Konrad, 2003; National Research Council, 2008). Managing streamflow modification therefore protects people, their uses of water, and ecosystems.

Legal mandates for managing streamflow modification in the United States include Federal and State statutes, interstate compacts, and Federal, Tribal, and State water rights. The Wild and Scenic Rivers Act of 1968 (Public Law 90-542) calls for the preservation of free-flowing conditions. Management of streamflow modification may be necessary to achieve the purposes of other environmental laws, including the Endangered Species Act of 1973 (Public Law 93-205), the Clean Water Act (Public Law 92-500), and the National Environmental Policy Act (Public Law 91-190; Novak and others, 2016). Collectively, these legal mandates provide a means to mitigate or prevent streamflow modification from Federal actions such as the relicensing of hydropower dams, operation of Federal water projects, and construction of federally funded infrastructure.

Stakeholder concerns also motivate the management of streamflow modification to accommodate a wider range of water uses than would be possible when water is managed for a single purpose without regard for its effects (Richter and others, 2006; Kennedy and others, 2018). Operation of Glen Canyon Dam on the Colorado River upstream from the Grand Canyon, for example, must balance multiple objectives including power generation, water supply, recreation, cultural resources, and endangered species (Department of the Interior, 2016). In many rivers, a range of effects from streamflow modification must be addressed for more equitable and efficient water management.

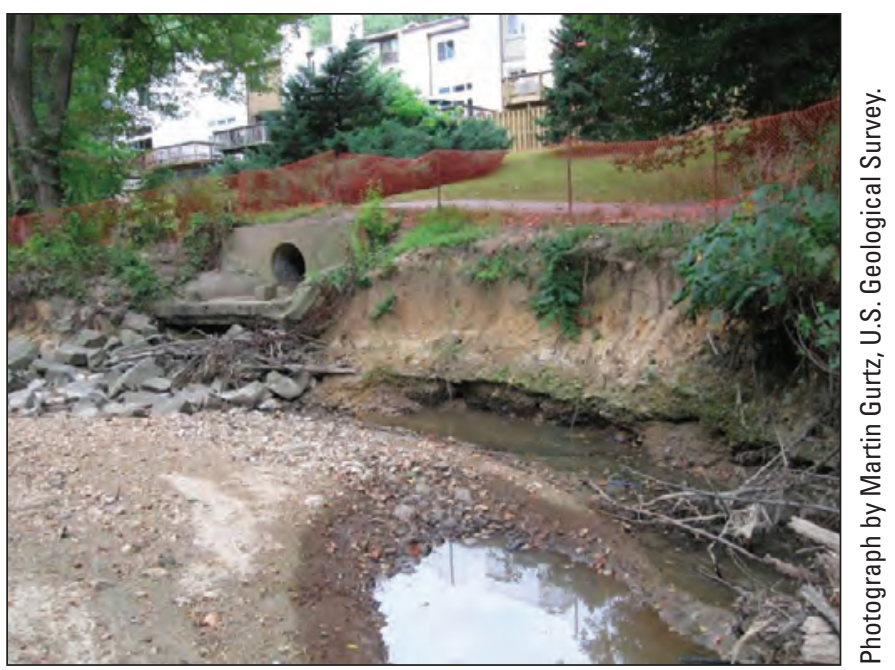

Without management efforts to mitigate high streamflows, stormwater runoff in urban areas has the potential to damage infrastructure and property and threaten public safety, as shown in this photograph of Snakeden Creek in Reston, Virginia, where erosion from uncontrolled stormwater runoff has damaged a storm drain and encroached on a hiking trail.

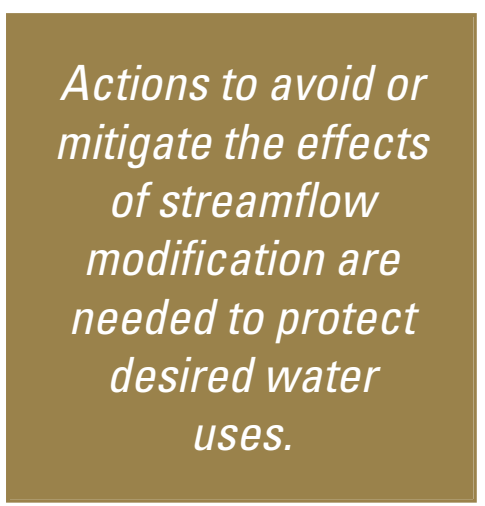




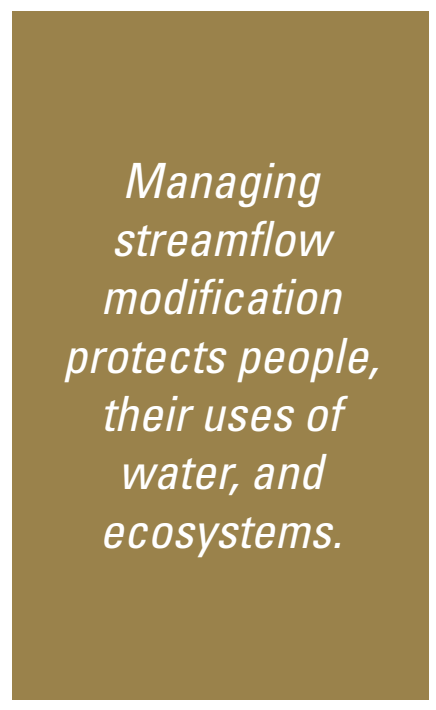

\section{Approaches for Managing Streamflow Modification}

Several approaches are used in the management of streamflow modification to fit stakeholder goals. The scope of management can be limited to key streamflow characteristics such as low-flow magnitude or can be more comprehensive by addressing the flow regime of a riverthe combination of streamflow magnitude, variability, and timing. Management focused on a specific streamflow characteristic typically targets promoting the survival of a species of interest. In contrast, management focused on the entire natural flow regime may be used to protect a broader array of ecological benefits. The four case studies that follow provide examples of different approaches for managing and mitigating the effects of modified streamflows.

Approach 1. Protect/restore multiple characteristics of natural streamflows (Trinity River case study).-This approach involves the protection of multiple characteristics, such as lowflow and high-flow magnitude, duration, and frequency. In its most comprehensive implementation, this approach strives to protect all characteristics of the natural flow regime. The premise of this approach is that natural characteristics of streamflow will sustain biological functioning of the widest array of species. This approach therefore requires little to no understanding of the specific streamflow characteristics required for ecological functioning.

Approach 2. Protect/restore specific characteristics of natural streamflows (Chesapeake Bay and Delaware River case studies).-This approach is based on the theory that certain streamflow characteristics (for example, high-flow duration) are necessary for ecosystem health or life stages of certain species. In this approach, the sensitivity of these outcomes to flow characteristics must be understood for effective management. A streamflow characteristic may serve as the standard to assess the performance of management actions (for example, low-flow magnitude), or a physical or biological outcome may be used in an adaptive management cycle, such as the following: manage flow characteristic - monitor outcome-revise flow management.

Approach 3. Manage streamflow for specific outcomes (Columbia River case study).-This approach represents active ecosystem management, which is typically required when other goals such as water supply or energy production are less flexible. Often, the specific management outcome is driven by specific needs, such as the life stage of an endangered species.

Approach 4. Manage other elements of the ecosystem to mitigate/compensate for effects of modified streamflow (Columbia River case study). - Like approach 3, this approach represents active ecosystem management, which is typically required when other goals such as water supply or energy production are less flexible. Conversely, this approach is based on a premise that other ecosystem elements, such as water quality or nonnative species, can compensate for the undesirable effects of modified streamflow. This approach requires a detailed understanding of the nature of the ecological effects of modified streamflows and knowledge of the design of actions that can benefit the ecosystem despite the constraints imposed by the needs of other water uses. The following four case studies provide examples of different approaches for managing and mitigating the effects of modified streamflows. 


\section{Reservoir Operations on the Trinity River were Modified to Restore More Natural Streamflows to Benefit Salmon Populations}

The Trinity River originates in the Trinity and Salmon Mountains of northern California and flows 160 miles through forested mountains before joining the Klamath River. The Trinity River is well known for its historic salmon runs that sustained the Hoopa Valley and Yurok Tribes. Construction of the Trinity Dam in the 1960s and the transfer of a substantial part of the basin's water to the Sacramento River Basin modified the natural streamflows of the Trinity River and contributed to a dramatic decline in salmon populations. In 2000, the Bureau of Reclamation reduced the transbasin diversions and adjusted reservoir operations to allow more natural seasonal variability of

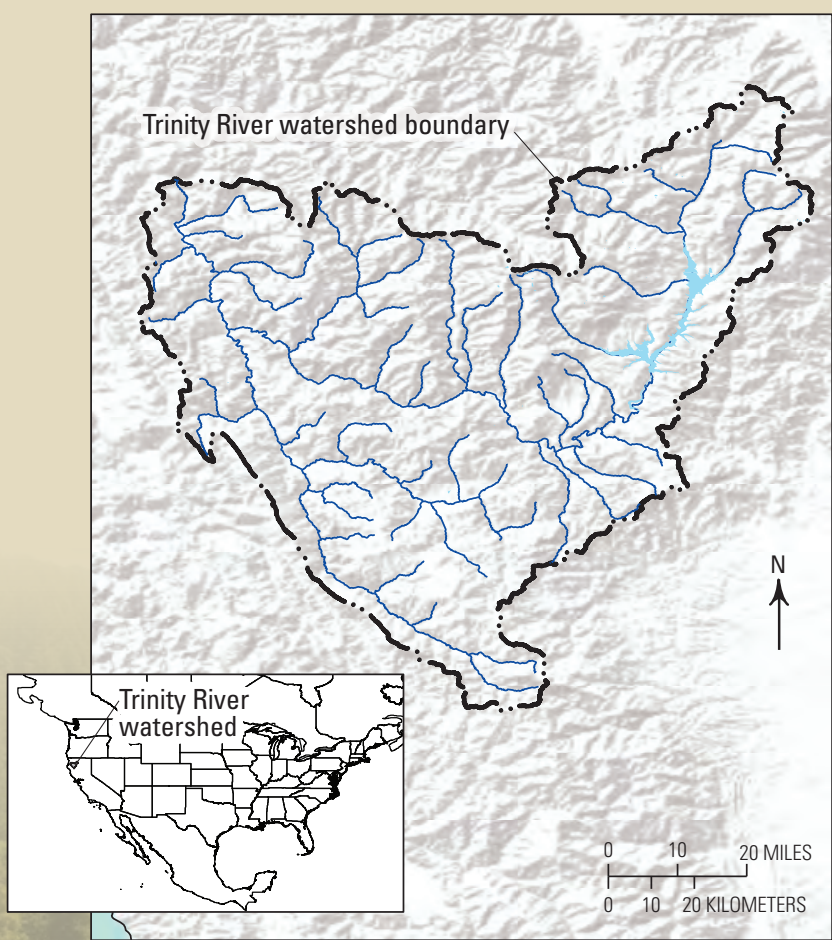

streamflow including high flows in spring (Department of the Interior, 2000). As shown below, streamflows downstream from the dam were typically highly modified before the adjustment, but were much closer to natural after reservoir management was adjusted. To make these management changes possible, a small percentage of stored water was reallocated from irrigation use to ecosystem restoration. The use of Trinity River water remains a contentious issue, especially during times of drought when it is particularly needed by irrigators and the ecosystem both.

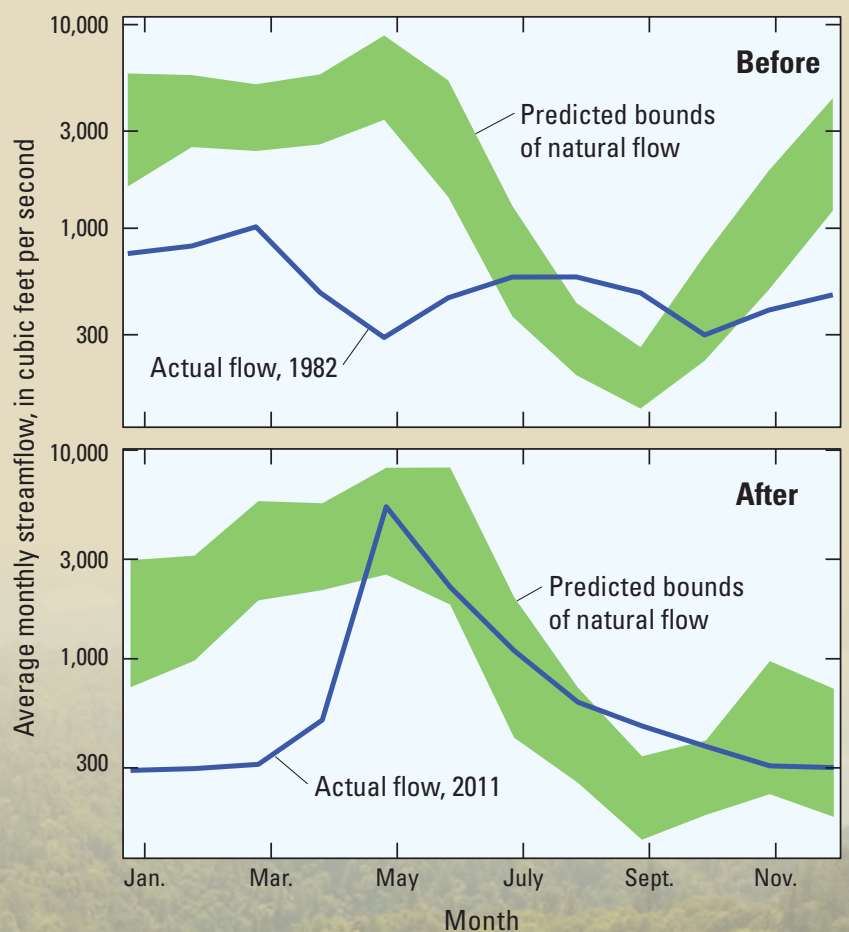

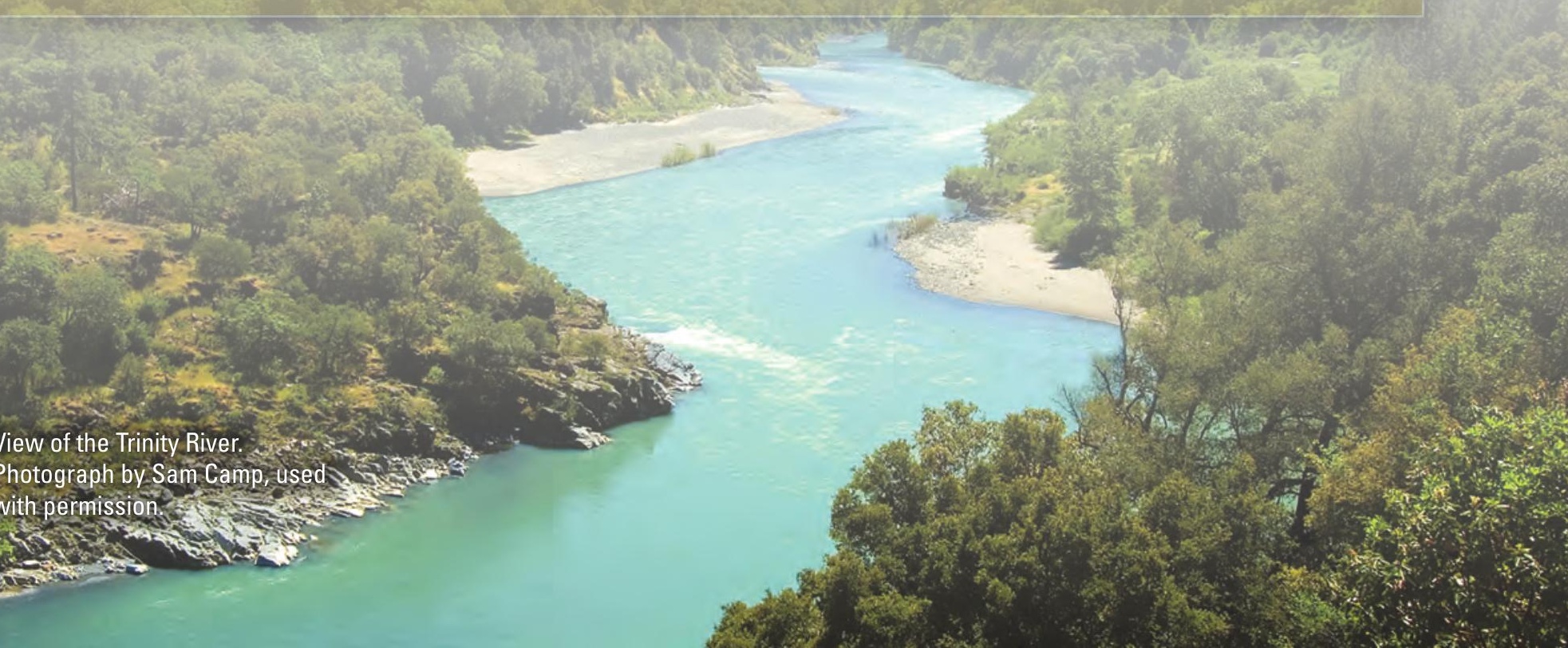




\section{Managing High Flows in the Chesapeake Bay Watershed is a Tool to Improve Water Quality}

America's largest estuary, the Chesapeake Bay, receives freshwater draining from more than 64,000 square miles of land. Much of the landscape has been converted from forests and pastures to buildings and roads to support more than 16 million people that live in the watershed. This conversion of land cover, along with gutters and other storm drainage systems, has increased the amount and rate of stormwater delivered to streams. This increases erosion of stream channels and delivers pollutants to streams and ultimately the bay. The States in the Chesapeake Bay watershed are working together to reduce stormwater in streams by upgrading municipal stormwater systems and promoting on-site management of stormwater through low-impact development.

Large parts of the Chesapeake Bay watershed have a high potential for additional urban growth (map inset). Without measures to manage excessive high flows caused by stormwater, societal goals to improve water quality and ecological health in the Chesapeake Bay and its receiving waters would be compromised by additional modification of streamflows.
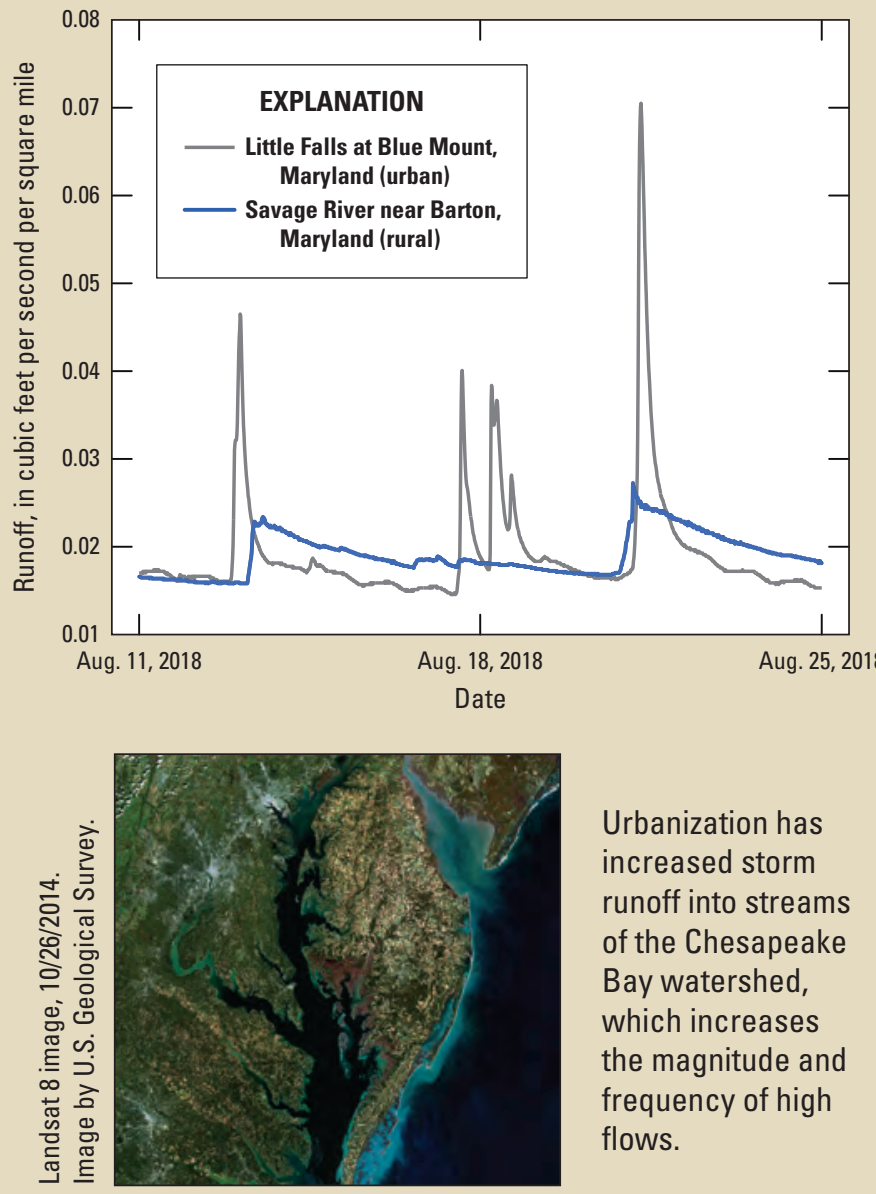

Urbanization has increased storm runoff into streams of the Chesapeake Bay watershed, which increases the magnitude and frequency of high flows.

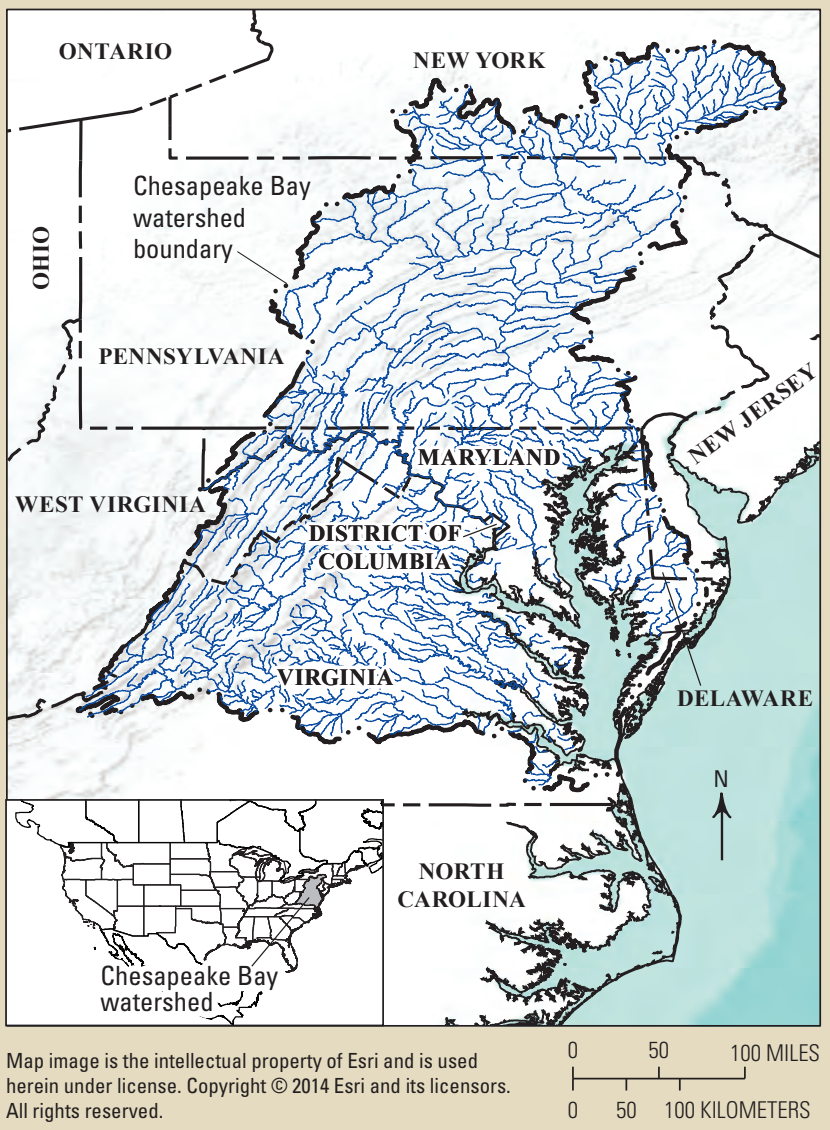

All rights reserved.

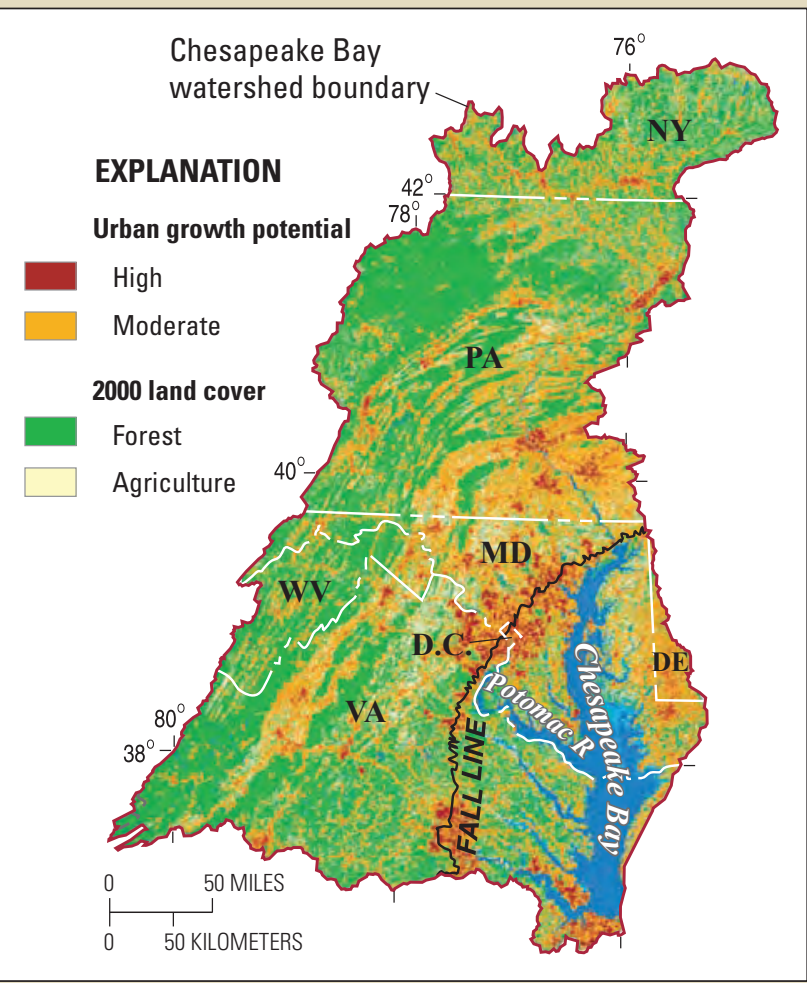




\section{Managing Low Flows in the Delaware River Protects Endangered Species and Improves Water Quality}

The Delaware River drains 13,500 square miles of the Appalachian Mountains of New York and Pennsylvania, as well as parts of Maryland, New Jersey, and Delaware. The river and its watershed are critical to the economic and ecological health of the area. More than 15 million people depend on the river for drinking water, and the river is home to the world's largest freshwater portwhich is a hub of economic activity in the region. The Delaware River also supports a rich diversity of fish and wildlife resources. The river was once home to millions of migratory fish, including the Acipenser oxyrinchus (Atlantic sturgeon) and Alosa sapidissima (American shad), but populations of these fish declined precipitously beginning in the 19th century because of poor water quality. Management actions to improve water quality and streamflows have contributed to rebounding populations of these fish in recent decades (U.S. Fish and Wildlife Service, 2018).

Streamflows in the Delaware are affected by three reservoirs. Since 2007, the reservoirs have been managed to provide the flexibility needed to address many downstream water uses, including flood mitigation, water supply, fish and wildlife habitat, and estuary health.

The river supports an endangered species of freshwater mussel known as Alasmidonta heterodon (dwarf wedgemussel; inset photograph). Mussels serve an

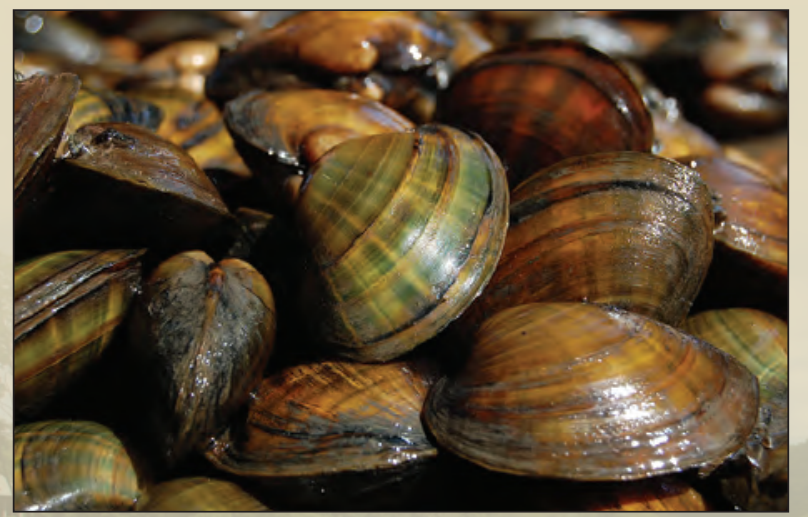

important role in the ecosystem because they feed by continuously filtering water, removing particles and thereby improving water clarity. Because mussels are mostly sedentary, they are susceptible to rapid changes in flow and, in particular, being stranded when flows are extremely low. One strategic management goal in the Delaware River is to manage flows and land use to maintain adequate low-flow magnitudes for the mussels and other aquatic species (Maloney and others, 2012).

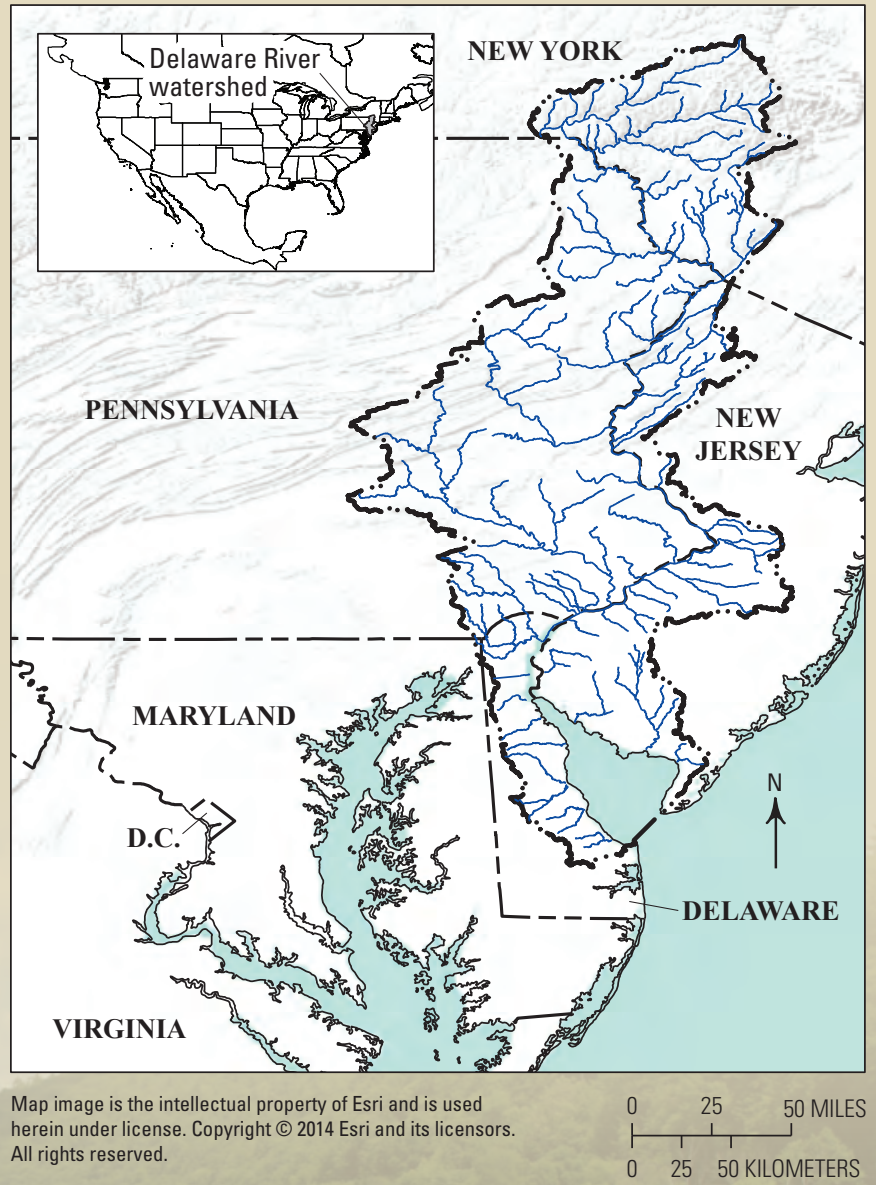

Chesapeake Bay mussels.

View of the Delaware River.

Photograph by National Park Service. 


\section{Dam Modification and Barging Used to Maintain Salmon Populations in the Columbia River}

The Columbia River flows from the Rocky Mountains in Canada and the United States to the Pacific Ocean. Its abundant water and steep descent from its headwaters are ideal for many types of salmon and for generating electricity. Most of the main stem of the Columbia River in the United States is impounded by dams that form a series of reservoirs with slow-moving water. Juvenile salmon, which rely on the strong current of the free-flowing river to carry them to the Pacific Ocean, struggle to swim through the reservoirs, which also contain nonnative predatory fish. To improve the survival of juvenile salmon, water managers including Bonneville Power Administration and U.S. Army Corps of Engineers release water through surface spillways in dams to flush juvenile salmon downstream. This program has required modifying spillways and their operation. Barges also are used to transport hatchery-raised, juvenile salmon downstream to avoid the reservoirs.

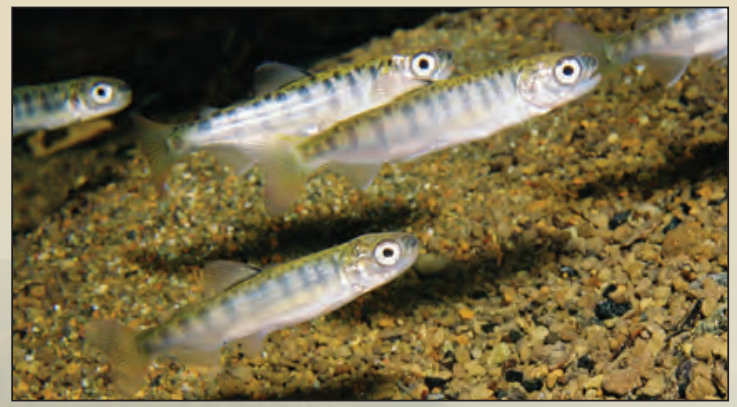

Juvenile Chinook salmon.

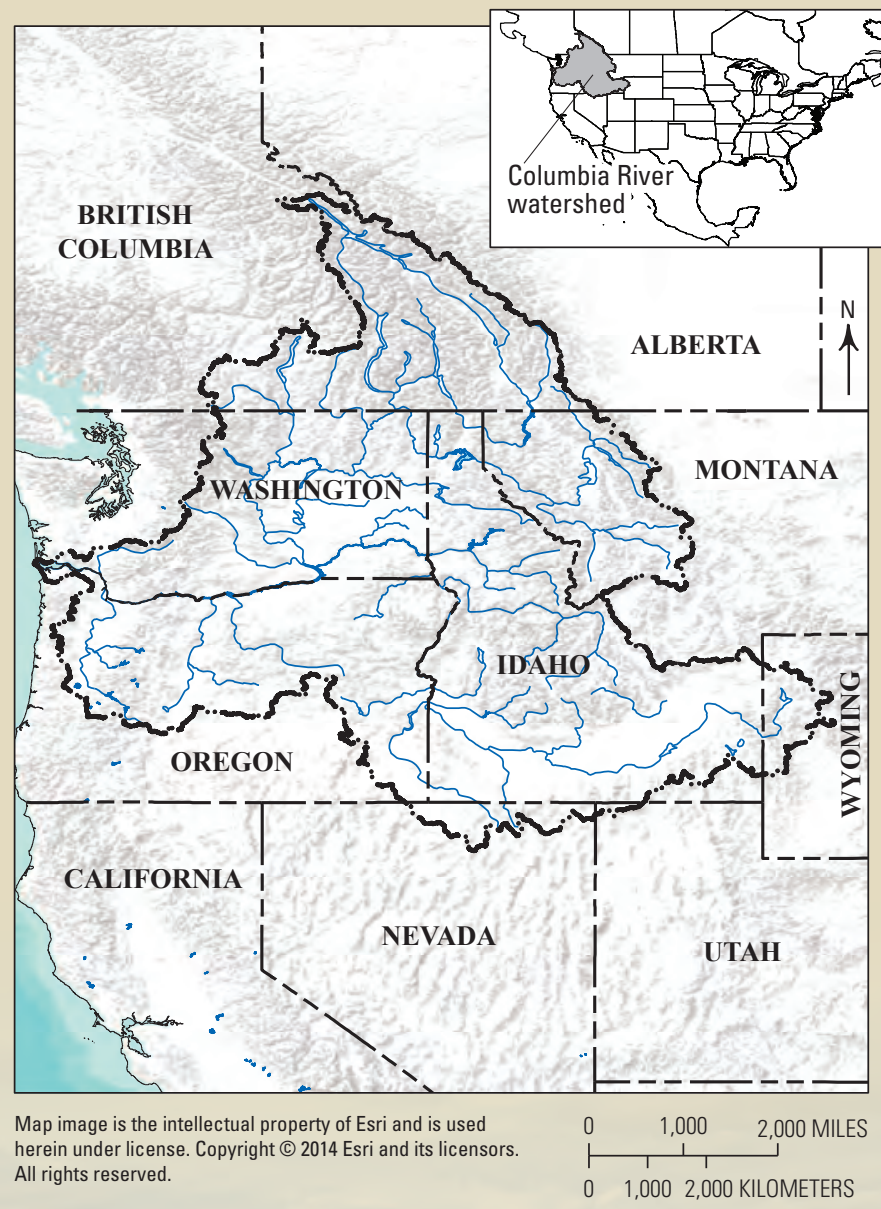

Aerial view of the Columbia River.

Photograph by Kevin Wingert, Bonneville Power Administration. 


\section{References Cited}

Archfield, S.A., Kennen, J.G., Carlisle, D.M., and Wolock, D.M., 2014, An objective and parsimonious approach for classifying natural flow regimes at a continental scale: River Research and Applications, v. 30, no. 9, p. 1166-1183. [Also available at https://doi.org/10.1002/rra.2710.]

Bear River Water Quality Committee of the Bear River Commission, 2017, Welcome to the Bear River Watershed Information System: Bear River Watershed Information System database, accessed March 2019 at http://bearriverinfo.org/ index.

Bogan, M.T., and Lytle, D.A., 2007, Seasonal flow variation allows "time-sharing" by disparate aquatic insect communities in montane desert streams: Freshwater Biology, v. 52, no. 2, p. 290-304. [Also available at https://doi.org/10.1111/ j.1365-2427.2006.01691.x.]

Bonneau, J., Fletcher, T., Costelloe, J., and Burns, M., 2017, Stormwater infiltration and the 'urban karst'-A review: Journal of Hydrology, v. 552, p. 141-150. [Also available at https://doi.org/10.1016/j.jhydrol.2017.06.043.]

Botter, G., Basso, S., Rodriguez-Iturbe, I., and Rinaldo, A., 2013, Resilience of river flow regimes: Proceedings of the National Academy of Sciences of the United States of America, v. 110, no. 32, p. 12925-12930. [Also available at https://doi.org/10.1073/pnas.1311920110.]

Bunn, S.E., and Arthington, A.H., 2002, Basic principles and ecological consequences of altered flow regimes for aquatic biodiversity: Environmental Management, v. 30, no. 4, p. 492-507. [Also available at https://doi.org/10.1007/ s00267-002-2737-0.]

California Supreme Court, 1983, National Audubon Society et al. v. The Superior Court of Alpine County, Department of Water and Power of the City of Los Angeles et al., 33 Cal. 3d 419, S.F. no. 24368.

Carlisle, D.M., Eng, K., Grantham, T.E., and Wolock, D.M., 2019, Regional-scale associations between indicators of biological integrity and indicators of streamflow modification: U.S. Geological Survey Open-File Report 2019-1088, 10 p., accessed September 2019 at https://doi.org/10.3133/ ofr20191088.

Carlisle, D.M., Grantham, T.E., Eng, K., and Wolock, D.M., 2017, Biological relevance of streamflow metrics-Regional and national perspectives: Freshwater Science, v. 36, no. 4, p. 927-940. [Also available at https://doi.org/10.1086/694913.]
Carlisle, D.M., Nelson, S.M., and May, J.T., 2015, Associations of stream health with altered flow and water temperature in the Sierra Nevada, California: Ecohydrology, v. 9, no. 6 , p. 930-941.

Carlisle, D.M., Wolock, D.M., and Meador, M.R., 2011, Alteration of streamflow magnitudes and potential ecological consequences - A multiregional assessment: Frontiers in Ecology and the Environment, v. 9, no. 5, p. 264-270. [Also available at https://doi.org/10.1890/100053.]

Colorado Parks and Wildlife, 2012, Natural areas information: Colorado Parks and Wildlife web page, accessed November 2018 at https:/cpw.state.co.us/aboutus/Pages/CNAP-Info. aspx.

DC Water, 2018, DC Water moves forward with planning to dramatically improve the health of the Potomac: DC Water web page, accessed November 2018 at https:/www.dcwater.com/whats-going-on/news/dc-watermoves-forward-planning-dramatically-improve-healthpotomac.

Department of the Interior, 2000, Record of decision for the Trinity River Mainstem Fishery Restoration Final Environmental Impact Statement: U.S. Department of the Interior, 43 p., accessed May 10, 2019, at http://www.trrp.net/ DataPort/doc.php?id=227.

Department of the Interior, 2016, Record of decision for the Glen Canyon Dam Long-Term Experimental and Management Plan Final Environmental Impact Statement: U.S. Department of the Interior, Bureau of Reclamation, and National Park Service, 196 p., accessed September 7, 2018, at http://ltempeis.anl.gov/documents/docs/LTEMP_ROD. pdf.

Dewson, Z.S., James, A.B.W., and Death, R.G., 2007, A review of the consequences of decreased flow for instream habitat and macroinvertebrates: Journal of the North American Benthological Society, v. 26, no. 3, p. 401-415. [Also available at https://doi.org/10.1899/06-110.1.]

Dieterich, M., and Anderson, N.H., 2000, The invertebrate fauna of summer-dry streams in western Oregon: Archiv für Hydrobiologie, v. 147, no. 3, p. 273-295. [Also available at https://doi.org/10.1127/archiv-hydrobiol/147/2000/273.]

Eng, K., Carlisle, D.M., Wolock, D.M., and Falcone, J.A., 2013, Predicting the likelihood of altered streamflows at ungauged rivers across the conterminous United States: River Research and Applications, v. 29, no. 6, p. 781-791. [Also available at https://doi.org/10.1002/rra.2565.]

Eng, K., Grantham, T.E., Carlisle, D.M., and Wolock, D.M., 2017, Predictability and selection of hydrologic metrics in riverine ecohydrology: Freshwater Science, v. 36, no. 4, p. 915-926. [Also available at https://doi.org/10.1086/694912.] 
Eng, K., Carlisle, D.M., Grantham, T.E., Wolock, D.M., and Eng, R.L., 2019, Severity and extent of alterations to natural streamflow regimes based on hydrologic metrics in the conterminous United States, 1980-2014: U.S. Geological Survey Scientific Investigations Report 2019-5001, 25 p. [Also available at https://doi.org/10.3133/sir20195001.]

Falke, J.A., Fausch, K.D., Bestgen, K.R., and Bailey, L.L., 2010, Spawning phenology and habitat use in a Great Plains, USA, stream fish assemblage - An occupancy estimation approach: Canadian Journal of Fisheries and Aquatic Sciences, v. 67, no. 12, p. 1942-1956. [Also available at https://doi.org/10.1139/F10-109.]

Finn, M.A., Boulton, A.J., and Chessman, B.C., 2009, Ecological responses to artificial drought in two Australian rivers with differing water extraction: Fundamental and Applied Limnology, v. 175, no. 3, p. 231-248. [Also available at https://doi.org/10.1127/1863-9135/2009/0175-0231.]

Freeman, M.C., Bowen, Z.H., Bovee, K.D., and Irwin, E.R., 2001, Flow and habitat effects on juvenile fish abundance in natural and altered flow regimes: Ecological Applications, v. 11, no. 1, p. 179-190. [Also available at https://doi.org/10.1890/1051-0761(2001)011[0179:FAHEO $\mathrm{J}] 2.0 . \mathrm{CO} ; 2$.

Gido, K.B., Dodds, W.K., and Eberle, M.E., 2010, Retrospective analysis of fish community change during a halfcentury of landuse and streamflow changes: Journal of the North American Benthological Society, v. 29, no. 3, p. 970987. [Also available at https://doi.org/10.1899/09-116.1.]

Graf, W.L., 2006, Downstream hydrologic and geomorphic effects of large dams on American rivers: Geomorphology, v. 79, nos. 3-4, p. 336-360. [Also available at https://doi.org/10.1016/j.geomorph.2006.06.022.]

Grantham, T.E., Newburn, D.A., McCarthy, M.A., and Merenlender, A.M., 2012, The role of streamflow and land use in limiting oversummer survival of juvenile steelhead in California streams: Transactions of the American Fisheries Society, v. 141, no. 3, p. 585-598. [Also available at https://doi.org/10.1080/00028487.2012.683472.]

Grimm, N.B., Chapin, F.S., Bierwagen, B., Gonzalez, P., Groffman, P.M., Luo, Y.Q., Melton, F., Nadelhoffer, K., Pairis, A., Raymond, P.A., Schimel, J., and Williamson, C.E., 2013, The impacts of climate change on ecosystem structure and function: Frontiers in Ecology and the Environment, v. 11, p. 474-482.[Also available at https://doi.org/10.1890/120282.]

Henry's Fork Foundation, 2014, Henry's Fork Foundation: Henry's Fork Foundation web page, accessed January 2019 at https://henrysfork.org/.
Hopkins, K.G., Morse, N.B., Bain, D.J., Bettez, N.D., Grimm, N.B., Morse, J.L., Palta, M.M., Shuster, W.D., Bratt, A.R., and Suchy, A.K., 2015, Assessment of regional variation in streamflow responses to urbanization and the persistence of physiography: Environmental Science \& Technology, v. 49, no. 5, p. 2724-2732. [Also available at https://doi.org/10.1021/es505389y.]

James, A.B.W., and Suren, A.M., 2009, The response of invertebrates to a gradient of flow reduction-An instream channel study in a New Zealand lowland river: Freshwater Biology, v. 54, p. 2225-2242. [Also available at https://doi.org/10.1111/j.1365-2427.2009.02254.x.]

Juracek, K., 2014, The aging of America's reservoirs - Inreservoir and downstream physical changes and habitat implications: Journal of the American Water Resources Association, v. 151, no. 1, p. 168-184. [Also available at https://doi.org/10.1111/jawr.12238.]

Kennedy, T.A., Muehlbauer, J.D., Yackulic, C.B., Lytle, D.A., Miller, S.W., Dibble, K.L., Kortenhoeven, E.W., Metcalfe, A.N., and Baxter, C.V., 2016, Flow management for hydropower extirpates aquatic insects, undermining river food webs: Bioscience, v. 66, no. 7, p. 561-575. [Also available at https://doi.org/10.1093/biosci/biw059.]

Kennedy, K., Lutz, K., Hatfield, C., Martin, L., Barker, T., Palmer, R., Detwiler, L., Anleitner, J., and Hickey, J., 2018, The Connecticut River flow restoration study - A watershed-scale assessment of the potential for flow restoration through dam re-operation: Northampton, Mass., The Nature Conservancy, U.S. Army Corps of Engineers, and University of Massachusetts, Amherst, 62 p. [Also available at https://tnc.app.box.com/s/jdnxvgsquxcqhbcpcro92qhxb6wb c4td/file/294321142454.]

Kiernan, J.D., Moyle, P.B., and Crain, P.K., 2012, Restoring native fish assemblages to a regulated California stream using the natural flow regime concept: Ecological Applications, v. 22, no. 5, p. 1472-1482. [Also available at https://doi.org/10.1890/11-0480.1.]

Knight, R.R., Murphy, J.C., Wolfe, W.J., Saylor, C.F., and Wales, A.K., 2014, Ecological limit functions relating fish community response to hydrologic departures of the ecological flow regime in the Tennessee River basin, United States: Ecohydrology, v. 7, p. 1262-1280. [Also available at https://doi.org/10.1002/eco.1460.]

Konrad, C.P., 2003, Effects of urban development on floods: U.S. Geological Survey Fact Sheet 076-03, 4 p. [Also available at https://doi.org/10.3133/fs07603.]

Konrad, C.P., Warner, A., and Higgins, J.V., 2012, Evaluating dam re-operation for freshwater conservation in the Sustainable Rivers Project: River Research and Applications, v. 28, no. 6, p. 777-792. [Also available at https://doi.org/10.1002/rra.1524.] 
Kupferberg, S.J., Palen, W.J., Lind, A.J., Bobzien, S., Catenazzi, A., Drennan, J., and Power, M.E., 2012, Effects of flow regimes altered by dams on survival, population declines, and range-wide losses of California river-breeding frogs: Conservation Biology, v. 26, no. 3, p. 513-524. [Also available at https://doi.org/10.1111/j.15231739.2012.01837.x.]

Macklin, M.G., and Lewin, J., 2015, The rivers of civilization: Quaternary Science Reviews, v. 114, p. 228-244. [Also available at https://doi.org/10.1016/j. quascirev.2015.02.004.]

Maloney, K.O., Lellis, W.A., Bennett, R.M., and Waddle, T.J., 2012, Habitat persistence for sedentary organisms in managed rivers - The case for the federally endangered dwarf wedgemussel (Alasmidonta heterodon) in the Delaware River: Freshwater Biology, v. 57, no. 6, p. 1315-1327. [Also available at https://doi.org/10.1111/j.13652427.2012.02788.x.]

McCabe, G.J., and Clark, M.P., 2005, Trends and variability in snowmelt runoff in the western United States: Journal of Hydrometeorology, v. 6, no. 4, p. 476-482. [Also available at https://doi.org/10.1175/JHM428.1.]

McKay, S.K., Freeman, M.C., and Covich, A.P., 2016, Application of effective discharge analysis to environmental flow decision-making: Environmental Management, v. 57, no. 6, p. 1153-1165. [Also available at https://doi.org/10.1007/ s00267-016-0684-4.]

Melcher, A.H., Bakken, T.H., Friedrich, T., Greimel, F., Humer, N., Schmutz, S., Zeiringer, B., and Webb, J.A., 2017, Drawing together multiple lines of evidence from assessment studies of hydropeaking pressures in impacted rivers: Freshwater Science, v. 36, no. 1, p. 220-230. [Also available at https://doi.org/10.1086/690295.]

Melis, T.S., Walters, C.J., and Korman, J., 2015, Surprise and opportunity for learning in Grand Canyon-The Glen Canyon Dam Adaptive Management Program: Ecology and Society, v. 20, no. 3, art. 22. [Also available at https://doi.org/10.5751/ES-07621-200322.]

Merritt, D.M., and Poff, N.L., 2010, Shifting dominance of riparian Populus and Tamarix along gradients of flow alteration in western North American rivers: Ecological Applications, v. 20, no. 1, p. 135-152. [Also available at https://doi.org/10.1890/08-2251.1.]

Merritt, D.M., Scott, M.L., Poff, N.L., Auble, G.T., and Lytle, D.A., 2010, Theory, methods and tools for determining environmental flows for riparian vegetation-Riparian vegetation-flow response guilds: Freshwater Biology, v. 55, no. 1, p. 206-225. [Also available at https://doi.org/10.1111/ j.1365-2427.2009.02206.x.]
Miller, S.W., Wooster, D., and Li, J., 2007, Resistance and resilience of macroinvertebrates to irrigation water withdrawals: Freshwater Biology, v. 52, no. 12, p. 24942510. [Also available at https://doi.org/10.1111/j.13652427.2007.01850.x.]

Naiman, R.J., Latterell, J.J., Pettit, N.E., and Olden, J.D., 2008 , Flow variability and the biophysical vitality of river systems: Comptes Rendus Geoscience, v. 340, nos. 9-10, p. 629-643. [Also available at https://doi.org/10.1016/j. crte.2008.01.002.]

National Research Council, 2008, Urban stormwater management in the United States: Washington, D.C., The National Academies Press, 529 p.

Novak, R., Kennen, J.G., Abele, R.W., Baschon, C.F., Carlisle, D.M., Dlugolecki, L., Eignor, D.M., Flotemersch, J.E., Ford, P., Fowler, J., Galer, R., Gordon, L.P., Hansen, S.E., Herbold, B., Johnson, T.E., Johnston, J.M., Konrad, C.P., Leamond, B., and Seelbach, P.W, 2016, Final EPA-USGS technical report-Protecting aquatic life from effects of hydrologic alteration: U.S. Geological Survey Scientific Investigations Report 2016-5164, EPA Report 822-R-156-007, 156 p., accessed December 2018 at https://www.epa.gov/sites/production/files/2016-12/ documents/final-aquatic-life-hydrologic-alteration-report. pdf.

Nyatsanza, F.F., Graas, S., and van der Zaag, P., 2015, The impact of dynamic environmental flow releases on hydropower production in the Zambezi River basin: Journal of the American Water Resources Association, v. 51, no. 4, p. 1029-1042. [Also available at https://doi.org/10.1111/ jawr.12280.]

Olden, J.D., Konrad, C.P., Melis, T.S., Kennard, M.J., Freeman, M.C., Mims, M.C., Bray, E.N., Gido, K.B., Hemphill, N.P., Lytle, D.A., McMullen, L.E., Pyron, M., Robinson, C.T., Schmidt, J.C., and Williams, J.G., 2014, Are largescale flow experiments informing the science and management of freshwater ecosystems?: Frontiers in Ecology and the Environment, v. 12, no. 3, p. 176-185. [Also available at https://doi.org/10.1890/130076.]

Palmer, M.A., Lettenmaier, D.P., Poff, N.L., Postel, S.L., Richter, B., and Warner, R., 2009, Climate change and river ecosystems - Protection and adaptation options: Environmental Management, v. 44, no. 6, p. 1053-1068. [Also available at https://doi.org/10.1007/s00267-009-9329-1.]

Peckarsky, B.L., Taylor, B.W., and Caudill, C.C., 2000, Hydrologic and behavioral constraints on oviposition of stream insects - Implications for adult dispersal: Oecologia, v. 125, no. 2, p. 186-200. [Also available at https://doi. org/10.1007/s004420000446.] 
Perkin, J.S., Gido, K.B., Falke, J.A., Fausch, K.D., Crockett, H., Johnson, E.R., and Sanderson, J., 2017, Groundwater declines are linked to changes in Great Plains stream fish assemblages: Proceedings of the National Academy of Sciences of the United States of America, v. 114, no. 28, p. 7373-7378. [Also available at https://doi.org/10.1073/ pnas.1618936114.]

Phillips, S.W., ed., 2007, Synthesis of U.S. Geological Survey science for the Chesapeake Bay ecosystem and implications for environmental management: U.S. Geological Survey Circular 1316, 63 p. [Also available at https://pubs.usgs.gov/circ/circ1316/circular1316.pdf.]

Poff, N.L., Allan, J.D., Bain, M.B., Karr, J.R., Prestegaard, K.L., Richter, B.D., Sparks, R.E., and Stromberg, J.C., 1997, The natural flow regime: Bioscience, v. 47, no. 11, p. 769-784. [Also available at https://doi.org/10.2307/1313099.]

Poff, N.L., Bledsoe, B.P., and Cuhaciyan, C.O., 2006, Hydrologic variation with land use across the contiguous United States-Geomorphic and ecological consequences for stream ecosystems: Geomorphology, v. 79, nos. 3-4, p. 264-285. [Also available at https://doi.org/10.1016/j. geomorph.2006.06.032.]

Poff, N. L., Olden, J.D., Merritt, D.M., and Pepin, D.M., 2007, Homogenization of regional river dynamics by dams and global biodiversity implications: Proceedings of the National Academy of Sciences of the United States of America, v. 104, p. 5732-5737. [Also available at https://www.pnas.org/content/104/14/5732.]

Poshtiri, P.M., and Pal, I., 2016, Patterns of hydrological drought indicators in major US River basins: Climate Change, v. 134, p. 549-563.

Rice, J., and Westerhoff, P., 2017, High levels of endocrine pollutants in US streams during low flow due to insufficient wastewater dilution: Nature Geoscience, v. 10, p. 587-591.

Richter, B.D., Davis, M.M., Apse, C., and Konrad, C., 2011, A presumptive standard for environmental flow protection: River Research and Application, v. 28, no. 8, p. 1312-1321. [Also available at https://doi.org/10.1002/rra.1511.]

Richter, B.D., Warner, A.T., Meyer, J.L., and Lutz, K., 2006, A collaborative and adaptive process for developing environmental flow recommendations: River Research and Applications, v. 22, no. 3, p. 297-318. [Also available at https://doi.org/10.1002/rra.892.]

Rolls, R.J., Leigh, C., and Sheldon, F., 2012, Mechanistic effects of low-flow hydrology on riverine ecosystems-Ecological principles and consequences of alteration: Freshwater Science, v. 31, no. 4, p. 1163-1186. [Also available at https://doi.org/10.1899/12-002.1.]
Rood, S.B., Pan, J., Gill, K.M., Franks, C.G., Samuelson, G.M., and Shepherd, S., 2008, Declining summer flows of Rocky Mountain rivers - Changing seasonal hydrology and probable impacts on floodplain forests: Journal of Hydrology, v. 349, no. 3-4, p. 397-410. [Also available at https://doi.org/10.1016/j.jhydrol.2007.11.012.]

Stewart, I.T., Cayan, D.R., and Dettinger, M.D., 2004, Changes in snowmelt runoff timing in western North America under a 'business as usual' climate scenario: Climatic Change, v. 62, no. 1-3, p. 217-232. [Also available at https://doi.org/10.1023/B:CLIM.0000013702.22656.e8.]

Tockner, K., Malard, F., and Ward, J.V., 2000, An extension of the flood pulse concept: Hydrological Processes, v. 14, nos. 16-17, p. 2861-2883. [Also available at https://doi.org/10.1002/1099-1085(200011/12)14:16/17<28 61::AID-HYP124>3.0.CO;2-F.]

U.S. Fish and Wildlife Service, 2018, Restoring the Delaware River Basin: U.S. Fish and Wildlife Service web page, accessed August 2018 at https://www.fws.gov/northeast/ delawareriver/delaware-river-basin-conservation-act.html.

Vieira, N.K.M., Poff, N.L., Carlisle, D.M., Moulton, S.R., II, Koski, M.L., and Kondratieff, B.C., 2006, A database of lotic invertebrate traits for North America: U.S. Geological Survey Data Series 187, 19 p.

Walsh, C.J., Roy, A.H., Feminella, J.W., Cottingham, P.D., Groffman, P.M., and Morgan, R.P., II, 2005, The urban stream syndrome-Current knowledge and the search for a cure: Journal of the North American Benthological Society, v. 24, no. 3, p. 706-723. [Also available at https://doi.org/10.1899/04-028.1.]

Warren, M., Dunbar, M.J., and Smith, C., 2015, River flow as a determinant of salmonid distribution and abundanceA review: Environmental Biology of Fishes, v. 98, no. 6, p. 1695-1717. [Also available at https://doi.org/10.1007/ s10641-015-0376-6.]

Webb, J.A., Miller, K.A., King, E.L., Little, S.C. de, Stewardson, M.J., Zimmerman, J.K.H., and Poff, N.L., 2013, Squeezing the most out of existing literature - A systematic re-analysis of published evidence on ecological responses to altered flows: Freshwater Biology, v. 58, no. 12, p. 24392451. [Also available at https://doi.org/10.1111/fwb.12234.]

Wootton, R.J., and Smith, C., 2015, Reproductive biology of teleost fishes: Oxford, Wiley-Blackwell, 463 p.

Yarnell, S.M., Petts, G.E., Schmidt, J.C., Whipple, A.A., Beller, E.E., Dahm, C.N., Goodwin, P., and Viers, J.H., 2015, Functional flows in modified riverscapes-Hydrographs, habitats and opportunities: BioScience, v. 65, no. 10, p. 963-972. [Also available at https://doi.org/10.1093/biosci/biv102.] 
For additional information, contact:

NAWQA Science Team

(gs-w_opp_nawqa_science_team@usgs.gov)

U.S. Geological Survey

12201 Sunrise Valley Drive

Reston, VA 20192

https://water.usgs.gov/nawqa/

Publishing support provided by the

Rolla Publishing Service Center 

$20+2 x^{2}+2 x-2$
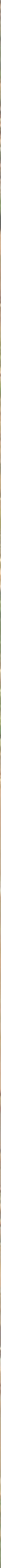